Internal Mammary Artery Perforator flap

Pascal P.A. Schellekens 


\section{Internal Mammary Artery Perforator flap}

(c) P.P.A.Schellekens 2012

$\begin{array}{ll}\text { Lay-out } & \text { Nicole Nijhuis - Gildeprint Drukkerijen } \\ \text { Cover Design } & \text { Pascal Schellekens en Thomas Dobber } \\ \text { Illustraties } & \text { Ingrid Janssen } \\ \text { Print } & \text { Gildeprint Drukkerijen, Enschede } \\ \text { ISBN } & 978-90-393-5814-6\end{array}$




\title{
Internal Mammary Artery Perforator flap
}

\author{
Perforatorlap van de arteria mammaria interna \\ (met samenvatting in het Nederlands)
}

\section{Proefschrift}

Ter verkrijging van de graad van doctor aan de Universiteit Utrecht op gezag van de rector magnificus, prof. Dr. G.J. van der Zwaan in volge het besluit van het college voor promoties in het openbaar te verdedigen op

dinsdag 11 september 2012 des middags te 4.15 uur

door

Pascal Pieter Albertus Schellekens

geboren op 9 maart 1962 te Eindhoven 
Promotor

Copromotor
Prof. Dr. M. Kon

Dr. J.J. Hage

This thesis was financially supported by:

Afdeling Plastische, Reconstructieve en Handchirurgie UMC Utrecht,

Esthetisch Medisch Centrum Bosch en Duin

Raadgevers Kuijkhoven

J.E. Jurriaanse Stichting

Barbara en René Stokvis

Aleamed

Verenigd Accountantskantoor voor Medici en Paramedici

Bloomedical

Handen Centrum Utrecht

Allergan

Emdaplast

Qua Medical

Laprolan

BAP medical

$\mathrm{KCl}$

Carl Zeiss

Surgical Concepts

Oudshoorn

Pfizer

Chipsoft

Q-Med

MediMast

Krijnen Medical Innovations 
Geef mij de moed

om te veranderen

wat veranderd moet worden,

Geef mij de deemoed

om te aanvaarden

wat niet veranderd kan worden,

Geeft mij de wijsheid

om het verschil te zien

tussen beide.

Voor Julia, Stijn en Tijmen

Voor Ellen

Ter nagedachtenis aan mijn moeder 
Paranimfen Emma C. Paes

Ralph J.P.M. Franken 


\section{Contents}

$\begin{array}{lll}\text { Chapter } 1 & \text { General introduction } & 9\end{array}$

Chapter 2 A cadaver study of the vascular territories of dominant and non-dominant internal mammary artery perforators

Chapter 3 Anatomy of the vascular pedicle of the internal mammary artery perforator (IMAP) flap as applied for head and neck reconstruction

Chapter 4 The internal mammary artery perforator pedicled island flap for reconstruction of the lower head and neck and supraclavicular region: How we do it

Chapter 5 Clinical application and outcome of the internal mammary artery perforator (IMAP) free flap for soft tissue reconstructions of the upper head and neck region in three patients

Chapter 6 Can previous diagnostic examinations prevent preoperative angiographic assessment of the internal mammary perforators for (micro)surgical use?

Chapter 7 Epilogue and discussion

Chapter 8 Summary

Chapter 9 Nederlandse samenvatting

Dankwoord 


\section{Chapter 1}

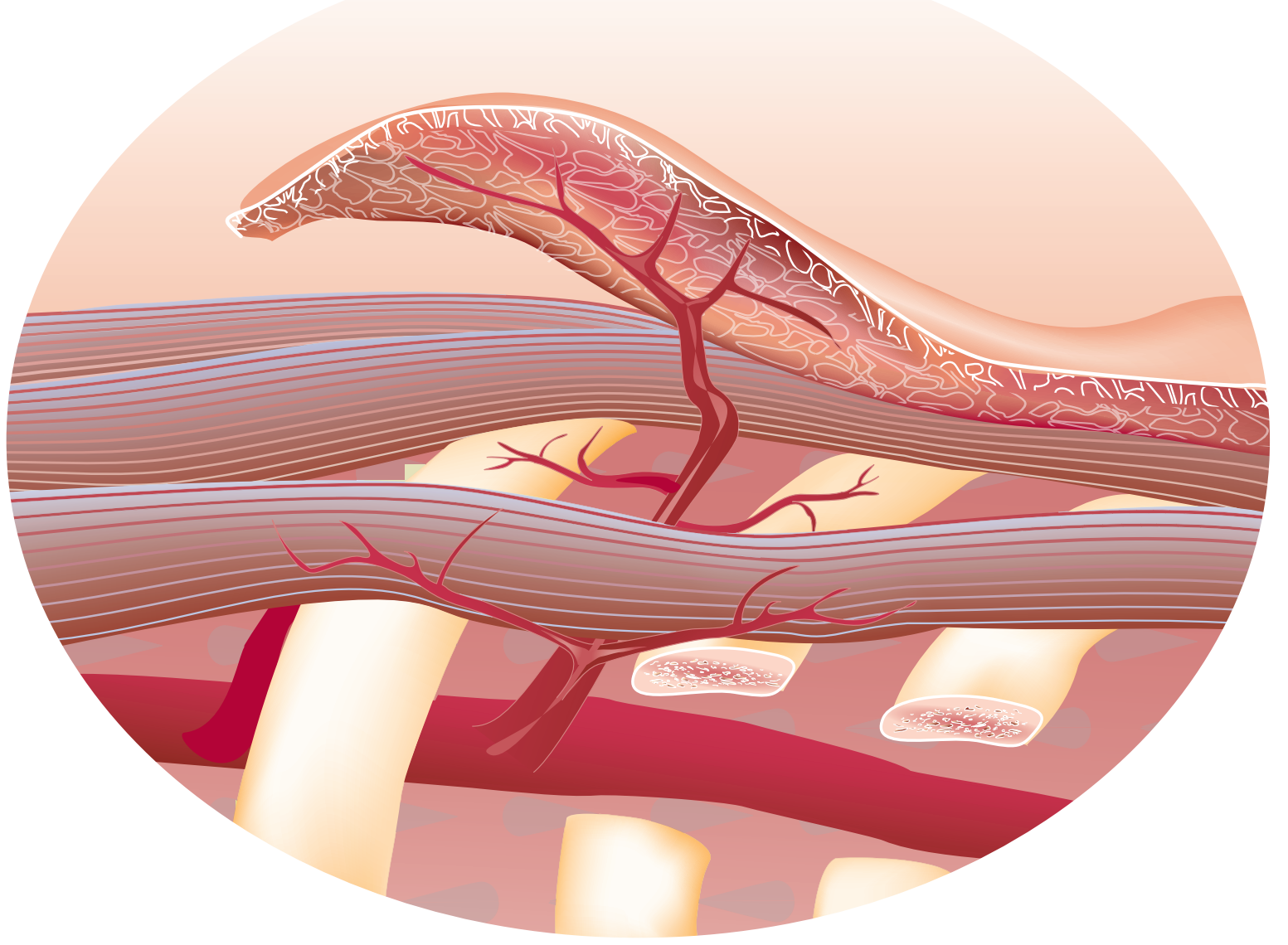


General introduction 
Chapter 1 
Improvements of the functional and aesthetic results of head and neck reconstruction continue to challenge reconstructive surgeons. Tissues that have been resected for oncologic reasons need not only be replaced in kind, ${ }^{1}$ but this replacing tissue should also help to restore function and form of the recipient area. Equally, improvements evolve from innovations and modifications at the donor sites of flaps resulting in better form and function of the donor area.

The evolution of knowledge and understanding of the blood supply to the various tissues used in head and neck reconstructions have expanded the number of flaps and donor sites to choose from. This evolution lead to the development of the internal mammary perforator flap elaborated on in this thesis.

\section{Evolution of the understanding of integumental blood supply}

Die Hautarterien des Menschlichen Körpers

In the early 1880's, the ambitious Swiss medical student Carl Manchot ${ }^{2}$ moved to the Alsace in order to take advantage of the special conditions being offered by the German government to attract students to the University of Strasbourg. At the Kaiser-Wilhelm University Medical School, he completed a monumental review of the cutaneous vasculature within a six months period. By mapping of the vascular anatomy of the skin in a systematic comprehensive fashion he identified distinct skin territories that each receives its blood supply from a source vessel. This work was published in diagrammatic form as Die Hautarterien des Menschlichen Körpers. As this book was published in German in a limited edition that never circulated outside Strasbourg, his work did not come to attention of surgeons for many decades. If it had immediately been brought to the attention of the international medical community, rather than only in 1969, ${ }^{3}$ Manchot's work might have revolutionized skin flap surgery some 100 years earlier.

\section{Artères de la Peau}

In the 1930's Michel Salmon, ${ }^{4}$ a French surgeon and anatomist, performed anatomic dissections and injected vessels with a lead oxide mixture that was used to create detailed radiographic studies of the skin's vasculature. Without any knowledge of Manchot's work Salmon managed to chart many arterial areas, showing the density of their vascular input, the anastomotic links between them, and how adjacent territories were fed by these networks. In his book Artères de la Peau (1936), he described approximately twice the number of vascular territories that was originally proposed by Manchot. ${ }^{2}$ These territories did not correspond exactly with those delineated by Manchot, but they contributed to define the vascular areas supplied by single vessels. 
Unfortunately the clinical implications were again completely ignored until Taylor and Palmer brought Salmon's work up to date with their description of "angiosomes" in 1987.5

\section{Angiosomes of the Body for Tissue Transfer}

In the 1970's and 1980's, a period of innovations in reconstructive flap surgery prompted a renewed appreciation for the relevance of Manchot's and Salmon's original works. On the basis of multiple studies including cadaver dissections and ink and contrast injections, Taylor and co-workers described the angiosome concept: a threedimensional composite unit of tissue supplied by a given source artery. ${ }^{5}$ In 1996, this resulted in the publication of Taylor's book Angiosomes of the Body for Tissue Transfer. ${ }^{6}$ The angiosome principle divides the integumental surface of the body into 40 areas based on named source arteries. These angiosomes are usually linked by reduced caliber "choke" anastomotic vessels, and sometimes by true anastomoses without reduction in caliber. The angiosome concept and the idea that adjacent angiosomes are linked provided the basis for modern integumental flap transfer.

\section{Evolution of integumental flaps}

Arterialized flaps

War has always played an important role in the development of reconstructive surgery and the First World War provided an even greater impetus in which surgeons on both sides took part. It was the Dutchman Johannes Esser, ${ }^{7}$ who applied the clinical concept of a skin flap designed to include a vascular axis while working as a civilian war surgeon for the Austro-Hungarian army during this war. His interest in the blood supply of skin flaps turned out to be an early forerunner of the clinical and anatomical research that would later lead to the definition of the axial-pattern flap, the island flap, and the musculocutaneous flap. Esser developed his "arterialized" island flaps long before the accurate studies of cutaneous vascular anatomy became available. Still, his idea of incorporating a vascular pedicle into a flap remained dormant for decades until Milton(1969) 3,8,9 confirmed Esser's observation that the existence of an adequate vessel in the pedicle is the most important factor in flap survival. Only after this, this principle became a central concept in plastic surgery.

\section{Tubed flaps}

Instead, tubed pedicled flaps as first described by Filatov ${ }^{10}$ became the state-of-art in plastic surgery at the beginning of the twentieth century. The Godfather of Plastic Surgery, Sir Harold D. Gillies, ${ }^{11}$ was primarily responsible for popularizing these tubed 
flaps. Gillies made his name working as a British war surgeon in both the First, and Second World War. When he started working with tubed flaps, Gillies might have been unaware of Filatov because of all the confusion generated by the World War and the Russian Revolution, and because Filatov's work was published only in a Russian ophtalmologic journal. ${ }^{12}$

Gillies developed a flap tradition based on the principles of geometric convenience, largely ignoring the arterial contributions of the skin, presuming a more or less random dermal arteriolar distribution. At the end of World War I, Gillies had become so successful with the random and tubed pedicled flaps that he proceeded with enthusiasm. These techniques helped innumerable patients and the vast experience from the war was applied in civilian practice even though random and tubed flaps were destitute of any underlying anatomic rationale.

Gillies and his dogma on the tubed flap were of such influence ${ }^{13}$ that it was generally accepted to raise random cutaneous flaps without regard to any known blood supply, other than to maintain the presence of the subdermal plexus, until the late 1960's. Using these and other randomized vascularized pedicled flaps, empirical ideas such as the length-to-breadth ratio of flaps and simple trial-and-error approaches to flap elevation all over the body were given much attention even though it was generally known that the blood supply was of vital importance to the survival of skin flaps. Only after Gillies' death (1960), the concept of including a vascular pedicle or muscle carrier in the skin flap to increase the amount of tissue that can be reliably transferred gradually gained attention in the latter half of the twentieth century. ${ }^{14}$

\section{Axial flaps again}

In 1969, Milton 3,9,15,16,17 debunked several of the old maxims with his experiments on the blood supply of skin flaps in pigs. One important conclusion of his work was that the length-to-breadth ratio was unsound in cases where a cutaneous artery was included in the base of the flap. Thus, Esser's observations were experimentally recognized after some 50 years. Consequently, the cutaneous vasculatory anatomy became central to the research and clinical applications of flaps, in the 1970's, and local vascular pedicled flaps became the method of choice for the treatment of tissue defects.

McGregor and Morgan ${ }^{14}$ discovered that some regions of the body had discrete and relatively large subcutaneous vessels that pierced the deep fascia and followed a predictable course. This discovery allowed the creation of comparatively huge cutaneous flaps that were safe as long as they were orientated along the axis of that vascular pathway. In line with Esser's original proposal, ${ }^{18}$ these flaps were called axial flaps. 


\section{Myocutaneous flaps}

Soon thereafter, Ger, ${ }^{19}$ Orticochea ${ }^{20}$ and others began to look at a deeper layer and reintroduced the concept of using muscle as carrier of the overlying skin to create even larger musculocutaneous flaps. Like the axial flap, such a musculocutaneous flap had already been introduced by the Italian surgeon Iginio Tansini ${ }^{21}$ some 60 years before, when he described the use of the latissimus dorsi musculocutaneous flap for closure of a radical mastectomy, in 1906. Based on his experience with this procedure, Tansini already suggested that the cutaneous vascularization was derived from the underlying muscles in certain parts of the body. Although popular between 1910 and 1920, his technique fell out of favour when the defects of mastectomies were closed with the filleted mammary skin.

The rediscovery of the musculocutaneous flaps went fast at the end of the late 1960's. From 1968 to 1978, McCraw and co workers conducted a series of injection studies 22 on the vascularisation of various muscles and the overlying skin and, in a short span of time, a whole range of musculocutaneous flaps was put into practice. ${ }^{23-28}$ In the late 1970 's, Mathes and Nahai ${ }^{29}$ made a classification of the vascular anatomy of muscles. They also published two textbooks on muscle and musculocutaneous flaps, which made this field accessible for surgeons around the world.

\section{Fasciocutaneous flaps}

Meanwhile, another major source of the cutaneous blood supply had completely been overlooked. Ponten ${ }^{30}$ deserves credit for augmenting the cutaneous blood supply by inclusion of the deep fascia: the principle of the fasciocutaneous flaps. Still, he was not quite sure why the inclusion of the deep fascia in his superflaps resulted in better survival of flaps that were safe longer than assumed for random flaps of comparable width. These findings stimulated detailed analysis and classification by Cormack and Lamberty, ${ }^{31}$ with further contributions by Nakajima ${ }^{32}$ et al.

\section{Microsurgical free flaps}

The profound interest and advances in the understanding of the cutaneous circulation in the 1970's and 1980's coincided with the break-through of microsurgery. Although replantations of arm and digit were already performed in the mid 1960's, the first description of a free composite tissue transfer in a human being was published by Antia and Buch, ${ }^{33}$ in 1971. These authors transferred a superficial epigastric artery-based free "dermo-fat graft" to the face anastomosing the blood vessels without the use of an operating microscope. 
The term "free flap" was introduced by Taylor and Daniel 34, 35 in 1973 when they transplanted a free "iliofemoral" flap to an exposed ankle joint by use of an operating microscope. This new entity provided surgeons with entirely new options and the advances in free flap surgery were fast and a wide variety of a flaps became available for microvascular transfer. As such, the development and refinement of microvascular techniques likely is the most significant advancement in reconstructive plastic surgery. As surgical techniques improved and anastomosal successes increased, the focus of microsurgery changed from flap survival toward flap refinement. Flap reconstruction nowadays must provide not only coverage of complex composite tissue defects but at the same time fulfil functional and aesthetic requirements. ${ }^{36}$ Moreover, refinements are being introduced to reduce donor site morbidity. One of the innovations to reduce such morbidity has been the development of the perforator flap.

\section{Evolution of the perforator flap}

Perforator flaps consist of skin and/or subcutaneous tissue supplied by isolated perforating arterial and venous branches that may pass either through, or in between, deeper tissues. These perforating branches derive from a named source vessel and end in the subdermal plexus (Gent consensus, 2003). ${ }^{37}$ On their way to the integument, they may pass through a muscle (musculocutaneous perforator) or a septum (septocutaneous perforator) or they may originate directly from the source vessel. The concept of these flaps is that retrograde dissection of the perforating vessels minimizes the damage to the deeper tissues that they pass through. Anatomical work performed by Onishi ${ }^{38}$ in 1986 suggested that free flaps could be created without muscle sacrifice by pursuing musculocutaneous vessels deep into the muscle, thus minimizing donor site morbidity. That the muscle, once considered the essential carrier of blood supply to more superficial structures including the skin, could be left in its native place to serve its original function, was seen as the most important advantage of this suggestion.

The successful clinical use of retrograde intramuscular dissection was first reported by Koshima and Soeda ${ }^{39}$ in 1989, when they described the transfer of an abdominal skin flap based on a perforating branch of the deep inferior epigastric artery, leaving the rectus abdominis muscle intact. This publication increased the awareness of the clinical applications of intramuscular dissection techniques and helped to debunk the outdated notion that inclusion of the underlying muscle is critical to maintaining the circulation of the overlying skin. The era of perforator flap surgery was initiated and paved the way for pioneers like Allen, ${ }^{40}$ Blondeel, ${ }^{41}$ Boeckx ${ }^{41}$ Hallock, ${ }^{42}$ Kroll, ${ }^{43}$ Koshima, ${ }^{39}$ Wei, ${ }^{44}$ and Neligan ${ }^{45}$ to provide the reconstructive surgeon with further clinical experience and expertise in the use and harvest of perforator flaps. 
In the dawning of this new era, the focus of vascular interest has shifted from the source artery (angiosome concept) to the perforator itself. Recent studies using direct perforator injection combined with static and dynamic computed tomographic angiography have shown that each perforator holds a unique vascular territory that was, consequently, termed the perforasome. ${ }^{46}$ This perforasome has a highly complex and variable vascular territory and, like the angiosomes, perforasomes are linked by direct and indirect vessels. Direct linking vessels are defined as large vessels communicating directly from one perforator to the next that are able to take over adjacent perforasomes through an interperforator flow mechanism. They travel within the suprafascial and adipose tissue layers. Indirect linking vessels maintain the perfusion from one perforator to the next by means of recurrent flow from the subdermal plexus. They can be seen as the choke vessels of Taylors angiosome concept. ${ }^{5}$ Communicating branches between direct and indirect vessels also exist and probable serve as an additional protective mechanism to ensure vascular flow to the skin in the event of damage to either direct or indirect linking vessels.

\section{Evolution of integumetal flaps for head and neck reconstruction}

The anterior chest as donor site

The satisfactory restoration of defects in the head and neck area is hampered by a scarcity of thin flaps with the same colour and texture as the skin of the face and neck. The anterior chest is an interesting donor site for such restorations because of the texture and colour of its skin and the scarcity of hair in women. The use of integumental flaps from the anterior chest for head and neck reconstruction have the advantage that they lack the bulk of traditionally used musculocutaneous flaps such as the pectoralis major flap. Application of loco-regional integumental flaps, furthermore, adheres to Gillies' commandment that losses must be replaced in kind.'

In 1917, Captain J.L. Aymard from the Queen's Hospital for Facial Injuries in Sidcup, United Kingdom, was the first to report nasal reconstruction by use of a medially pedicled, tubed flap extending from the manubrium, through the clavicular region to the left shoulder. ${ }^{47}$ The relevance of the perforating branches of the internal mammary artery and vein, however, was first recognized by Jacques Joseph when he published in 1931 on the successful use of unilateral and bilateral flaps overlying the intercostal space and based on the third and fourth intercostal perforators for closure of neck and mandibular defects. ${ }^{48}$ Conley ${ }^{49}$ similarly reported anterior neck defects reconstructed by use of an anterior chest flap with its medial blood supply derived from these perforating branches, in 1960. Both Joseph and Conley did not actually visualize the perforators but knew them to be included in the skin flap. Likewise, the relevance of 
the lower perforating branches of the internal mammary vessels as the vascular pedicle of a true island flap was proven in $2000,{ }^{50}$ while pedicled breast sharing flaps extending laterally on the same blood supply had already been in use for chest wall and breast reconstruction for over 40 years..$^{51}$

\section{The internal mammary angiosome}

The internal mammary perforators gained popularity particularly after Bakamjian introduced the classic deltopectoral flap, in $1965 .{ }^{52}$ Similar to Aymard's flap but contrary to the flaps reported by Joseph and Conley, the deltopectoral flap was predominately raised from the supraclavicular area and included the adjacent vascular territories of the thoracoacromial axis and deltoid musculocutaneous system to reach over the deltoid muscle. ${ }^{53}$ This extension was necessary because the flap had a relatively wide base that limited its rotation and, consequently, its ability to cover facial defects. Although the use of the free microsurgical modification of this flap was already reported in $1974,{ }^{54}$ it took twenty more years before the pedicled flap was reportedly applied as a true island flap. ${ }^{55}$ This modification allowed for more cranial defects to be reached and for the flap to be less extended, thereby diminishing the tendency for necrosis of its extension beyond the deltoid region. Still closure of the deltopectoral donor defect usually required split skin grafts and left an conspicuous and unsightly supraclavicular scar. ${ }^{56,57}$ Another drawback of the deltopectoral flap was the resulting dog-ear close to the tracheostomy. However despite these drawbacks, it has been the workhorse for major reconstructions in the head and neck throughout the 1960's and 70's.

\section{The internal mammary perforasome}

Since the introduction of free TRAM flaps and free DIEAP flaps for autologous breast reconstruction, plastic surgeons are familiar with the approach to the internal mammary vessels. Still, the use of the perforating branches of these vessels has gained limited popularity. ${ }^{58,59}$ The potential skin territory of the internal mammary artery perforator corresponds to that of the deltopectoral flap overlapping three angiosomes of the anterior chest and shoulder. In 2006, Morain and co-workers ${ }^{60}$ were the first to publish a case of partial pharyngo-oesophageal reconstruction by use of a vertical orientated pedicled pre-sternal skin flap based on three internal mammary perforators that was transposed to the neck by removal of costal cartilage. In the same year, $\mathrm{Yu}^{61}$ reported the clinical application of an internal mammary artery perforator island flap in two reconstructive head and neck cases. He stated that this flap was a refinement of the classic deltopectoral flap and that its use as a free flap would be limited due to the short pedicle length and small flap dimensions. Subsequently, anatomical as well as clinical reports have been published on the internal mammary artery perforator (IMAP) flap. 
In the clinical reports, ${ }^{56,57}$ the vascular pedicle of the IMAP flap consisted of one dominant perforator and an additional second or third perforator. Although there seems to be agreement on the dominancy of internal mammary perforators, there is no consensus on the number of perforators that have to be included in the pedicle of an IMAP flap. In anatomical studies, ${ }^{56,62,63}$ the vascular territory of the internal mammary artery perforators has been documented but the relation between the dominant and non-dominant perforator in skin perfusion has not been clarified. This information is important in order to objectify the merit of the additional inclusion of one or more nondominant perforators in the vascular pedicle of the IMAP flap. The vascular pedicle of an IMAP flap can be lengthened by inclusion of part of the internal mammary vessels ${ }^{64}$ that, additionally, feature a larger diameter than the perforators itself. Such enhancement of the pedicle allows for more cranial recipient sites to be reached using pedicled IMAP flaps, as well as for easier anastomosis of free IMAP flaps. Although the diameter of the perforating branches ${ }^{63,65,66}$ of the internal mammary vessels have been repeatedly studied, the length of the perforator and its enhancement by inclusion of part of the internal mammary vessels had not been systematically assessed anatomically, so far.

\section{Outline of this thesis}

In chapter $\mathbf{2}$ we describe our results of a dye-injection study in nine fresh-frozen cadavers to determine the vascular territory of the dominant internal mammary perforator. The contribution of additional, non-dominant perforators to this skin territory is assessed. In chapter $\mathbf{3}$ we describe the results of our cadaver study in twenty-seven hemithoraxes in which the length of the vascular pedicle of the internal mammary artery perforator flap is studied. The length of the dominant perforator is determined. The enhanced length gained by removal of costal cartilage is additionally presented.

In chapter 4 the clinical application of seven pedicled internal mammary artery perforator flaps for lower head and neck defects is presented. Both the surgical technique and its results are described.

In chapter $\mathbf{5}$ the clinical application and outcome of three microsurgical internal mammary artery perforator free flaps in upper head and neck reconstruction is presented. The surgical technique and results are described. The alleged need for a pre-operative evaluation of the patency and dominancy among the internal mammary perforating vessels is discussed and possible alternative sources of this information are presented in chapter 6 .

Finally, chapter $\mathbf{7}$ features an epilogue and the conclusions of our studies. An opinion on head and neck reconstruction in the future is presented. 


\section{References}

1. FitzGibbon GM. The commandments of Gillies. Br J Plast Surg. 21, 226-239, 1968.

2. Manchot C. Die Hautarterien des menschlichen Körpers. Leipzig, FCW Vogel, 1889.

3. Milton SH. The tubed pedicle flap. Br J of Plast Surg. 22, 53-59, 1969.

4. Salmon M. Artères de la Peau. Paris, Masson et Cie, 1936.

5. Taylor Gl, Palmer JH. The vascular territories (angiosomes) of the body: experimental study and clinical applications. Br J Plast Surg. 40,113-141, 1987.

6. Taylor G. Angiosomes of the body for tissue transfer. Londen, Churchill Livingstone, 1996.

7. Esser JFS. Deckung von Gaumendefekten mittels gestielter Naso-Labial-Hautlappen. D Ztschr Chir. $147,128-135,1918$.

8. Milton SH. Pedicled skin flaps-the fallacy of the length: width ratio. Br J Plast Surg. 56, 381-381, 1969.

9. Milton SH. The effects of "delay" on the survival of experimental pedicled skin flaps. Br J of Plast Surg. 22, 244-52, 1969.

10. Filatov VP. Plastic procedure using a round pedicle. Vestnik Oftalmol 34 149-158, 1917.

11. Gillies HD. Practical uses ot the tubed pedicle flap. Am J of Surg. 43, 201, 1939.

12. Santoni-Rugiu P, Sykes PJ. A history of plastic surgery. Berlin, Springer-Verlag, 2007.

13. Haeseker B. JFS Esser and his influence on the development of plastic and reconstructive surgery. Thesis, Rotterdam, 1983.

14. McGregor IA, Morgan G. Axial and random pattern flaps. Br J of Plast Surg. 26, 202-213, 1973.

15. Milton SH. The effects of "delay" on the survival of experimental pedicled skin flaps. Br J Plast Surg. 22, 244-252, 1969.

16. Milton $\mathrm{SH}$. Experimental studies on island flaps. I. The surviving length. Plast Reconstr Surg. 48, 574-578, 1971.

17. Milton SH. Experimental studies on island flaps. II. Ischemia and delay. Plast Reconstr Surg. 49, 444447, 1972.

18. Esser JFS. Artery Flaps. Antwerpen, De Vos-van Kleef, 1929.

19. Ger R. Surgical management of ulcerative lesions in the leg. Curr Probl Surg. 1-52, 1972.

20. Orticochea M. Immediate (undelayed) musculocutaneous island cross leg flaps. Br J Plast Surg. 31, 205-209, 1978.

21. Tanzini I. Sopra il mio nuovo processo di amputasione della mammella. Gaz Med Ital. 51, 140, 1906.

22. McCraw JB, Dibbell DG. Experimental definition of independent myocutaneous vascular territories. Plast Reconstr Surg. 60, 212-220, 1977.

23. McCraw JB, Dibbell DG Carraway JH. Clinical definition of independent myocutaneous vascular territories. Plast Reconstr Surg. 60, 341-352, 1977.

24. McCraw JB, Magee WP Jr, Kalwaic H. Uses of the trapezius and sternomastoid myocutaneous flaps in head and neck reconstruction. Plast Reconstr Surg. 63, 49-57, 1979.

25. McCraw JB, Vasconez LO. Musculocutaneous flaps: principles. Clin Plast Surg. 7, 9-13, 1980.

26. McCraw JB, Massey FB, Shanklin KD, Horton CE. Vaginal reconstruction with gracilis myocutaneous flaps. Plast Reconstr Surg. 58, 176-183, 1976.

27. McCraw JB, Fishman JH, Sharzer LA. The versatile gastrocnemius myocutaneous flap. Plast Reconstr Surg. 62, 15-23, 1978.

28. Becker DW Jr, Massey FM, McCraw JB. Musculocutaneous flaps in reconstructive pelvic surgery. Obstet Gynecol. 54, 178-183, 1979.

29. Mathes SJ, Nahai F. Classification of the vascular anatomy of muscles: experimental and clinical correlation. Plast Reconstr Surg. 67, 177-187, 1981.

30. Pontén B. The fasciocutaneous flap: its use in soft tissue defects of the lower leg. Br J Plast Surg. 34 215-220, 1981.

31. Cormack GC, Lamberty, BGH. A classification of fasciocutaneous flaps according to their patterns of vascularisation. Br J Plast Surg. 37, 80-87, 1984. 
32. Nakajima H, Fujino T, Adachi S. A new concept of vascular supply to the skin and classification of skin flaps according to their vascularization. Ann Plast Surg. 16, 1-19, 1986.

33. Antia NH, Buch VI. Transfer of an abdominal dermo-fat graft by direct anastomosis of blood vessels. Br J Plast Surg. 24, 15-19, 1971.

34. Taylor Gl, Daniel RK. The free flap: composite tissue transfer by vascular anastomosis. Aust N Z J Surg. 43, 1-3, 1973

35. Daniel RK, Taylor GI. Distant transfer of an island flap by microvascular anastomoses. A clinical technique. Plast Reconstr Surg. 52, 111-117, 1973.

36. Hamdi M, Van Landuyt K, Blondeel P, Monstrey S. Aesthetic and functional considerations in the reconstruction of large skin defects with free flaps. Clin Plast Surg. 31, 39-48, 2004.

37. Blondeel PN, Van Landuyt KH, Monstrey SJ, Hamdi M, Matton GE, Allen RJ, Dupin C, Feller AM, Koshima I, Kostakoglu N, Wei FC. The "Gent" consensus on perforator flap terminology: preliminary definitions. Plast Reconstr Surg. 112, 1378-1383; quiz 1383, 1516; discussion 1384-1387, 2003.

38. Onishi KY. Cutaneous and fascial vasculature around the rectus abdominis muscle: anatomic basis of abdominal fasciocutaneous flaps. J Reconstr Microsurg. 2, 247-253, 1986.

39. Koshima I, Soeda S. Inferior epigastric artery skin flaps without rectus abdominis muscle. Br J Plast Surg. 42, 645-648, 1989.

40. Allen RJ, Treece P. Deep inferior epigastric perforator flap for breast reconstruction. Ann Plast Surg. 32, 32-38, 1994.

41. Blondeel PN, Boeckx WD. Refinements in free flap breast reconstruction: the free bilateral deep inferior epigastric perforator flap anastomosed to the internal mammary artery. Br J Plast Surg. 47, 495-501, 1994.

42. Hallock GG. The medial circumflex femoral (gracilis) local perforator flap, a local medial groin perforator flap. Ann Plast Surg. 51, 460-464, 2003.

43. Kroll SS, Rosenfield L. Perforator-based flaps for low posterior midline defects. Plast Reconstr Surg. 81, 561-566, 1988.

44. Wei, FC Jain V, Suominen S, Chen HC. Confusion among perforator flaps: what is a true perforator flap? Plast Reconstr Surg. 107, 874-876, 2001.

45. Neligan PC, Gullane PJ, Vesely M, Murray D. The internal mammary artery perforator flap: new variation on an old theme. Plast Reconstr Surg. 119, 891-893, 2007.

46. Saint-Cyr M, Wong C, Schaverien M, Mojallal A, Rohrich RJ. The perforasome theory: Vascular anatomy and clinical implications. Plast Reconstr Surg. 124, 1529-1544, 2009.

47. Aymard JL. Nasal reconstruction. With a note on nature's plastic surgery. Lancet. 2, 888, 1917.

48 Joseph J. Nasenplastik und sonstige Gesichtsplastik, nebst einem Anhang über Mammaplastik. Verlag C. Kabitzsch, Leipzig, 1931.

49. Conley JJ. The use of regional flaps in head and neck surgery. Ann Otol Rhinol Laryngol. 69, 12231234, 1960.

50. Kalender V, Aydm H, Karabulut AB, Ozcan M, Amiraslanov A. Breast reconstruction with the internal mammary artery pedicled fasciocutaneous island flap: description of a new flap. Plast Reconstr Surg. 106, 1494 - 1498; discussion 1499-1500, 2000.

51. Holdsworth WG . A method of reconstructing the breast. Br J Plast Surg. 9, 161-162, 1956.

52. Bakamjian VY, Long M, Rigg B. Experience with the medially based deltopectoral flap in reconstructuve surgery of the head and neck. Br J Plast Surg. 24, 174-183, 1971.

53. Daniel RK, Cunningham DM, Taylor Gl. The deltopectoral flap: an anatomical and hemodynamic approach. Plast Reconstr Surg. 55, 275-282, 1975.

54. Harii K, Ohmori K, Ohmori S. Free deltopectoral skin flaps. Br J Plast Surg. 27, 231-239, 1974.

55. Portnoy WM, Arena S. Deltopectoral island flap. Otolaryngol Head Neck Surg. 111, 63-69, 1994.

56. Vesely MJJ, Murray DJ, Novak CB, Gullane PJ, Neligan PC. The internal mammary artery perforator flap. Ann Plast Surg. 58, 156-161, 2007.

57. Neligan PC, Gullane PJ, Vesely MJJ, Murray D. The internal mammary artery perforator flap: new variation on an old theme. Plast Reconstruct Surg 119, 891-893, 2007. 
58. Hamdi M, Blondeel PN, Van Landuyt KJ, Monstrey SJM. Algorithm in choosing recipient vessels for perforator free flap in breast reconstruction: the role of the internal mammary perforators. $\mathrm{Br} J$ Plast Surg. 57, 258-265, 2004.

59. Follmar KE, Prucz RB, Manahan MA, Magarakis M, Rad AN, Rosson GD. Internal mammary intercostal perforators instead of the true internal mammary vessels as the recipient vessels for breast reconstruction. Plast Reconstr Surg.127, 34-40, 2011.

60. Morain WD, Hallock GG, Neligan PC. Internal mammary artery perforator flap, Pp 429-439. In Perforator flaps. Anatomy, Techniques \& Clinical Applications. Blondeel PN, Morris SF, Hallock GG, Neligan PN(ed). Quality Medical Publishing, St Louis MI, 2006.

61. Yu P, Roblin P, Chevray P. Internal mammary artery perforator (IMAP) flap for tracheostoma reconstruction. Head Neck. 28, 723-729, 2006.

62. Schmidt M, Aszmann OC, Beck H, Frey M. The anatomic basis of the internal mammary artery perforator flap: a cadaver study. J Plast Reconstr Aesth Surg. 63, 191-196, 2010.

63. Saint-Cyr M, Schaverien M, Rohrich RJ. Pre-expanded second intercostal space internal mammary artery pedicle perforator flap: case report and anatomical study. Plast Reconstr Surg. 123, 16591664, 2009.

64. Sasaki K, Nozaki M, Honda T, Morioka K, Kikuchi Y, Huang T. Deltopectoral skin flap as a free skin flap revisited: further refinement in flap design, fabrication, and clinical usage. Plast Reconstr Surg. 107, 1134-1141, 2001.

65. Hamdi M, Blondeel PN, Van Landuyt KJ, Monstrey SJM. Algorithm in choosing recipient vessels for perforator free flap in breast reconstruction: the role of the internal mammary perforators. $\mathrm{Br} J$ Plast Surg. 57, 258-265, 2004.

66. Rosson GD, Holton LH, Silverman RP, Singh NK, Nahabedian MY. Internal mammary perforators: a cadaver study. J Reconstr Microsurg. 21, 239-242, 2005. 


\section{Chapter 2}




\title{
A cadaver study of the vascular territories of dominant and non-dominant internal mammary artery perforators
}

\author{
Emma C. Paes \\ Pascal P.A. Schellekens \\ J. Joris Hage \\ Martijn B.A. van der Wal \\ Ronald L.A.W. Bleys \\ Moshe Kon
}

Ann Plast Surg. 2011 Jul;67(1):68-72.

Presented at the Spring Meeting of the Dutch Society of Plastic Surgery,

April 3, 2009 


\begin{abstract}
The perfusion territory of the pedicled internal mammary artery perforator (IMAP) flap has been described, though the number of perforators to be included in the flap's pedicle is controversial. We studied the vascular territory of the dominant perforator and the contribution of additional non-dominant perforators to it. Therefore, the dominant perforators in nine fresh cadavers and the non-dominant perforators in four of these, were injected with water-based ink. The dominant perforator vascularized a territory extending from the superior border of the clavicle to the xyphoid, and from mid-sternal to the anterior axial fold, with a mean craniocaudal length of $19.4 \mathrm{~cm}$ (range, 17.0 - 24.0) and a mean mediolateral width of $18.6 \mathrm{~cm}$ (range, 16.0 - 22.5). Additional injection of non-dominant perforators did not lead to any substantial enlargement of this territory. One single dominant perforator vascularizes a large part of the hemi-thorax, allowing for various flap designs. Non-dominant perforators do not have to be included in the vascular pedicle of the IMAP-flap, leading to less donor site morbidity.
\end{abstract}




\section{Introduction}

The internal mammary artery usually arises from the lower aspect of the first part of the subclavian artery. It passes downward, forward, and medially, behind the sternocleidomastoid muscle, the clavicle, and the subclavian and internal jugular veins. Joined by the internal mammary vein, it passes further downward behind the upper six costal cartilages and the intervening internal intercostal muscles, just lateral to the sternum. It ends at the sixth intercostal space by dividing into its terminal branches, the superior epigastric and musculophrenic arteries. A perforating branch of both the internal mammary artery and vein is located in each of the upper six intercostal spaces. A bilateral skin flap based on the third and fourth of these perforators was first described by Jacques Joseph, in 1931. ${ }^{2}$ In 1965, Bakamjian ${ }^{3}$ introduced the deltopectoral flap based on the first four perforators and extending into the adjacent vascular territory of the thoracoacromial axis. Such extension often led to partial flap loss, ${ }^{4-9}$ a large donorsite defect requiring a skin graft, ${ }^{9,10}$ and a wide medial based skin pedicle resulting in an unsightly dog ear and a limited arc of rotation. ${ }^{5,9}$ Consequently, the deltopectoral flap was largely replaced by the pectoralis major flap after its popularization by Ariyan, from 1979 onward. ${ }^{11}$ Rather than using its thoracoacromial axis, Morain and co-workers introduced a more versatile use of the deltopectoral flap based solely on one or more of the perforators of the internal mammary artery. ${ }^{12}$ Subsequently, several reports have been published on the clinical application of this internal mammary artery perforator (IMAP) flap for reconstructions of the breast ${ }^{13-16}$ and the anterior chest and head and neck regions. ${ }^{17-19}$ Recently, Saint-Cyr et al. introduced pre-expansion of the flap as a means to minimize its donor site morbidity. ${ }^{20}$

Depending on the location of the defect, one or more of the cranial or caudal internal mammary perforators are used for the vascular pedicle of the IMAP flap. Several studies showed that there is one dominant perforator ${ }^{21-24}$ with a diameter that is twice as large as that of the other perforators. 'The vascular pedicle of the IMAP flap may exclusively consist of the dominant perforator but, ${ }^{18-20}$ in most cases, one ${ }^{13,14,16,17}$ or more ${ }^{12}$ nondominant perforators are additionally included. Thus, there seems to be no consensus whether to include one or more perforators in the pedicle. To date, anatomic studies on the vascular territory of the dominant and non-dominant IMAP's are sparse. Vesely and co-workers verified the territory of the IMAP flap by injecting all five upper perforators and, consequently, they did not objectify the vascular territory of each individual perforator. ${ }^{18}$ Recently, Schmidt et al. ${ }^{24}$ investigated the territory of individual perforators but their study did not distinguish between the role of the dominant and non-dominant perforators in the perfusion of the IMAP flap. Saint-Cyr and co-workers limited their study to the vascular anatomy of the second perforator. ${ }^{20}$ 
The aim of our study was to gain detailed information on the vascular territory of the dominant internal mammary perforator and to objectify the merit of additionally including one or more non-dominant perforators in the vascular pedicle of the IMAP flap.

\section{Material and Methods}

The clavicle, jugulum, sternum boarder, xiphoïd and anterior axial fold were marked on nine cadavers (four male, five female, mean age 76 year) with no history of mammary, thoracic, or cardiac surgery, within the first 24 hours post-mortem. After measurement of the distances between these anatomical landmarks, fasciocutaneous flaps that extended well beyond these landmarks were bilaterally raised in the subfascial plane. On each side, the dissection was performed laterally to medially and each flap was isolated on all perforators thus encountered (Table 1). Using 2.8x magnification, the dominant perforator was easily determined and the internal mammary artery (IMA) was approached by dissection of the pectoralis major and intercostal muscles and the adjacent costal cartilage.

In five cadavers, an 18-gauge catheter was inserted in the IMA just cranially to the dominant perforator and the IMA was tied off both cranially and caudally to this perforator to prevent leakage and perfusion through the other perforators (Fig. 1). Approximately $30 \mathrm{~mL}$ of water-based ink $(0.1 \%$ Light Green, SF Sigma Alldrich Chemie BV, Zwijndrecht, the Netherlands or $0.1 \%$ Methylene Blue, E. Merck, Darmstadt, Germany) was injected under standard experimental conditions in accordance to the technique described by Vesely et al. ${ }^{18}$, until leakage of ink occurred from the cut vessels at the flap's edges and the skin staining was observed. Immediately after injection, staining of the skin was photographed and measured in craniocaudal and mediolateral direction. ${ }^{18,24}$

In the four other cadavers, non-dominant perforators were injected before injecting the dominant perforators bilaterally. This was done with a different color of ink to verify the contribution of these additional perforators to the vascularization of the IMAP flap. 


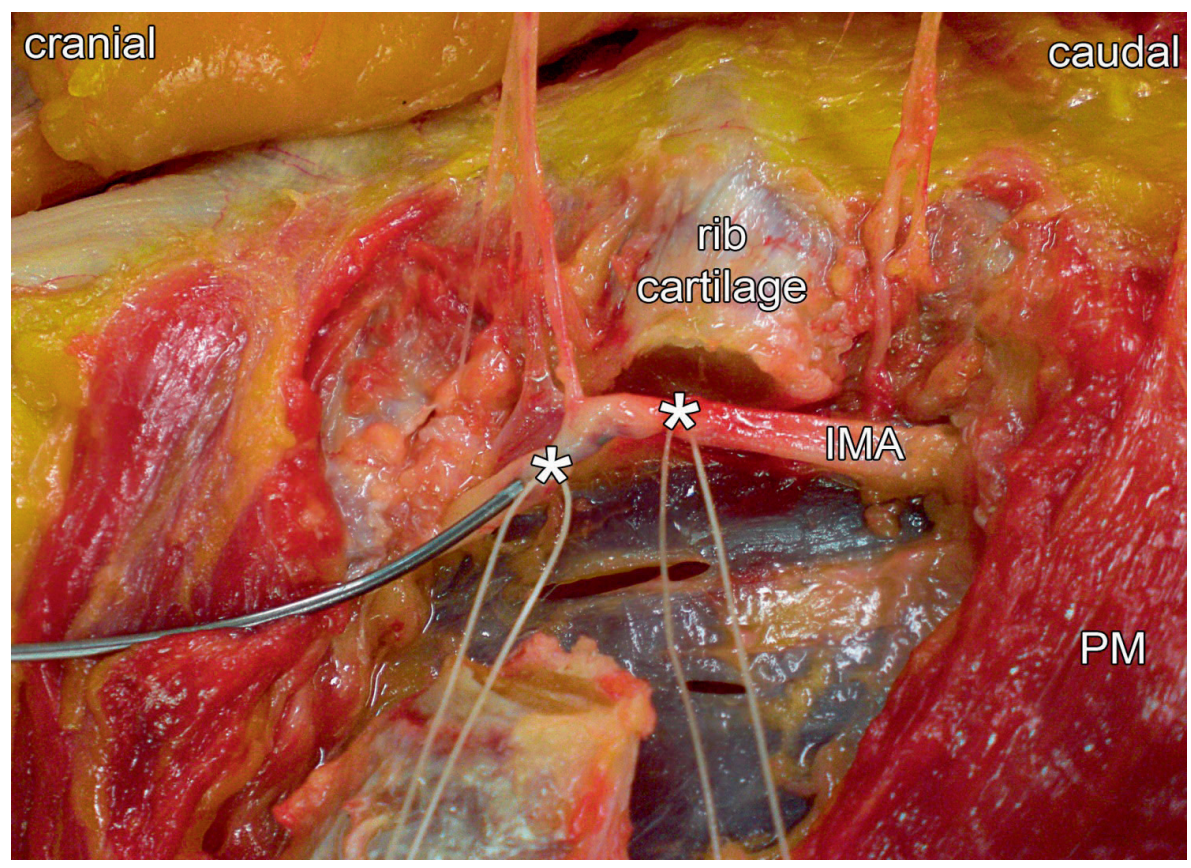

Figure 1: The internal mammary artery (IMA) was approached by dissection of the pectoralis major (PM) and intercostal muscles and the adjacent rib cartilage. The IMA was canulated and tied off both cranially and caudally to the dominant perforator to prevent leakage and diffusion of the ink through the other perforators.

\section{Results}

In all of our cases, the dominant perforator was easily recognized macroscopically by its diameter that was clearly larger than that of the non-dominant perforators. The second perforator was found to be dominant in 15 of our 18 cases $(0.83)$, whereas the first perforator was dominant in one case, and the third bilaterally in one cadaver (Table 1). 
Table 1: Intercostal spaces in which all perforators, respectively the dominant perforators were found

\begin{tabular}{lccc}
\hline $\begin{array}{l}\text { Side of } \\
\text { Cadaver }\end{array}$ & $\begin{array}{c}\text { Encountered } \\
\text { perforators }\end{array}$ & $\begin{array}{c}\text { Dominant } \\
\text { perforator }\end{array}$ & $\begin{array}{c}\text { Non-dominant perforator } \\
\text { injected additionally }\end{array}$ \\
\hline 1 right & 2,3 & 2 & - \\
1 left & $2,3,4$ & 2 & - \\
2 right & $1,2,3$ & 2 & - \\
2 left & 2,3 & 2 & - \\
3 right & $1,2,3,4,5$ & 1 & - \\
3 left & $2,3,4$ & 2 & - \\
4 right & 2,3 & 2 & - \\
4 left & $1,2,3$ & 2 & - \\
5 right & $2,3,4$ & 2 & - \\
5 left & 2,4 & 2 & - \\
6 right & $1,2,3$ & 2 & 3 \\
6 left & $2,3,4$ & 2 & 3 \\
7 right & $2,3,4$ & 2 & 3 \\
7 left & $2,3,4$ & 2 & 1 \\
8 right & $1,2,3$ & 3 & 3 \\
8 left & $1,2,3$ & 3 & 4 \\
9 right & $2,3,4$ & 2 & - \\
9 left & $2,3,4$ & 2 & - \\
\hline
\end{tabular}

The vascularized area of the dominant perforator was consistent in all studied cadavers. Skin staining extended from the cranial border of the clavicle to the xyphoid and from mid-sternal to the anterior axial fold. No major differences were observed between the left and right hemi-thorax of each cadaver (Fig. 2). Even in cases where the dominant perforator was located in a different intercostal space, the skin staining showed similar dimensions. The mean craniocaudal length of staining through the dominant IMAP measured $19.4 \mathrm{~cm}$ and the mean mediolateral width, $18.6 \mathrm{~cm}$ (Table 2). Relative to the distances between the landmarks, the dominant IMAP vascularized a territory that covered 97 percent of the length, and 104 percent of the width of the hemi-thorax (Table 2 ). In 7 of the 18 cases (0.39), the ink perfused contralaterally across the midline of the sternum, mainly in the cranial half of the vascular territory (Fig. 2). Injection with a different color of ink through non-dominant perforators did not result in any substantial enlargement of skin staining (Fig. 3). 


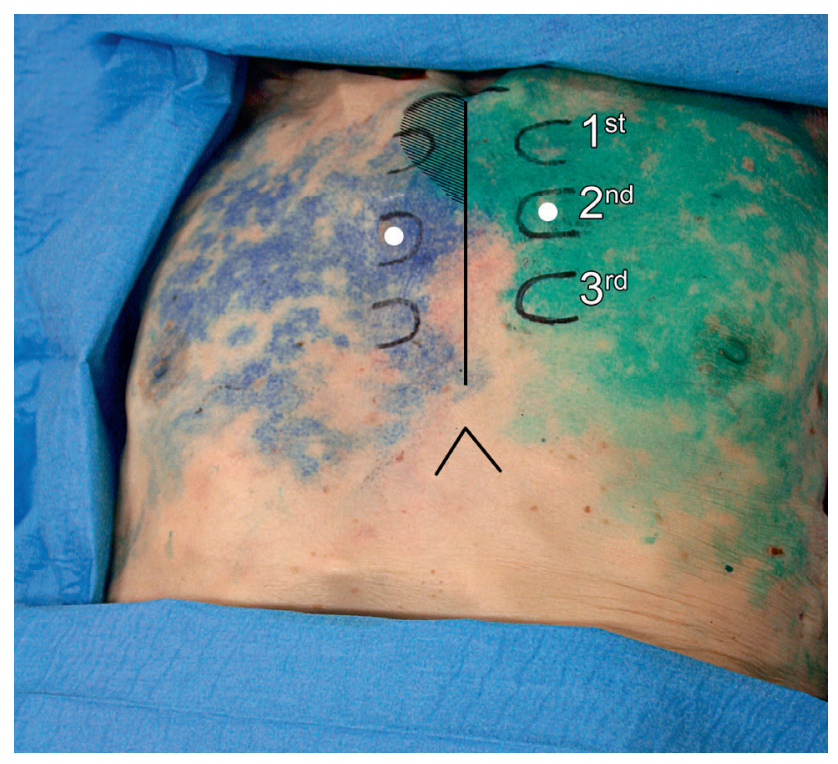

Figure 2: In this cadaver the second perforator was dominant bilaterally (white dots). Both sides were injected with ink. The vascular territory consistently extended from the cranial border of the clavicle to xiphoid, and from mid-sternal to the anterior axillary fold. In 7 of the 18 cadavers (0.39), the skin staining extended contralaterally beyond the mid-sternum (straight line).

Table 2: Dimensions of skin staining in absolute measurements and relative to anatomical distances

\begin{tabular}{lcccccc}
\hline $\begin{array}{l}\text { Side of } \\
\text { Cadaver }\end{array}$ & $\begin{array}{c}\text { Cranio-caudal } \\
\text { staining }(\mathrm{cm})\end{array}$ & $\begin{array}{c}\text { Jugulo-xyphoid } \\
\text { distance }(\mathrm{cm})\end{array}$ & $\%$ & $\begin{array}{c}\text { Medio-lateral } \\
\text { staining }(\mathrm{cm})\end{array}$ & $\begin{array}{c}\text { Midsterno-axillar } \\
\text { distance }(\mathrm{cm})\end{array}$ & $\%$ \\
\hline 1 right & 19.0 & 20.5 & 0.93 & 18.0 & 19.5 & 0.92 \\
1 left & 19.0 & 20.5 & 0.93 & 17.5 & 19.5 & 0.90 \\
2 right & 19.0 & 17.5 & 1.09 & 18.0 & 22.5 & 0.80 \\
2 left & 19.0 & 17.5 & 1.09 & 17.0 & 22.5 & 0.76 \\
3 right & 22.0 & 20.0 & 1.10 & 19.0 & 17.0 & 1.12 \\
3 left & 23.0 & 20.0 & 1.15 & 20.0 & 17.0 & 1.18 \\
4 right & 21.5 & 22.5 & 0.96 & 19.0 & 21.0 & 0.90 \\
4 left & 22.5 & 22.5 & 1.00 & 19.0 & 1.5 & 0.88 \\
5 right & 17.0 & 21.5 & 0.79 & 14.0 & 17.5 & 0.78 \\
5 left & 17.5 & 21.5 & 0.81 & 16.0 & 16.0 & 0.91 \\
6 right & 18.0 & 22.0 & 0.68 & 15.0 & 16.0 & 1.19 \\
6 left & 19.0 & 22.0 & 0.86 & 19.0 & 16.0 & 1.38 \\
7 right & 15.0 & 18.5 & 0.81 & 22.0 & 16.0 & 1.43 \\
7 left & 15.0 & 18.5 & 0.81 & 23.0 & 16.5 & 1.33 \\
8 right & 19.0 & 19.5 & 0.97 & 22.0 & 16.5 & 1.21 \\
8 left & 18.0 & 19.5 & 0.92 & 20.0 & 18.0 & 1.00 \\
9 right & 24.0 & 18.0 & 1.33 & 18.0 & 1.0 & 1.00 \\
9 left & 21.0 & 18.0 & 1.17 & 18.0 & & \\
\hline
\end{tabular}




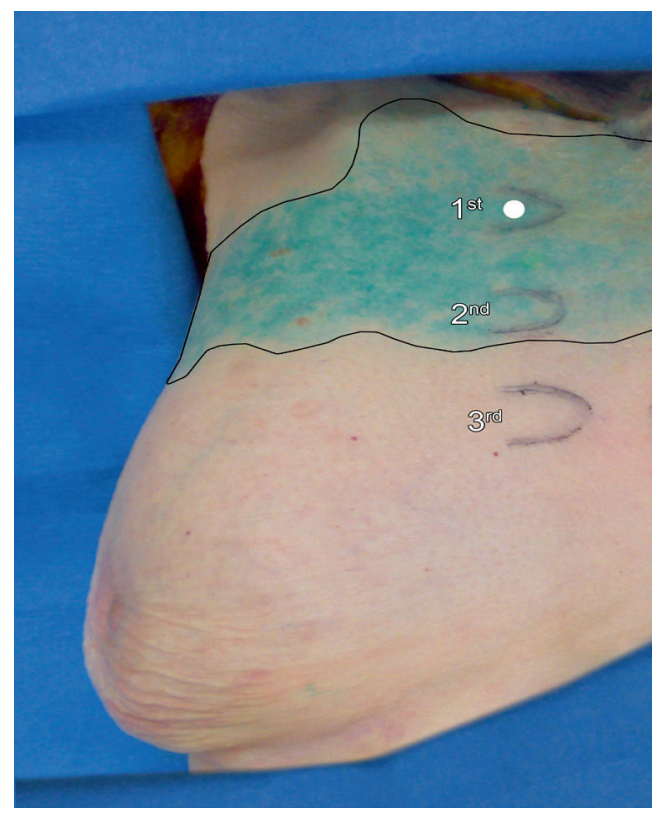

Figure 3A: First the non-dominant perforator of the right side (red dot) was injected with green ink.

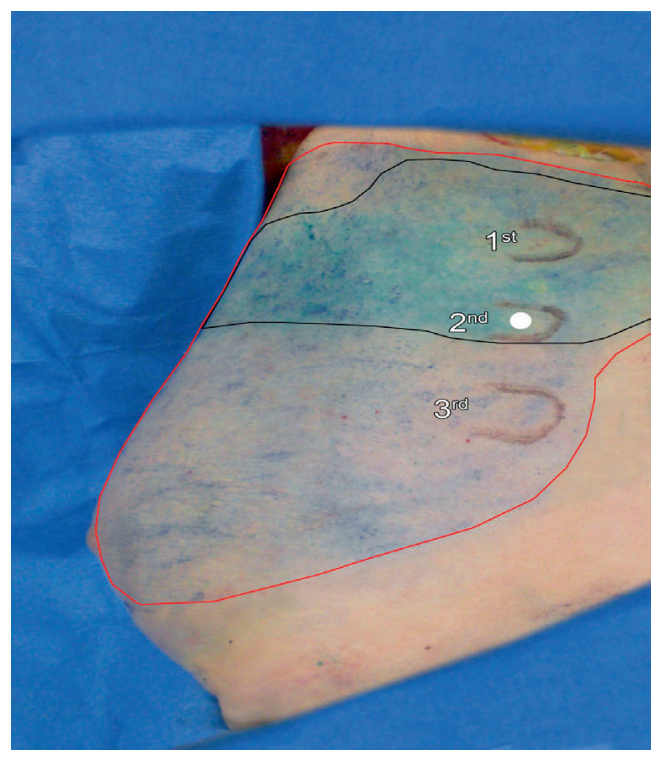

Figure 3B: Subsequently, the dominant second perforator of the same side (white dot) was injected with blue ink, showing an increase in the perfusion territory that also covers the area of the non-dominant perforator. 


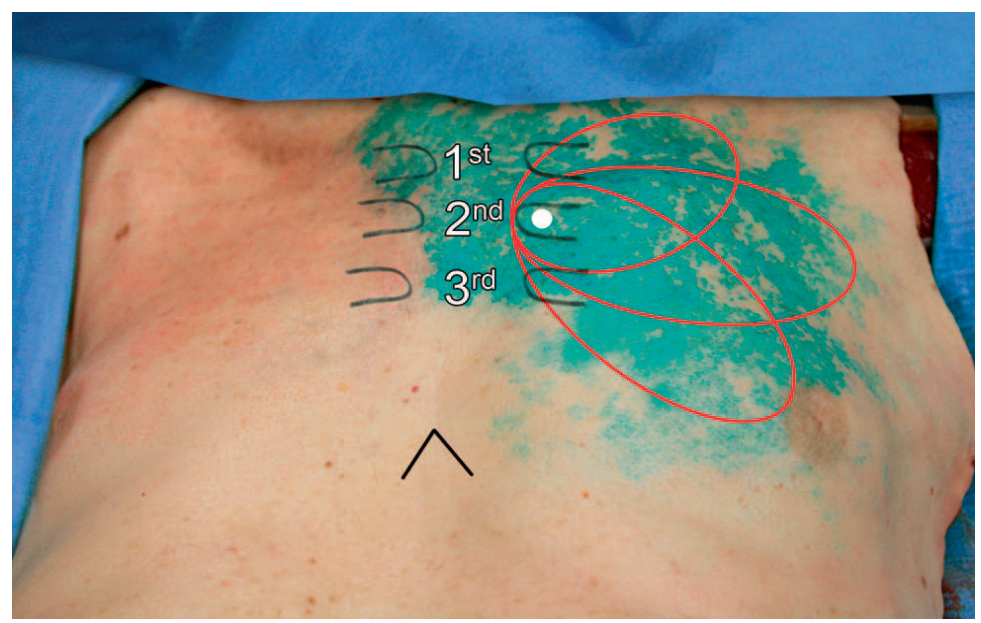

Figure 4: There are many options to design an equally vascularized flap pedicled solely on the dominant perforator (white dot).

\section{Discussion}

The IMAP flap pedicled on the dominant perforator is a suitable and reliable alternative for coverage of soft tissue defects in the mammary, anterior thoracic, and head and neck regions. It may provide a thin and pliable skin flap with excellent color match to cover large and relatively cranially located defects. To date, we have clinically applied the IMAP pedicled island flap in five oncological head and neck patients. ${ }^{25}$ Enhancement of its pedicle up to $104 \mathrm{~mm}$ by resection of the costal cartilage and inclusion of the internal mammary vessels cranially to the perforator will increase the cranial arc of rotation of the flap. ${ }^{26}$

The concept of one dominant internal mammary perforator was first described by Palmer and Taylor, in 1986. ${ }^{1}$ They investigated 20 cadavers and found that the largest perforator was at least twice the diameter of the second largest vessel in $85 \%$ of their cases. Like us, Palmer and Taylor always found the dominant perforator to be located in the first four intercostal spaces and, most commonly, in the second. ${ }^{1}$ Studies considering these perforators as recipient vessels in microsurgical breast reconstructions have further verified the locations of the dominant perforator. 22, 23, 27 Clinically, we easily distinguish the dominant perforator from the non-dominant perforators, even when using a medial approach of the pedicle. Still, the location of the dominant IMAP is variable $^{1,22-24}$ and preoperative assessment by Color Duplex or angiographic imaging is advisable. ${ }^{12,18,19,24}$ 
We found the vascular territory of the dominant perforator to be independent of its origin, in all studied cadavers. This dominant perforator vascularized an area reaching consistently from the clavicle to the xiphoid and from mid-sternal to the anterior axillary fold, allowing multiple clinical designs for the IMAP fasciocutaneous flap (Fig. 4). In 7 of the 18 flaps (0.39), the staining even reached contralaterally across the midline. This explains why the territory of the deltopectoral flap may be expanded by 3 to $4 \mathrm{~cm}$ beyond the ipsilateral parasternal line. ${ }^{28}$ According to Boyd et al., ${ }^{29}$ a flap can be raised beyond the borders found in an ink perfusion study, possibly leading to an even larger applicability. Alternatively, bilateral flaps can be raised using the dominant perforator on each side of the sternum to increase the size that may be covered while still allowing for primary closure of the donor sites. ${ }^{12,17-19}$ Application of larger flaps may imply the use of $\mathrm{V}-\mathrm{Y}$ advancement techniques in combination with a skin graft to prevent distortion of the nipple areola complex, particularly in female patients. ${ }^{28}$ Moreover, pre-expansion of the flap may minimize the donor site morbidity. ${ }^{20}$

In any perforator flap, reconstructive surgeons try to include as many perforators as possible. Even if a study confirms one dominant perforator and one or two nondominant perforators, this would not imply that additional perforators should not be utilized during in vivo dissection. Still, additional injection of non-dominant perforators did not substantially enlarge the area of skin staining. This suggests that additional inclusion of a non-dominant perforator in the pedicle has no influence on the size of the flap. Such inclusion, furthermore, could carry the disadvantage of removal of extra rib cartilage to obtain the same rotational capacity leading to a more complex and longer operation and increased risk of complications. To include extra non-dominant perforators in the pedicle of a flap based on the dominant IMAP and to obtain sufficient rotation of the flap's pedicle, Morain et al. ${ }^{12}$ removed two costal cartilages. This increases the risk of iatrogenic pneumothorax ${ }^{30}$ contour deformity of the thorax, ${ }^{31,32}$ and intercostal neuralgia. ${ }^{33,34}$

That the IMAP flap is variously pedicled on either one dominant perforator or multiple perforators might be a consequence of insufficient knowledge of the perforators' vascular territories. To date, not much evidence was gathered to safely warrant the maximum measurements of the IMAP flap. Consequently, only relatively small flaps ranging from $10 \times 11 \mathrm{~cm}^{17}$ and $7 \times 17 \mathrm{~cm}^{18}$ to $5 \times 12 \mathrm{~cm}^{19}$ and $5 \times 13 \mathrm{~cm}^{19}$ have reportedly been used clinically for reconstructions in the head and neck region. Vesely et al. ${ }^{18}$ were the first to perform a perfusion study to precede their clinical case. In five cadavers they raised a skin flap either as anterior chest flap based on the upper five perforators, or as an IMAP flap based exclusively on one perforator and injected them with water based ink. However, in four cadavers more than one perforator was injected 
and therefore their study did not provide useful information about the perfusion territory of the individual perforators. ${ }^{18}$ Only recently, Schmidt et al. ${ }^{24}$ published an anatomical study of the IMAP in ten cadavers. Theirs is the first study where the perforators were injected separately. The first, third, and fourth perforator of the left side and the second and fifth of the right side were injected with Methylene Blue solution, in six cadavers. In the other four cadavers the corresponding dissection sites were switched. Per perforator they described the average size of the colored skin. The largest area was found for the second perforator $(9 \times 16 \mathrm{~cm})$, the smallest for the fifth $(4 \times 8 \mathrm{~cm})$ and the area of the first, third and fourth perforator were almost similar $(8 \mathrm{x}$ $13 \mathrm{~cm}, 7 \times 11.5 \mathrm{~cm}$, and $6 \times 11.5 \mathrm{~cm}$ respectively). Although these authors presented detailed information about the individual perforators, they used only one color for the injections on a cadaver. This makes it difficult to assess the exact borders of the vascular territory per perforator, illustrated by a somewhat indefinable coloring in the case these authors used for illustration. Finally, they provided the average dimensions of the coloured skin area per perforator, and did not verify the perfusion area of solely the dominant perforator. Hence, no justified conclusion could be drawn regarding the vascular territory of only the dominant perforators. ${ }^{24}$ Finally, Saint-Cyr et al. showed that the venous drainage of a flap based on the second perforator is consistent with the arterial perfusion area and does not impede the size of that flap, in cases where the axiality of anastomoses between the IMAP and the terminal branches of the lateral thoracic and thoracoacromial arteries is respected. ${ }^{20}$

\section{Conclusion}

This study defined that the vascular territory of the dominant IMAP extends from the superior border of the clavicle to the xyphoid, and from mid-sternal to the anterior axial fold. This allows for many different designs of the IMAP flap. We further demonstrated that inclusion of non-dominant perforators does not enlarge the vascular territory. The IMAP flap is sufficiently vascularized by the dominant perforator, making surgery less complex and the risk of donor site morbidity smaller.

\section{Acknowledgment:}

The authors are grateful to Mr. W. J. A. van Wolferen and Mr. S. Plomp from the Department of Pharmacology and Anatomy and to Mr. W.M. Verrijp from the Audiovisual Department at the University Medical Center of Utrecht for their technical assistance. 


\section{References}

1. Palmer JH, Taylor GI. The vascular territories of the anterior chest wall. Br J PlastSurg.139, 287-299, 1986.

2. Joseph J. Nasenplastik und sonstige Gesichtsplastik nebst einem Anhang über Mammaplastik und einige weitere Operationen aus dem Gebiete der aüsseren Körperplastik. Kabitzsch, Leipzig, 1931.

3. Bakamjian VY. A two-stage method for pharyngoesophageal reconstruction with a primary pectoral skin flap. Plast Reconstr Surg. 36, 173-184, 1965.

4. Bakamjian VY Long M Rigg B. Experience with the medially based deltopectoral flap in reconstructuve surgery of the head and neck. Br J Plast Surg. 24, 174-183, 1971.

5. Bakamjian VY. Reconstructive Surgery in Head and Neck Cancer. Radical Neck Dissection.Volume 2. In: Barron JN, Saad MN. Operative Plastic and Reconstructive Surgery. New York: Churchill Livingstone. 1980; pp 479-490.

6. Gilas T, Sako K, Razack MS, Bakamjian VY, Shedd DP, Calamel PM. Major head and neck reconstruction using the deltopectoral flap. A 20 year experience. Am J Surg.152, 430-434, 1986.

7. KrizekTJ, Robson MC. Potential pitfalls in the use of the deltopectoral flap. Plast Reconstr Surg. 50, 326-331, 1972.

8. Mendelson BC, Woods JE, Masson JK. Experience with the deltopectoral flap. Plast Reconstr Surg. 59, 360-365, 1977.

9. Mount DL and Mathes SJ: Neck Reconstruction. In: Mathes SJ, Hentz VR. Plastic Surgery. The Head and Neck. Volume 3, Part 2. Philadelphia: Saunders Elsevier. 2006; pp 1043-1044.

10. Morain WD, Colen LB, Hutchings JC. The segmental pectoralis major muscle flap: a functionpreserving procedure. Plast Reconstr Surg.75, 825-830, 1985.

11. Ariyan $\mathrm{S}$. The pectoralis major myocutaneous flap. A versatile flap for reconstruction in the head and neck. Plast Reconstr Surg. 63, 73-81, 1979.

12. Morain WD, Hallock GG, Morris SF, Neligan PC. Internal Mammary Artery Perforator Flap. In: Perforator Flaps. Anatomy, Technique \& Clinical Applications; Pp 430-439. Blondeel PN, Morris SF, Hallock GG, Neligan PC (ed). Quality Medical Publishing, St Louis MI, 2006.

13. Kalender $V, A y d m ~ H$, Karabulut AB, Ozcan M, Amiraslanov A. Breast reconstruction with the internal mammary artery pedicled fasciocutaneous island flap: description of a new flap. Plast Reconstr Surg. 106, 1494-1498, 2000.

14. Karabulut $A B$, Kalender V. Internal mammary artery pedicled island flap for the treatment of chest wall radionecrosis. Plast Reconstr Surg. 108, 583-584, 2001.

15. Marshall DR. The contralateral breast flap in reconstruction of the breast and chest wall. Ann Plast Surg. 31, 508-513, 1993.

16. Schoeller T, Bauer T, Haug M, Otto A, Wechselberger G, Piza-Katzer H. A new contralateral splitbreast flap for breast reconstruction and its salvage after complication: an alternative for select patients. Ann Plast Surg. 47, 442-445, 2001.

17. Neligan PC, Gullane PJ, Vesely M, Murray D. The internal mammary artery perforatorflap: new variation on an old theme. Plast Reconstr Surg. 119, 891-893, 2007.

18. Vesely MJ, Murray DJ, Novak CB, Gullane PJ, Neligan PC. The internal mammary artery perforator flap: an anatomical study and a case report. Ann Plast Surg. 58, 156-161, 2007.

19. Yu P, Roblin R, Chevray P. Internal mammary artery perforator (IMAP) flap for tracheostoma reconstruction. Head Neck. 28, 723-729, 2006.

20. Saint-Cyr M, Schaverien M, Rohrich RJ. Preexpanded second intercostal space internal mammary artery pedicle perforator flap: case report and anatomical study. Plast Reconstr Surg. 123, 16591664, 2009.

21. Daniel RK, Cunningham DM, Taylor Gl. The deltopectoral flap: an anatomical and hemodynamic approach. Plast Reconstr Surg. 55, 275-282, 1975.

22. Hamdi M, Blondeel $\mathrm{P}$, VanLanduyt $\mathrm{K}$, Monstrey S.: Algorithm in choosing recipient vessels for perforator free flap in breast reconstruction: the role of the internal mammary perforators. $\mathrm{Br} \mathrm{J}$ Plast Surg. 57, 258-265, 2004. 
23. Rosson GD, Holton LH, Silverman RP, Singh NK, Nahabedian MY. Internal mammary perforators: a cadaver study. J Reconstr Microsurg. 21, 239-245, 2005.

24. Schmidt M, Aszmann OC, Beck H, Frey M. The anatomic basis of the internal mammary artery perforator flap: a cadaver study. J Plast Reconstr Aesthet Surg. 63, 191-196, 2010.

25. Schellekens PPA, Hage JJ, Paes EC, Kon M. The internal mammary artery perforator (IMAP) pedicled island flap for reconstruction of the lower head and neck and supraclavicular region: How we do it. Clin Otolaryngol. 35, 327-336, 2010.

26. Schellekens PPA, Paes EC, Hage JJ, Wal van der MBA, Bleys RLAW, Kon M. Anatomy of the vascular pedicle of the internal mammary artery perforator (IMAP) flap as applied for head and neck reconstruction. J Plast Reconstr Aesthet Surg. 64, 53-57, 2011.

27. Munhoz AM, Ishida LH, Montag E, Sturtz, GP, Saito FL, Rodrigues L, Gemperli R, Ferreira MC. Perforator flap breast reconstruction using internal mammary perforator branches as a recipient site: an anatomical and clinical analysis. Plast Reconstr Surg. 114, 62-68, 2004.

28. Sasaki K, Nozaki M, Honda T, Morioka K, Kikuchi Y, Huang T. Deltopectoral skin flap as a free skin flap revisited: further refinement in flap design, fabrication, and clinical usage. Plast Reconstr Surg. 107, 1134-1141, 2001.

29. Boyd JB, Taylor Gl, Corlett R. The vascular territories of the superior epigastric and the deep inferior epigastric systems. Plast Reconstr Surg. 73, 1-16, 1984.

30. Dupin CL, Allen RJ, Glass CA, Bunch R. The internal mammary artery and vein as recipient site for free-flap breast reconstruction: a report of 110 consecutive cases. Plast Reconstr Surg. 98, 685-689, 1996.

31. Blondeel PN. One hundred free DIEP flap breast reconstructions: a personal experience. Br J Plast Surg. 52, 104-111, 1999.

32. Schwabegger AH, Gschnitzer C, Ninkovic MM. Contour deformity at the internal mammary recipient site. Br J Plast Surg. 52, 674, 1999.

33. Conacher ID, Doig JC, Rivas L, Pridie AK. Intercostal neuralgia associated with internal mammary artery grafting. Anaesthesia. 48, 1070-1071, 1993.

34. Defalque RJ, Bromley JJ. Poststernotomy neuralgia: a new pain syndrome. Anesth Anal. 69, 81-82, 1989. 


\section{Chapter 3}




\title{
Anatomy of the vascular pedicle of the internal mammary artery perforator (IMAP) flap as applied for head and neck reconstruction
}

\author{
Pascal P.A. Schellekens \\ Emma C. Paes \\ J. Joris Hage \\ Martijn B.A. van der Wal \\ Ronald L.A.W. Bleys \\ Moshe Kon
}

Presented at the Autumn meeting of the Dutch Society of Plastic and Reconstructive Surgery, October 3, 2009 and at the $21^{\text {th }}$ Annual Meeting of the European Association of Plastic Surgeons, May 27-29, 2010, Manchester, UK.

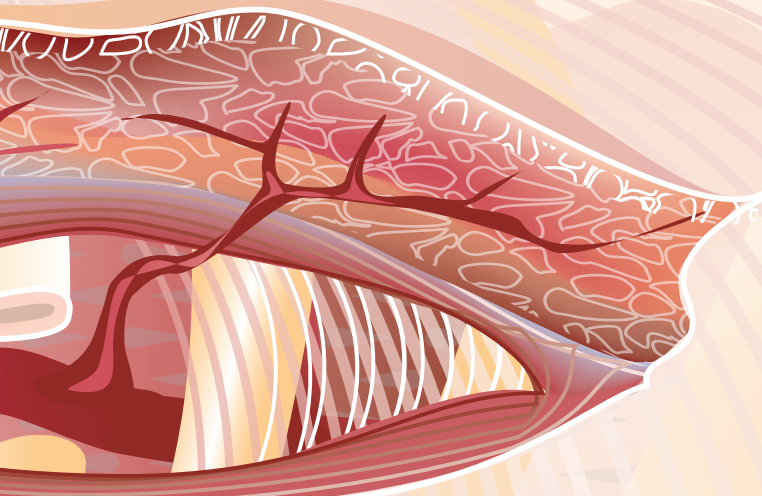




\section{Abstract}

\section{Introduction}

The vascular pedicle of the internal mammary artery perforator (IMAP) flap and its enhancement by inclusion of the internal mammary vessels up to the level of the first rib have not been systematically assessed anatomically, to date. This study assesses these features of this pedicle in light of the flap's application in head and neck reconstruction.

\section{Material and methods}

The length of the IMAP and the enhanced vascular pedicle of the IMAP flap were measured in 27 fresh cadaveric hemi-thoraxes.

\section{Results}

In 18 out of 27 cadaveric cases ( 0.67$)$ the second perforator was dominant. The mean length of the 27 dominant perforators was $47 \mathrm{~mm}$ (range: $30-66 \mathrm{~mm}$ ). By enhancement up to the level of the first rib, the mean length of the vascular pedicle could be doubled to $92 \mathrm{~mm}$ when based on the second perforator $(n=18)$. In the five cases $(0.19)$ where the third perforator was dominant, the mean length of the enhanced pedicle was $104 \mathrm{~mm}$, whereas it was $61 \mathrm{~mm}$ in the four cases (0.15) where the first perforator was dominant.

\section{Conclusion}

This is the first study that assessed the enhanced length of the vascular pedicle of the IMAP flap. Our results show that the mean length of the dominant second perforator may be doubled by such enhancement and that the arc of rotation to the head and neck region may, then, be doubled again. Hereby, even high-located defects in the head and neck region can be reached. This provides a better understanding of the feasibility of the pedicled IMAP flap in head and neck reconstruction. 


\section{Introduction}

The fasciocutaneous internal mammary artery perforator (IMAP) flap that is based on one to three internal mammary artery perforators has been proven a reliable, thin and pliable flap with a suitable arc of rotation and perfect colour match for head and neck and other regional reconstructions. ${ }^{1-7}$ There is general agreement on the dominancy of one perforator $^{8-11}$ that is preferably used for the pedicle of this flap. The flap's pedicle may be lengthened by inclusion of part of the internal mammary (IM) vessels that, additionally, feature a larger diameter than the perforating vessels. Such enhancement of the pedicle allows for more cranial recipient sites to be reached using pedicled IMAP flaps, as well as for easier planning and anastomosing of free IMAP flaps. ${ }^{12}$

Although the diameter of the perforating branches of the IM vessels have been repeatedly studied, ${ }^{8,10,11,13}$ the length of these perforators and its enhancement by inclusion of part of the IM vessels have, to date, not been systematically assessed anatomically. ${ }^{12}$ The aim of this study was to assess these as yet insufficiently explored features of this pedicle in light of the flap's application in head and neck reconstruction.

\section{Material and Methods}

In nine male and five female fresh cadavers (mean age, 76 years) anterior hemithoracic fasciocutaneous flaps were dissected bilaterally. Because of previous cardiac surgery only one flap could be dissected in one cadaver. The dissection was performed laterally to medially in a subfascial plane until the perforators were visualized. Using $3 x$ magnification, the dominant IMAP and its comittant vein(s) were located. ${ }^{16}$ Subsequently, the pectoralis major and intercostal muscles were dissected and part of the costal cartilage of one or two ribs immediately cranial to this perforator was resected (Figure 1). Only the cartilage of the second rib was resected in cases where the second perforator was dominant, whereas the cartilages of both the second and third rib were resected in cases where the third perforator was dominant. To warrant thoracic stability neither any costal cartilage, nor any part of the clavicle was resected in cases where the first perforator was found to be dominant. Still, the intercostal muscle of the first intercostal space was dissected and, thus, the caudal border of the cartilage of the first rib became the pivot point of the flaps' vascular pedicle in all cases. 


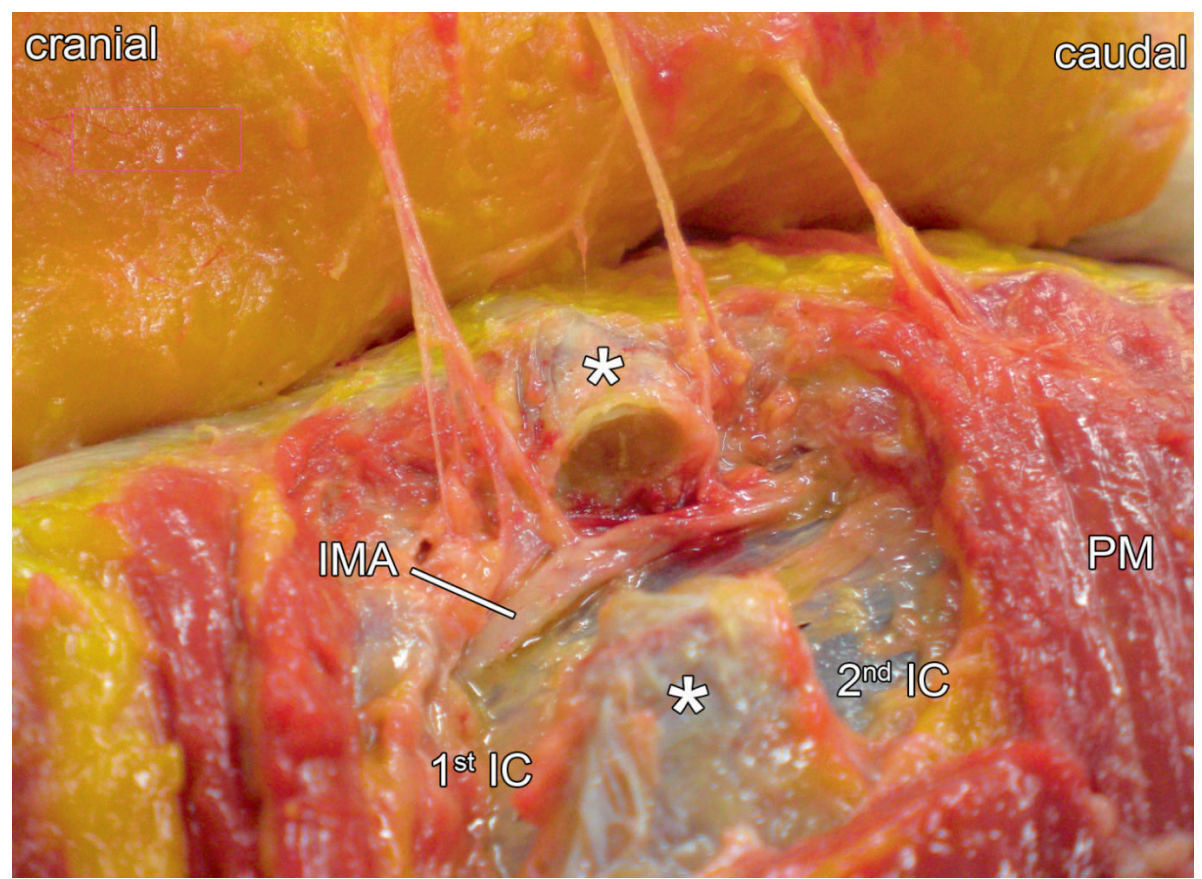

Figure 1: In this case the costal cartilage of the second rib was removed (marked with an asterisk), depending on the origination of the dominant perforator at this right side. IC: intercostal space; IMA: internal mammary artery. PM: pectoralis major muscle.

The length of the dominant perforator was measured from its branching point of the IM vessels up to its entrance in the fascia of the flap (Figure $2 \mathrm{~A}$ ). The pedicle's additional length provided by dissection of the IM vessels was measured from the branching point up to the caudal border of the first costal cartilage (Figure 2B). Hence, the enhanced vascular pedicle length was defined as the length of the dominant perforator plus the additional length provided by the IM vessels up to the level of the first costal cartilage. 

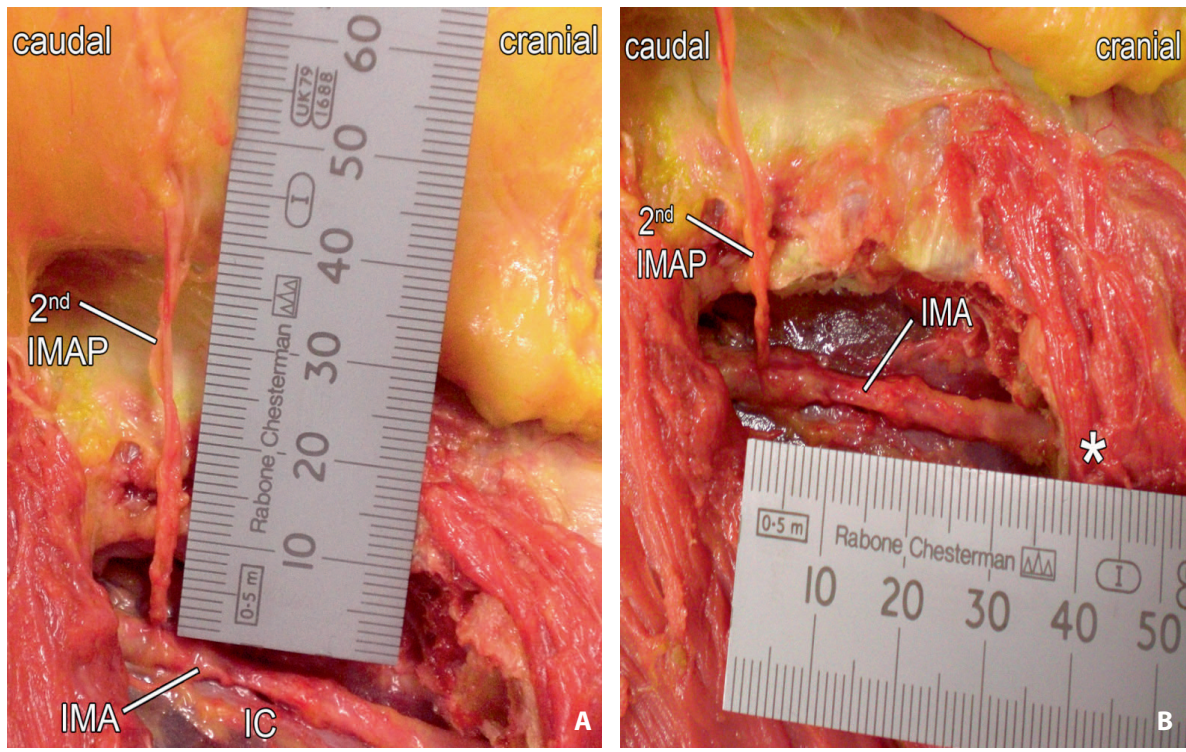

Figure 2: The length of the enhanced vascular pedicle length was defined as the length of the dominant perforator (A) plus the additional length provided by the IM vessels up to the level of the first costal cartilage (marked with an asterisk) (B). Note that the perforator of the second intercostal space is the dominant perforator in this case. IMAP: internal mammary artery perforator, IMA: internal mammary artery. IC: intercostal space

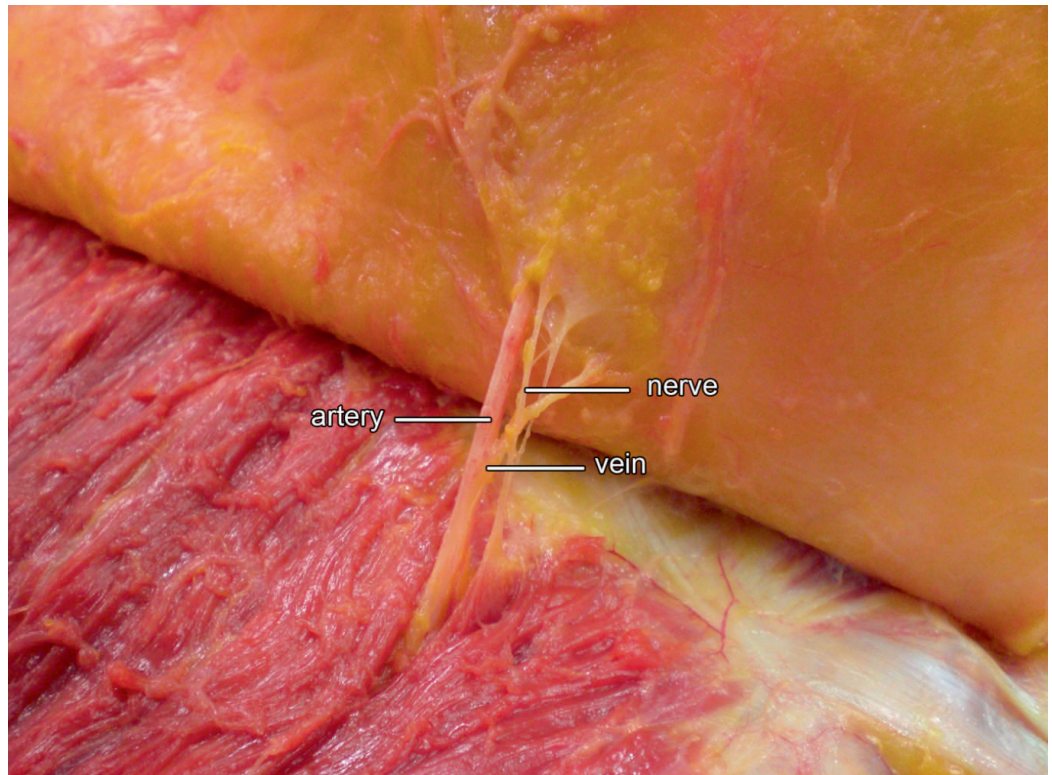

Figure 3: The vascular pedicle was accompanied by an individual nerve branch of the intercostal nerves, in all cases. 


\section{Results}

In 18 of the 27 cases $(0.67)$, the dominant perforator was located in the second intercostal space, whereas the third perforator was dominant in five cases (0.19), and the first in four cases (0.15) (Table 1). The mean length of the 27 dominant perforators was $47 \mathrm{~mm}$ (range: 30 - $66 \mathrm{~mm}$ ). We found all perforators to be accompanied by an individual anterior nerve branch of the intercostal nerves (Figure 3).

The mean length of the enhanced vascular pedicle was $92 \mathrm{~mm}$ (range: 75 - 103) in cases where the second perforator was dominant, whereas it was $104 \mathrm{~mm}$ (range: 83 - 123 $\mathrm{mm}$ ) in cases with a dominant third perforator, and $61 \mathrm{~mm}$ (range: $53-69 \mathrm{~mm}$ ) if the first perforator was found to be dominant.

Table 1: Bilateral vascular pedicle length of the dominant perforators in 14 fresh cadavers

\begin{tabular}{lcccc}
\hline $\begin{array}{l}\text { Side of } \\
\text { Cadaver }\end{array}$ & $\begin{array}{c}\text { Dominant } \\
\text { perforator }\end{array}$ & $\begin{array}{c}\text { Length of } \\
\text { perforator }(\mathrm{mm})\end{array}$ & $\begin{array}{c}\text { Length of } \\
\text { IM vessels }(\mathrm{mm})\end{array}$ & $\begin{array}{c}\text { Enhanced pedicle } \\
\text { length }(\mathrm{mm})\end{array}$ \\
\hline 1 right* & 2 & 50 & 45 & 95 \\
2 right & 2 & 66 & 42 & 104 \\
2 left & 2 & 34 & 50 & 84 \\
3 right & 3 & 42 & 65 & 107 \\
3 left & 2 & 63 & 35 & 98 \\
4 right & 3 & 49 & 58 & 107 \\
4 left & 3 & 57 & 66 & 123 \\
5 right & 1 & 36 & 17 & 53 \\
5 left & 1 & 35 & 20 & 55 \\
6 right & 2 & 47 & 44 & 91 \\
6 left & 2 & 46 & 40 & 86 \\
7 right & 2 & 47 & 57 & 104 \\
7 left & 2 & 42 & 55 & 97 \\
8 right & 3 & 48 & 54 & 97 \\
8 left & 2 & 50 & 50 & 100 \\
9 right & 2 & 49 & 37 & 86 \\
9 left & 2 & 51 & 38 & 89 \\
10 right & 2 & 50 & 53 & 103 \\
10 left & 2 & 46 & 48 & 94 \\
11 right & 3 & 48 & 35 & 83 \\
11 left & 2 & 44 & 31 & 75 \\
12 right & 2 & 31 & 46 & 77 \\
12 left & 2 & 30 & 45 & 75 \\
13 right & 1 & 45 & 20 & 65 \\
13 left & 1 & 47 & 22 & 101 \\
14 right & 2 & 53 & 46 & 97 \\
14 left & 2 & 51 & &
\end{tabular}

* only one side was measured because of prior heart surgery 


\section{Discussion}

The IMAP flap has been proven to be a reliable flap that is perfectly suitable to cover defects in the head and neck region. $3,4,6,7,14$ The vascular pedicle of the IMAP flap may exclusively consist of the dominant perforator ${ }^{6,7,14}$ but, in most clinical cases, one 1,2, ${ }^{4,5}$ or more ${ }^{3}$ non-dominant perforators are additionally included. We chose to assess the non-enhanced and enhanced pedicle length of solely the dominant perforators, because these perforators were previously found most relevant to the vascular territory of the IMAP flap. ${ }^{15}$

In most cases of application of IMAP flaps for head and neck reconstruction reported to date, part of the costal cartilage of the second, ${ }^{6}$ third rib, ${ }^{3}$ or both these ribs ${ }^{4}$ was resected to improve the flap's arc of rotation. So far, only Yu et al.? reported on two patients in whom a flap based on the dominant second perforator was used without enhancement by resection of costal cartilage. Both flaps were applied for closure of adjacent irradiated tracheostoma defects that could easily be covered without tension on the flap's vascular pedicle. Neligan et al. ${ }^{4}$ reported on an IMAP flap pedicled on the second and third perforator. To allow subcutaneous tunnelling of their flap to its recipient site, these authors resected the costal cartilage between the two perforators and transected the IM vessels distally to the perforator. Vesely et al. ${ }^{6}$ reported on a case of a bilateral pedicled IMAP flap based on the second dominant perforator. They, too, divided the second costal cartilage to enhance coverage of the whole anterior neck with the flap. Finally, Morain et al. $^{3}$ resected the cartilage of the second and also the third rib to allow coverage of a pharyngeo-oesophagectomy defect by a vertically orientating IMAP flap based on the first three perforators. The results of these studies illustrate that including a segment of the IM vessels by resection of the costal cartilage cranially to its dominant perforator brought the rotation point of the vascular pedicle more cranial. This leads to an increased arc of rotation and easier mobilisation of the flap and, thus, improves the applicability of the IMAP flap in relatively cranially located defects in the head and neck region. Only very recently Saint-Cyr and co-workers reported pre-expanding the IMAP flap, thereby improving its arc of rotation. ${ }^{14}$

In the current cadaver study, we found the dominant perforator to be located in the second intercostal space in two-third, and in the third intercostal space in onefifth of our cases. This is in line with most other studies that assessed the location ${ }^{13}$ and dominance ${ }^{8-11}$ of these perforators. We showed that the average pedicle length consisting solely of the dominant perforator is $47 \mathrm{~mm}$ (range: $30-66 \mathrm{~mm}$ ). This compares to the mean intraoperatively measured length of $35 \mathrm{~mm}$ (range: 18 - $48 \mathrm{~mm}$ ) of the dominant perforator in seven patients, who underwent a free deltopectoral skin 
flap. ${ }^{12}$ Schmidt et al. ${ }^{11}$ reported a mean length of $83 \mathrm{~mm} \pm 36 \mathrm{~mm}$ (range: $30-170 \mathrm{~mm}$ ) of the perforators in 10 fresh cadavers but it remained unclear between which points they measured. Hence, no comparison with our results can be made.

We, furthermore, assessed the increase of length of the flap's vascular pedicle by inclusion of the IM vessels up to the level of the first costal cartilage. The mean length of the dominant second perforator thus enhanced measured $92 \mathrm{~mm}$, or nearly twice the length of the non-enhanced perforator $(47 \mathrm{~mm})$. In cases where the third perforator was dominant, enhancement even increased the mean pedicle length with almost $125 \%$ (104 mm vs. $47 \mathrm{~mm}$ ). The clinical gain for head and neck reconstructions is, again, doubled as the pivot point of the arc of rotation thus increased is brought up more cranially. Still, obtaining such maximum enhancement requires resection of cartilage of the second and the third rib and of the associated pectoralis major and intercostal muscular tissue. In cases where the first IMAP is dominant, the mean length of the vascular pedicle may only be increased from $47 \mathrm{~mm}$ to $61 \mathrm{~mm}$ by the dissection of the $\mathrm{IM}$ vessels and their transection distally to the perforator. Yet, such a pedicle is closer to the head and neck region and, therefore, no costal cartilage has to be resected to allow the flap to reach this region. These observations seem to be in accordance with the clinical experience of Sasaki et al. ${ }^{12}$ who were able to lengthen the pedicle of a free deltopectoral skin flap from a mean of $35 \mathrm{~mm}$ (range: 18 - $48 \mathrm{~mm}$ ) in 7 non-enhanced cases, to a mean of $52 \mathrm{~mm}$ (range: 35 - $72 \mathrm{~mm}$ ) in 20 enhanced cases. ${ }^{12}$ Because these authors did not report the level of dissection of the IM vessels, nor which perforator they included, no further comparison with our results can be made.

When planning an IMAP flap, the perforator and IM vessels of the right side of the thorax are preferably used to spare the IM vessels of the left side for possible future cardiac surgery. ${ }^{10,13,16}$ Preoperative mapping of the perforators is advised, using Duplex or Doppler investigation. ${ }^{3,6,7,11}$ Of these, Duplex or radiological imaging techniques offer the additional advantage of preoperative localization of the dominant IMAP. Using a lateral approach, the dominant perforator is found approximately $10-23 \mathrm{~mm}$ lateral to the sternum boarder, depending on the level of this perforator. ${ }^{17}$ It is easily recognized as dominant relative to the other perforators since its diameter is twice as large in $85 \%$ of cases. ${ }^{9}$ As every perforator bundle is accompanied by an individual anterior branch of the intercostal nerve this offers opportunity of a sensate pedicled flap in cases where the pedicle length does not need to be enhanced (Figure 3). When enhancing the vascular pedicle by resection of the costal cartilage cranial to the perforator, the close relation of the perforators to the cartilage anteriorly and the pleura posteriorly should be reckoned with. Although none of these complications occurred in the cases of IMAP flaps reported to date,,$^{3,4,6}$ pneumothorax, ${ }_{1}^{18}$ contour deformity of the thorax, $^{19,20}$ 
and intercostal neuralgie ${ }^{21,22}$ have been reported as sequelae of such resection. After mobilization of the vascular pedicle, the flap and its pedicle may be subcutaneously tunnelled towards the defect. ${ }^{4,7}$

This is the first study that assessed detailed information on the enhanced length of the vascular pedicle of the IMAP flap by incorporating the IM vessels and their perforating branches. Our results show that the mean length of the dominant second IMAP may usually be doubled by such enhancement. Because the arc of rotation is brought more cranially this way the clinical gain by enhancement is again doubled. These results provide a better understanding of the feasibility of the pedicled IMAP flap in head and neck reconstruction.

\section{Acknowledgements}

The authors thank Mr. W. J. A. van Wolferen and Mr. S. Plomp from the department of Pharmacology and Anatomy and Mr. W.M. Verrijp from the Audiovisual department of the University Medical Centre Utrecht, for their technical assistance. None of the authors has a financial interest in any of the products, devices or drugs mentioned in the article. 


\section{References}

1. Kalender $\mathrm{V}, \mathrm{Aydm} \mathrm{H}$, Karabulut $\mathrm{AB}, \mathrm{Ozcan} \mathrm{M}$, Amiraslanov A. Breast reconstruction with the internal mammary artery pedicled fasciocutaneous island flap: description of a new flap. Plast Reconstr Surg.106: 1494-1498, 2000.

2. Karabulut $A B$, Kalender V. Internal mammary artery pedicled island flap for the treatment of chest wall radionecrosis. Plast Reconstr Surg. 108: 583-584, 2001.

3. Morain WD, Hallock GG, Neligan PC. Internal Mammary Artery Perforator Flap,Pp 430-439. In Perforator Flaps. Anatomy, Technique \& Clinical Applications. Blondeel PN, Morris SF, Hallock GG, Neligan PC (ed). Quality Medical Publishing, St Louis MI, 2006.

4. Neligan PC, Gullane PJ, Vesely M, Murray D. The internal mammary artery perforator flap: new variation on an old theme. Plast Reconstr Surg.119, 891-893, 2007.

5. Schoeller T, Bauer T, Haug M, Otto A, Wechselberger G, Piza-Katzer H. A new contra-lateral splitbreast flap for breast reconstruction and its salvage after complication: an alternative for select patients. Ann Plast Surg. 47, 442- 445, 2001.

6. Vesely MJ, Murray DJ, Novak CB, Gullane PJ, Neligan PC. The internal mammary artery perforator flap: an anatomical study and a case report. Ann Plast Surg. 58, 156-161, 2007.

7. $\mathrm{Yu}$ P, Roblin P, Chevray P. Internal mammary artery perforator (IMAP) flap for tracheostoma reconstruction. Head Neck. 28, 723-729, 2006.

8. Hamdi M, Blondeel PN, VanLanduyt K, Monstrey S. Algorithm in choosing recipient vessels for perforator free flap in breast reconstruction: the role of the internal mammary perforators. $\mathrm{Br} J$ Plast Surg. 57: 258-265, 2004.

9. Palmer JH, Taylor GI. The vascular territories of the anterior chest wall. Br J Plast Surg. 39, 287-299, 1986.

10. Rosson GD, Holton LH, Silverman RP, Singh NK, Nahabedian MY. Internal mammary perforators: a cadaver study J Reconstr Microsurg. 21, 239-242, 2005.

11. Schmidt M, Aszmann OC, Beck H, Frey M. The anatomic basis of the internal mammary artery perforator flap: a cadaver study. J Plast Reconstr Aesthet Surg. 63,191-196, 2010.

12. Sasaki K, Nozaki M, Honda T, Morioka K, Kikuchi Y, Huang T. Deltopectoral skin flap as a free skin flap revisited: further refinement in flap design, fabrication, and clinical usage. Plast Reconstr Surg. 107, 1134-1141, 2001.

13. Munhoz AM, Ishida LH, Montag E, Sturtz GP, Saito FL, Rodrigues L, Gemperli R, Ferreira MC. Perforator flap breast reconstruction using internal mammary perforator branches as a recipient site: an anatomical and clinical analysis. Plast Reconstr Surg. 114, 62-68, 2004.

14. Saint-Cyr M, Schaverien M, Rohrich RJ. Preexpanded second intercostal space internal mammary artery pedicle perforator flap: case report and anatomical study. Plast Reconstr Surg. 123,16591664, 2009.

15. Paes EC, Schellekens PPA, Hage JJ, Wal vd MBA, Bleys RLAW, Kon M. A cadaver study of the vascular territories of dominant and non-dominant internal mammary artery perforators. Ann Plast Surg. 67, 68-72, 2011.

16. Haywood RM, Raurell A, Perks AG, Sassoon EM, Logan EM, Phillips J. Autologous free tissue breast reconstruction using the internal mammary perforators as recipient vessels.Br J Plast Surg. 56: 689691, 2003

17. Hefel L, Schwabegger A, Ninkovic M, Wechselberger G, Moriggl B, Waldenberger P, Anderl H. Internal mammary vessels: anatomical and clinical considerations. Br J Plast Surg. 48: 527- 532, 1995.

18. Dupin $C L$, Allen $\mathrm{RJ}$, Glass $C A$, Bunch $\mathrm{R}$. The internal mammary artery and vein as a recipient site for free-flap breast reconstruction: a report of 110 consecutive cases. Plast Reconstr Surg. 98: 685-689, 1996.

19. Blondeel PN. One hundred free DIEP flap breast reconstructions: a personal experience. Br J Plast Surg. 52, 104-111,1999. 
20. Schwabegger AH, Gschnitzer C, Ninkovic MM. Contour deformity at the internal mammary recipient site. Br J Plast Surg. 52, 674, 1999.

21. Conacher ID, Doig JC, Riva L, Pridie AK. Intercostal neuralgia associated with internal mammary artery grafting. Anaesthesia 48, 1070-1071, 1993.

22. Defalque RJ, Bromley JJ. Poststernotomy neuralgia: a new pain syndrome Anesth. Analg. 69, 81-82, 1989. 


\section{Chapter 4}




\section{Key points}

- Like some other regional flaps, the internal mammary artery perforator pedicled island flap provides a thin and pliable skin flap of good colour match.

- Contrary to other regional flaps, however, the parasternal donor region of the internal mammary artery perforator flap allows for primary closure of the donor site of relatively large flaps and, hence, for limited donor site morbidity.

- Parasternal enhancement of the vascular pedicle results in a mean increase of the length of the vascular pedicle of $4.7 \mathrm{~cm}$ and, consequently, to double that increase of the reach of the flap in the lower head and neck receptor region.

- Our experience in seven clinical cases illustrates this enhanced perforator flap to be a consistently successful alternative in oncologic reconstructive surgery, allowing for superior aesthetical and functional skin cover. 


\section{Introduction}

Based on our anatomical assessment of the vascular pedicle of the internal mammary artery perforator (IMAP) flap, we previously concluded that this flap is well suited for the reconstruction of head and neck defects. ' Like other regional skin flaps such as the deltopectoral flap and the supraclavicular flap, ${ }^{2}$ the IMAP flap provides skin cover with superior colour match in the head and neck receptor region. Unlike the (segmental) pectoralis major myocutaneous flap, ${ }^{3}$ however, this flap is thin and pliable, adapting easily to the subtle contour and mobility of the suprasternal and maxillofacial structures. Additionally, the IMAP flap leads to limited morbidity and its donor site may be closed primarily in most cases.

Lately, we routinely used the IMAP flap for superior receptor and donor site characteristics in cases where no additional bulk was required. By presenting this clinical series, we intend to emphasize and illustrate the versatility and consistency of this flap for reconstruction of the lower head and neck region.

\section{Patients}

From November 2007 to April 2009, we applied an IMAP pedicled island flap in one female and six male oncologic patients with a mean age of 57 years (Table 1). The flap was used to primarily close defects after resection of a primary tumour (Cases A, F and $G$ ) or a recurrent or metastatic tumour (Cases $C, D$ and $E$ ), or defects resulting from previous radiotherapy (Case $\mathrm{B}$ ). Currently, the follow-up on these seven patients ranges from 9 to 22 months (mean, 11 months).

\section{Ethical Considerations}

Informed consent was obtained from all patients involved and treatment was executed in accordance with the Good Clinical Practice (GCP) standard provided by the International Conference on Harmonisation $(\mathrm{ICH})$. As this was an assessment of a documented innovative surgical technique, no formal approval of the Local Research Ethics Committee was sought. Our reporting conforms to the actual version of the ethical standards according to the Declaration of Helsinki, first published in 1964. 


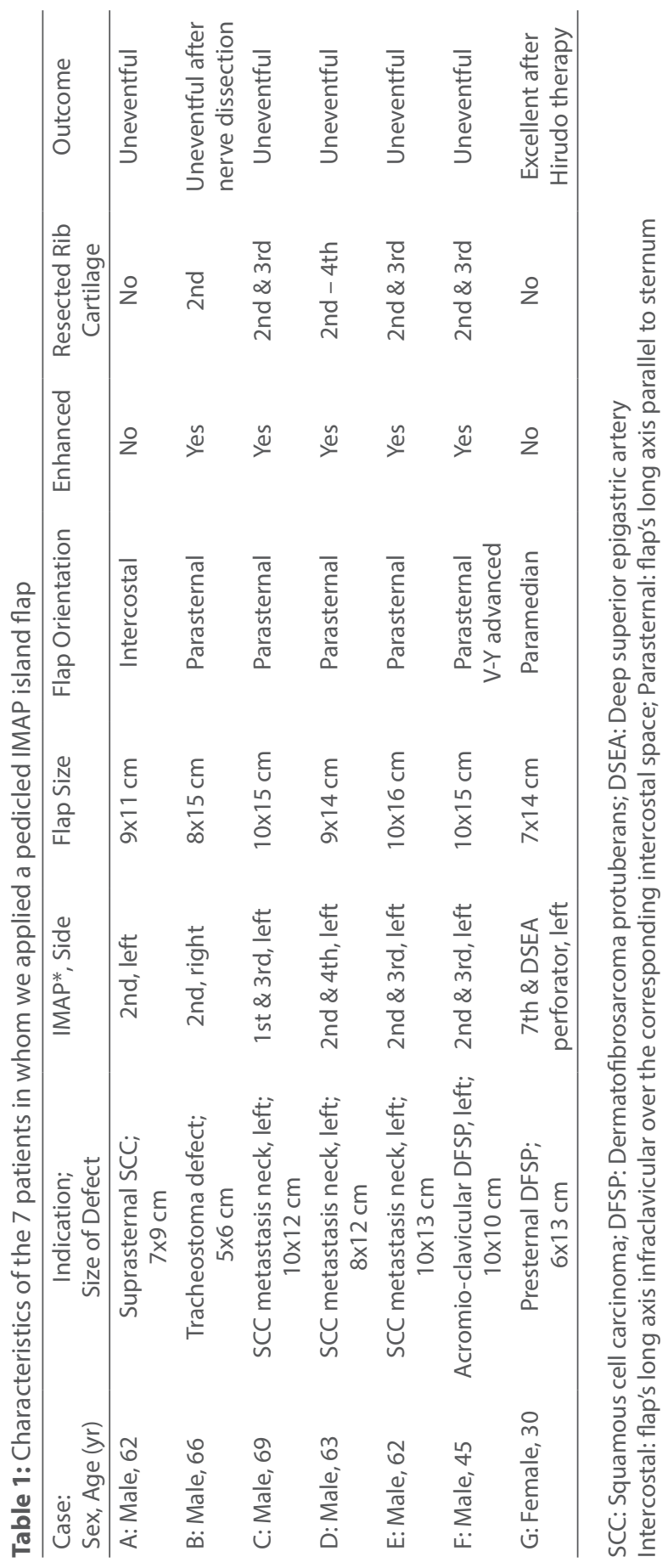




\section{Surgical Technique}

Preoperatively, the dominant IMAP was bilaterally detected on the basis of the strongest signal of a hand-held Doppler auscultatory device. ${ }^{4}$ Including this IMAP, the island flap was designed with its long axis orientated parasternally $(n=6)$ or parallel to the corresponding intercostal space $(n=1)$, and in accordance to the size of the defect (Fig. 1A). Care was taken not to extend the design over the anterior axillary fold laterally. ${ }^{5,6}$ Peroperatively, the initial incision was made at the medial border of the flap to proceed laterally in a subfascial plane until the selected IMAP was visualized. ${ }^{4}$ The degree of perfusion of the perforators was once more assessed by Doppler to assure the dominancy of this IMAP., 7 Subsequently, the flap was circumferentially incised and raised from its distal edge toward the IMAP, turning it into a true island flap. In five of our cases, the origin of the perforating vascular pedicle at the internal mammary artery and vein was dissected by parasternal splitting of the adjacent pectoralis major muscle fibers and resection of the intercostal muscles. To obtain a better view of the course of the internal mammary artery and vein, as well as to enhance the length of the vascular pedicle, the cartilage of the rib(s) immediately cranially to the IMAP was removed in these patients (Table 1)., 5,7 The internal mammary artery and vein were clipped and divided immediately distally to the origin of the most caudal perforator and dissected up to the caudal border of the first costal cartilage (Fig. 1B). 5, 7,8 This mobilization of the vascular pedicle led to a mean increase of the length of the vascular pedicle of $4.7 \mathrm{~cm}$ (range, $1.7-5.0 \mathrm{~cm}$ ) and, consequently, to double that increase of the arc of rotation of the flap in cranial direction.

In three of our seven patients, the flap and vascular pedicle were subcutaneously tunnelled to the defect. ${ }^{4,7}$ The soft tissue defect resulting from cartilage resection and muscle splitting was obliterated by suturing of the pectoral muscle to the lateral edge of the sternum. ${ }^{9}$ In all cases, the donor site could be closed primarily without need of a skin graft (Fig. 1C). 


\section{Figure 1}
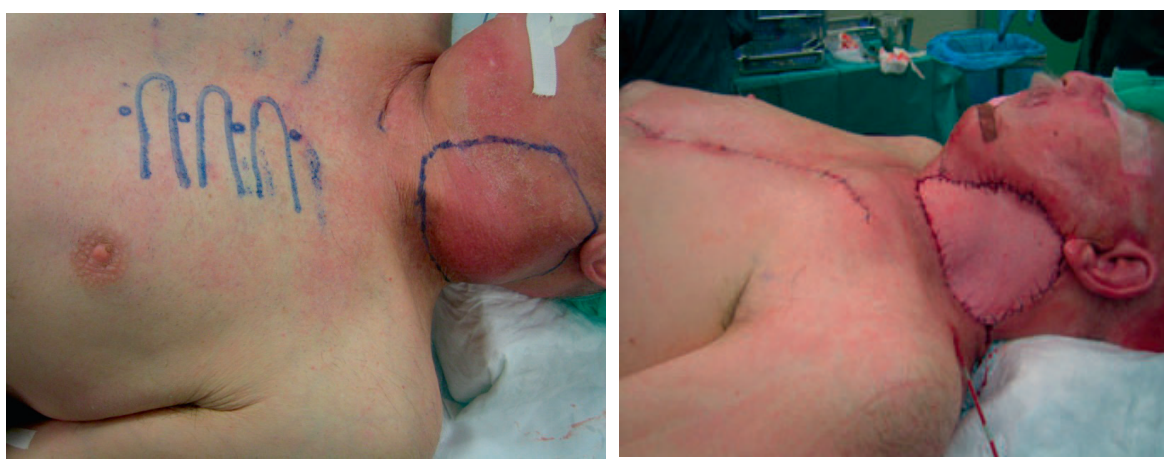

A

C
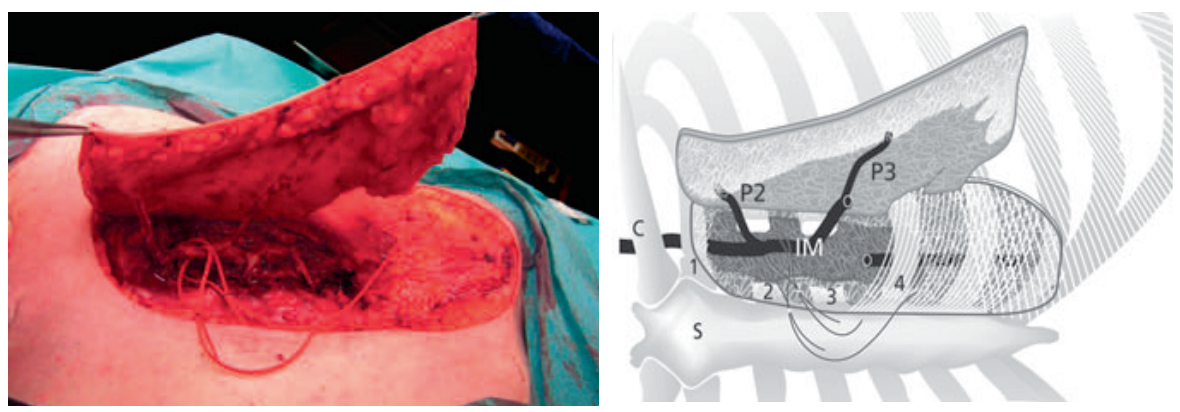

B

$\mathrm{B}^{\prime}$

A: A 62-year-old man (Case E) had previously undergone combined chemo-radiotherapy for T2N3M0 hypopharynxcarcinoma but presented with a large metastasis of a squamous cell carcinoma in his left neck, 8 months after. The $10 \times 13 \mathrm{~cm}$ skin area to be resected along with palliative unilateral lymph node dissection and the location of the Doppler signal of the left-sided IMAPs were marked pre-operatively.

B-left: An IMAP flap $(10 \times 16 \mathrm{~cm})$ based on the left second and third intercostal perforating vessels was raised parasternally. Resection of the second and third rib cartilage and intermediate intercostal muscles allowed distal clipping of the internal mammary vessels to enhance the pedicle length. Please, note that this photo was taken from the right side of the patient, locating his neck at the left side of the photo.

B-right: Schematic drawing of the flap. C: Left clavicula; S: Sternum; IM: Internal mammary vessels; P2 and P3: Second and third internal mammary perforators, respectively; 1 and 4: First and fourth rib, respectively; 2 and 3 : Cartilage stumps of second and third ribs, respectively.

C: Immediate postoperative result after primary closure of the donor site in the same patient. 


\section{Results}

The vascular pedicle of one patient (Case B) was explored shortly after wound closure because of venous congestion of the flap. The intercostal nerve accompanying the pedicle was found to obliterate the perforating vein and was dissected. Subsequent healing was uneventful. In another patient (Case G), we applied medical leeches for three days to resolve some venous congestion. ${ }^{5}$ This flap, too, healed uneventful afterwards.

Three of the IMAP flaps (Cases D, F and G) were subjected to adjuvant radiotherapy without problem. The flap's colour match did not deteriorate from it (Fig. 2). This match was less in the one patient (Case E) in whom the receptor site had been irradiated, six months prior to surgery. In the one female patient, the flap could be thinned out uneventfully and successfully by liposuction, 8 months after transplantation.

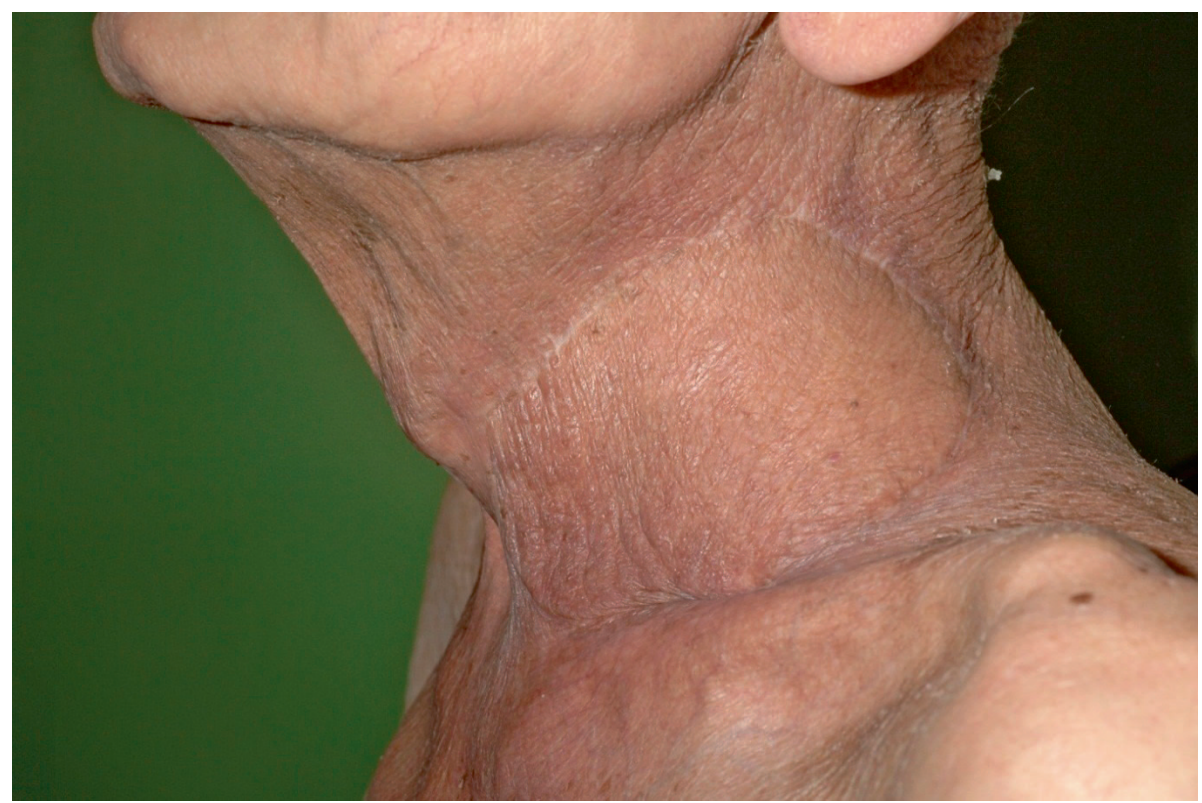

Figure 2: Result in a 63-year-old male who underwent lymph node dissection and a $12 \times 8 \mathrm{~cm}$ skin resection for squamous cell carcinoma metastasis, 3 months after adjuvant radiotherapy (Case D). Please, note that the flap's colour match remained excellent. 


\section{Discussion}

To cover defects in the head and neck region, thin, non-hirsute flaps with good colour and texture match are to be used for optimal aesthetic and functional results. These flaps ought to adapt easily to the normal, subtle contours and should prevent any restriction of range of motion of this region. More often than not, local flaps are not sufficiently available after oncologic treatment and, in these cases, regional skin flaps may best address the requirements. ${ }^{2,4,6,8,10}$

In 2006, Morain et al. were the first to illustrate the use of an IMAP flap. ${ }^{8}$ In the same year, Yu et al. ${ }^{4}$ reported on two clinical cases to be followed again shortly after by Neligan's group from Toronto, Canada, who reported on two additional cases and an anatomical study. ${ }^{5,7}$ Recently, Saint-Cyr et al. ${ }^{6}$ reported a sixth case in whom the IMAP flap was preexpanded and lyer et al. added another three cases. ${ }^{11}$ Like us, all these authors found the IMAP island flap to address the aesthetic and functional requirements. Inclusion of more than one perforator or pre-expansion allowed for large flaps to be raised and bilateral use of these flaps allowed for even larger defects to be covered. ${ }^{5,6}$ The donor scar may be orientated overlying the intercostal space ${ }^{4,5}$ or parasternally, ${ }^{7,8}$ in accordance with individualized aesthetic requirements. Contrary to the supraclavicular donor area of the deltopectoral flap, all infraclavicular donor sites of our IMAP flaps could be closed primarily without the need of a skin graft. No dog ears were observed and subcutaneous tunnelling of the flap's pedicle may reliably prevent the donor scar to cross the clavicle. Use of more inferiorly selected perforators (Case G) allowed for coverage of presternal defects with an even less conspicuous donor scar and enhancement of the vascular pedicle by partial dissection of the internal mammary vessels allowed for more distant recipient sites to be reached by this pedicled flap., ${ }^{1,5,7,8}$

The IMAP flap lacks the disadvantages of the (segmental) pectoralis major myocutaneous flap ${ }^{3}$ such as its bulky aspect, functional impairment, contour deficits, or skin paddle necrosis. The only alternative regional skin flap not leaving a conspicuous scar might be the tunnelled supraclavicular island flap pedicled on the transverse cervical artery and vein. ${ }^{2}$ Still, unlike the IMAP island flap, this flap may not be useful in head and neck cancer patients who have undergone radical neck dissection or (neo-)adjuvant radiotherapy. With these dissections, the vascular pedicle of the supraclavicular flap is usually severed with the lymph node dissection, whereas radiation may potentially damage the pedicle and hamper primary closure and healing of the donor site. ${ }^{10}$ 
We have accepted the IMAP island flap as a valuable addition to the variety of reconstructive tools for the head and neck region. That the IMAP island flap has, so far, not gained widespread application may be explained by its being relatively unknown and possibly neglected for its assumed technical complexity. It is true that not all reconstructive head and neck surgeons are familiar and comfortable with an anatomical area that is well known to breast reconstructive surgeons. Enhancing the length of its pedicle and the arc of rotation by distal division of the internal mammary vessels necessitates dissection of the pectoralis major and intercostals muscles and removal a part of the costal cartilages. This may cause postoperative contour deformity of the thorax, intercostal neuralgia, pneumothorax, or wound healing problems. ${ }^{1}$ Even though such complications were not seen in our series, nor described in the previous case reports, ${ }^{4,5,7,8}$ some additional measures may need be taken to prevent them. As such, we limited the resection of rib cartilage and intercostal muscles muscle and reattached the pectoralis major muscle to the sternum to avoid potential deformity. ${ }^{9}$ Additionally, we prefer a right-sided IMAP in cases where median defects leave a choice between a left and right IMAP flap, in order to save the left-sided internal mammary for possible future cardiac surgery. ${ }^{6,9}$

\section{Conclusions}

In the largest clinical series of its type presented to date, we showed the IMAP flap to be a consistently successful alternative for various reconstructions in the lower head and neck region. Like some other regional flaps, the IMAP flap provides a large, thin and pliable skin flap of good colour match based on a reliable vascular pedicle that permits a large arc of rotation when enhanced. Contrary to other regional flaps, however, the associated donor site morbidity and disfigurement is limited. 


\section{References}

1. Schellekens PPA, Paes EC, Hage JJ, Wal van der MBA, Bleys RLAW, Kon M. Anatomy of the vascular pedicle of the internal mammary artery perforator (IMAP) flap as applied for head and neck reconstruction. J Plast Reconstr Aesthetic Surg 64, 53-72, 2011.

2. Pallua N, Magnus Noah E. The tunneled supraclavicular island flap: an optimized technique for head and neck reconstruction. Plast Reconstr Surg.105, 842-851, 2000.

3. Corten EML, Schellekens PPA, Hage JJ, Kon M. Clinical outcome after pedicled segmental pectoralis major island flaps for head and neck reconstruction. Ann Plast Surg. 63, 292-296, 2009.

4. $\mathrm{Yu}$ P, Roblin $\mathrm{P}$, Chevray P. Internal mammary artery perforator (IMAP) flap for tracheostoma reconstruction. Head Neck. 28, 723-729, 2006.

5. Vesely MJ, Murray DJ, Novak CB, Gullane PJ, Neligan PC. The internal mammary artery perforator flap: an anatomical study and a case report. Ann Plast Surg. 58, 156-161, 2007.

6. Saint-Cyr M, Schaverien M, Rohrich RJ. Preexpanded second intercostal space internal mammary artery pedicle perforator flap: case report and anatomical study. Plast Reconstr Surg. 123, 16591664, 2009.

7. Neligan PC, Gullane PJ, Vesely M, Murray D. The internal mammary artery perforator flap: new variation on an old theme. Plast Reconstr Surg.119: 891-893, 2007.

8. Morain WD, Hallock GG, Neligan PC. Internal mammary artery perforator flap. In Blondeel PN, Morris SF, Hallock GG, Neligan PC, eds. Perforator Flaps - Anatomy, Technique \& Clinical Applications. St. Louis, Missouri: Quality Medical Publishing, 2006. pp. 429-439.

9. Hamdi M, Blondeel P, Van Landuyt K, Monstrey S. Algorithm in choosing recipient vessels for perforator free flap in breast reconstruction: the role of the internal mammary perforators. $\mathrm{Br} \mathrm{J}$ Plast Surg. 57, 258-265, 2004.

10. Cordeiro PG. Discussion - The tunneled supraclavicular island flap: an optimized technique for head and neck reconstruction. Plast Reconstr Surg.105, 852-854, 2000.

11. Iyer NG, Clark JR, Ashford BG. Internal mammary artery perforator flap for head and neck reconstruction. ANZ J Surg. 79, 799-803, 2009. 


\section{Addendum}

\section{Case A}

A 62-year-old man presented with a presternal exophytic growing squamous cell carcinoma with a diameter of $4.5 \mathrm{~cm}$. The tumour was excised with $1.5 \mathrm{~cm}$ margin together with a part of the sternocleidomastoid muscle and the anterior cortex of the manubrium which resulted in a defect of $7 \times 9 \mathrm{~cm}$. Adjacent to the defect an internal mammary artery perforator in the left second intercostal space was traced by a handheld Doppler auscultatory device. A $9 \times 11 \mathrm{~cm}$ IMAP flap was designed on the lateral thoracic wall with the perforator on the medial border of the flap. After identification of the perforator the flap was dissected in a subfascial plane and rotated $90^{\circ}$ counter clockwise on the dissected perforator to cover the defect. The donor site was closed primarily. The flap healed uneventfully.

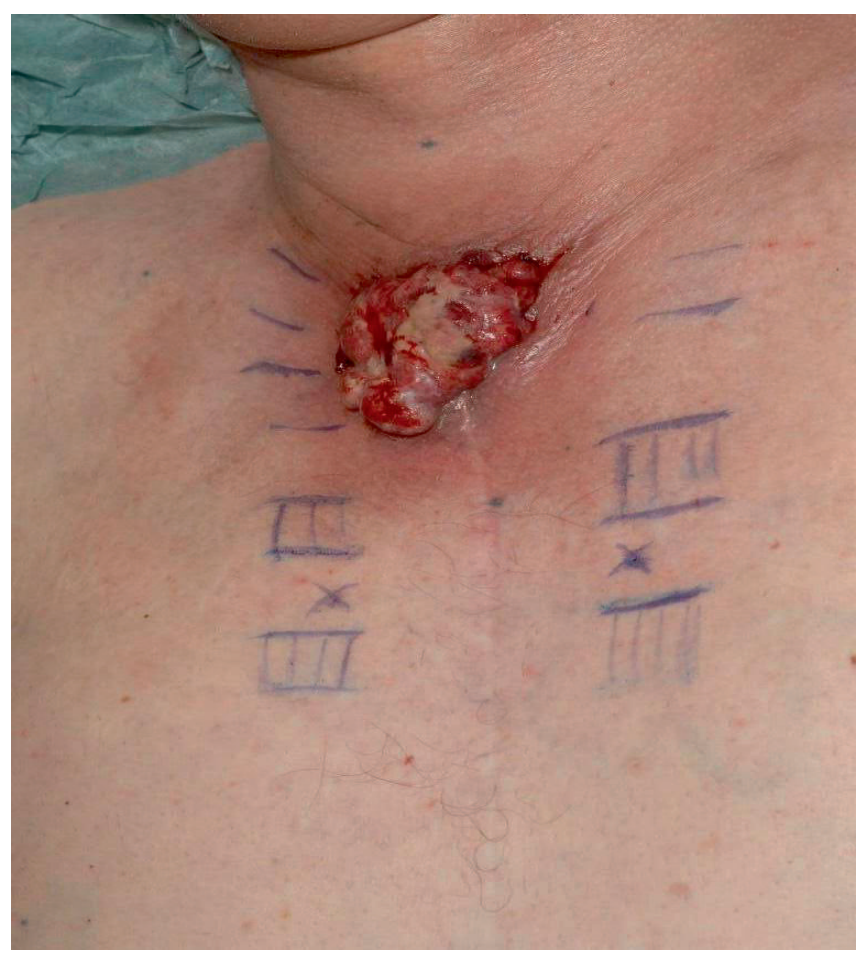




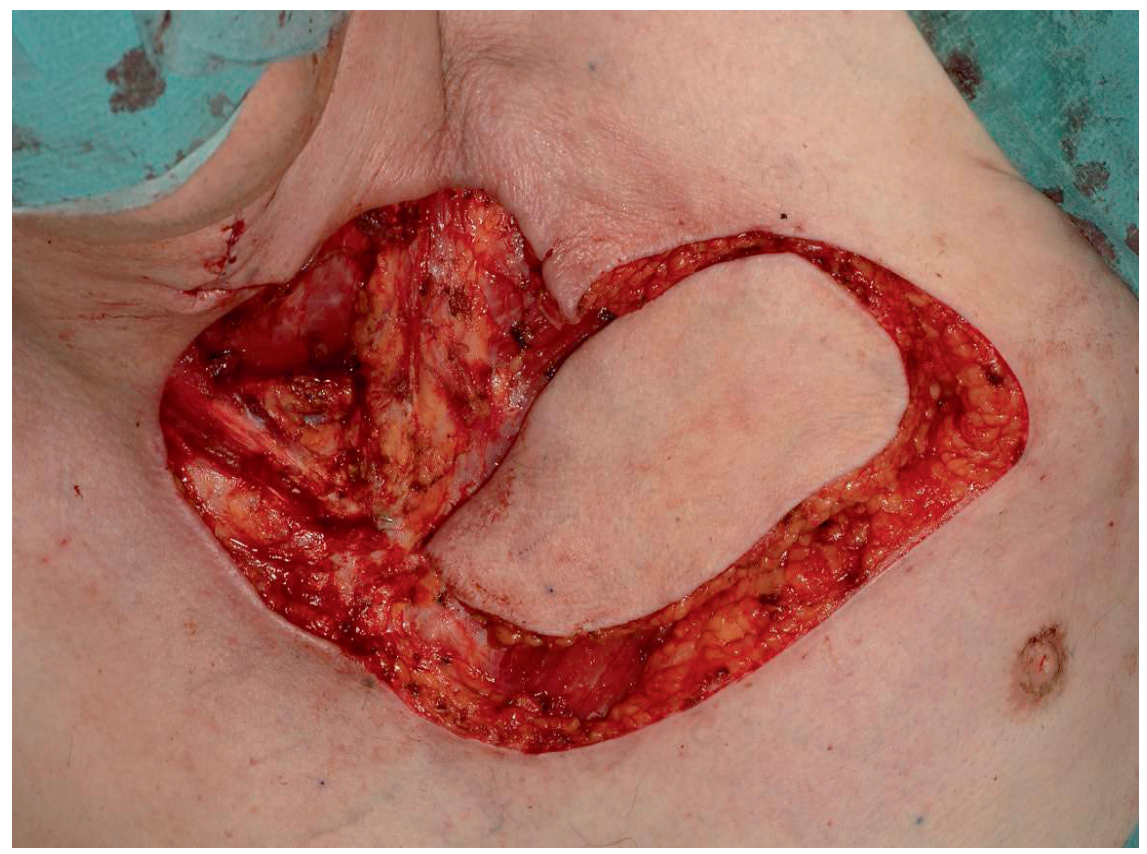

IMAP flap based on second intercostal perforator located at the medial border on the flap.

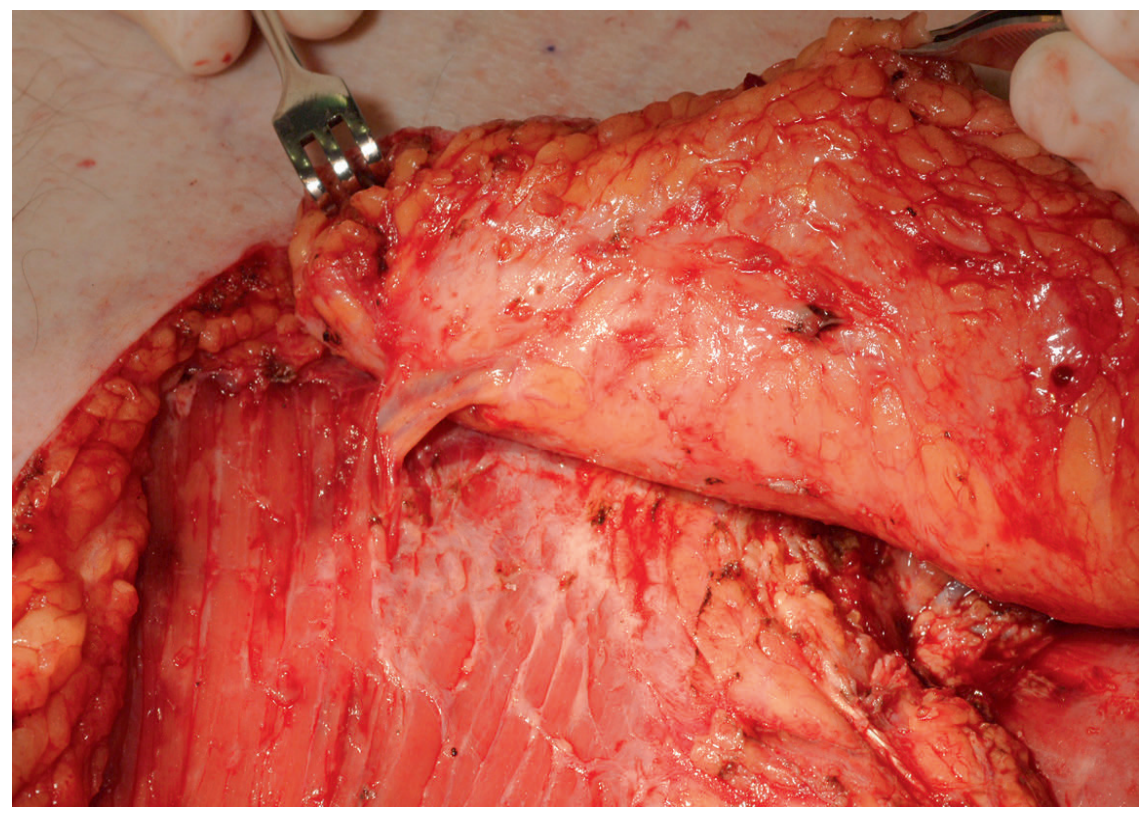

Isolated second intercostal perforator with limited intramuscular dissection. 


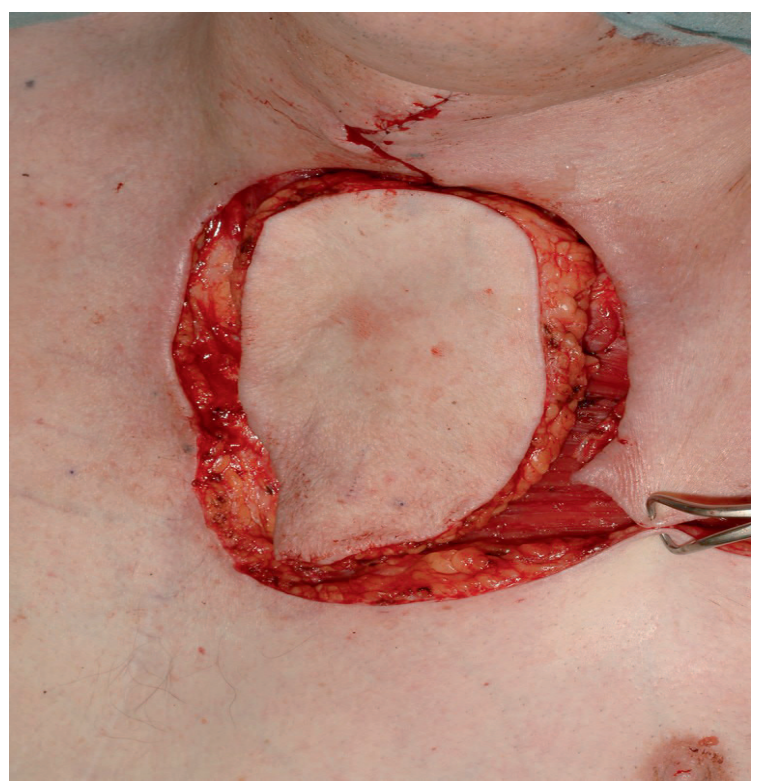

$90^{\circ}$ counter clockwise rotation of islanded IMAP flap.

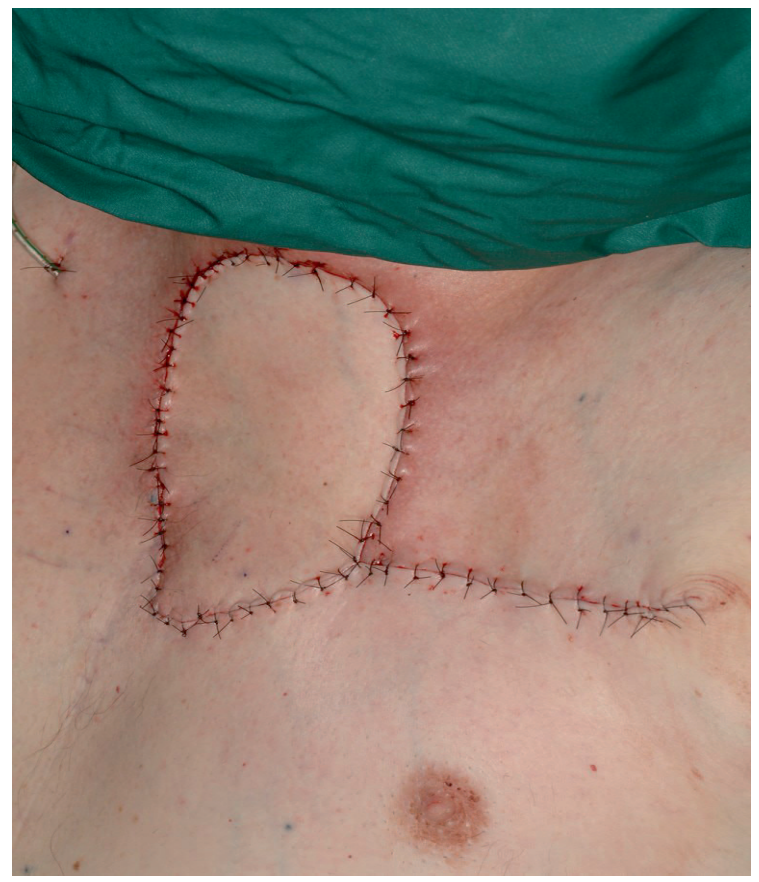

Final result with primary closure of donor site. 


\section{Case B}

A 66-year-old man with a previous irradiated supraglottic larynx squamous cell carcinoma was treated by laryngectomy and tracheostoma. Dissection of the radiated pre-tracheal flap resulted in a $5 \times 6 \mathrm{~cm}$ skin defect around the tracheostoma. An IMAP flap was planned on the right thoracic wall after Doppler identification of perforating vessels in the second and third intercostal space. Dissection was started by exploratory incision on the medial side and the second IMAP was found to be the largest. An $8 x$ $15 \mathrm{~cm}$ flap was designed in a caudal direction with the perforator at the most cranial border of the flap. To gain more pedicle length the second rib cartilage was removed together with the intercostal muscle. The internal mammary vessels were clipped distally to be able to transpose the flap cranially with the vascular pedicle lying over the first rib. Direct postoperatively the flap showed venous congestion. Re-exploration revealed compression of the vein by the accompying intercostal vein due to the rotation of the flap. After transection of the nerve the problem was solved and the flap healed uneventfully.

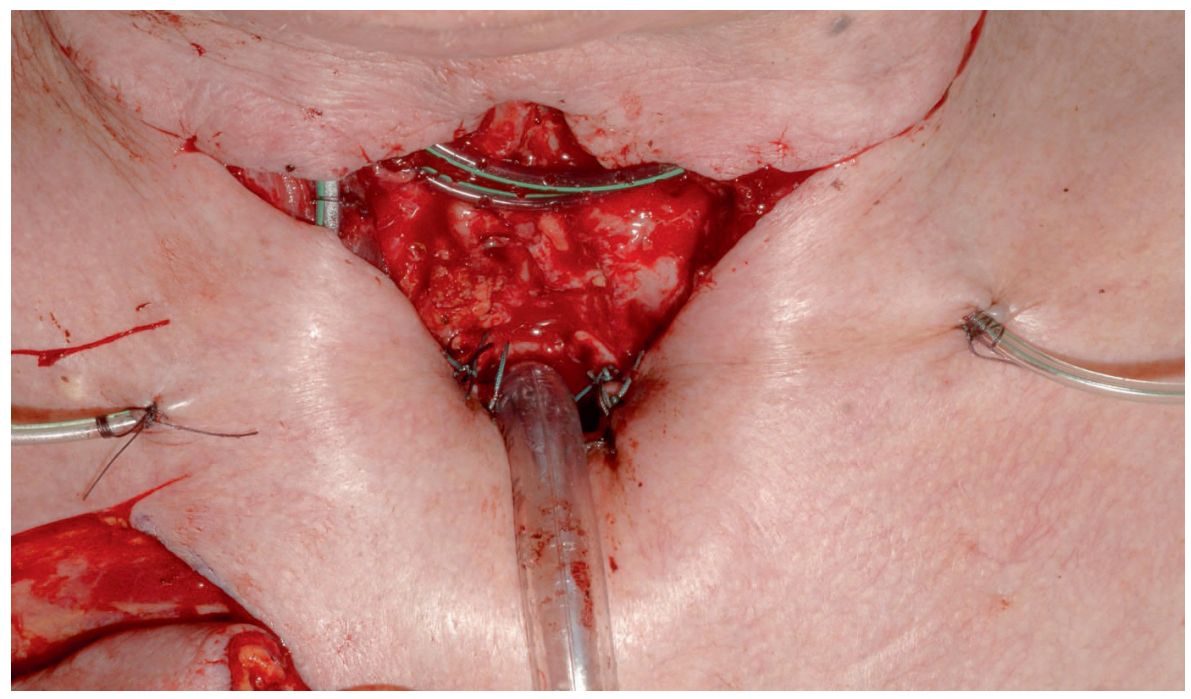




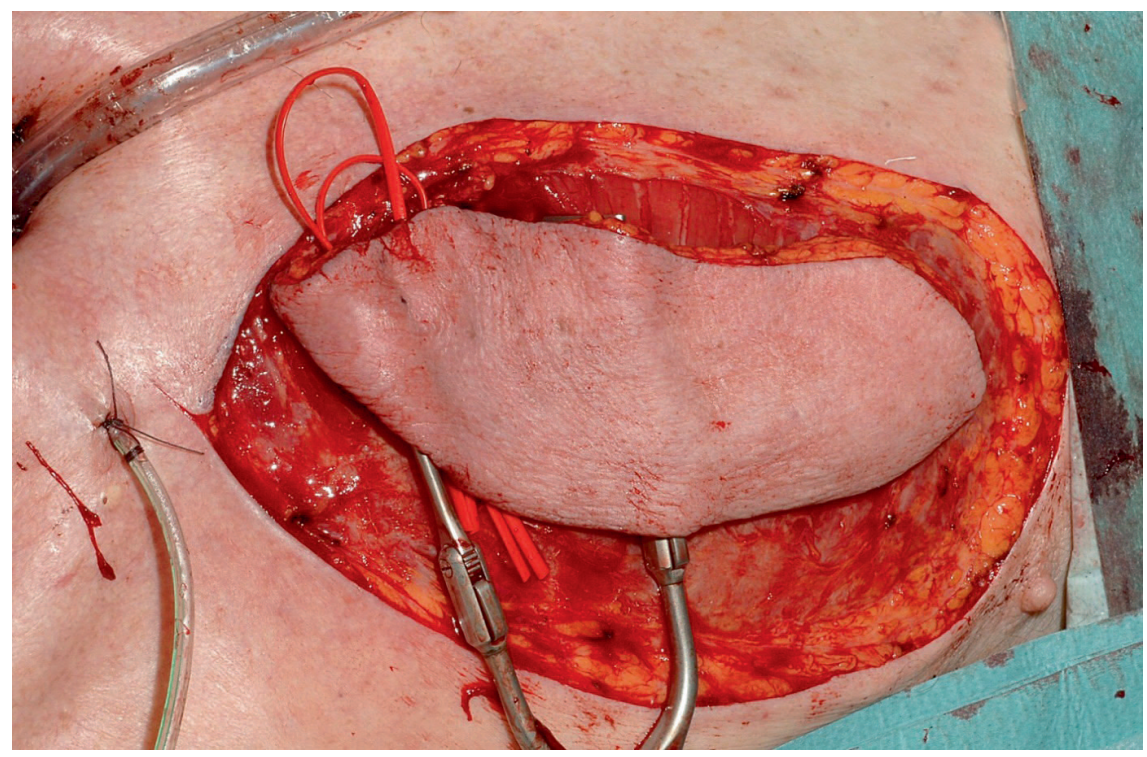

IMAP flap based on the second intercostal perforator. Perforator located at the cranial border of the flap.

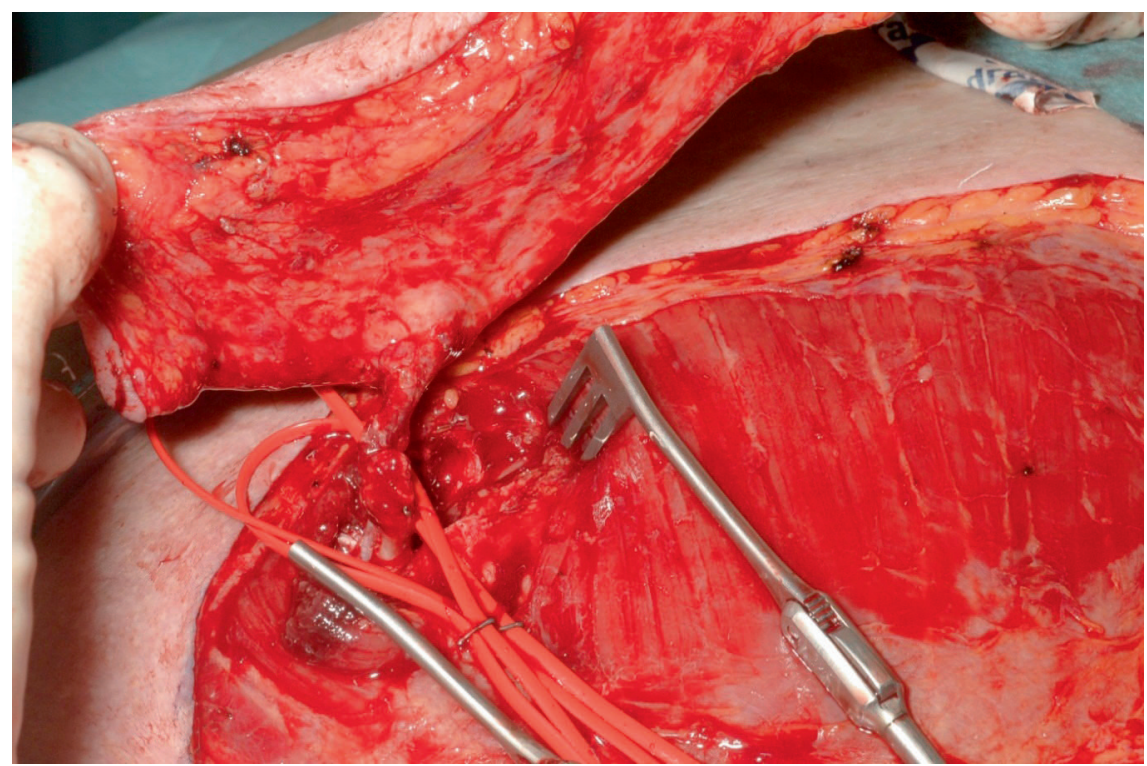

Pedicle enhancement by mobilisation of internal mammary vessels and resection of second costal rib cartilage and intercostal muscle. 


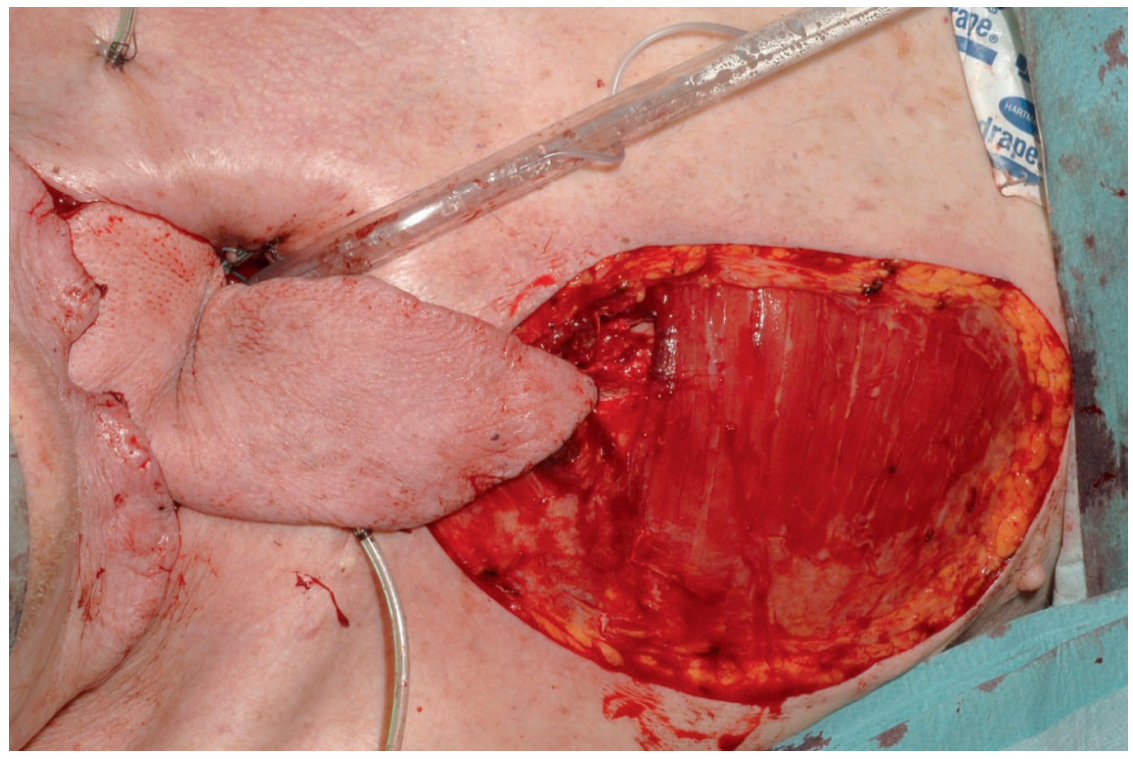

$180^{\circ}$ counter clockwise rotation-advancement of the flap.

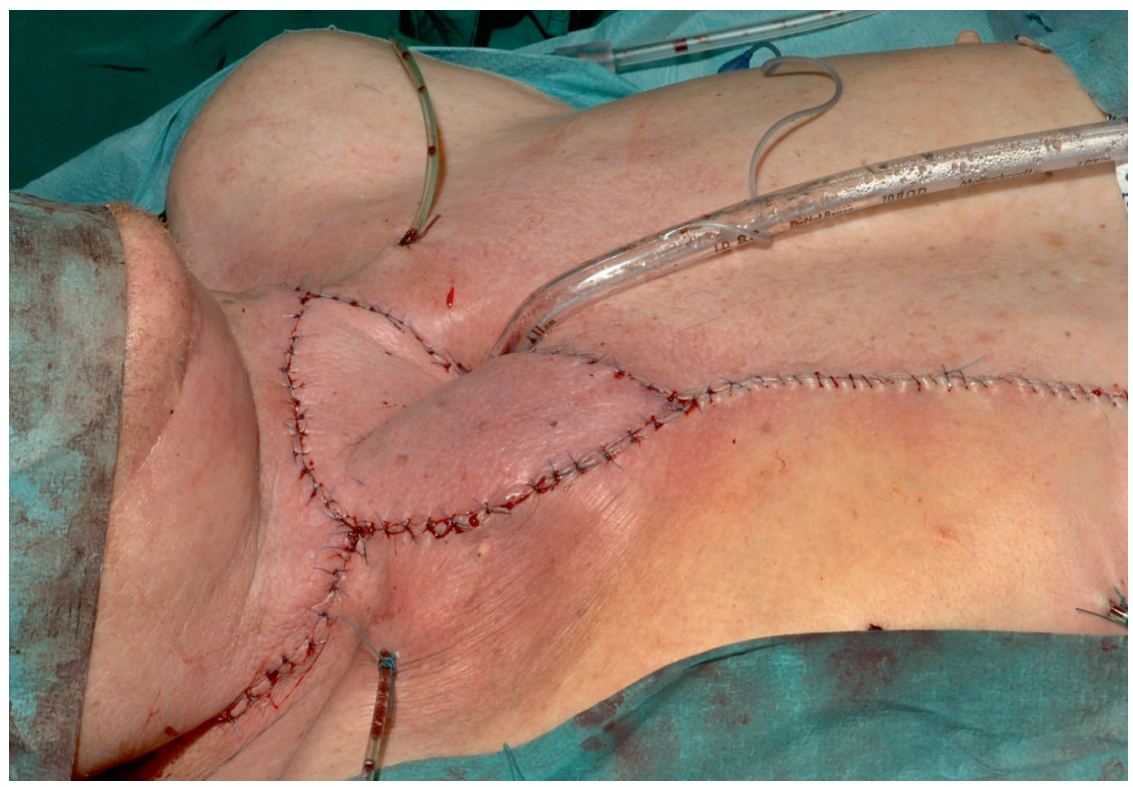

Insetting of the IMAP flap and primary closure of donor site. 


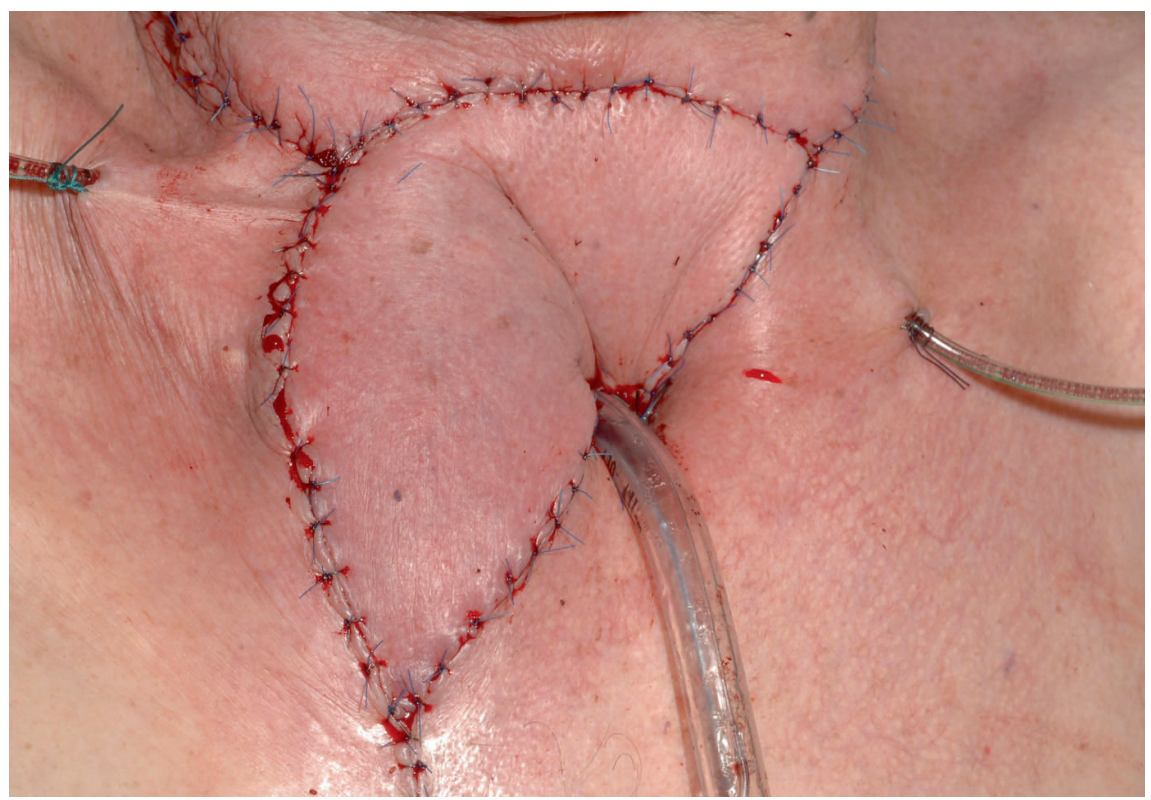

Detail of flap.

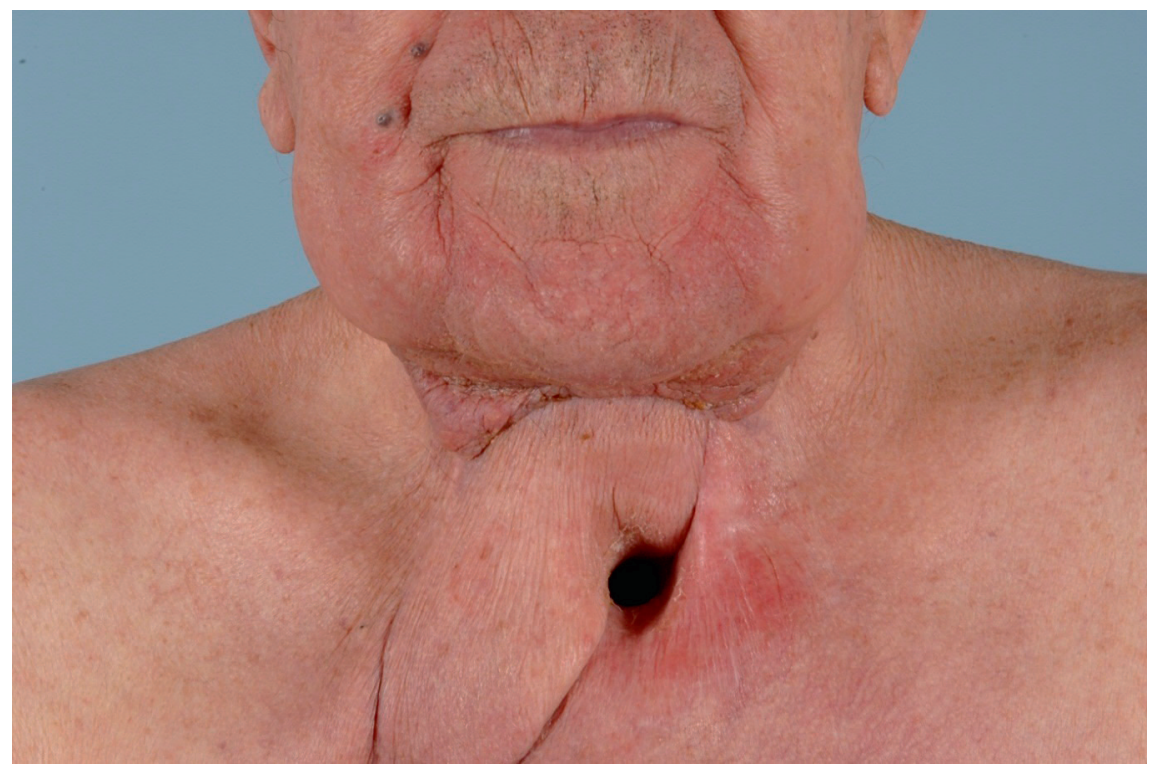

Final result with stable tracheostoma. 


\section{Case C}

A 69-year-old man presented with a large skin metastasis in the left side of the neck after earlier treatment for squamous cell carcinoma of the tongue by partial glossectomy and supra-omohyoid lymph node dissection. A modified radical neck dissection was performed including resection of the overlying skin which resulted in a $10 \times 12 \mathrm{~cm}$ defect. This was closed with a $10 \times 15 \mathrm{~cm}$ IMAP flap based on the first and third internal mammary artery perforators. Removal of the second and third rib cartilage together with the intercostal muscles was performed and distal clipping of the internal mammary vessels allowed the flap to be rotated $180^{\circ}$ counter clockwise into the defect. The cranial part of the flap was deepithelialized and placed under the skin bridge between the defect and the cranial border of the donor site. Slight venous congestion occurred within the first 24 hours but disappeared without any treatment. The donor site was closed primarily.

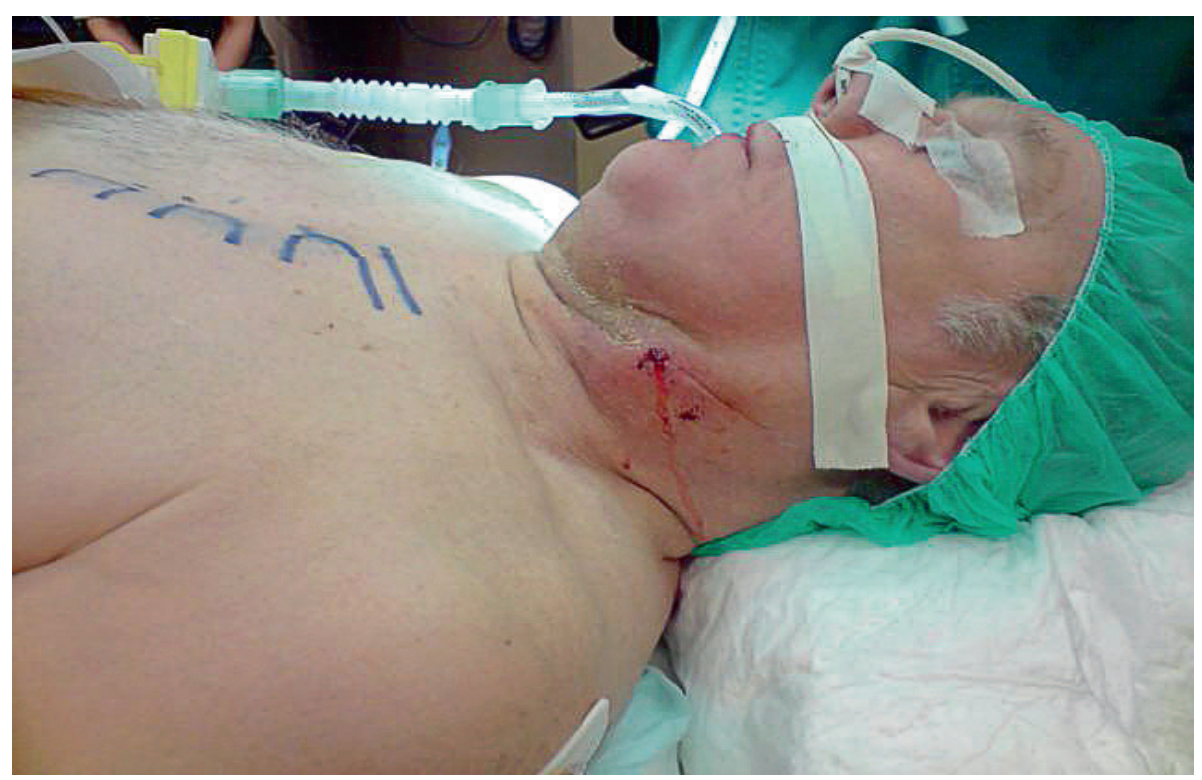




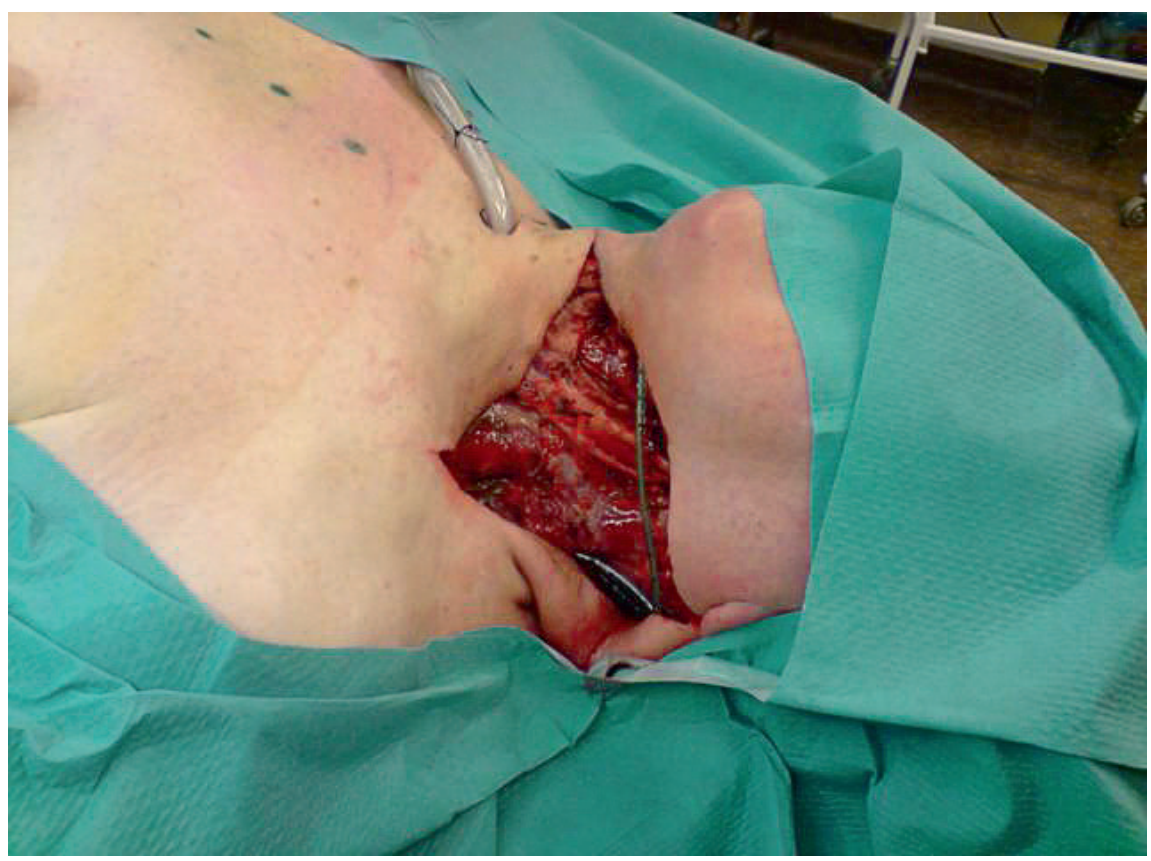

Defect after modified radical lymph node dissection including overlying skin.

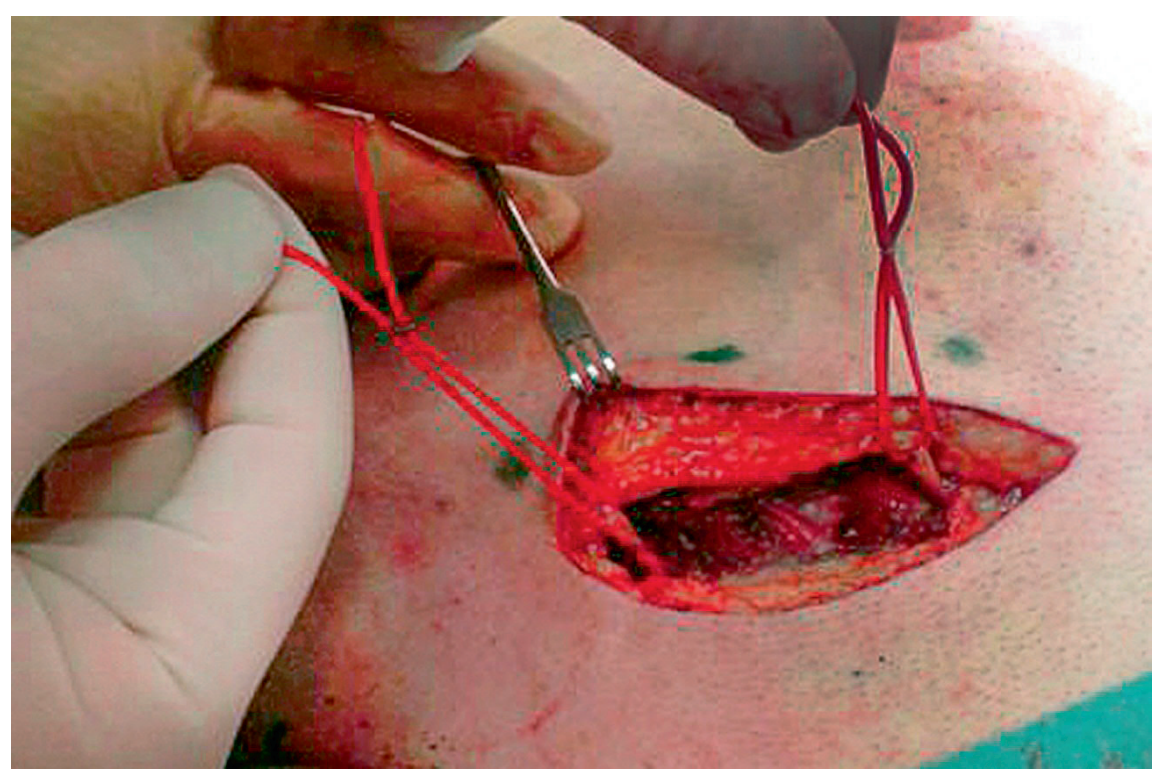

Exploratory medial incision exposing first and third intercostal perforator. 


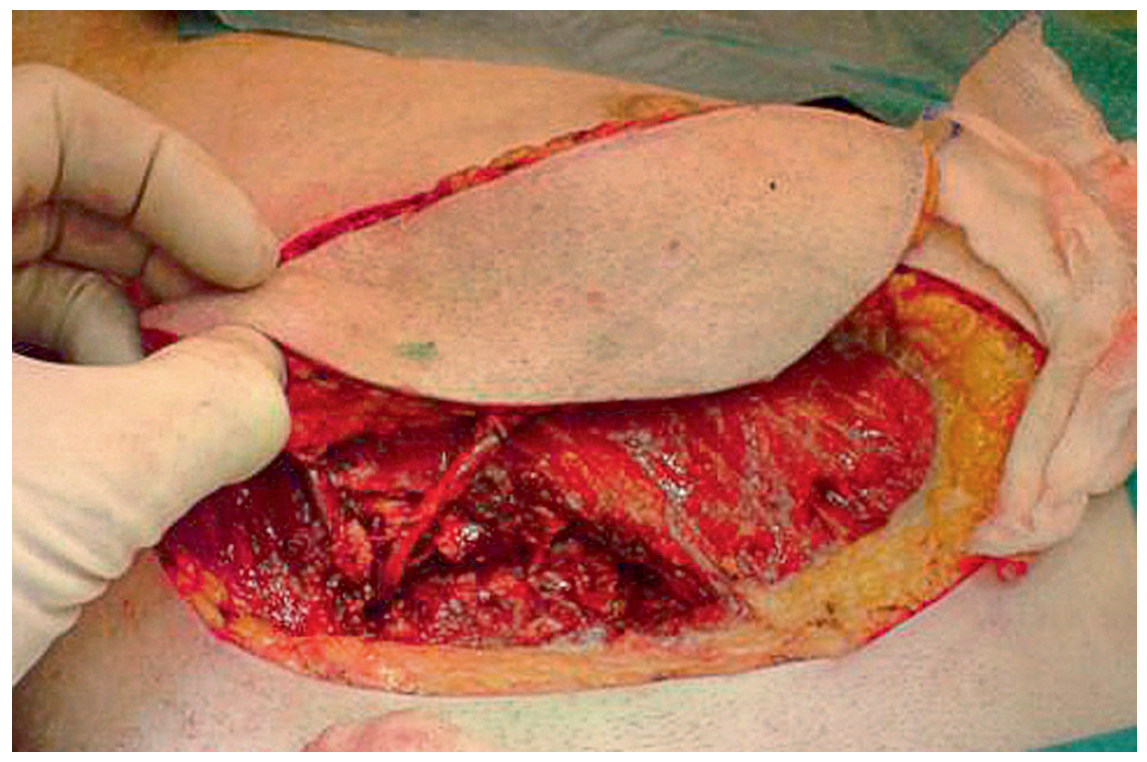

Craniocaudal based IMAP flap on first and third intercostal perforator.

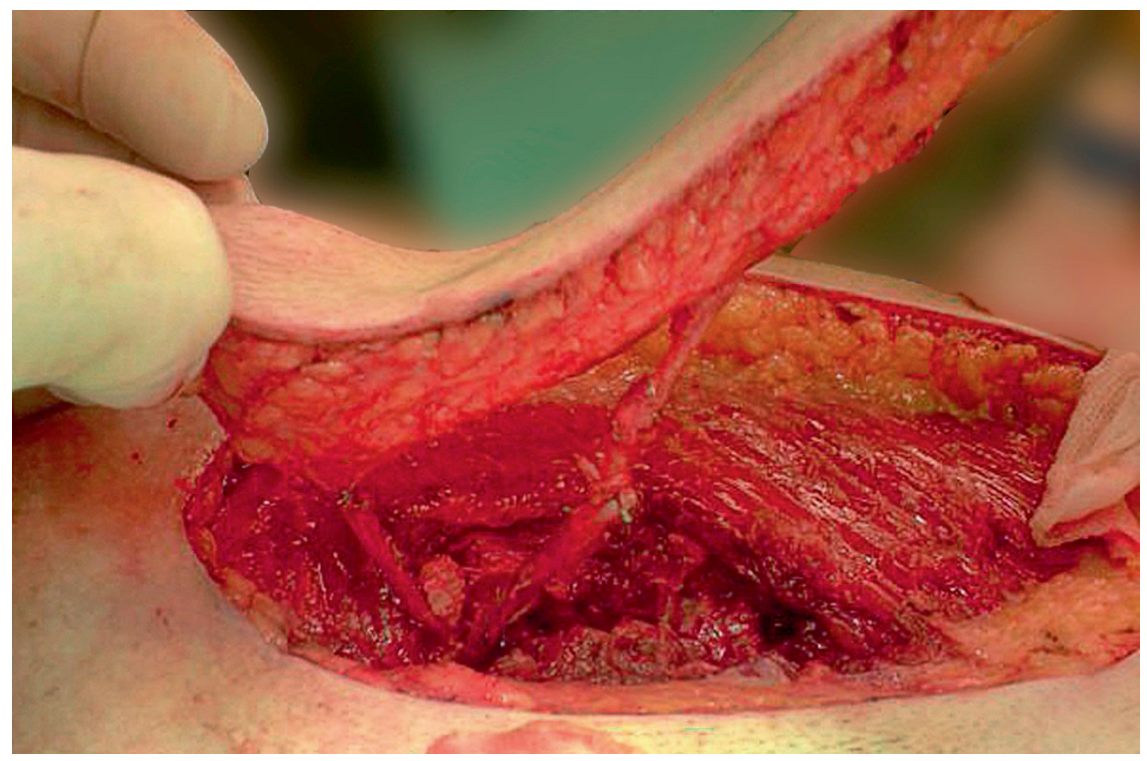

Detail of perforators. 


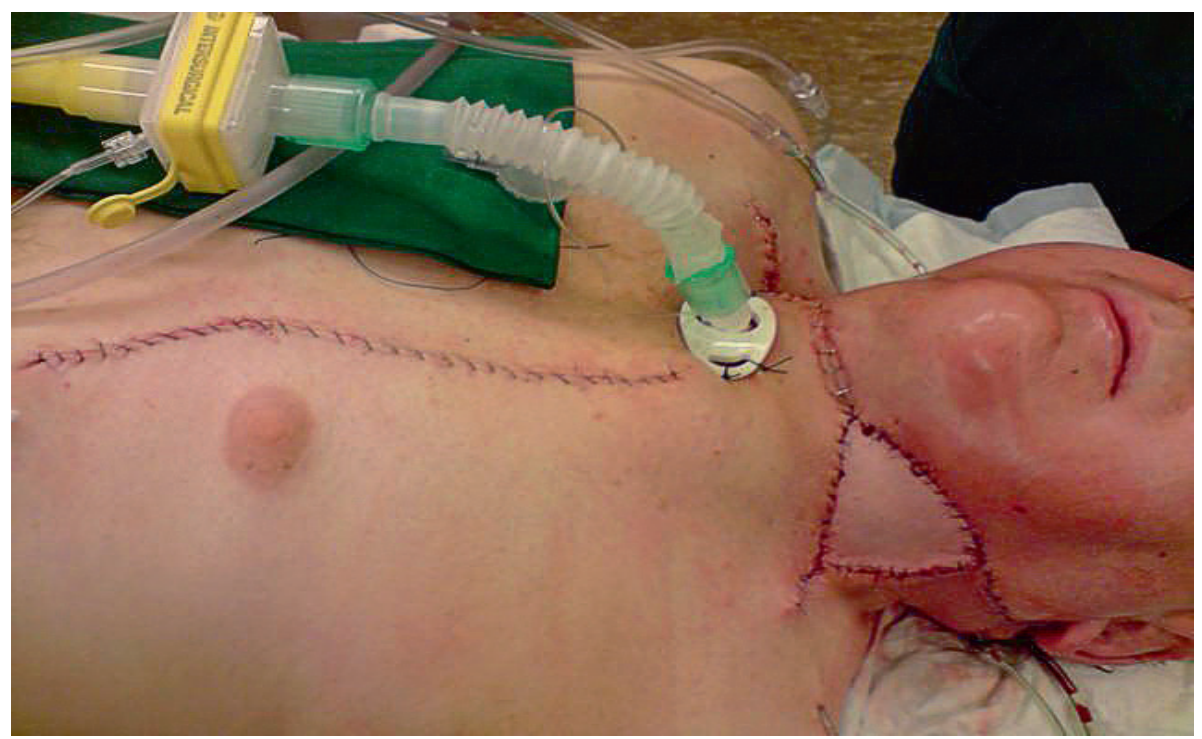

Insetting of flap after $180^{\circ}$ counter clockwise rotation and tunneling under supraclavicular skin. Primary closure of donor site.

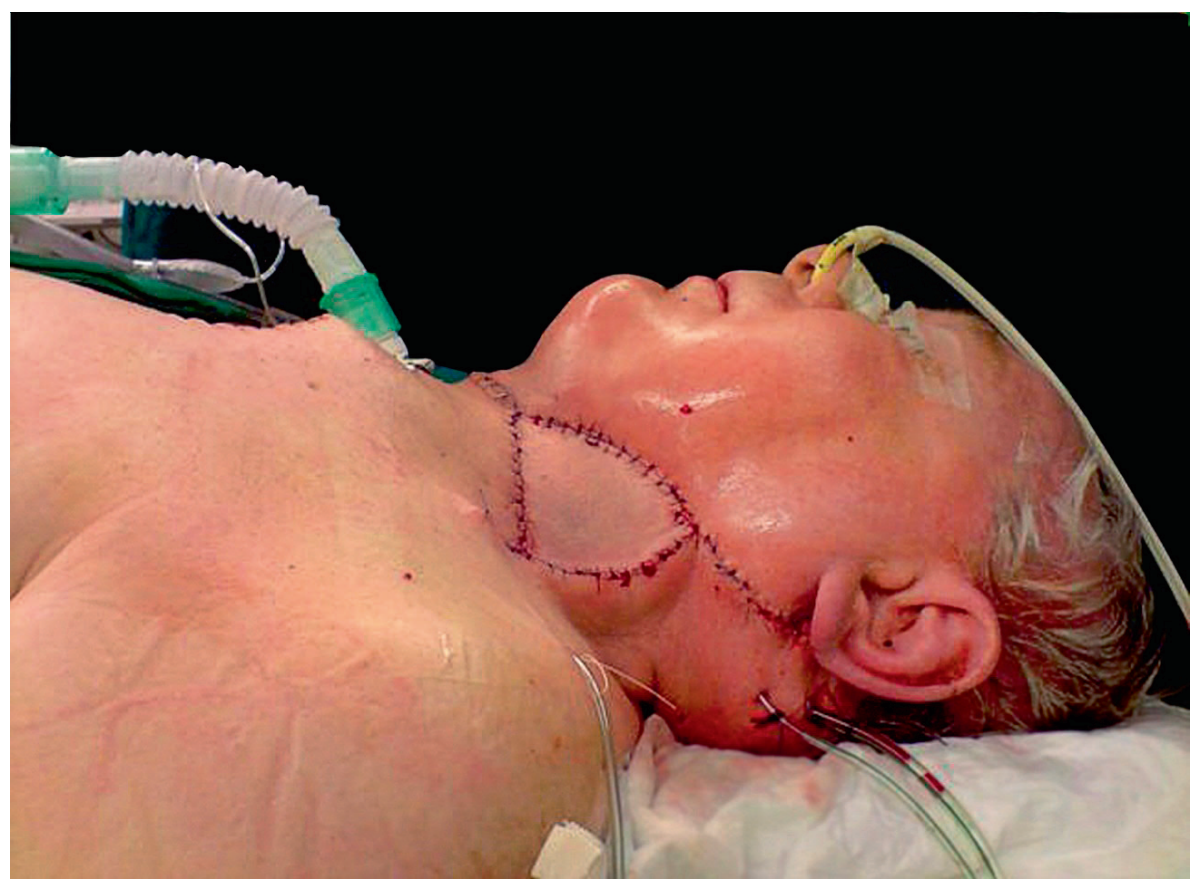

Lateral view. Part of the defect was closed primarily. 


\section{Case D}

A 63-year-old man presented with a cutaneous metastasis of a hypopharyngeal T2 squamous cell carcinoma. An unilateral lymph node dissection was performed including the overlying skin of the left side of the neck which resulted in an $8 \times 12$ $\mathrm{cm}$ defect. A $9 \times 14 \mathrm{~cm}$ IMAP flap was created in an inferior-lateral direction based on the second and fourth mammary artery perforators. Enhancement of the vascular pedicle was performed by resection of the second and third rib cartilage including the intercostal muscles together with distal clipping of the internal mammary vessels. This allowed the flap to be rotated counter clockwise into the defect. A small proximal part of the flap was deepithelialized and buried under the supraclavicular skin. The donor site was closed primarily. The flap healed uneventfully and the patient was irradiated without any wound problems.

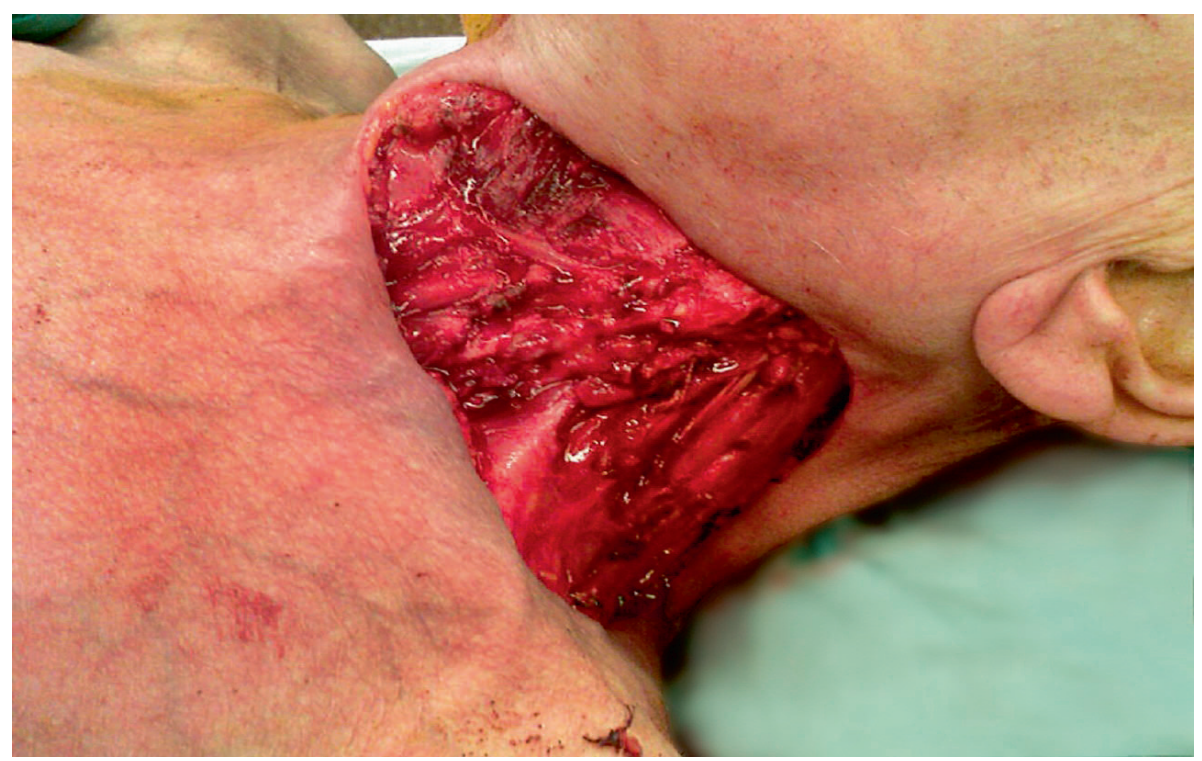




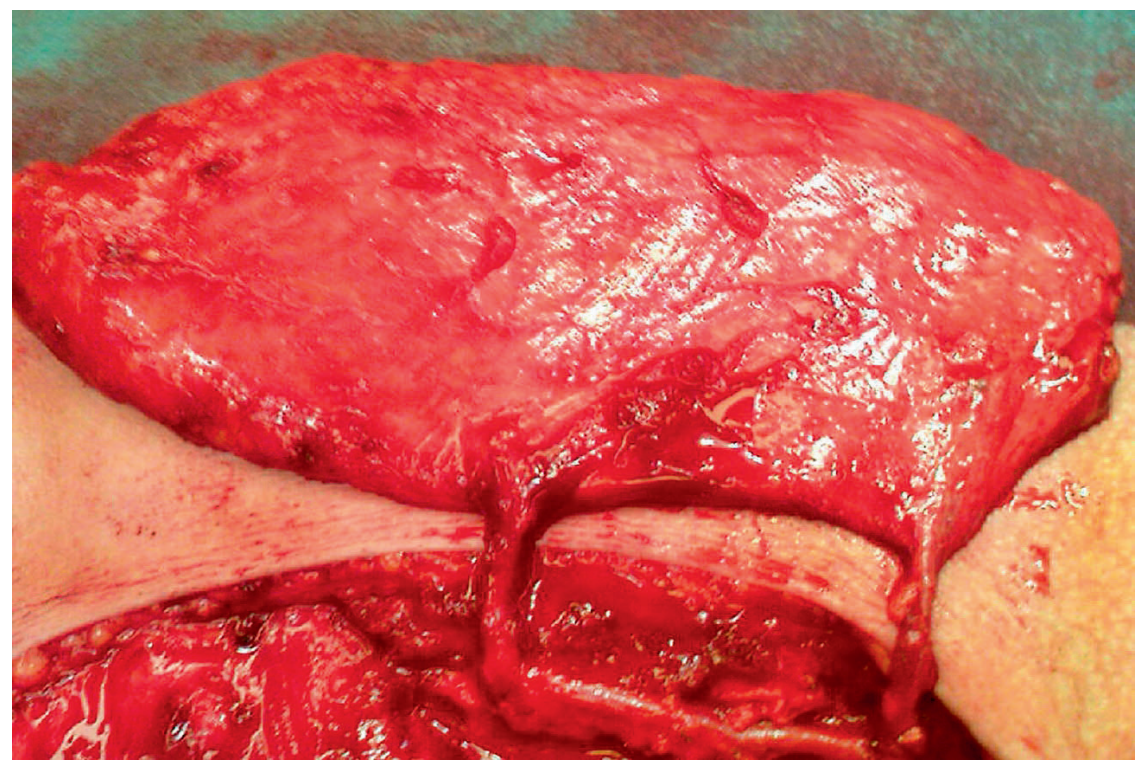

IMAP flap on second and fourth mammary artery perforator.

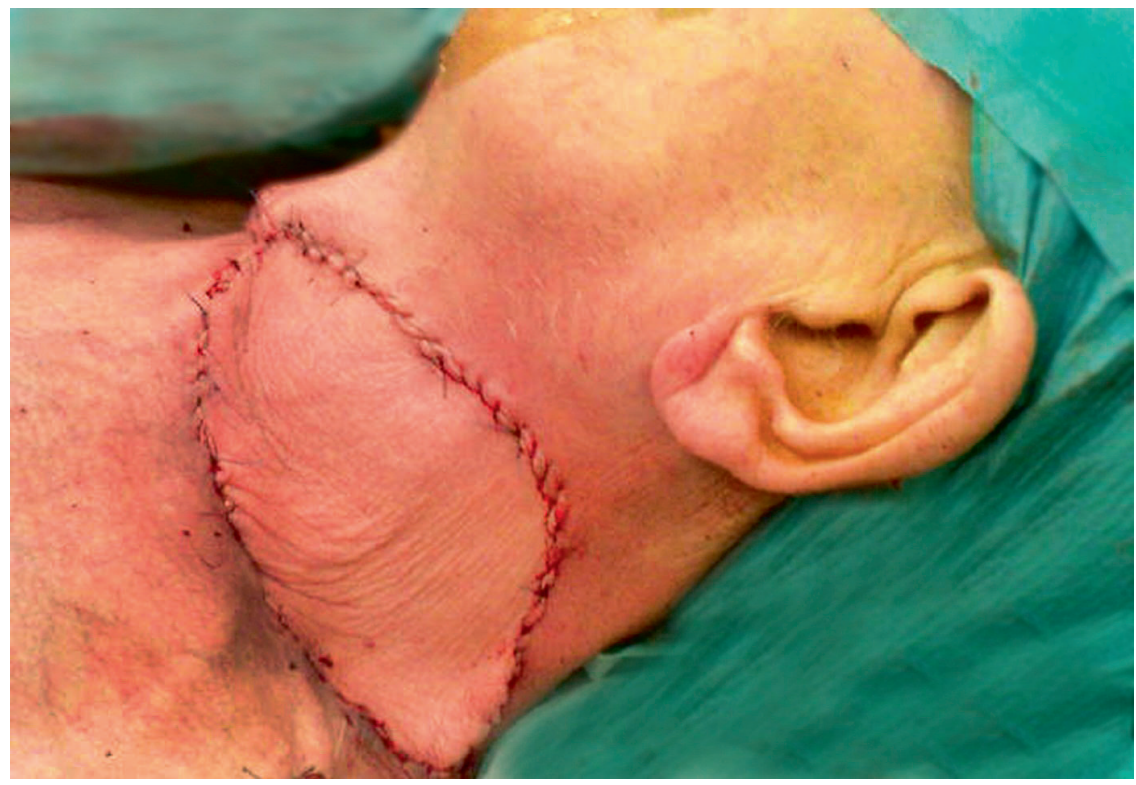

Insetting of the flap. Flap has been rotated $180^{\circ}$ counter clockwise.

Small cranial part of the flap is buried under the supraclavicular skin. 


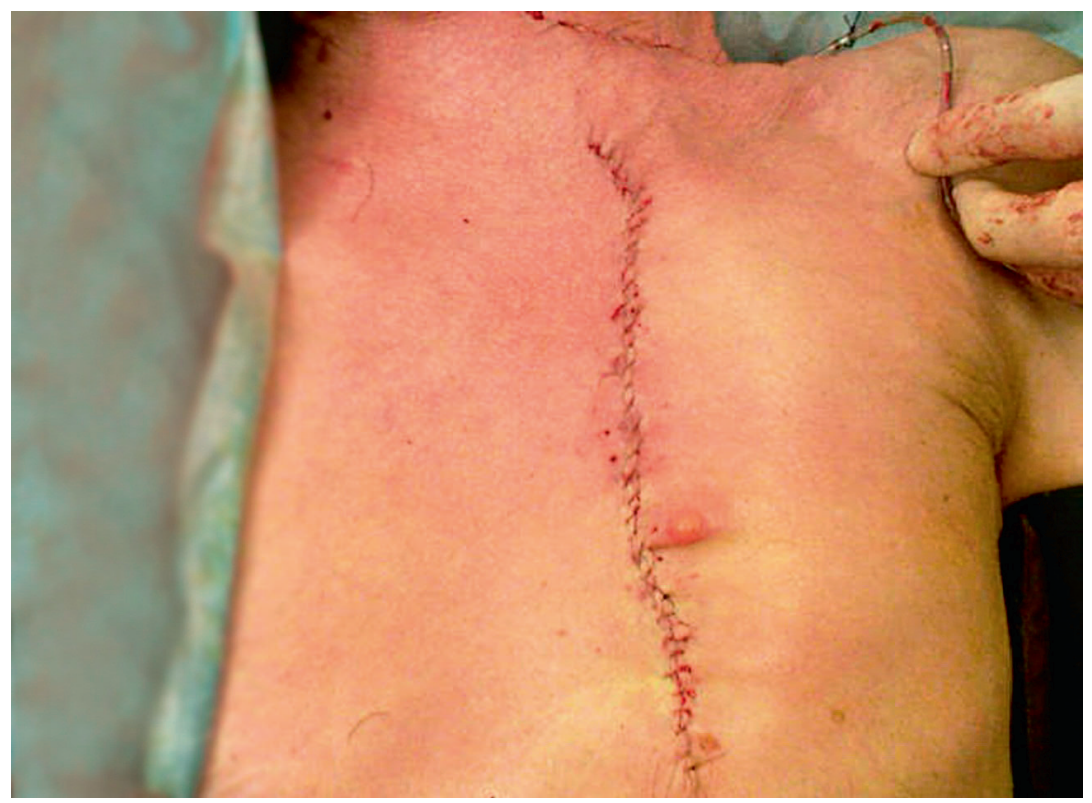

Primary closure of donor site.

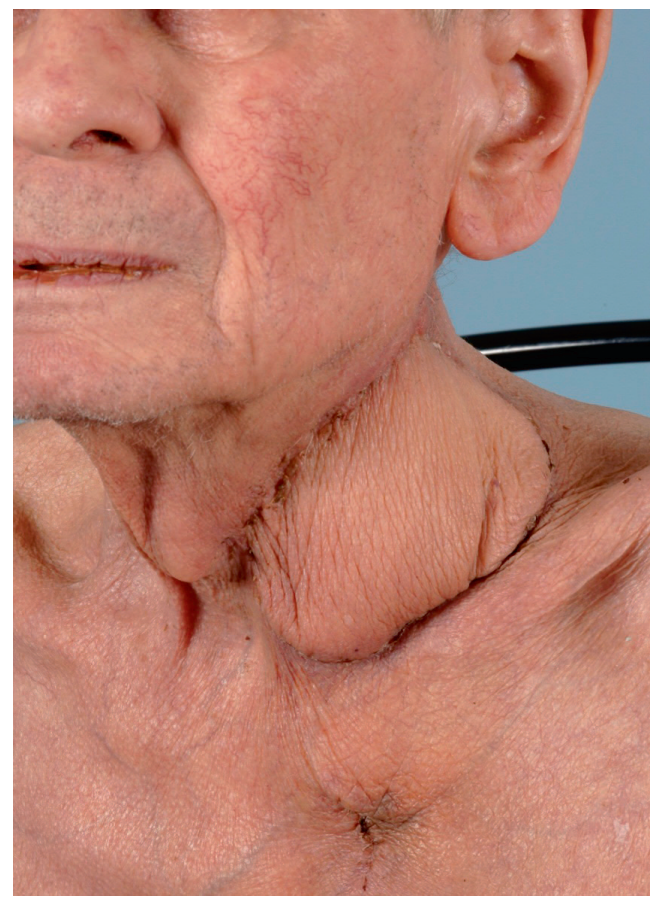

Early postoperative result. 


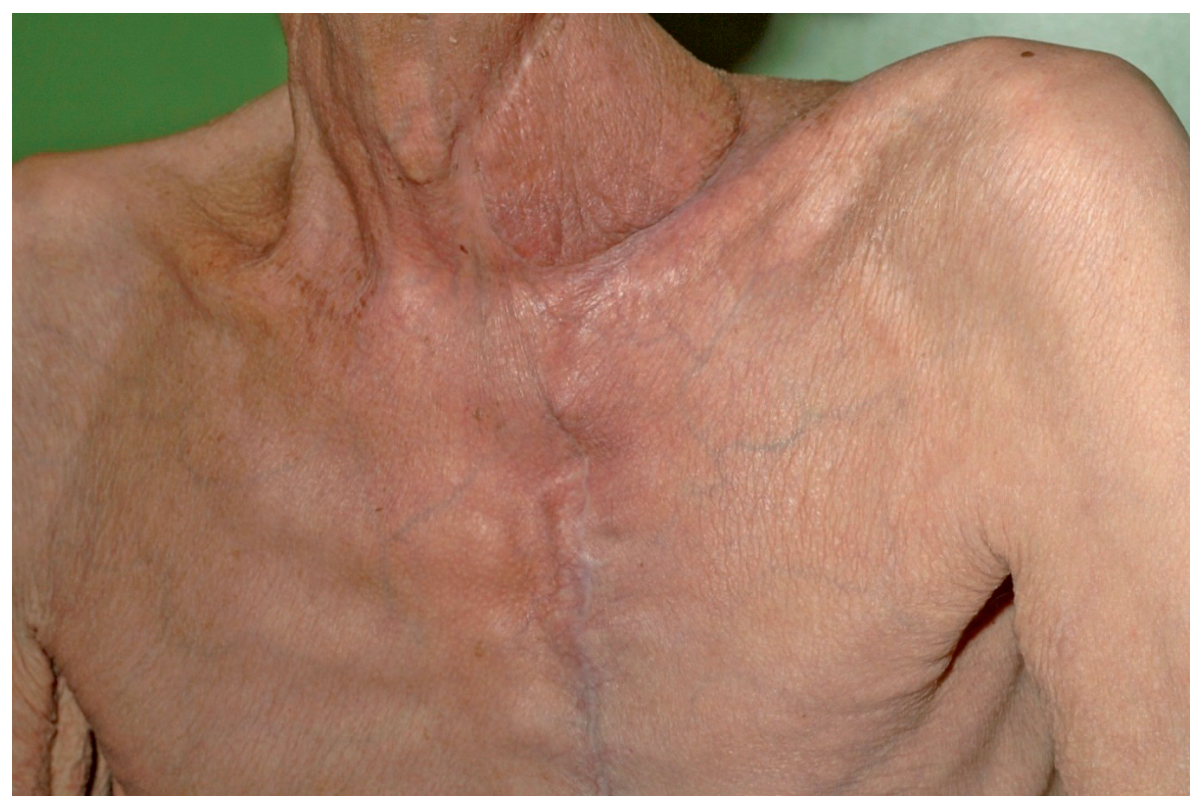

Stable reconstruction after radiotherapy.

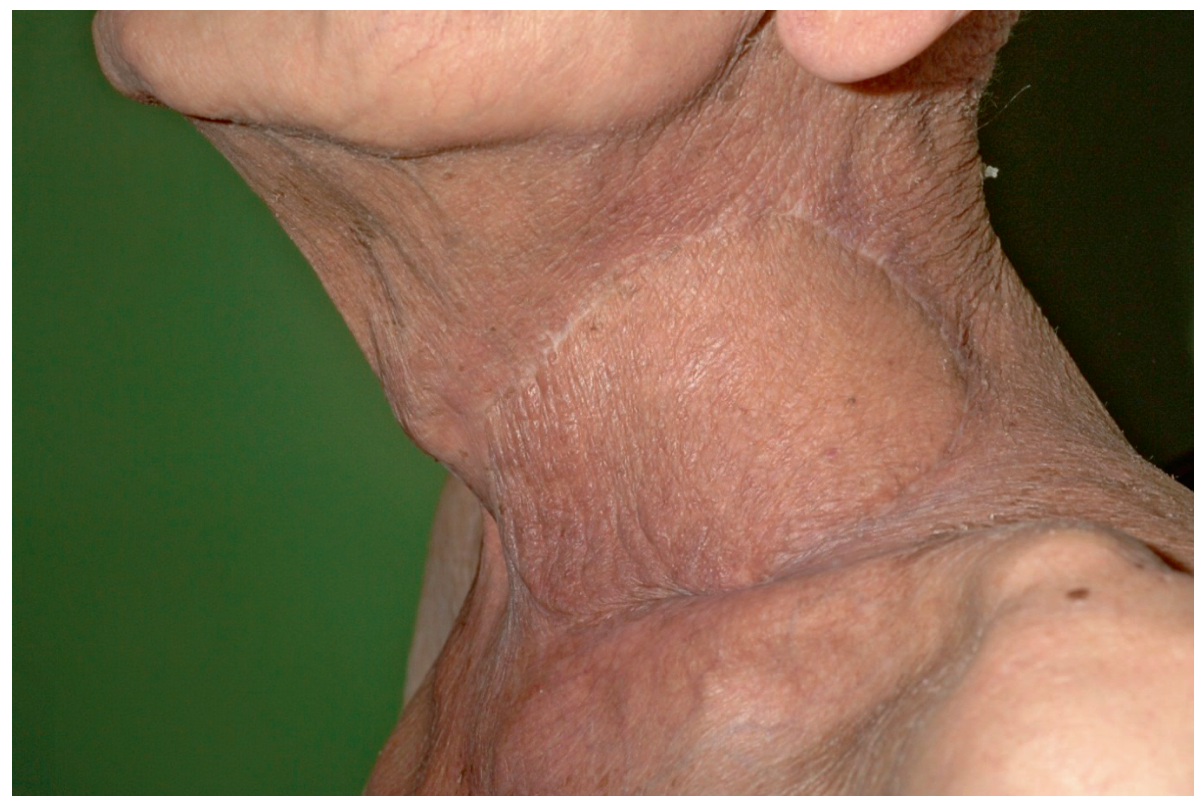

Lateral view. 


\section{Case E}

A 62-year-old man presented with a large metastasis of a T2N3 hypopharynxcarcinoma. Previous treatment consisted of chemo-radiation therapy. A palliative lymph node dissection was performed with inclusion of the overlying skin of the left side of the neck which resulted in a $10 \times 13 \mathrm{~cm}$ defect with exposure of the radiated carotid artery and internal jugular vein. A $10 \times 16 \mathrm{~cm}$ IMAP flap was designed in a caudal direction and based on the second and third intercostal perforating vessels. Pedicle enhancement was performed by removal of second and third rib cartilage including the intercostal muscles. Distal clipping of the internal mammary vessels allowed the flap to be transposed into the defect. The proximal part of the flap was deepithelialized and buried under the supraclavicular skin. The donor site was closed primarily and the flap healed uneventfully.

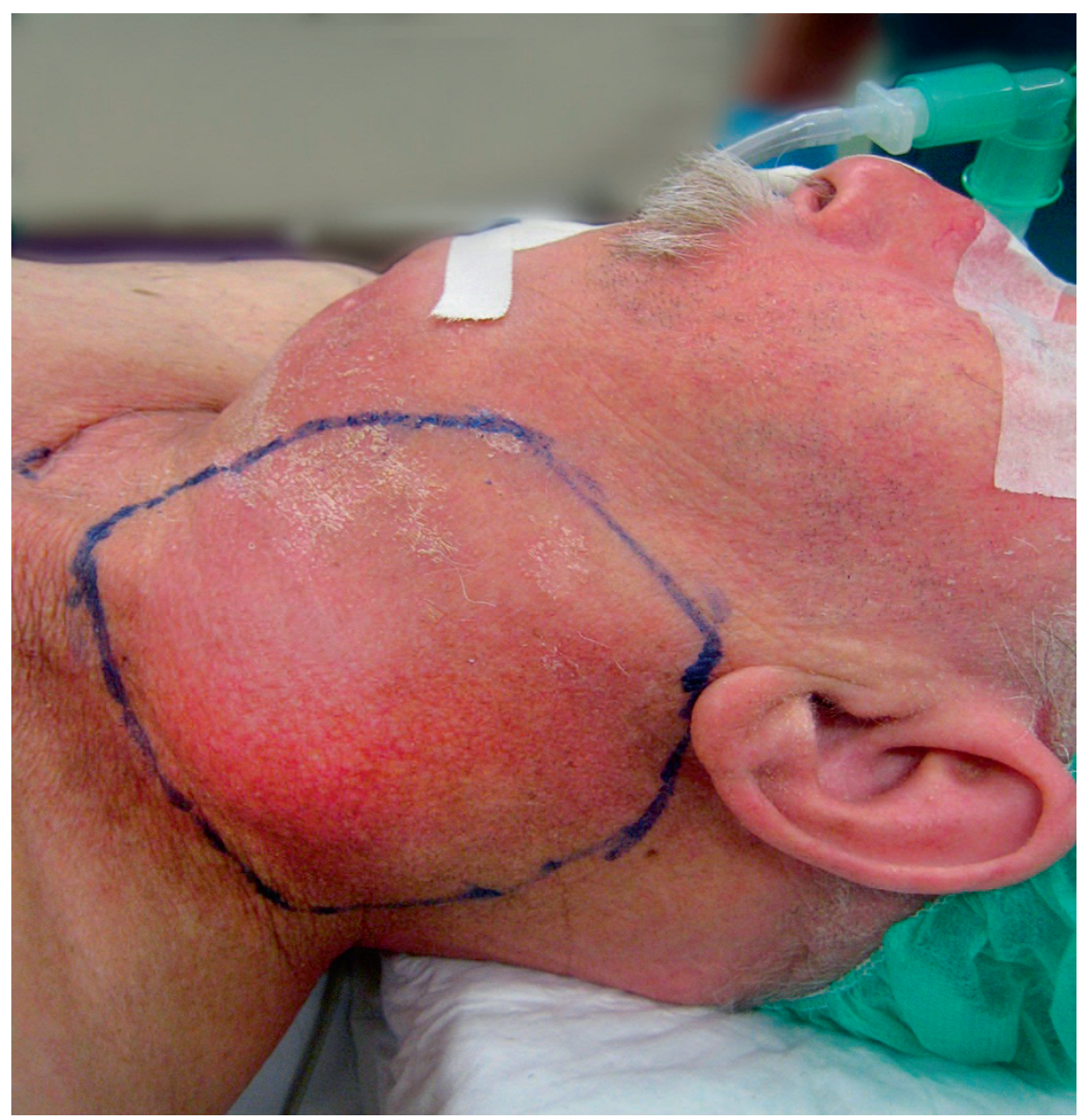




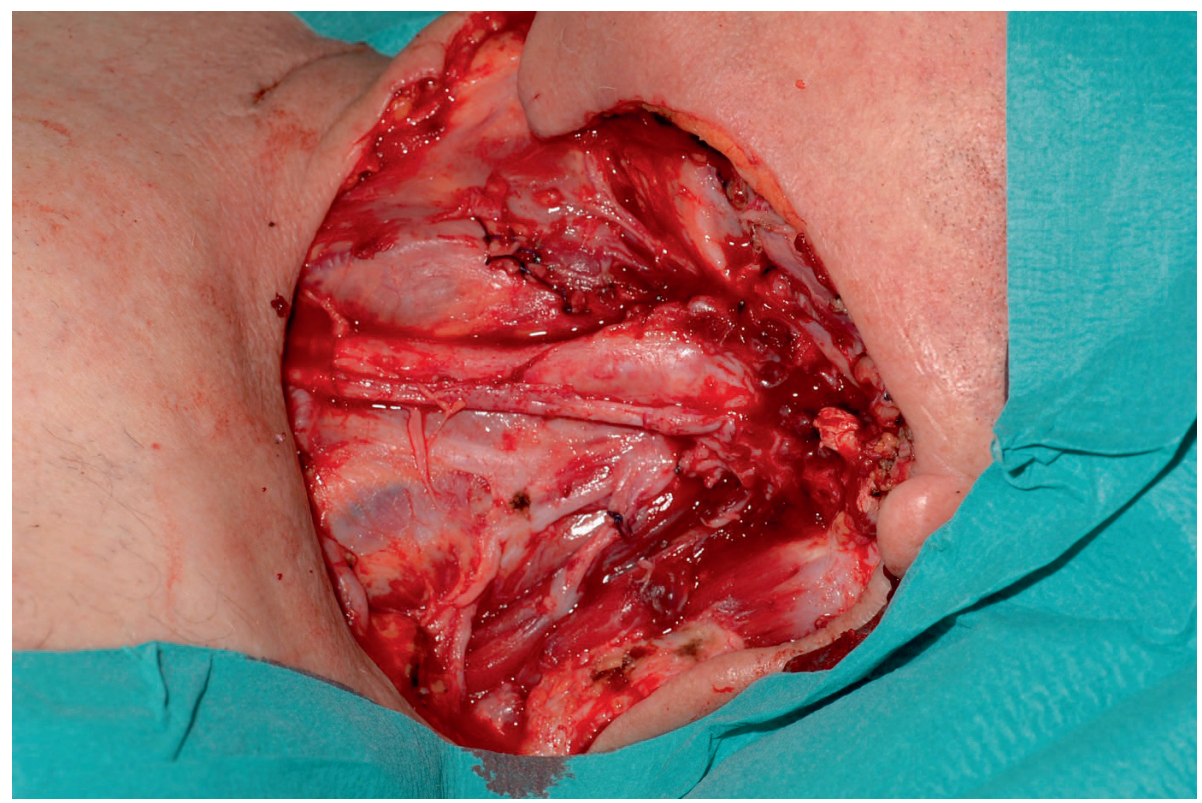

Defect with exposure of the radiated carotid artery and internal jugular vein.

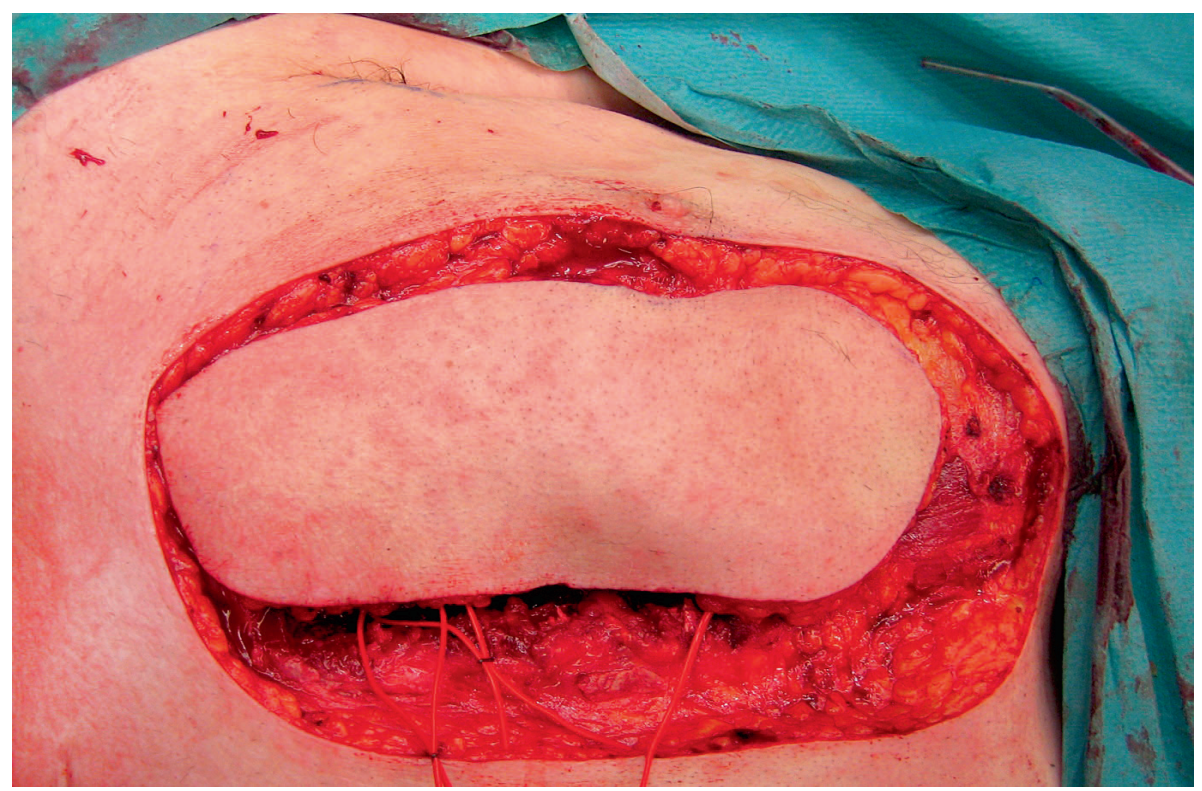

Craniocaudal based IMAP flap on left thorax. 


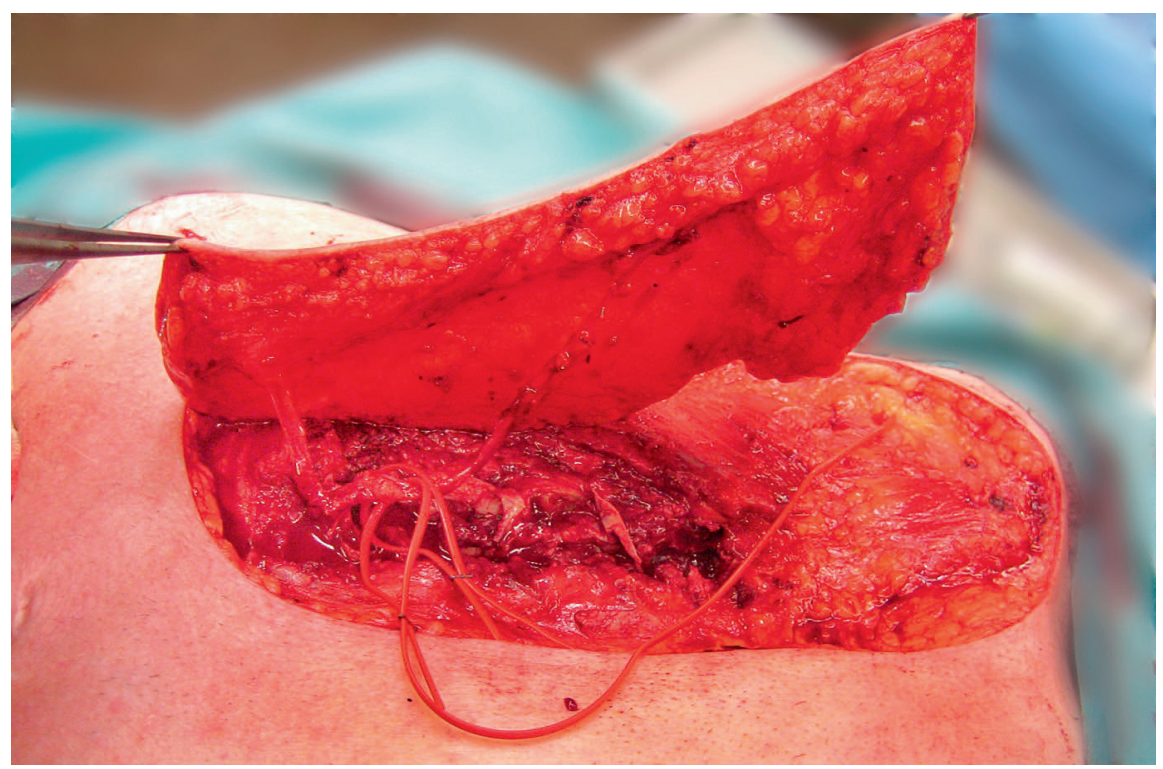

Pedicle enhancement by distal clipping of internal mammary vessels and resection of second and third rib cartilage. (note that this photo was taken from the right side of the patient, locating his neck at the left side of the photo).

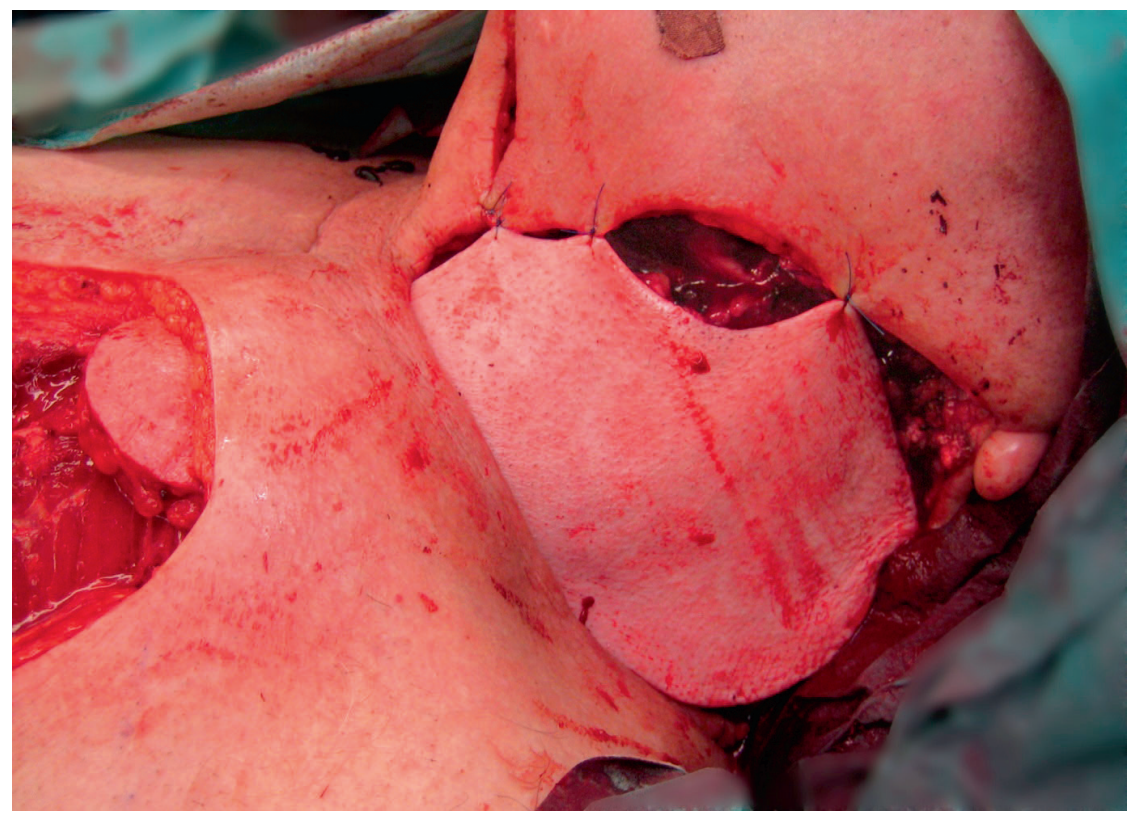

Temporary fixation of the flap, tunneling under supraclavicular skin bridge. 
Pedicled IMAP island flap for lower head and neck reconstructions

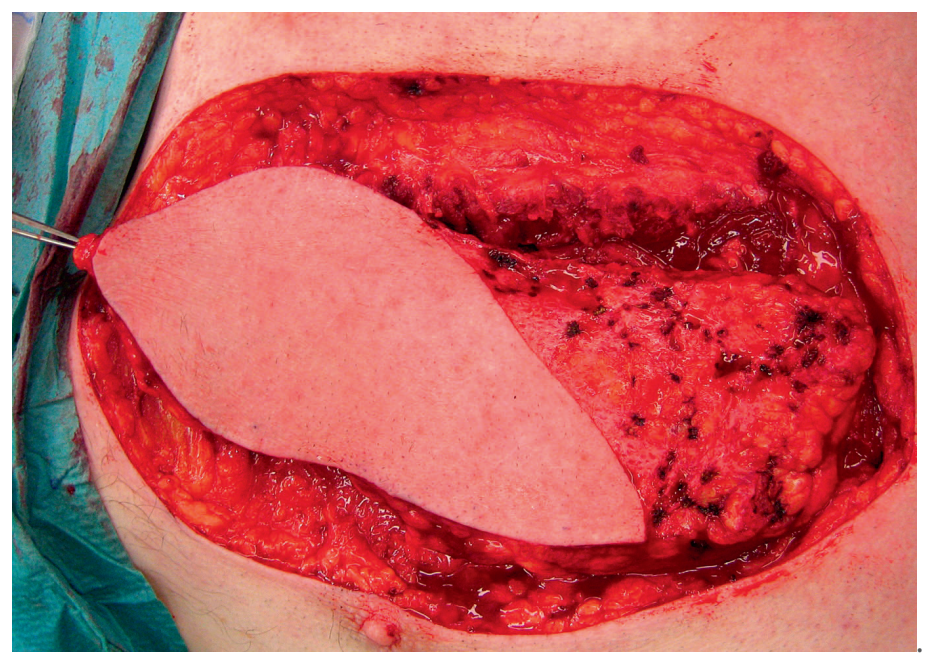

Deepithelialization of cranial part of the flap.

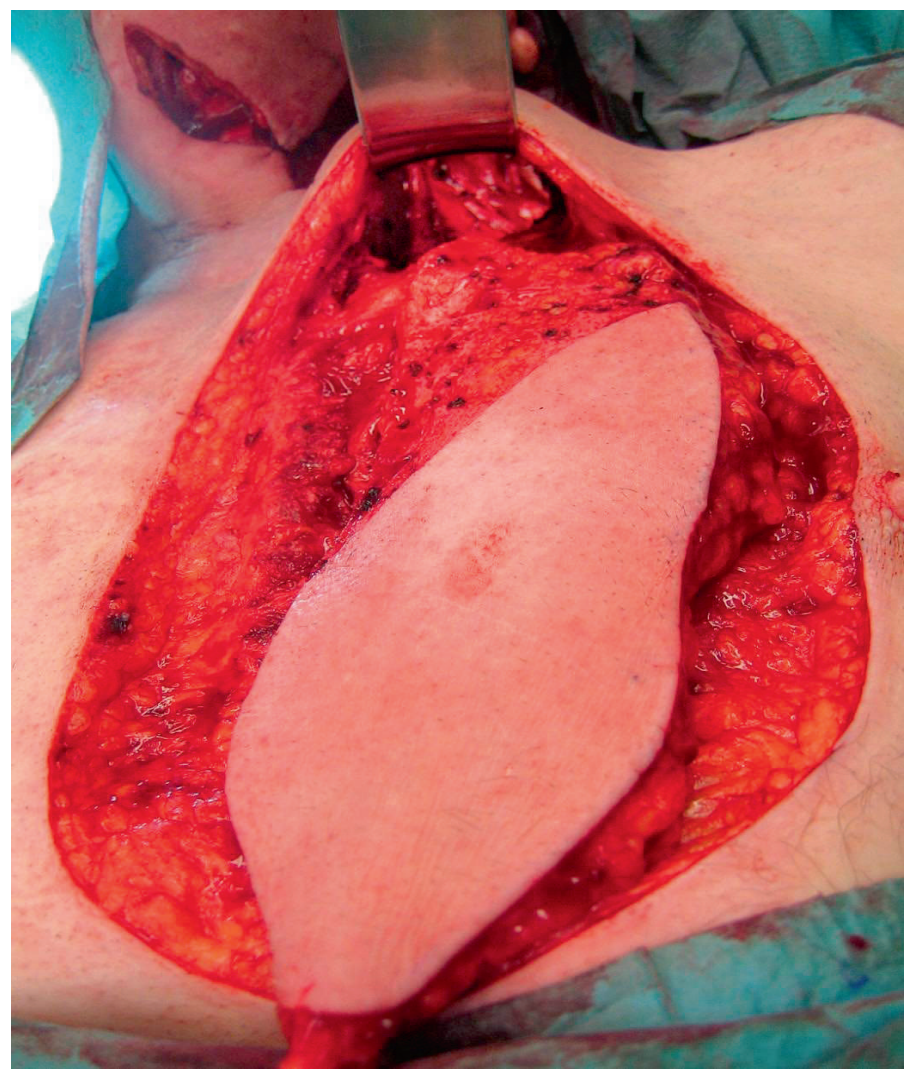

Counter clockwise rotation and tunneling of the flap. 


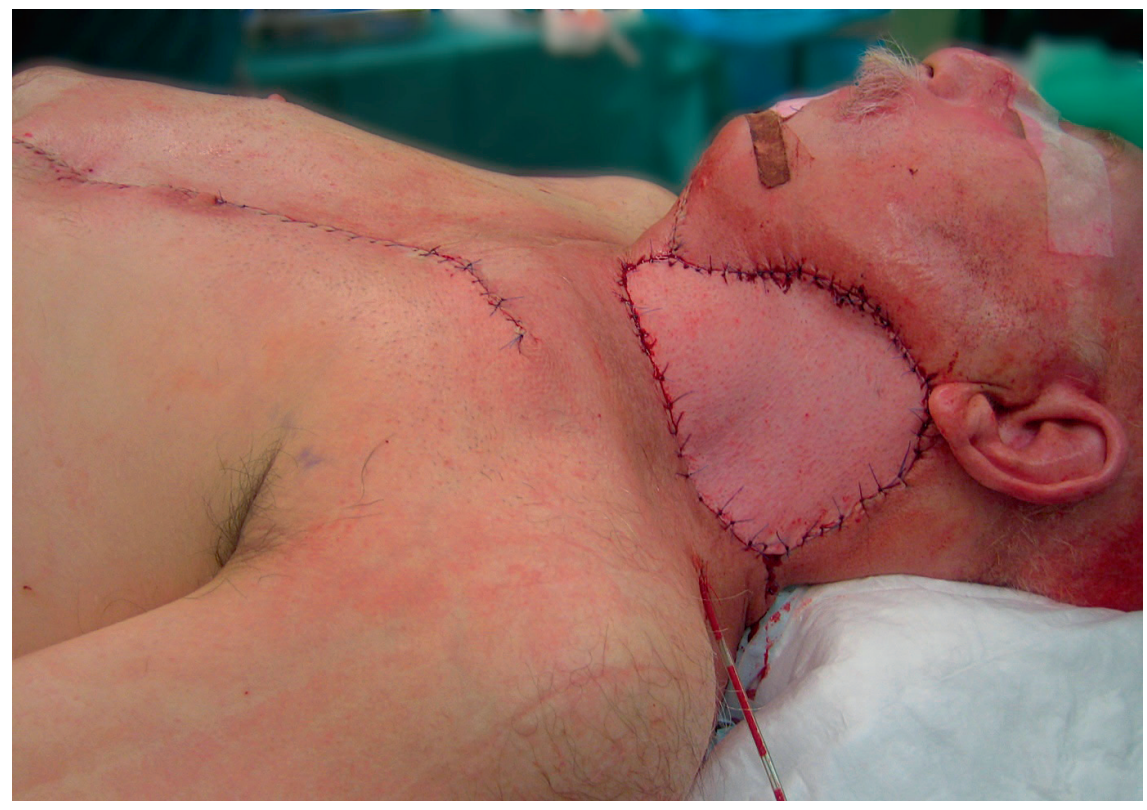

Insetting of the flap.

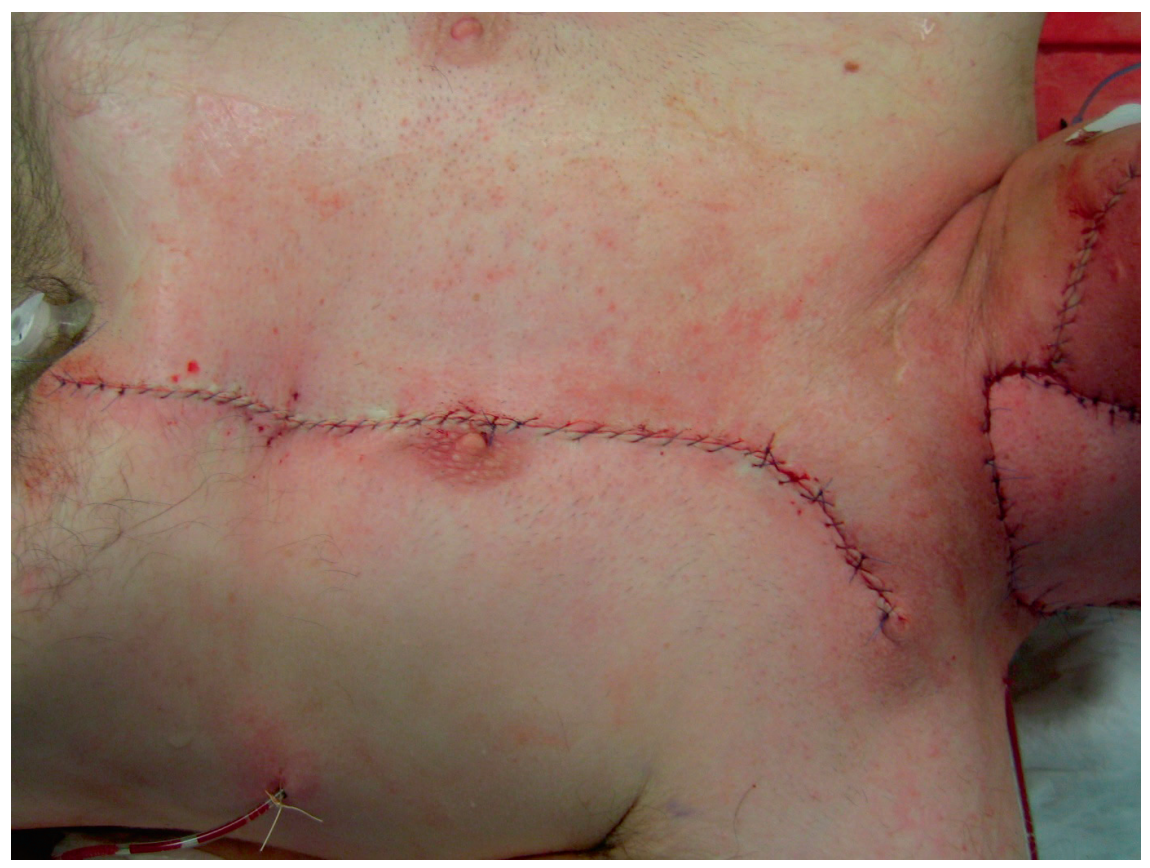

Primary closure of the donor site 


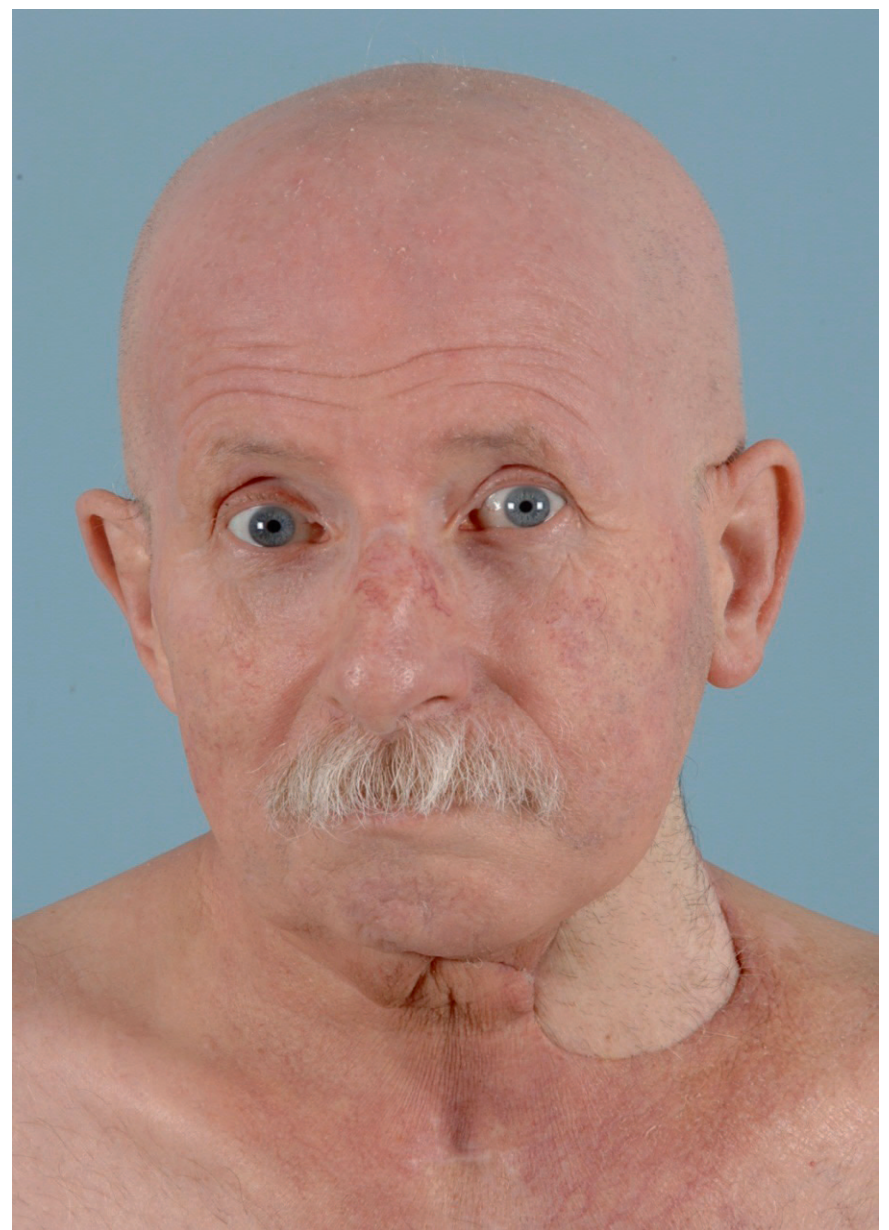

Final result. 


\section{Case F}

A 45-year-old man presented with a multilocular dermatofibrosarcoma protuberans in the left acromion-clavicular region. The tumor was resected together with the clavicular periosteum which resulted in a $10 \times 10 \mathrm{~cm}$ defect. A $10 \times 15 \mathrm{~cm}$ IMAP flap was dissected based on the second and third internal mammary artery perforators. Pedicle enhancement was obtained by mobilization of the internal mammary vessels and removal of the second and third rib cartilage and intercostal muscles. The flap was designed in a V-shaped fashion and after cranial transposition the donor site could be closed in a $\mathrm{V}$ to $\mathrm{Y}$ fashion with minimal displacement of the nipple-areola complex. The flap healed uneventfully and adjuvant radiation was executed without causing wound problems.

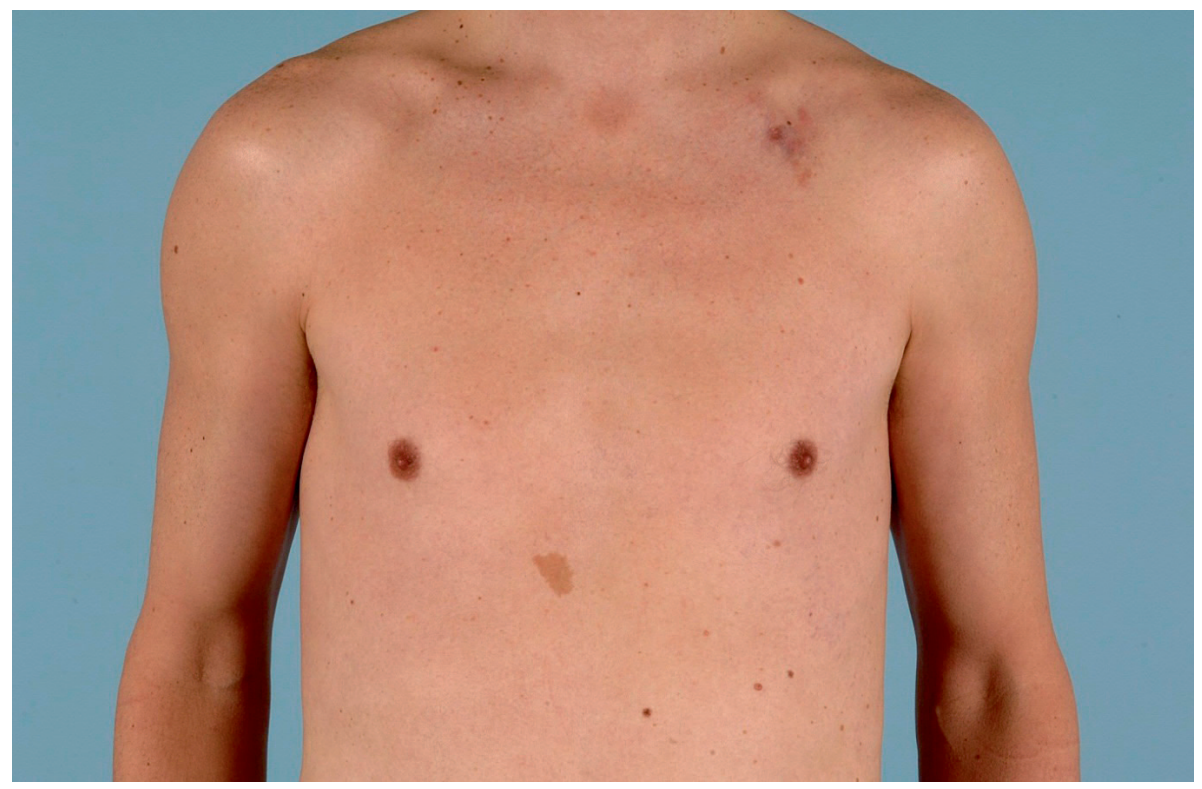




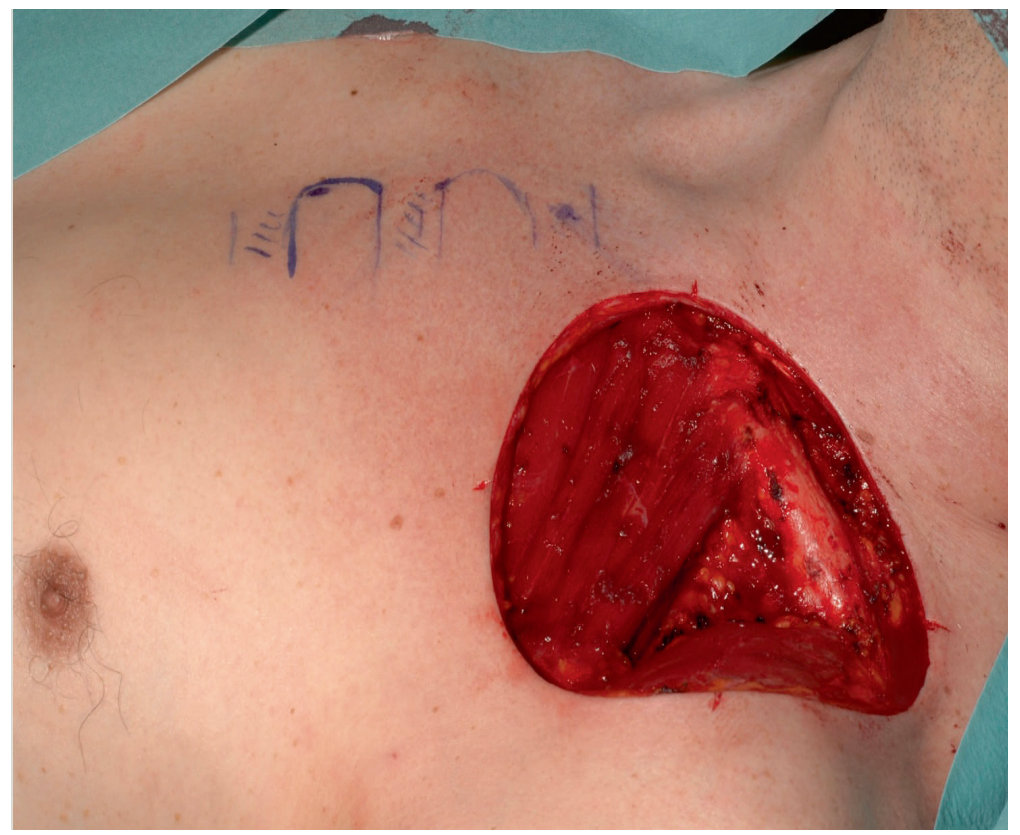

Defect with denuded clavicle.

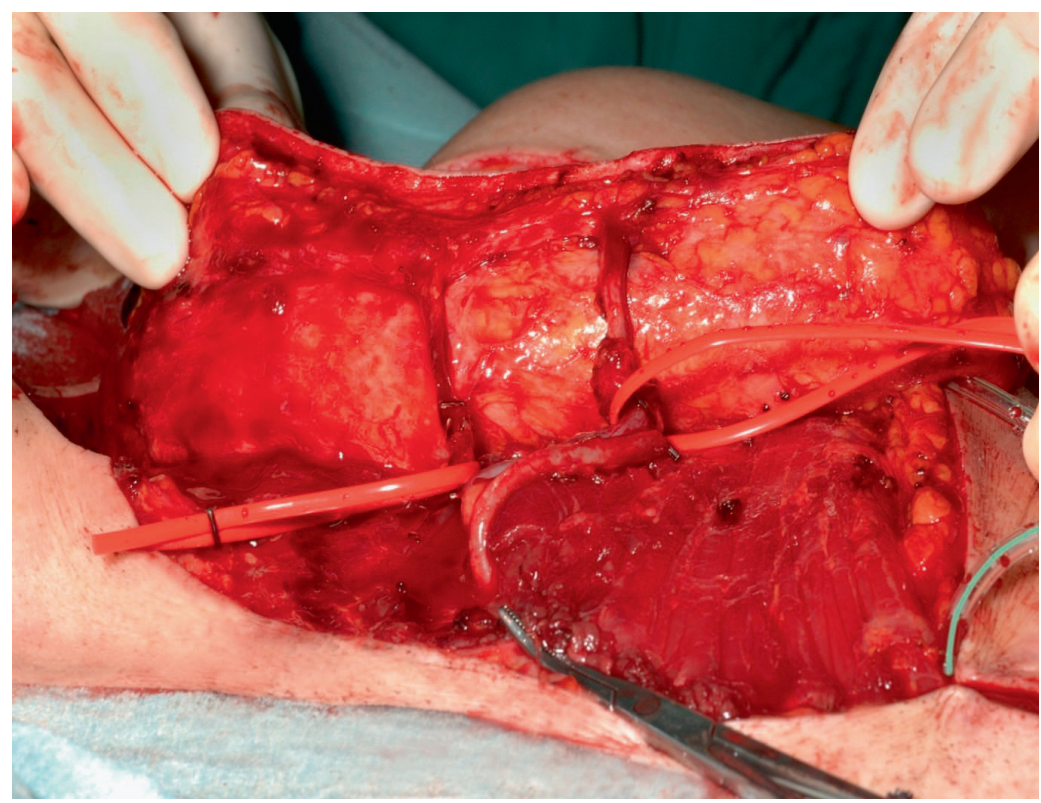

Transposed IMAP flap based on second and third intercostal perforator. Pedicle enhancement after distal clipping of internal mammary vessels. Mobilization of vascular pedicle by removal of second and third rib cartilage. Closure of splitted pectoralis major muscle performed. (Note: defect is located on the left side of the photo) 


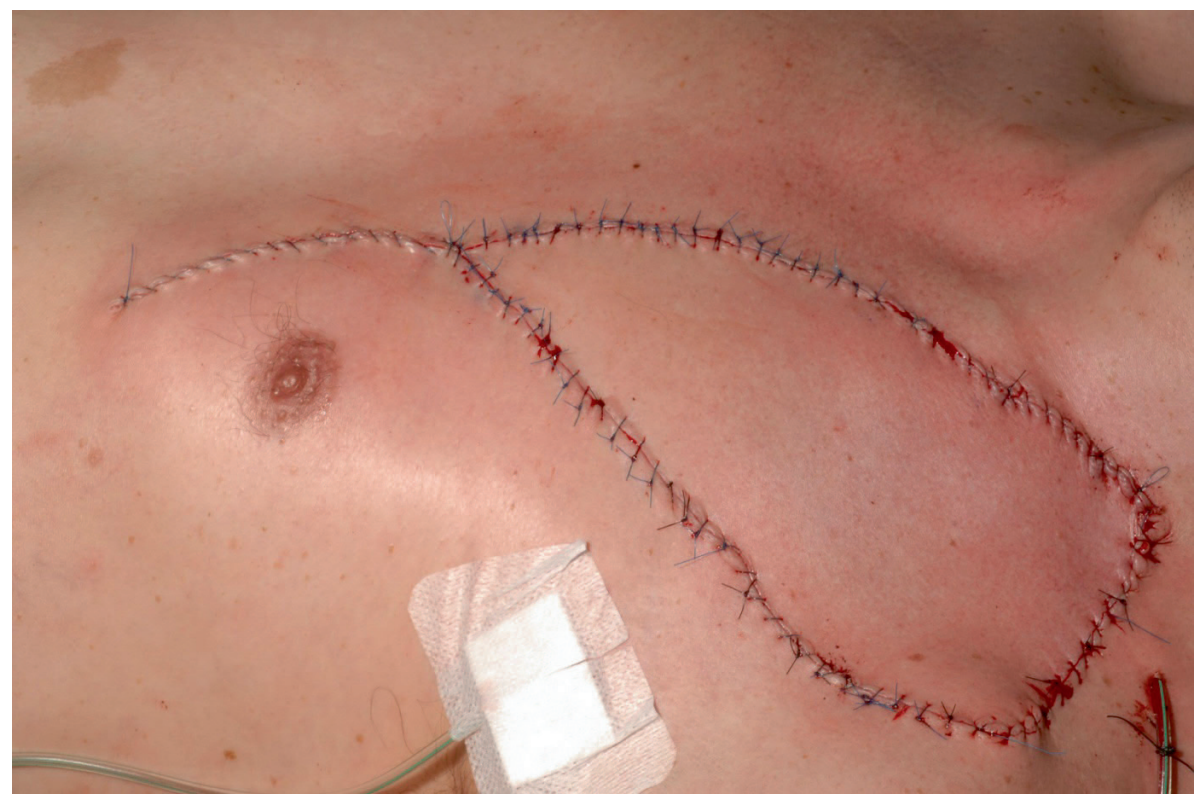

Insetting of the flap after V-Y advancement.

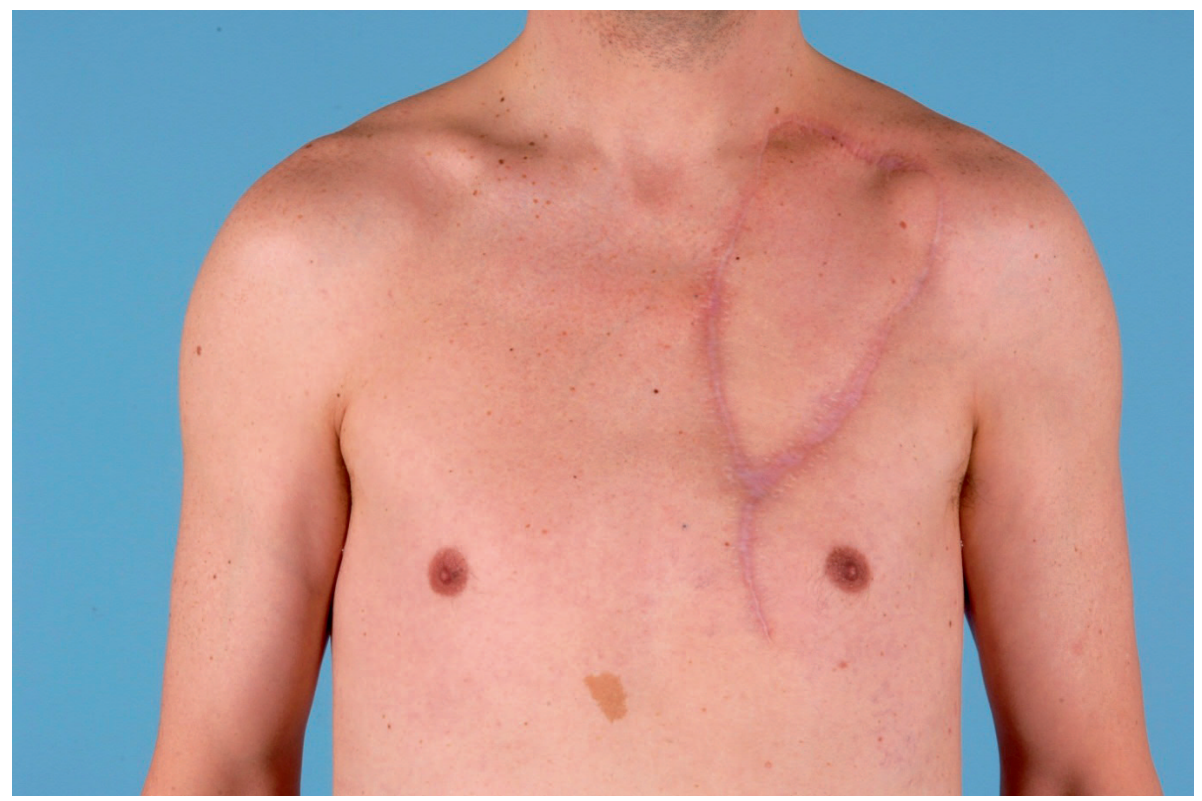

Final result with stable reconstruction after adjuvant radiotherapy. 


\section{Case G}

A 30-year-old woman was diagnosed with a dermatofibromasarcoma protuberans located on the sternum, medially of her right breast. The lesion was resected with wide margins including the periost of the sternum resulting in a $6 \times 13 \mathrm{~cm}$ defect. $A$ preoperative duplex analysis of the surrounding skin adjacent to the defect showed a distal IMA perforator. A $7 \times 14 \mathrm{~cm}$ skin flap was designed which extended over the mid upper part of the abdomen with the perforator at the cranial margin of the flap. The perforator was dissected out of the muscle without removal of rib cartilage. The flap was raised suprafascially and rotated $180^{\circ}$ clockwise to cover the defect. The donor site was closed primarily. Postoperative there was venous congestion of the distal 1/3 of the flap which was treated successfully by leech therapy for three days. The flap recovered well, resulting in an overall good result. The patient received adjuvant radiotherapy without compromise to the flap.

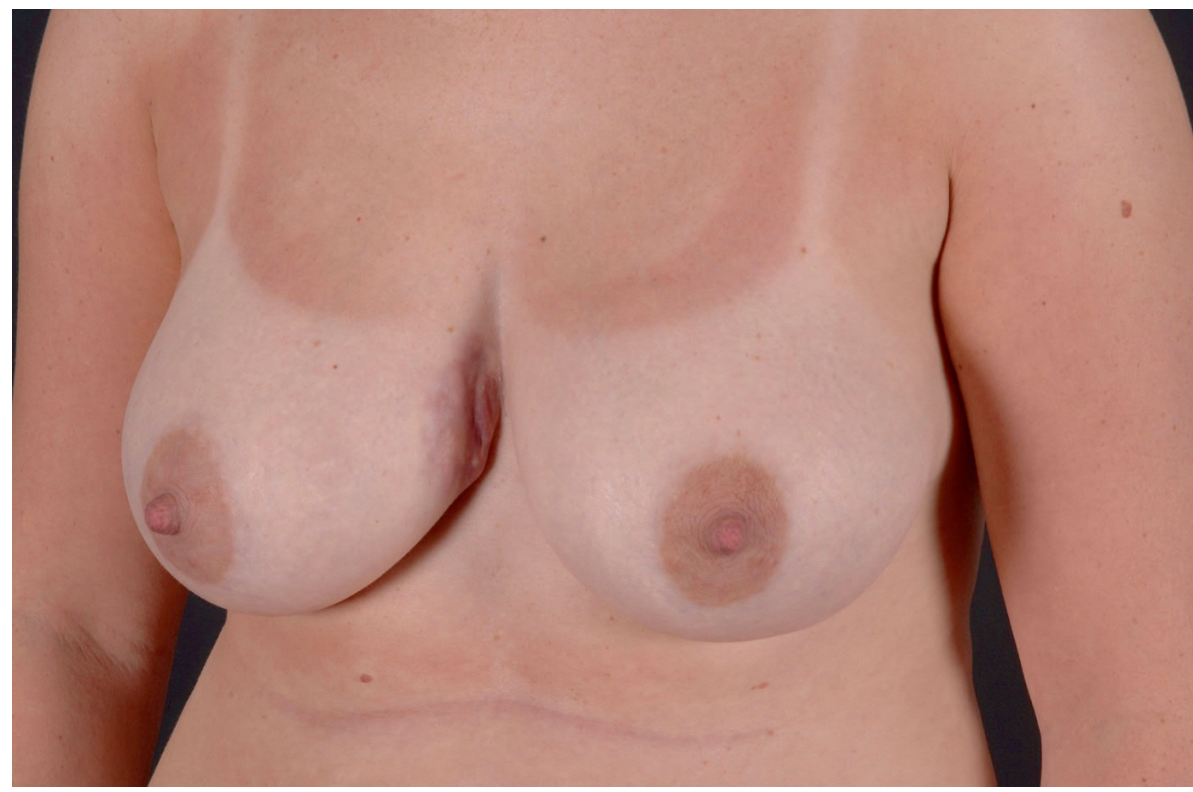




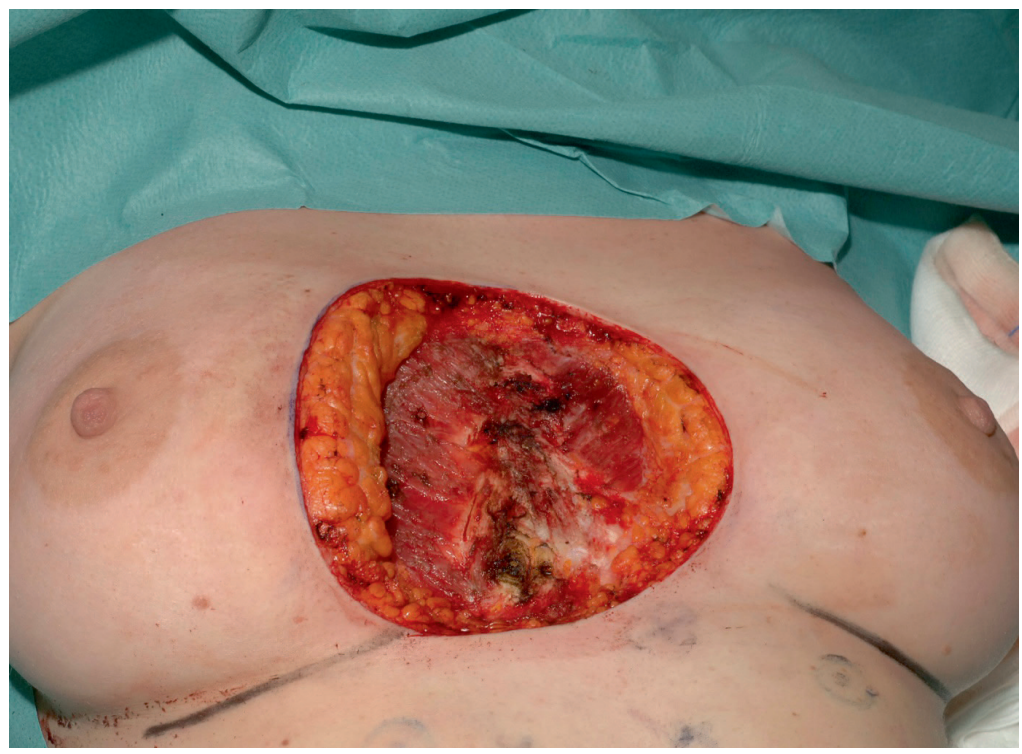

Defect after resection.

Perforator located near the left caudal border of the defect marked with " $\mathrm{X}$ ".

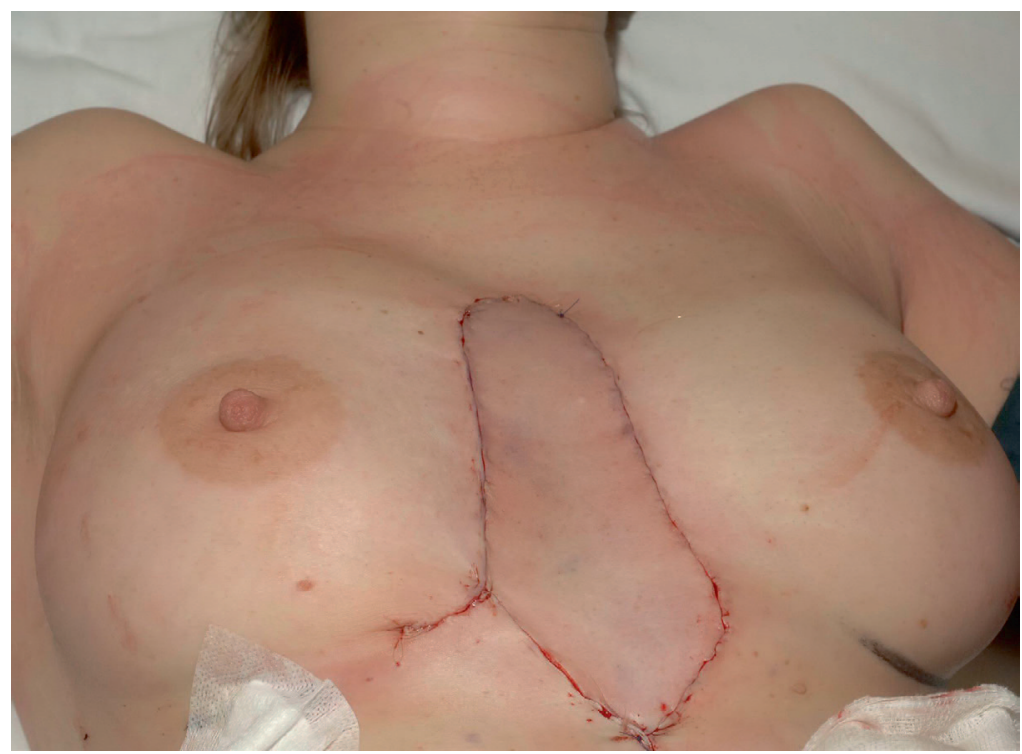

Insetting of the flap.

Postoperative distal $1 / 3$ of the flap showed venous congestion which was succesfully treated by leech therapy for three days. Flap survived completely. 


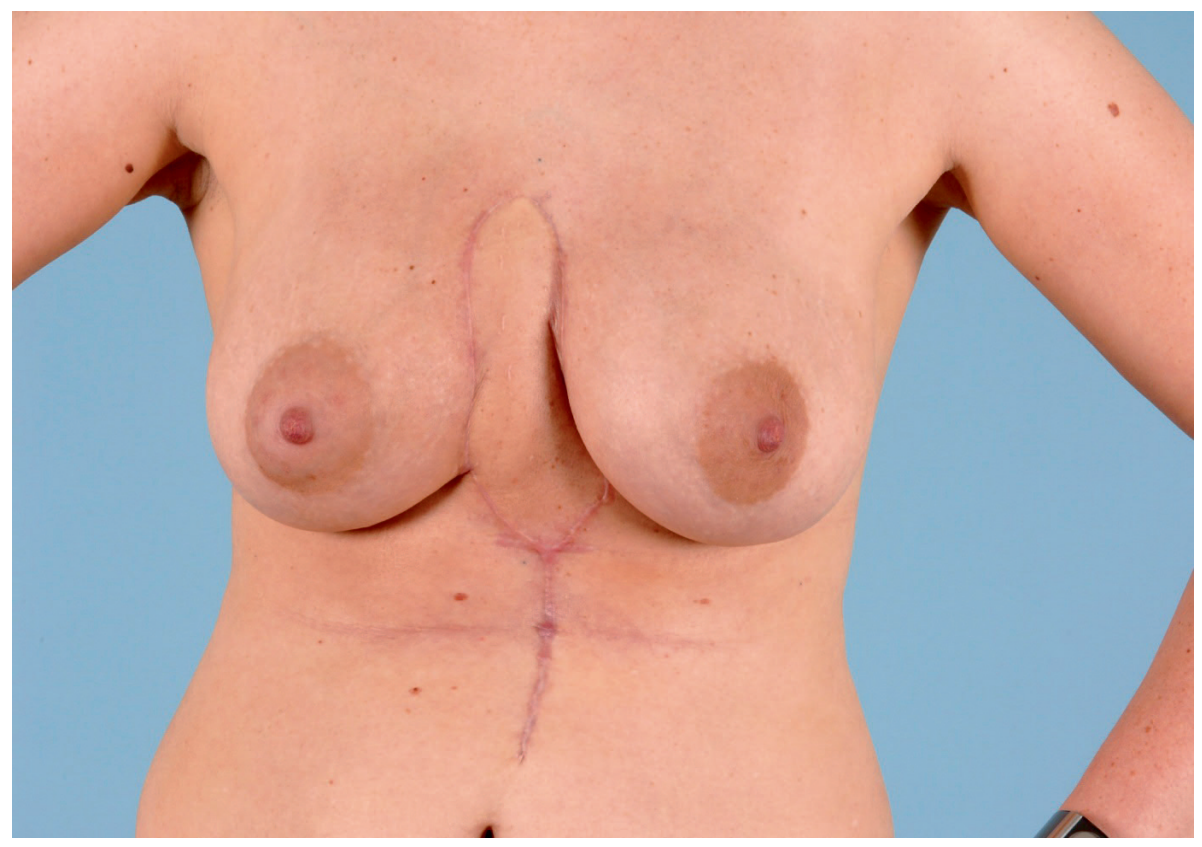

Final result after radiotherapy with good aesthetic outcome. 


\section{Chapter 5}

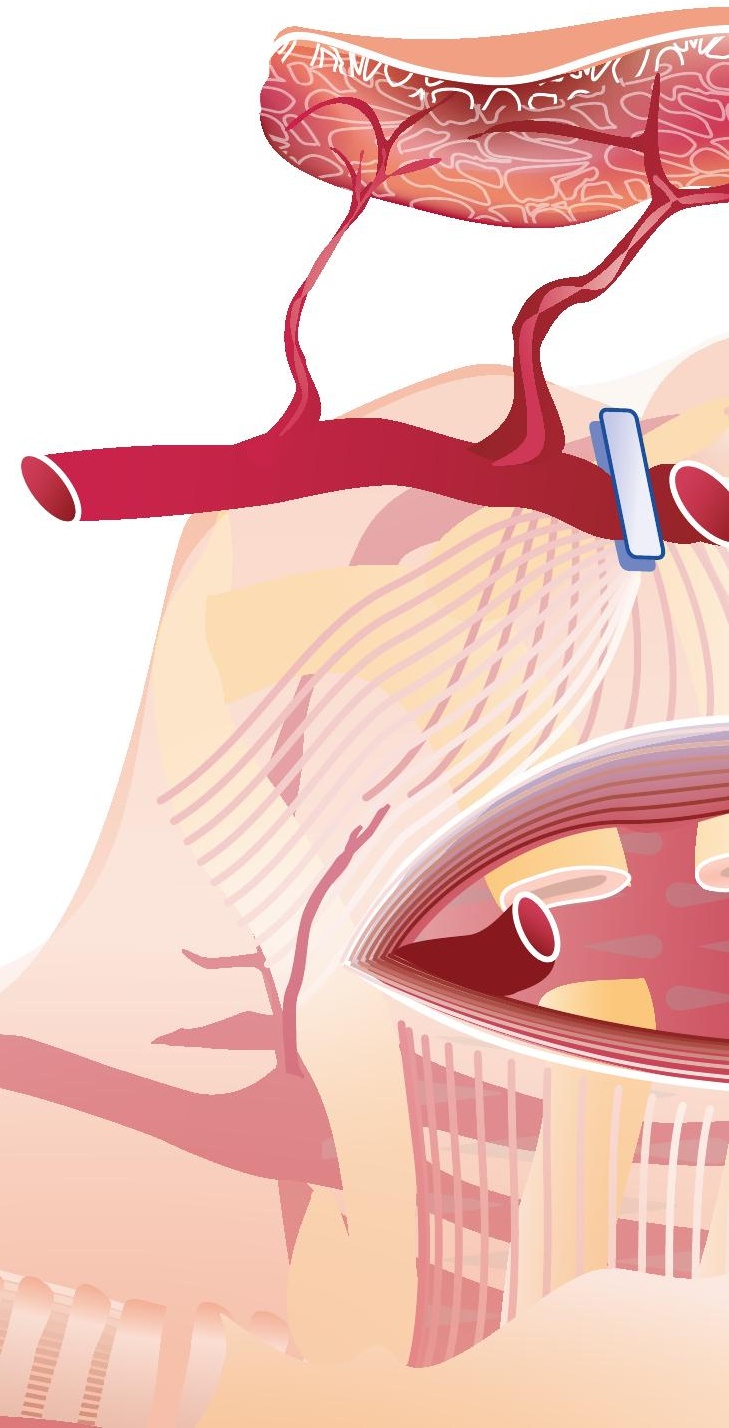




\section{Abstract}

\section{Background}

The fasciocutaneous internal mammary artery perforator (IMAP) island flap allows for superior aesthetical and functional skin cover in the head and neck region in combination with limited donor site morbidity. Its modification as a free flap allows reconstruction of more cranial defects.

\section{Patients and Methods}

Three IMAP free flaps varying from $7 \times 4 \mathrm{~cm}$ to $10 \times 6 \mathrm{~cm}$ were transplanted in three patients with a mean age of 59 years (range, $54-69$ years). Enhancement of the flap's vascular pedicle at least doubles the diameter of the internal mammary vessels to be anastomosed.

\section{Results}

Coverage with excellent texture and colour match was uneventfully obtained and the flaps' donor sites were primarily closed in all three cases.

\section{Conclusions}

Our experience proves the consistent feasibility of successful transplantation of the IMAP free flap. Because of its characteristics, we suggest contemplating the use of this flap in the upper head and neck region. 


\section{Introduction}

The internal mammary artery perforator (IMAP) island flap is a thin and pliable fasciocutaneous flap with superior contour adaptation and color match for head and neck reconstruction and an inconspicuous donor site that can be closed primarily in the majority of cases. ${ }^{1-6}$ Flap sizes up to $10 \mathrm{~cm}$ width and $25 \mathrm{~cm}$ length still allow for primary closure of the donor site (Table 1), and the length of its vascular pedicle may be enhanced up to $10.5 \mathrm{~cm} .^{7}$ This allows for easy use as a pedicled flap in the lower head and neck region, ${ }^{2-4,6}$ but still renders its application for the reconstruction of more cranial defects impossible. To overcome this limitation, we applied this flap as a free flap in three patients with oncological defects in the upper head and neck region. We present our clinical experience to suggest and promote the use of this free flap.

Table 1. Reported Clinical Cases of True Internal Mammary Artery Perforator Island Flaps

\begin{tabular}{|c|c|c|c|c|c|}
\hline Authors & Year & Cases & Indication & Flap size & $\begin{array}{l}\text { Donor site } \\
\text { closure }\end{array}$ \\
\hline Morain et al. ${ }^{1}$ & 2006 & 1 & Pharyngoesophageal defect & $5 \times 25 \mathrm{~cm}$ & Primary \\
\hline \multirow[t]{2}{*}{ Yu et al. ${ }^{2}$} & 2006 & 2 & Tracheostomy defect & $5 \times 13 \mathrm{~cm}$ & Primary \\
\hline & & & Anterior neck defect & $5 \times 12 \mathrm{~cm}$ & Primary \\
\hline \multirow[t]{2}{*}{ Vesely et al. ${ }^{3}$} & 2007 & 1 & Anterior neck defect & $7 \times 17 \mathrm{~cm}$ & Primary \\
\hline & & & Bilateral flaps used & $7 \times 17 \mathrm{~cm}$ & Primary \\
\hline Neligan et al. ${ }^{4}$ & 2007 & 1 & Anterior neck defect & $10 \times 11 \mathrm{~cm}$ & Primary \\
\hline Saint-Cyr et al. ${ }^{5}$ & 2009 & 1 & Anterior neck burn & $8 \times 12 \mathrm{~cm}$ & Tissue expander \\
\hline \multirow[t]{3}{*}{ lyer et al. ${ }^{6}$} & 2009 & 3 & Anterior neck defect & $5 \times 11 \mathrm{~cm}$ & Primary \\
\hline & & & Anterior neck defect & $6 \times 10 \mathrm{~cm}$ & Primary \\
\hline & & & Tracheostomy defect & $4 \times 10 \mathrm{~cm}$ & Primary \\
\hline
\end{tabular}

\section{Preoperative planning and surgical technique}

Preoperatively, the dominant IMAP was bilaterally detected on the basis of the strongest signal of a hand-held Doppler auscultatory device ${ }^{2,8}$ because its location is variable and depending on chest side, ${ }^{3}$ with only 40 to $69 \%$ of the dominant perforators reportedly located in the second intercostal space. ${ }^{7,9-12}$ A right-sided IMAP flap was preferred in order to save the left-sided internal mammary for possible future cardiac surgery. ${ }^{5,13}$ Based on the dominant IMAP, an island flap was marked infraclavicularly with its long axis orientated parallel to the corresponding intercostal space, and in accordance to the size of the recipient defect. Care was taken not to laterally extend the design past the anterior axillary fold. $3,5,14$ 
Peroperatively, the initial incision was made at the medial border of the flap to proceed laterally in a subfascial plane until the chosen IMAP was visualized. ${ }^{2}$ The degree of perfusion of the perforators was once more assessed by Doppler to assure the dominancy of this IMAP. ${ }^{2,4}$ Subsequently, the flap was circumferentially incised and raised from its distal edge toward the IMAP, turning it into a true island flap. In all three cases, the origin of the perforating vascular pedicle at the internal mammary artery and vein was dissected by parasternal dissection of the adjacent pectoralis major muscle fibers and resection of the intercostal muscles. To obtain a better view of the course of the internal mammary artery and vein, as well as to enhance the length of the vascular pedicle, the cartilage of the rib immediately cranially to the dominant IMAP was removed..$^{3,4,7}$ The internal mammary artery and vein were clipped and divided immediately distal to the origin of the perforator. ${ }^{3,4}$ This mobilization of the vascular pedicle led to an increase of the length of the donor vessels and better match of their diameter to the recipient vessels. After transection, we flushed the donor and recipient vessels with heparinized water and, following micro-anastomosis at the recipient site, these vessels were soaked with papaverine $30 \mu \mathrm{g} / \mathrm{ml}$. The soft tissue defect resulting from cartilage resection and muscle splitting was subsequently obliterated by suturing of the pectoral muscle to the lateral edge of the sternum..$^{13}$ In all cases, the donor site was closed primarily without need of a skin graft and no rehabilitation because of the resection of costal cartilage or partial dissection of the pectoralis major muscle was required.

\section{Case Reports}

\section{Case 1}

A 55-year-old women presented with chronic osteomyelitis of the frontal bone, six years after resection, orbit exenteration, nose-amputation and adjuvant radiotherapy of an ulcerating basal cell cancer of the left cheek. Initial reconstruction had been performed with a free TRAM-flap and local flaps had unsuccessfully been tried to treat the osteomyelitis (Fig. 1A). Debridement of the frontal bone and excision of the instable skin left a $7 \times 4 \mathrm{~cm}$ defect. Use of local flaps was felt to be inadequate because of previous radiotherapy. 
The vascular pedicle of a $7 \times 4 \mathrm{~cm}$ flap based on the second right-sided IMAP was enhanced up to $9 \mathrm{~cm}$ by dissection up to the inferior border of the first rib cartilage (Figs. 1B and C). The internal mammary artery was subsequently anastomosed end-toend to the deep inferior epigastric artery of the previously inserted TRAM flap. Venous outflow was ensured using a greater sapheneous vein graft to reach the left facial vein. The postoperative course was uneventful and the patient was without residual infection, eight months after surgery (Figs. 1D and E).
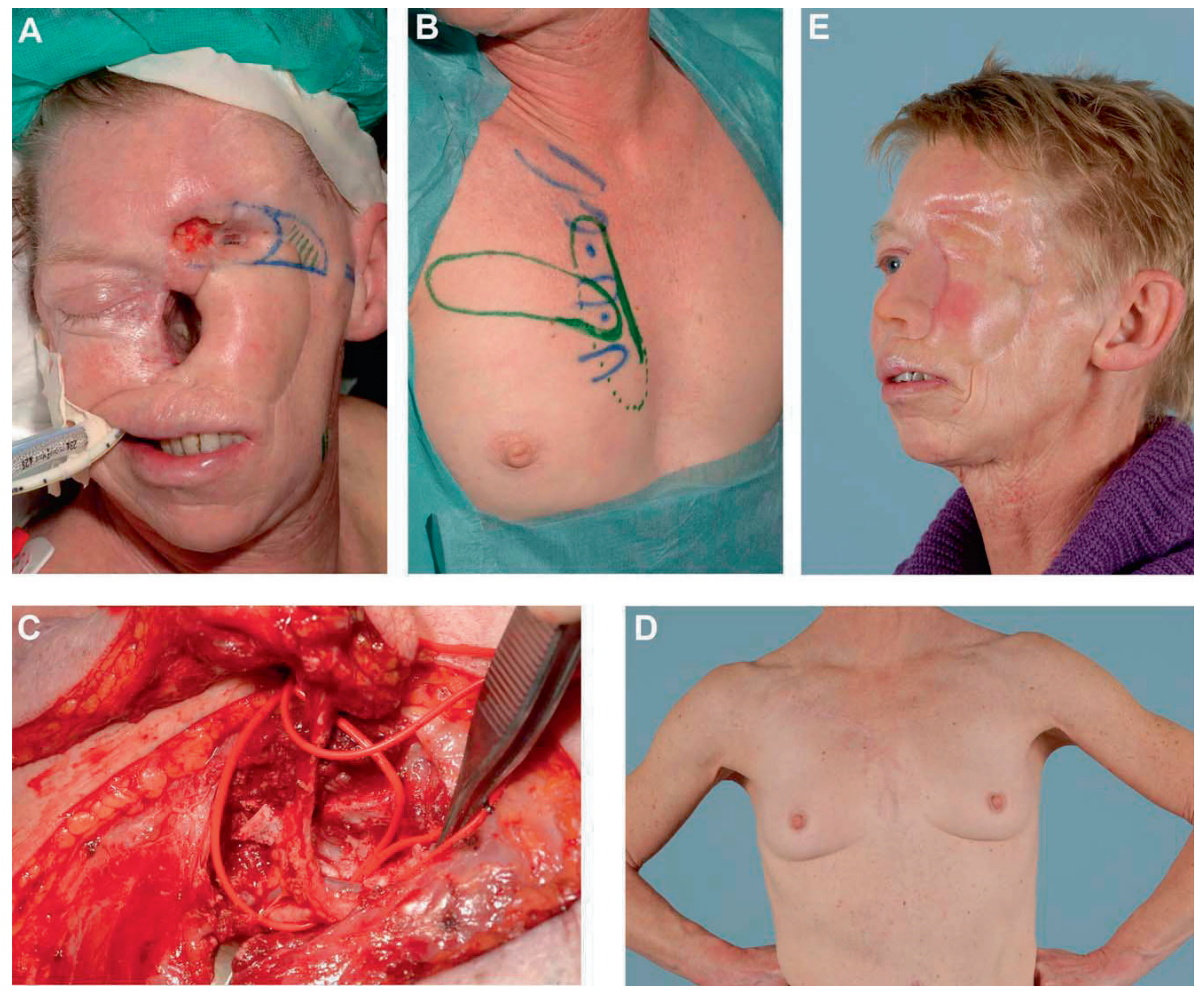

Figure 1: Preoperative view of the recipient site in Case $1(A)$. Peroperative view of the donor site of the right-sided second IMAP flap (B). Its vascular pedicle was enhanced up to $9 \mathrm{~cm}$ by dissection up to the inferior border of the first rib cartilage (C). The donor site was closed primarily without disfigurement of the breast or thorax (D). Result with nasal epithesis, 8 months after surgery (E). 


\section{Case 2}

Radical parotidectomy including the cartilage part of the outer auditory canal and lymph node dissection was performed in a 59-year-old man presenting with a $7 \times 5 \mathrm{~cm}$ epithelial myo-epithelial carcinoma of his left infra-auricular area (Fig. 2A). Although we had preoperatively planned to reconstruct the defect with a submental flap, the tumor resection left us with a severed facial artery and no available submental pedicle. The facial nerves, however, had been spared. A $10 \times 6 \mathrm{~cm}$, oval flap based on the second IMAP was dissected over the right second intercostal space. The vascular pedicle could be enhanced up to $5.5 \mathrm{~cm}$ by inclusion of an extra $3 \mathrm{~cm}$ of the internal mammary artery and vein after resection of all cartilage of the second rib and the superior part of the third rib cartilage, and was easily anastomosed end-to-end to the stump of the left facial artery and end-to-side to the left internal jugular vein. The flap healed uneventful and adjuvant radiotherapy was planned but the patient refused further treatment (Figs. 2B). Eighteen months after surgery, the patient was terminally ill.

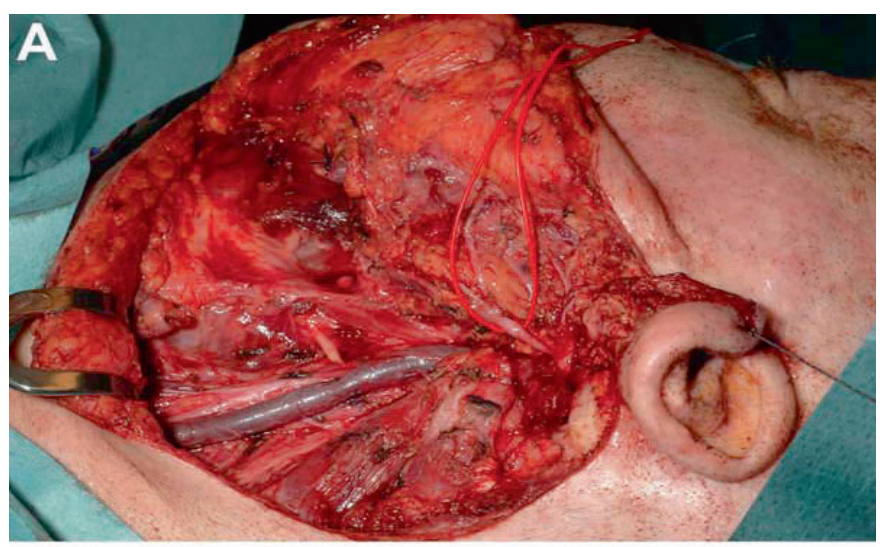




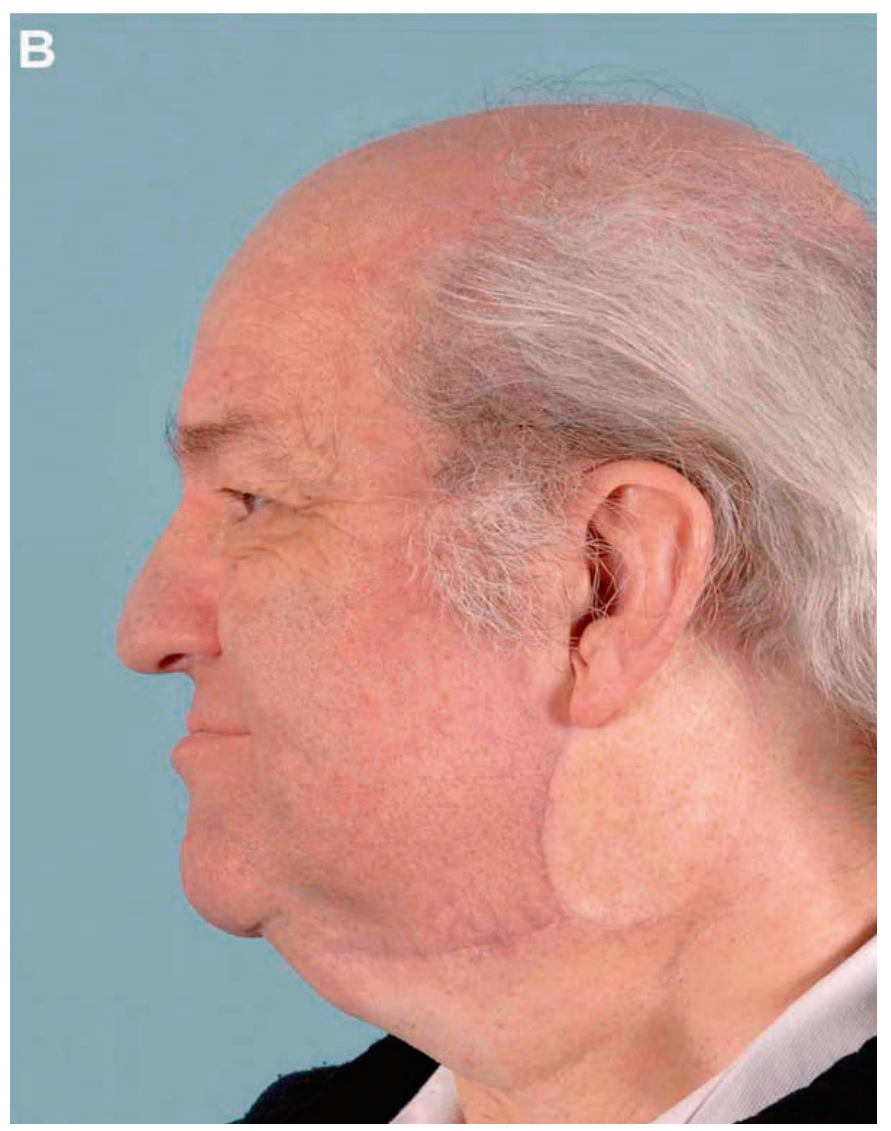

Peroperative view of the left-sided recipient site in Case 2 (A). Postoperative view of the recipient site of the right-sided second IMAP flap anastomosed to the left facial artery and left internal jugular vein (B). 


\section{Case 3}

A 63-year-old man underwent ear amputation, subtotal petrosectomy, superficial parotidectomy and lymph node dissection for a deeply invading squamous cell carcinoma of his right auditory canal. Because of the neck dissection, use of a submental or supraclavicular flap was no longer judged a safe option. Hence, the defect was closed using a $7 \times 5 \mathrm{~cm}$ free perforator flap based on the right second IMAP that was enhanced up to $4.5 \mathrm{~cm}$ by resection of the cartilage of the second rib (Fig. 3A). The internal mammary artery and vein were subsequently anastomosed end-to-end to the external carotid artery and end-to-side to the internal jugular vein, respectively. Histopathologically, the $1 \mathrm{~cm}$ large moderately differentiated squamous cell carcinoma was found to infiltrate the mastoid and irradically resected at the deep end of the external auditory canal. The postoperative course was uneventful and the flap sustained adjuvant radiotherapy well (Figs. 3B). Follow-up currently amounts to thirty months.

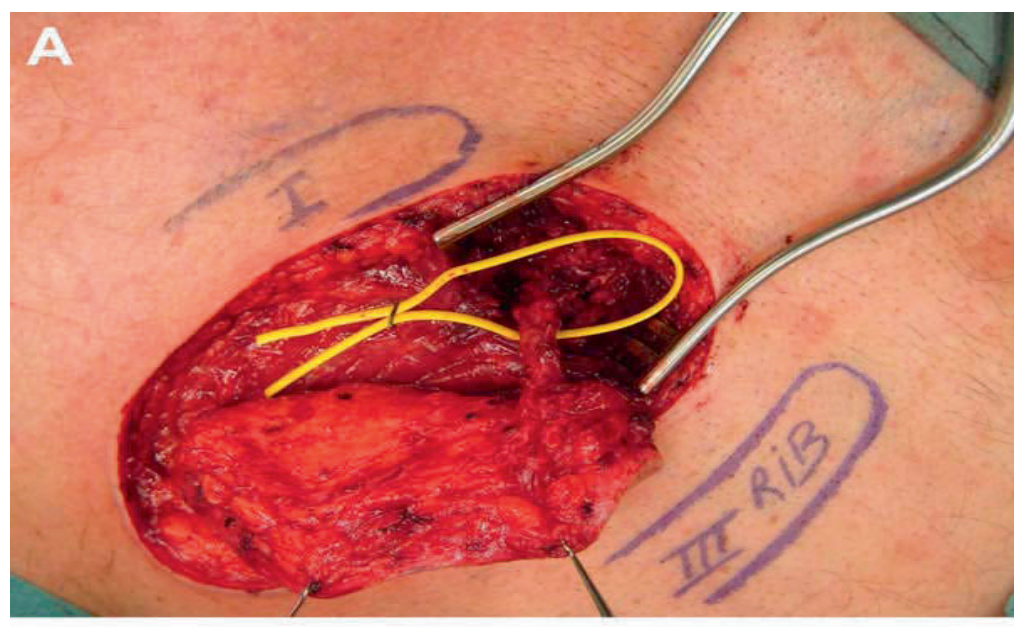




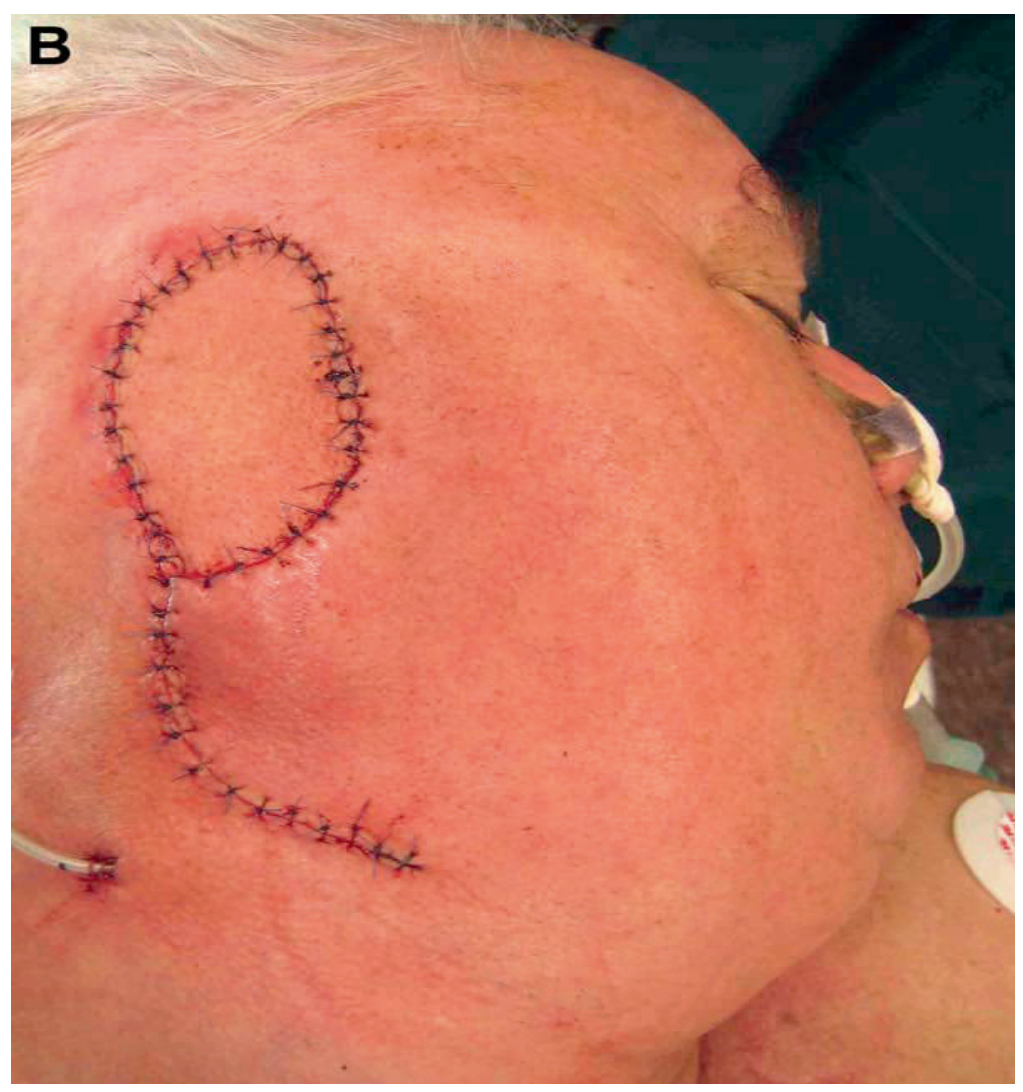

Peroperative view of the right-sided second IMAP flap (A). Postoperative view of closure of the defect after radical resection of the right auditory canal (B). 


\section{Discussion}

Although Morain et al. ${ }^{1}$ and Neligan et al. ${ }^{4}$ suggested transferring the IMAP flap as a free flap if it is intended to cover a defect beyond the reach of its pedicled version, Yu et al. objected against such use because they felt that the vascular pedicle would not be long enough and the area of skin provided, not large enough. ${ }^{2}$ Like others, ${ }^{3,5,15,16}$ we previously concluded from cadaver studies that the pedicle length can be doubled by including part of the internal mammary vessels and that the area vascularized by the dominant IMAP may extend from midsternal to the anterior axillary line and from the clavicula to the inferior costal arch. ${ }^{71}{ }^{14}$ Saint-Cyr et al. ${ }^{5}$ recently showed that the flap may even be pre-expanded to allow for even larger donor sites to be closed primarily. Even though the perforating branches have been used for microvascular anastomosis in selected patients, ${ }^{10,13,16-18}$ inclusion of extra pedicle length increases the reliability of such anastomosis as the diameter of the internal mammary vessels is known to be at least twice as large as that of the perforators. $3,9,12,13,15$ Hence, in cases where the vascular pedicle can be enhanced this way, there should not be a reason to reject such use of the IMAP flap. We have now proven the clinical consistent feasibility of the IMAP flap as a free flap.

The IMAP free flap should not be confused with the deltopectoral fasciocutaneous free flap, ${ }^{15,}{ }^{19-21}$ even though the $2^{\text {nd }}$ and $3^{\text {rd }}$ perforating branch of the internal mammary vessels are used for the vascular pedicle in both. Unlike the deltopectoral free flap, the donor site of the IMAP flap is chosen either parasternally or overlying the intercostal space immediately adjacent to the included IMAP, rather than parallel to the clavicle., Furthermore, the IMAP flap is limited laterally to anterior axillary line in accordance to the internal mammary angiosome, rather than extended over the deltoid region. ${ }^{9}, 14$ These two characteristics represent the distinct difference between both flaps ${ }^{6}$ and allow for the IMAP flap donor site to be closed primarily without the need of skin grafting, in most patients. ${ }^{1-6}$ In women, the orientation and size of the flap may need to be adjusted to prevent distortion of the breast or inclusion of mammary tissue in the flap.

Compared to more distant free flaps, the potential disadvantages of the IMAP free flap include the possible sequences of costal cartilage resection, ${ }^{7}$ possible hair growth in male patients in whom the recipient site is not irradiated postoperatively, and the difficulty of simultaneous oncological resection and flap harvesting. Being a regional cutaneous flap, the IMAP flap addresses all requirements for optimal replacement of the original skin cover. It is superior to more distant free flaps in its texture and color match. Although our experience was limited to three patients of Caucasian descent, 
we surmise the same to apply in patients of Asian or African descent. Because of the region's limited subcutaneous thickness, its volume and adaptation to the recipient site contour are favorable and, moreover, the IMAP flap does not require any peroperative adjustment of the position of the head and neck oncological patient. Although we have not tried it yet, it seems feasible to include rib cartilage or bone with the IMAP flap, rendering this flap a potential alternative for midface reconstruction not involving patient positioning issues.

\section{Conclusions}

With this report on three clinical cases, we prove that consistently successful transplantation of the internal mammary artery perforator (IMAP) free flap is clinically feasible. Because of its superior mimicking of the characteristics of the regional integument, we suggest contemplating the use of this flap for reconstructions of cutaneous defects in the upper head and neck region. 


\section{References}

1. Morain WD, Hallock GG, Neligan PC. Internal mammary artery perforator flap. Blondeel PN, Morris SF, Hallock GG, Neligan PC, eds. Perforator Flaps - Anatomy, Technique \& Clinical Applications. St. Louis, Missouri: Quality Medical Publishing, 2006. pp. 429-439.

2. Yu P, Roblin P, Chevray P. Internal mammary artery perforator (IMAP) flap for tracheostoma reconstruction. Head Neck. 28: 723-9, 2006.

3. Vesely MJ, Murray DJ, Novak CB, Gullane PJ, Neligan PC. The internal mammary artery perforator flap: an anatomical study and a case report. Ann Plast Surg. 58, 156- 161, 2007.

4. Neligan PC, Gullane PJ, Vesely M, Murray D. The internal mammary artery perforator flap: new variation on an old theme. Plast Reconstr Surg. 119, 891- 893, 2007.

5. Saint-Cyr M, Schaverien M, Rohrich RJ. Preexpanded second intercostal space internal mammary artery pedicle perforator flap: case report and anatomical study. Plast Reconstr Surg. 123, 16591664, 2009.

6. Iyer NG, Clark JR, Ashford BG. Internal mammary artery perforator flap for head and neck reconstruction. ANZ J Surg.79, 799-803, 2009.

7. Schellekens PPA, Paes EC, Hage JJ, van der Wal MBA, Bleys RLAW, Kon M. Anatomy of the vascular pedicle of the internal mammary artery perforator (IMAP) flap as applied for head and neck reconstruction. J Plast Reconstr Aesthet Surg. 64, 53-57, 2010.

8. Taylor GI, Doyle M, McCarten G. The Doppler probe for planning flaps: anatomical study and clinical applications. Br J Plast Surg. 43, 1-16, 1990

9. Palmer JH, Taylor Gl. The vascular territories of the anterior chest wall. Br J Plast Surg. 39, 287$299,1986$.

10. Munhoz AM, Ishida LH, Montag E, Sturtz GP, Saito FL, Rodrigues L, Gemperli R, Ferreira MC. Perforator flap breast reconstruction using internal mammary perforator branches as a recipient site: an anatomical and clinical analysis. Plast Reconstr Surg. 114, 62-68, 2004.

11. Rosson GD, Holton LH, Silverman RP, Singh NK, Nahabedian MY. Internal mammary perforators: a cadaver study. J Reconstr Microsurg. 21, 239- 242, 2005.

12. Saint-Cyr M, Chang DW, Robb GL, Chevray PM. Internal mammary perforator recipient vessels for breast reconstruction using free TRAM, DIEP, and SIEA flaps. Plast Reconstr Surg.120, 1769-1773, 2007.

13. Hamdi M, Blondeel $\mathrm{P}$, Van Landuyt $\mathrm{K}$, Monstrey S. Algorithm in choosing recipient vessels for perforator free flap in breast reconstruction: the role of the internal mammary perforators. $\mathrm{Br} J$ Plast Surg. 57, 258-265, 2004.

14. Paes EC, Schellekens PPA, Hage JJ, van der Wal MBA, Bleys RLAW, Kon M. A cadaver study of the vascular territories of dominant and non-dominant internal mammary artery perforators. Ann Plast Surg. 67, 68-72, 2011.

15. Sasaki K, Nozaki M, Honda T, Morioka K, Kikuchi Y, Huang T. Deltopectoral skin flap as a free skin flap revisited: further refinement in flap design, fabrication, and clinical usage. Plast Reconstr Surg.107, 1134-1141, 2001.

16. Schmidt M, Aszmann OC, Beck H, Frey M. The anatomical basis of the internal mammary artery perforator flap: a cadaver study. J Plast Reconstr Aesthet Surg. 63, 191-196, 2010.

17. Park MC, Lee JH, Chung J, Lee SH. Use of internal mammary vessel perforator as a recipient vessel for free TRAM breast reconstruction. Ann Plast Surg. 50, 132-137, 2003.

18. Haywood RM, Raurell A, Perks AG, Sassoon EM, Logan AM, Phillips J. Autologous free tissue breast reconstruction using the internal mammary perforators as recipient vessels. Br J Plast Surg. 56, 689-691, 2003.

19. Harii K, Omori K, Omori S. Free deltopectoral skin flaps. Br J Plast Surg. 27, 231- 239, 1974.

20. Harii K, Omori K, Omori S. Successful clinical transfer of ten free flaps by microvascular anastomoses. Plast Reconstr Surg. 53: 259-270, 1974.

21. Portnoy WM, Arena S. Deltopectoral island flap. Otolaryngol Head Neck Surg. 111, 63-69, 1994. 


\section{Addendum}

\section{Case 1}

A 55-year-old women presented with chronic osteomyelitis of the frontal bone, six years after resection, orbit exenteration, nose-amputation and adjuvant radiotherapy of an ulcerating basal cell cancer of the left cheek. Initial reconstruction had been performed with a free TRAM-flap and local flaps had unsuccessfully been tried to treat the osteomyelitis. Debridement of the frontal bone and excision of the instable skin left a 7 x $4 \mathrm{~cm}$ defect. Use of local flaps was felt to be inadequate because of previous radiotherapy.

The vascular pedicle of a $7 \times 4 \mathrm{~cm}$ flap based on the second right-sided IMAP was enhanced up to $9 \mathrm{~cm}$ by dissection up to the inferior border of the first rib cartilage. The internal mammary artery was subsequently anastomosed end-to-end to the deep inferior epigastric artery of the previously inserted TRAM flap. Venous outflow was ensured using a greater sapheneous vein graft to reach the left facial vein. The postoperative course was uneventful and the patient was without residual infection, eight months after surgery.

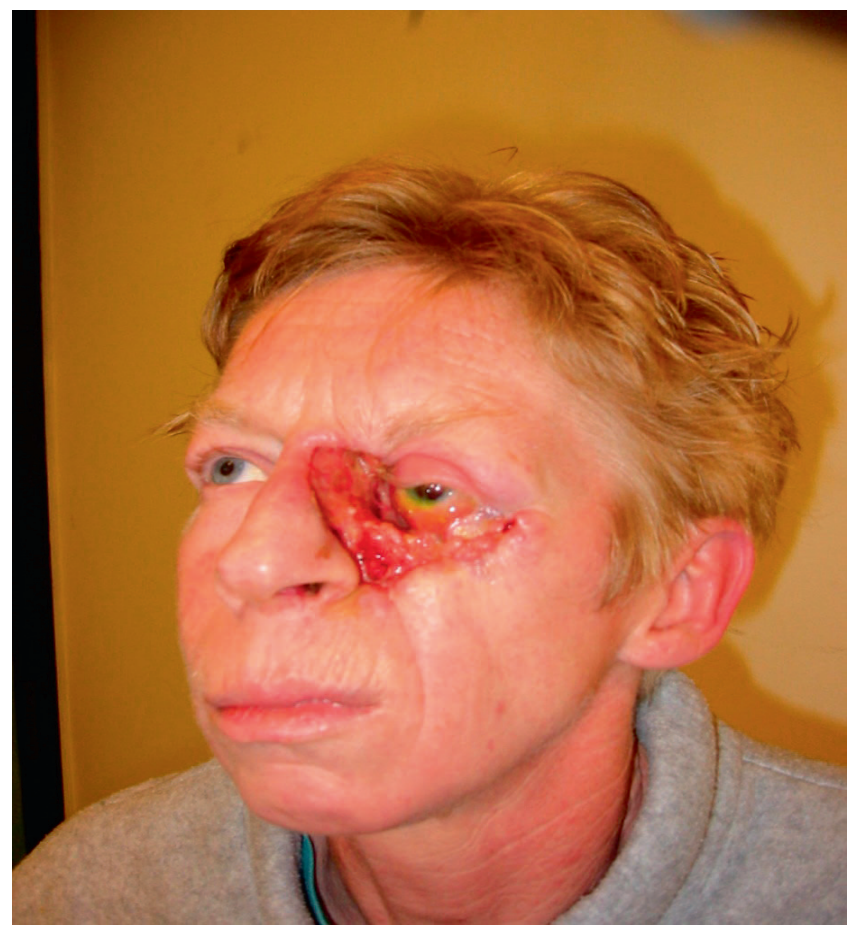

Patient upon presentation with ulcerating basal cell carcinoma of the left orbit (2003) 


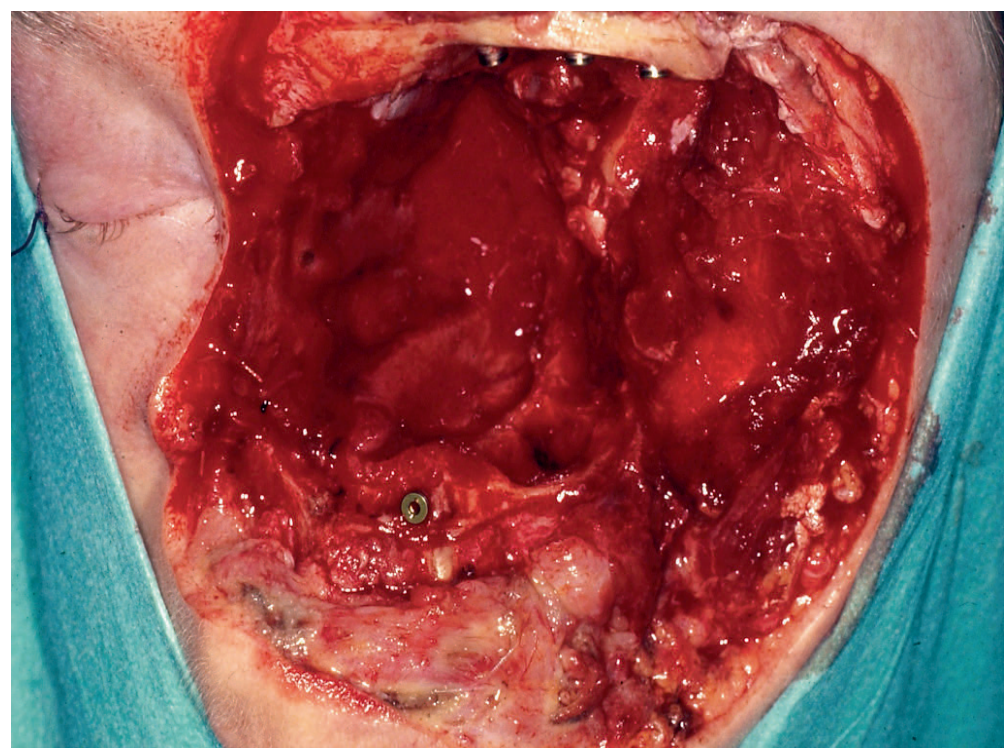

Initial treatment (2003) consisted of orbit exenteration, nose amputation and reconstruction with free TRAM flap. Osteo-integrated implants placed in frontal bone and maxilla.

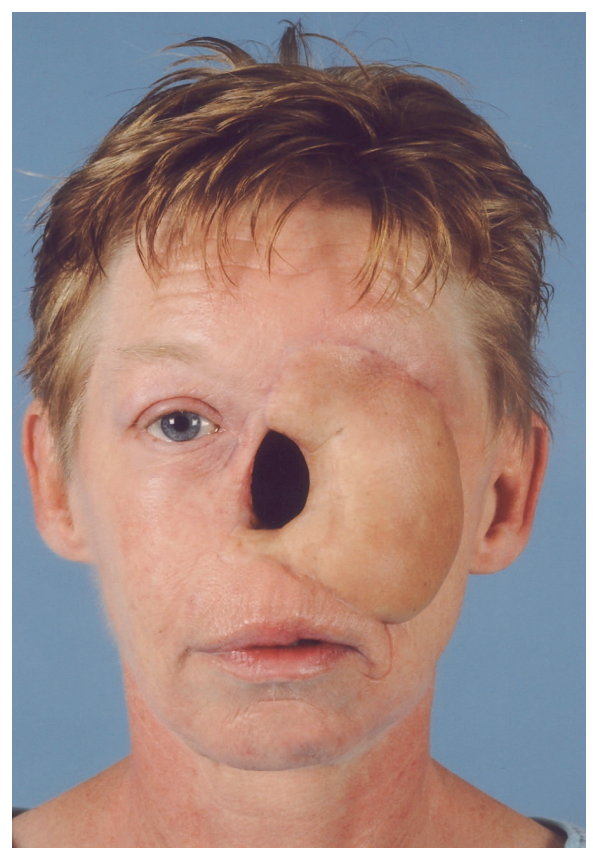

Result after radiotherapy. 


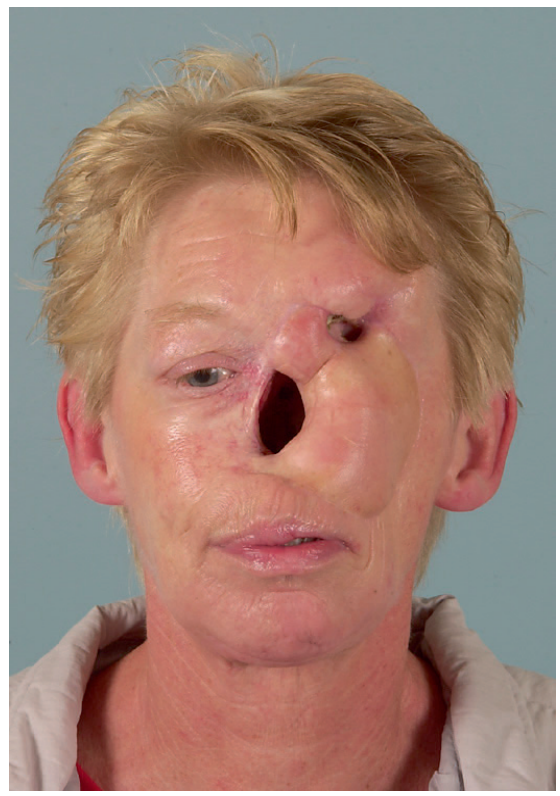

Chronic osteomyelitis of frontal bone. Initial treatment consisted out of debridement and local flaps.

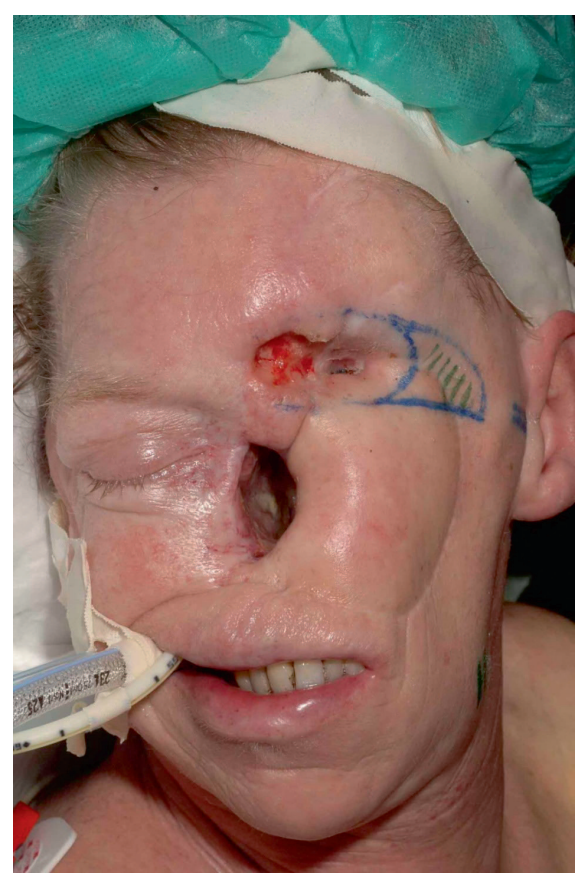

Persistent osteomyelitis of frontal bone (2009). 


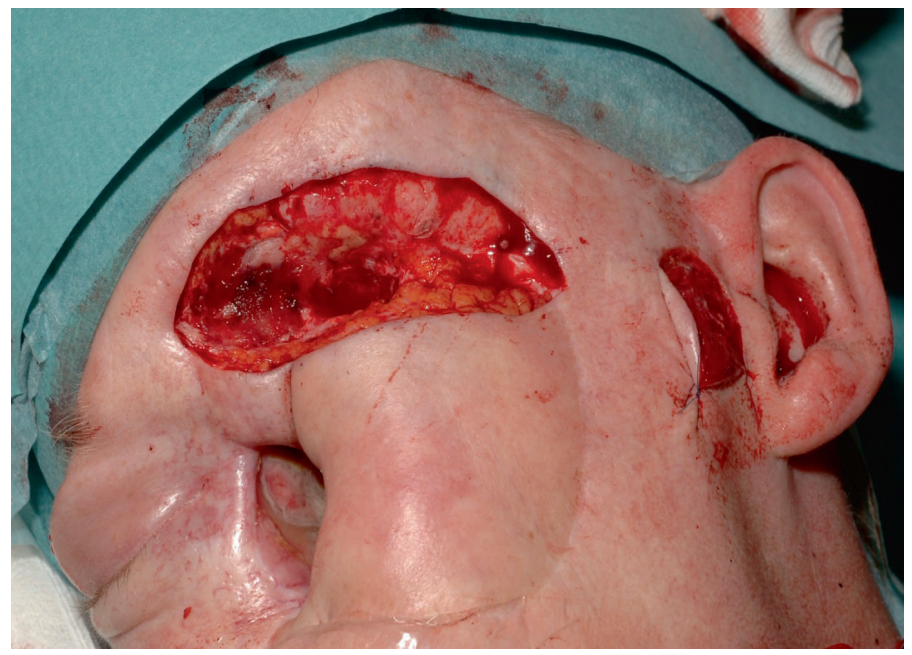

Debridement of necrotic frontal bone, exposure of previous pedicle of free TRAM flap (right side of photo).

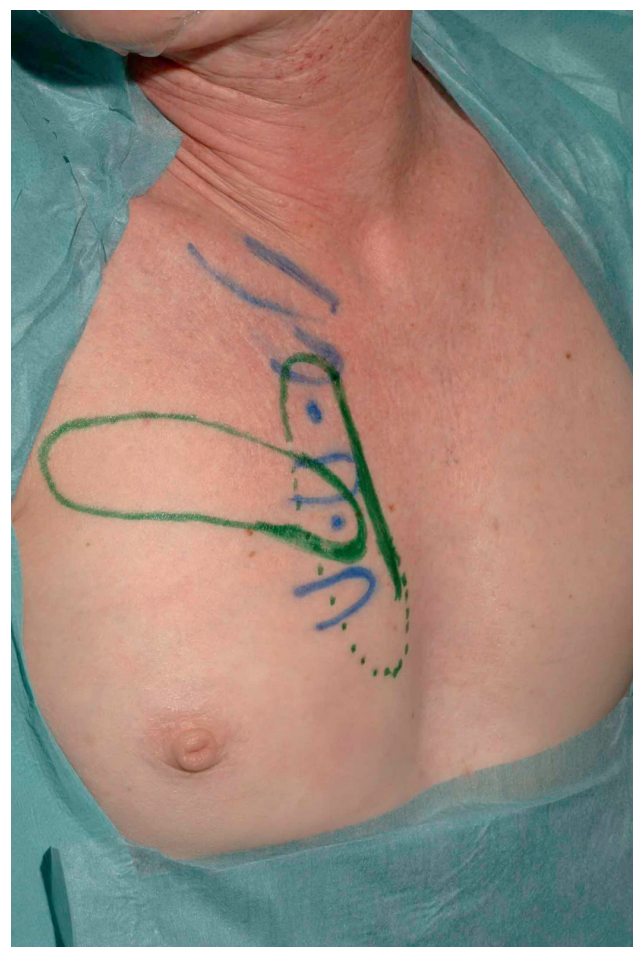

Design of IMAP flap based on dominant second internal mammary artery perforator. 


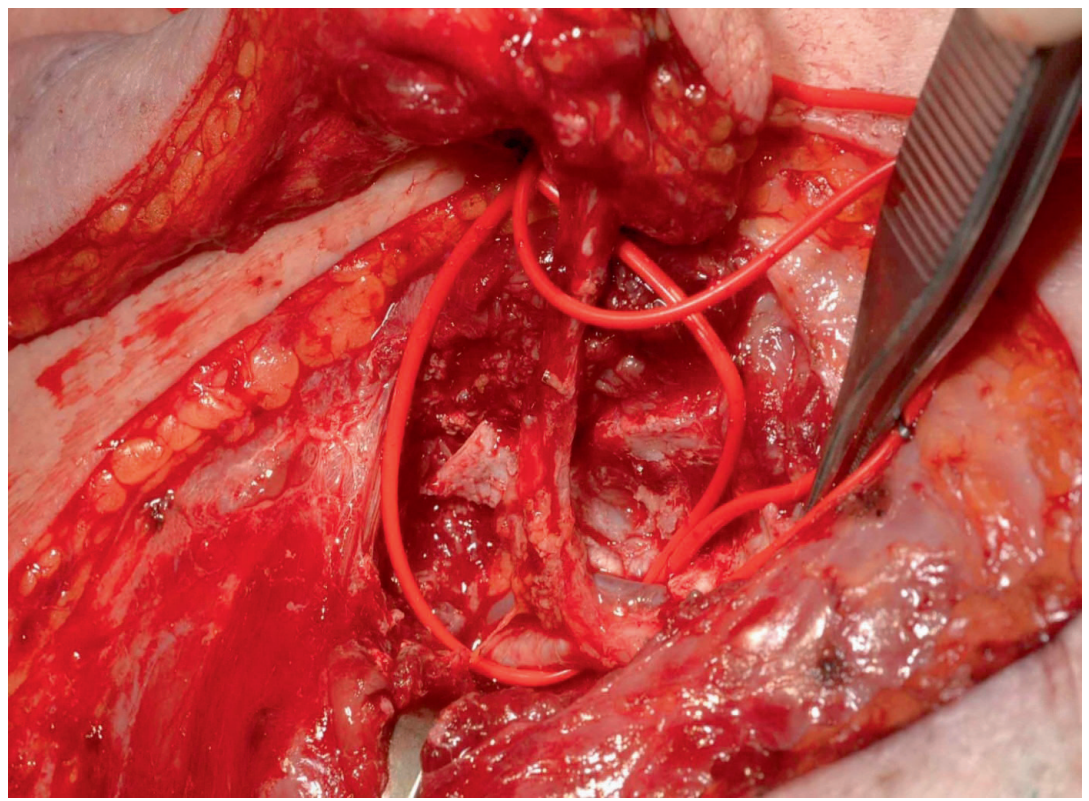

Pedicle enhancement by removal of second rib cartilage and intercostal muscle. Mobilization of internal mammary vessels up to the first rib cartilage.

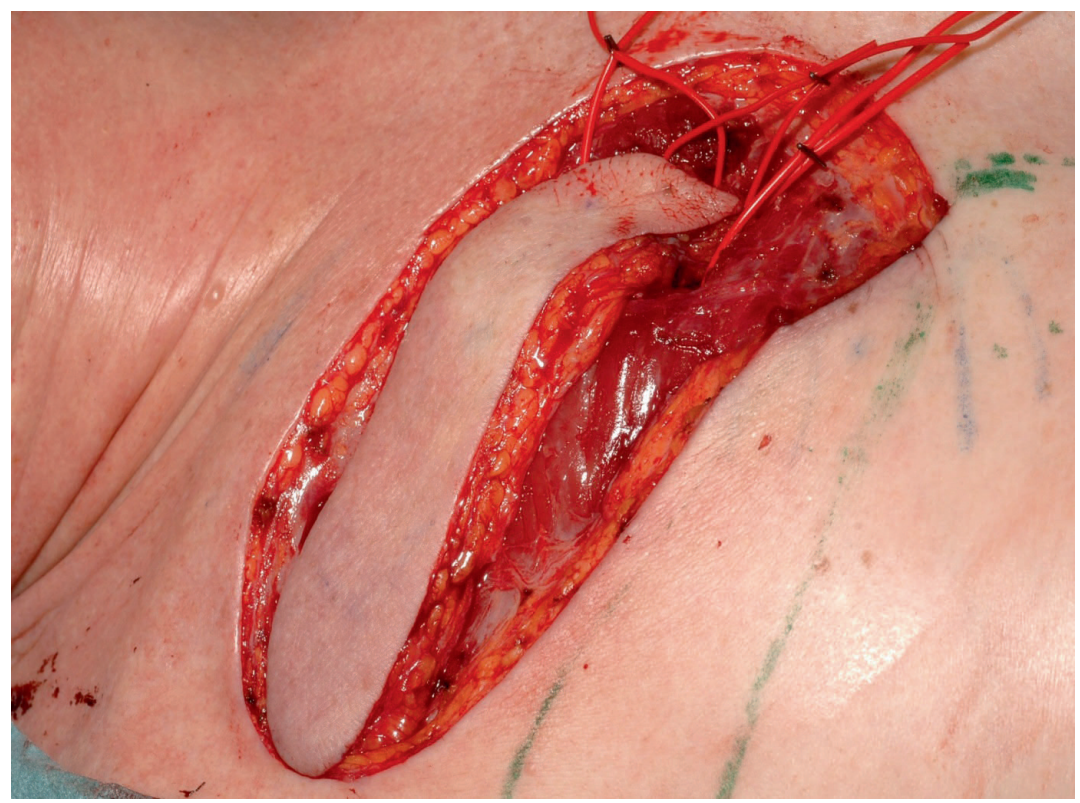

IMAP flap before transfer. 


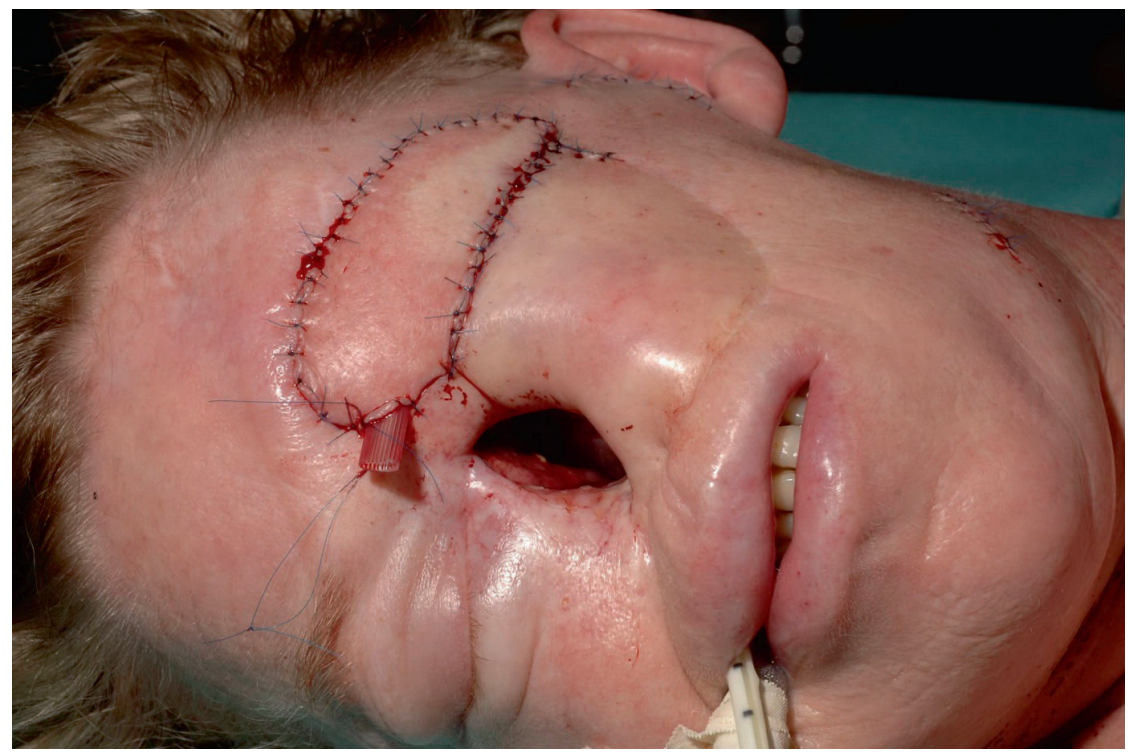

Insetting of flap, arterial anastomosis to deep inferior epigastric artery of previous TRAM flap. Due to incompetence of deep inferior epigastric vein, venous anastomosis was performed on left facial vein using a greater saphenous vein graft.

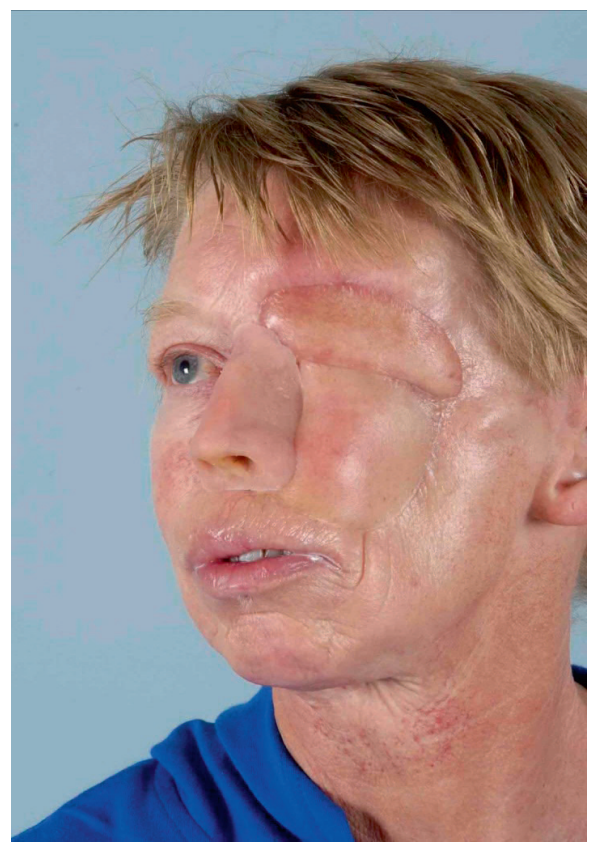

Postoperative result at 8 month. 


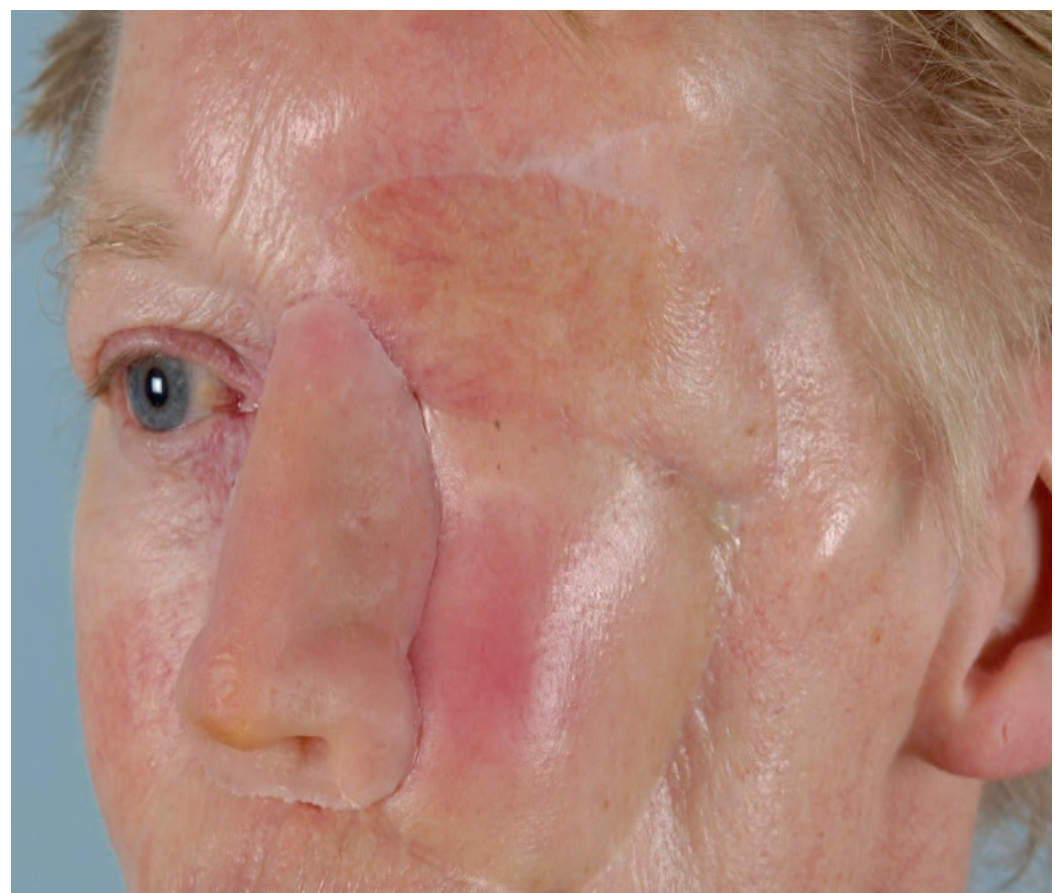

Late post-operative result, no residual infection, excellent colour match.

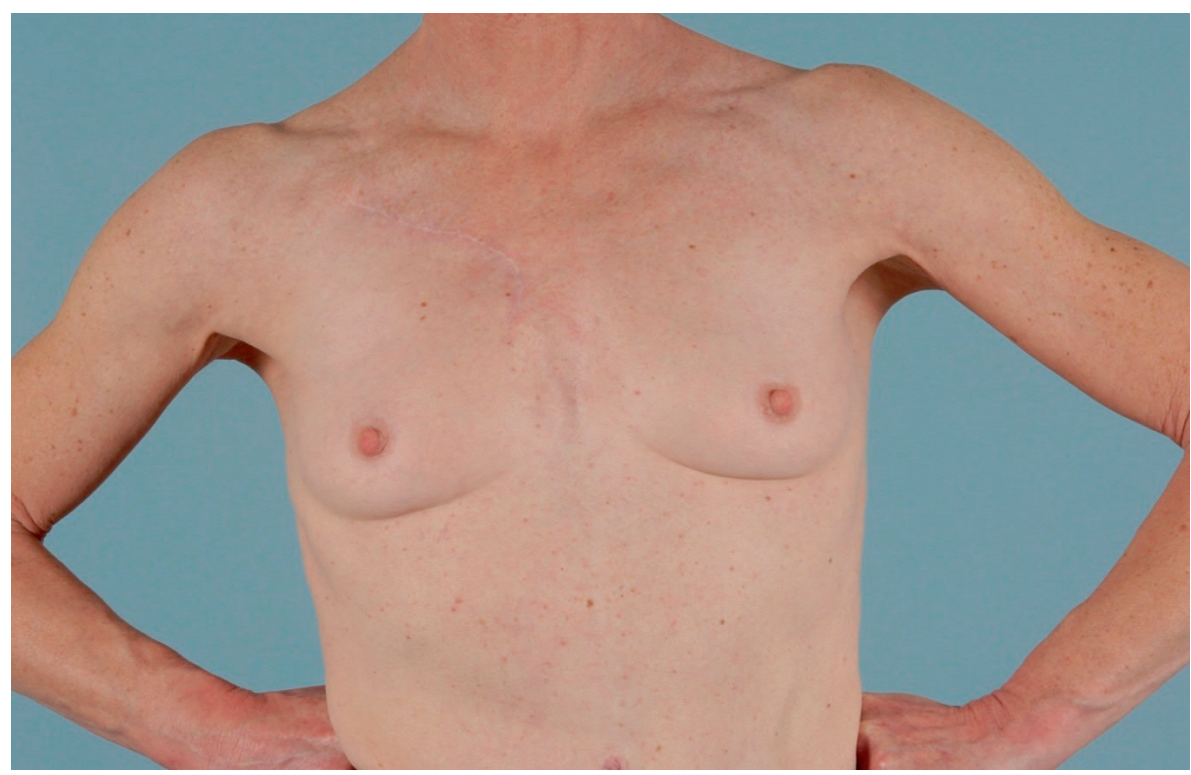

Donor site which good scar quality, no distortion of the breast. 


\section{Case 2}

Radical parotidectomy including the cartilage part of the outer auditory canal and lymph node dissection was performed in a 59-year-old man presenting with a $7 \times 5$ $\mathrm{cm}$ epithelial myo-epithelial carcinoma of his left infra-auricular area. Although we had preoperatively planned to reconstruct the defect with a submental flap, the tumor resection left us with a severed facial artery and no available submental pedicle. The facial nerves, however, had been spared. A $10 \times 6 \mathrm{~cm}$, oval flap based on the second IMAP was dissected over the right second intercostal space. The vascular pedicle could be enhanced up to $5.5 \mathrm{~cm}$ by inclusion of an extra $3 \mathrm{~cm}$ of the internal mammary artery and vein after resection of all cartilage of the second rib and the superior part of the third rib cartilage, and was easily anastomosed end-to-end to the stump of the left facial artery and end-to-side to the left internal jugular vein. The flap healed uneventful and adjuvant radiotherapy was planned but the patient refused further treatment. Eighteen months after surgery, the patient was terminally ill.

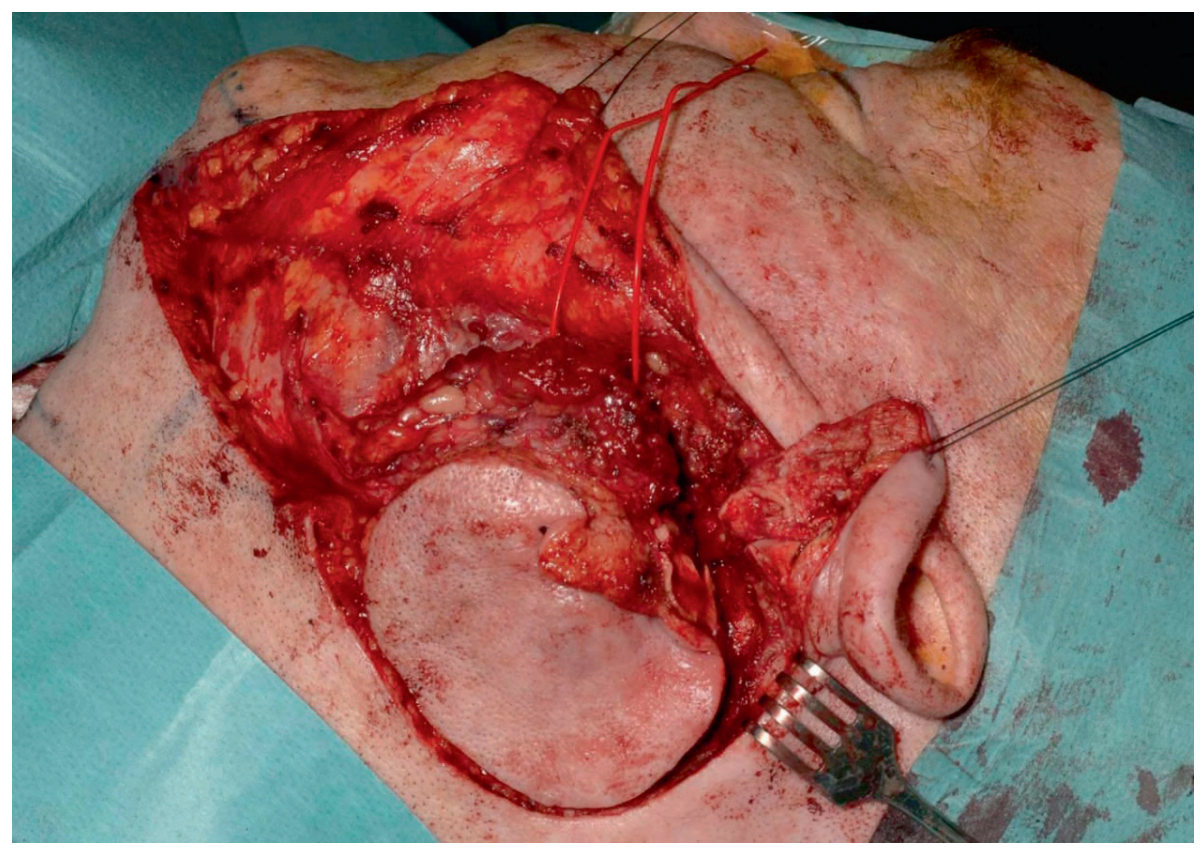




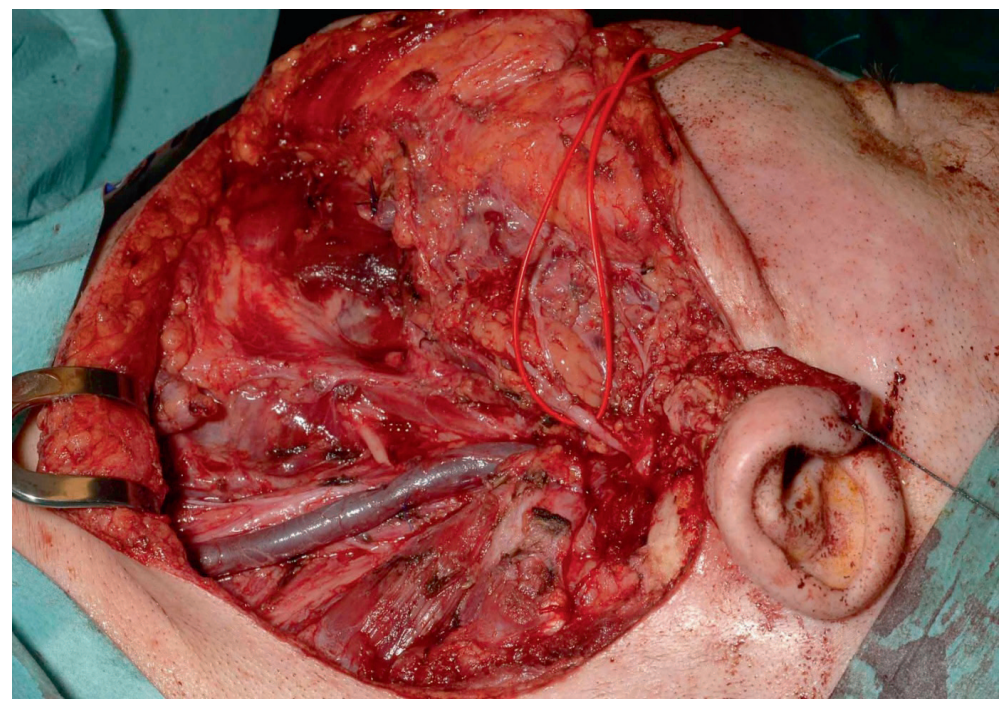

Defect after tumor removal, parotidectomy and lymph node dissection.

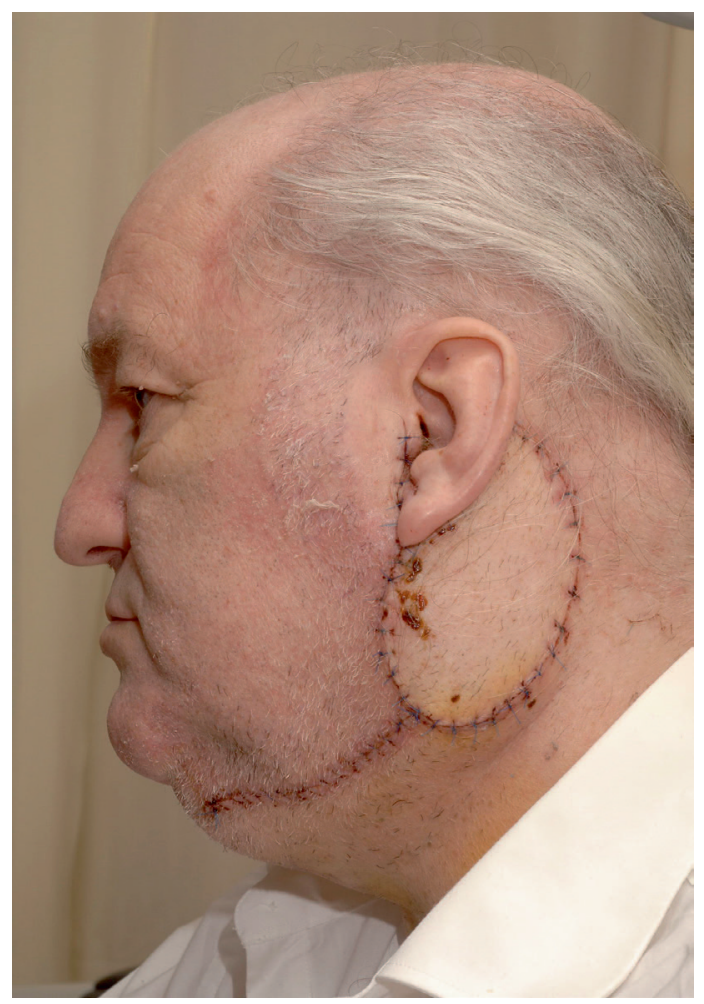

Result after free IMAP transfer on day 5 postoperative. 


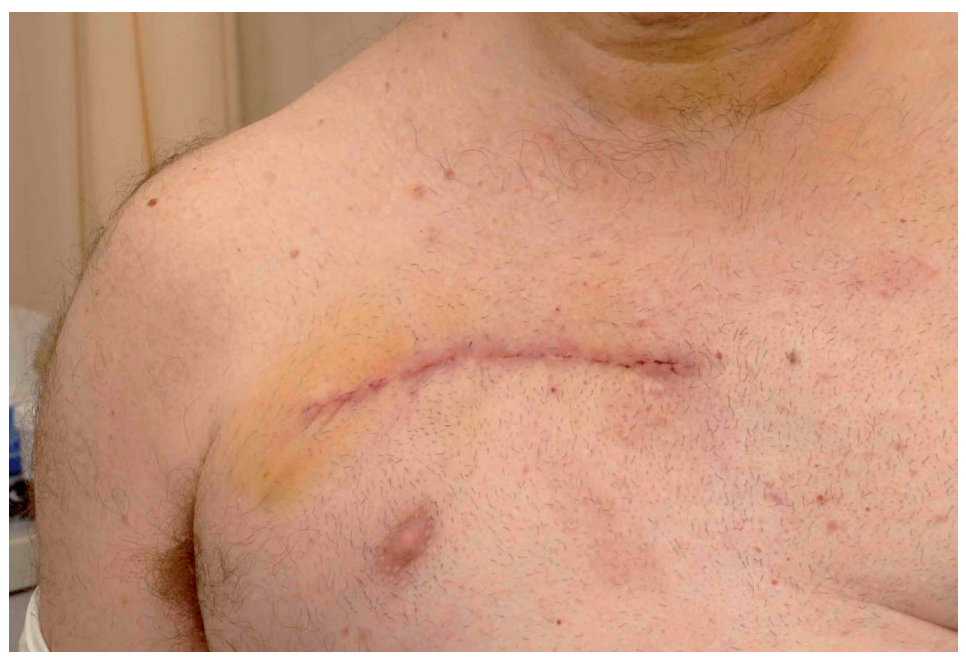

Primary closure of donor defect.

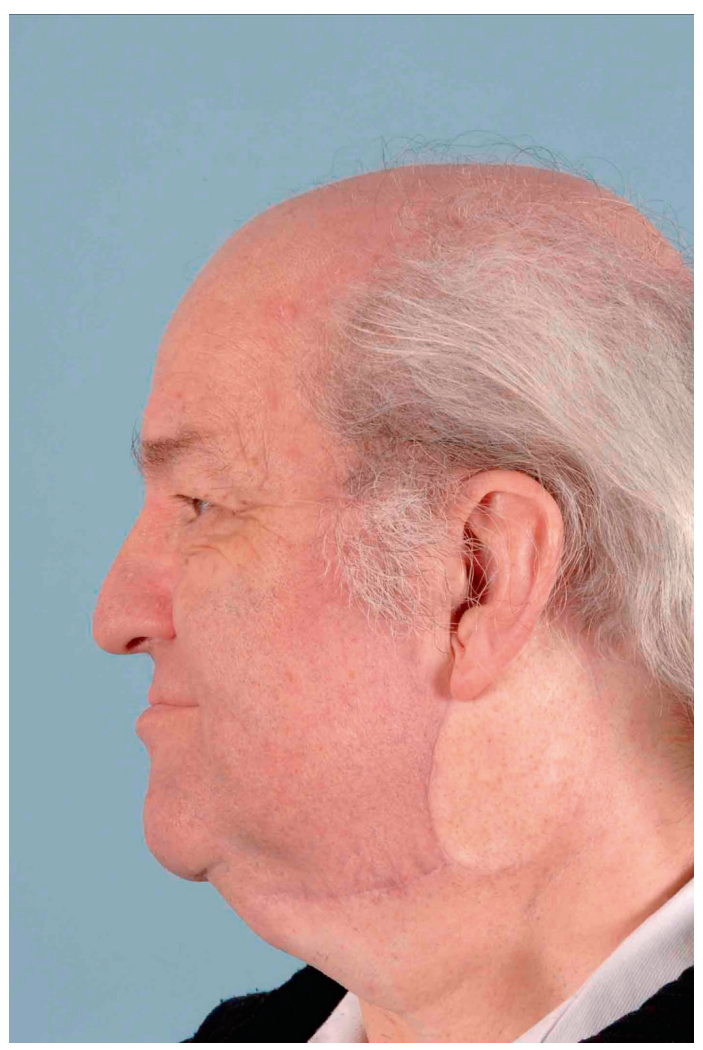

Late postoperative result. Patient refused full radiation treatment. 


\section{Case 3}

A 63-year-old man underwent an ear amputation, subtotal petrosectomy, superficial parotidectomy and lymph node dissection for a deeply invading squamous cell carcinoma of his right auditory canal. Because of the neck dissection, use of a submental or supraclavicular flap was no longer judged a safe option. Hence, the defect was closed using a $7 \times 5 \mathrm{~cm}$ free perforator flap based on the right second IMAP that was enhanced up to $4.5 \mathrm{~cm}$ by resection of the cartilage of the second rib. The internal mammary artery and vein were subsequently anastomosed end-to-end to the external carotid artery and end-to-side to the internal jugular vein, respectively. Histopathologically, the moderately differentiated squamous cell carcinoma was found to infiltrate the mastoid and the deep end of the external auditory canal. The postoperative course was uneventful and the flap sustained adjuvant radiotherapy well. Follow-up currently amounts to 30 thirthy months.

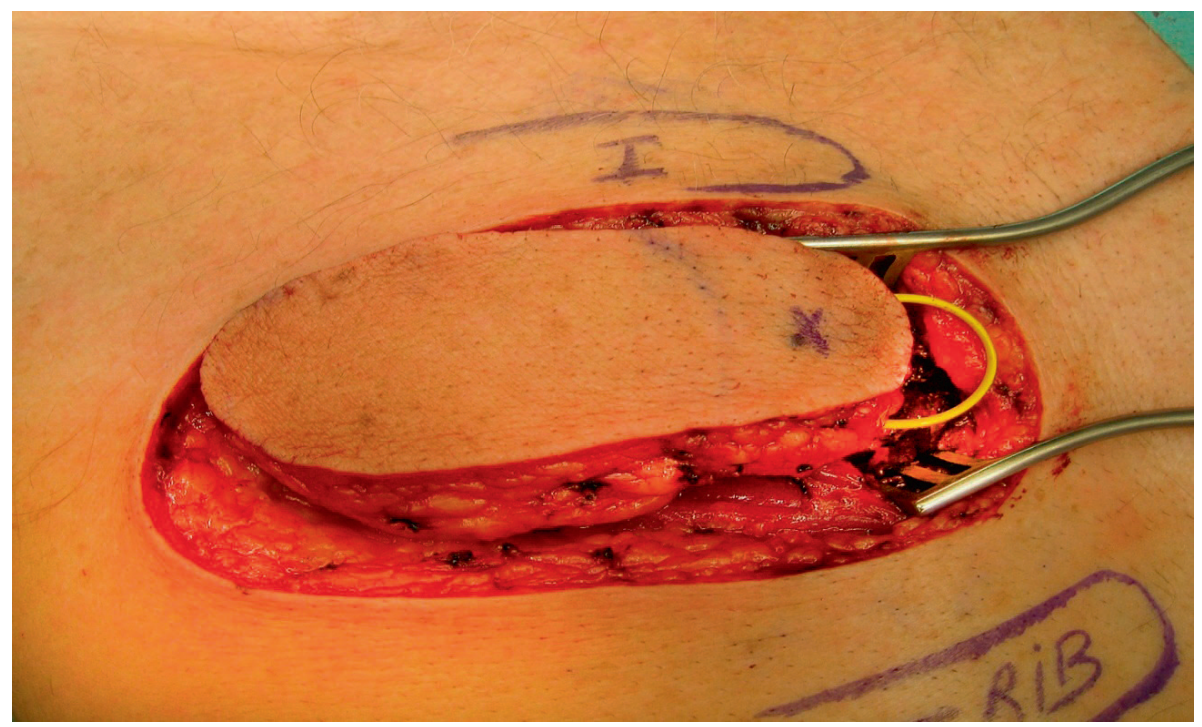

IMAP flap based on second internal mammary artery perforator. 


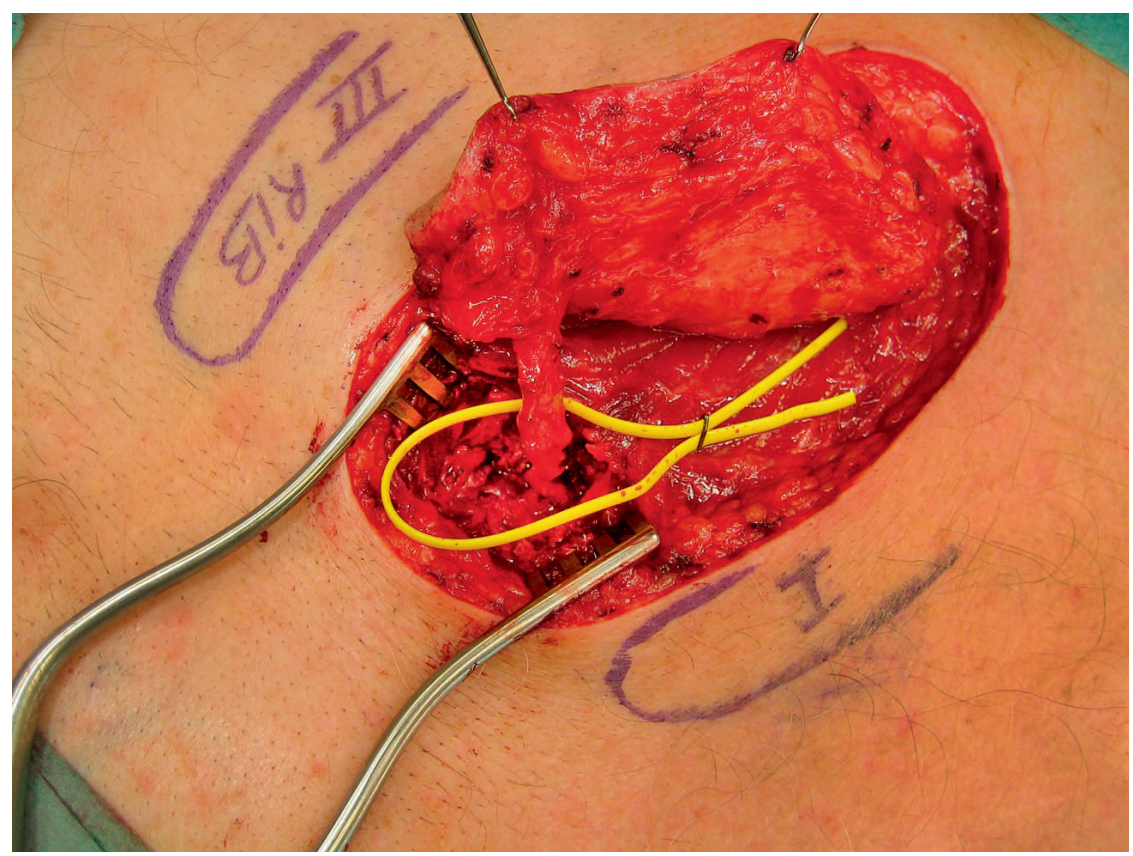

Pedicle enhancement by resection of the cartilage of the second rib.

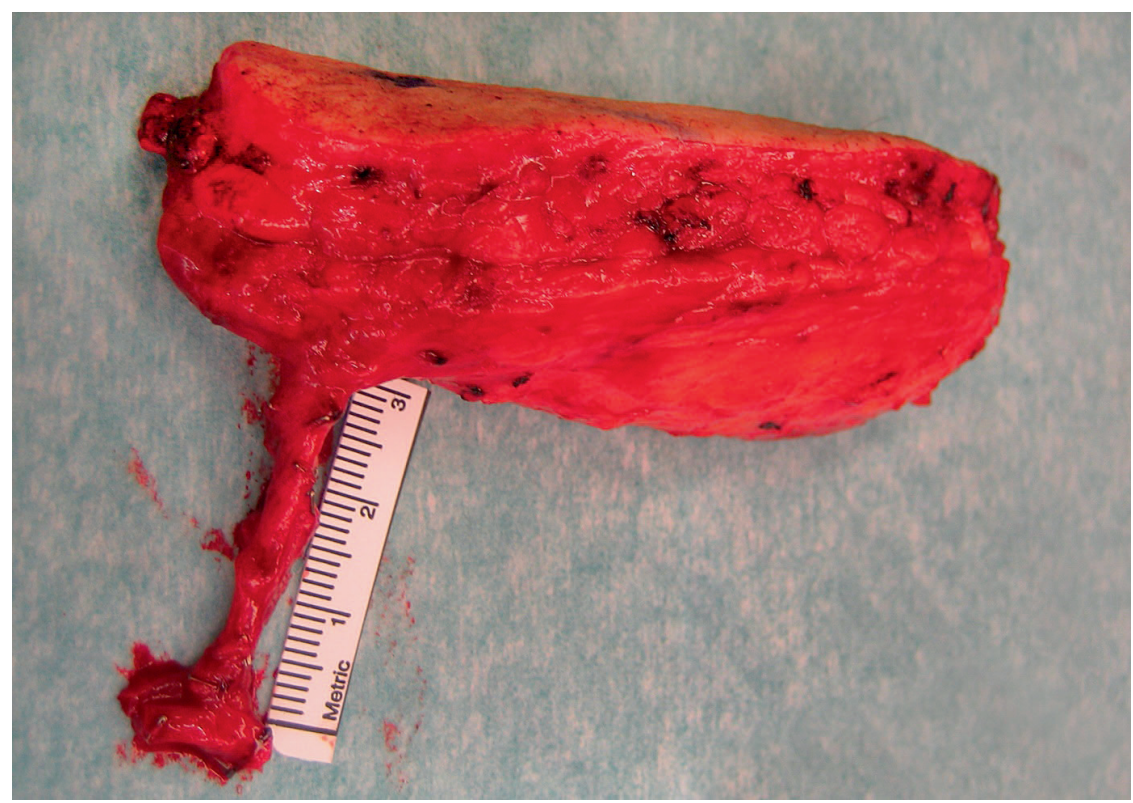

Free IMAP flap, perforator with small part of internal mammary vessels. 


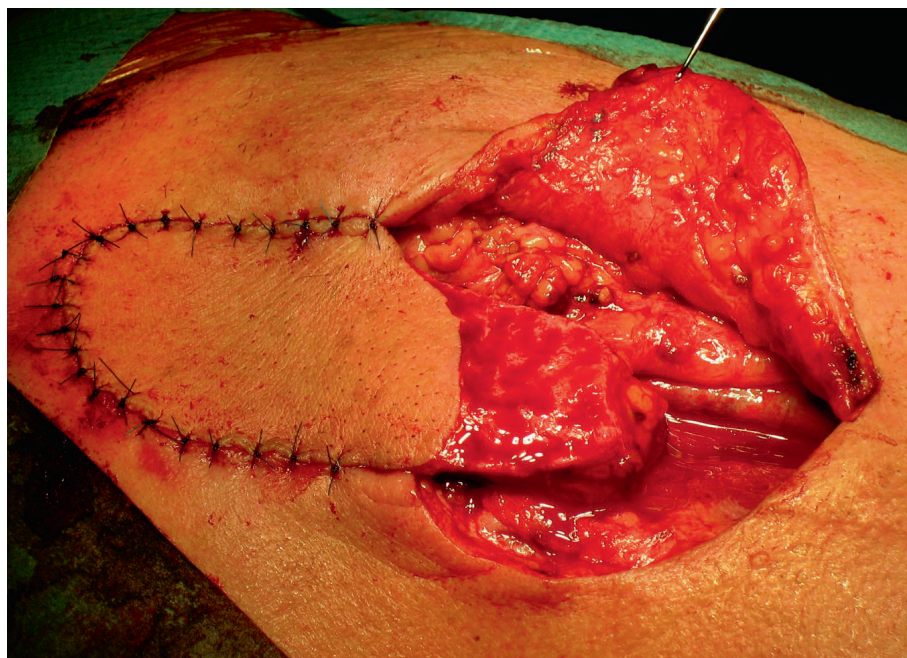

Revascularised IMAP flap, arterial anastomosis to the external carotic artery, venous anastomosis to the internal jugular vein. Part of IMAP flap is deepithelialized and buried under cheek skin.

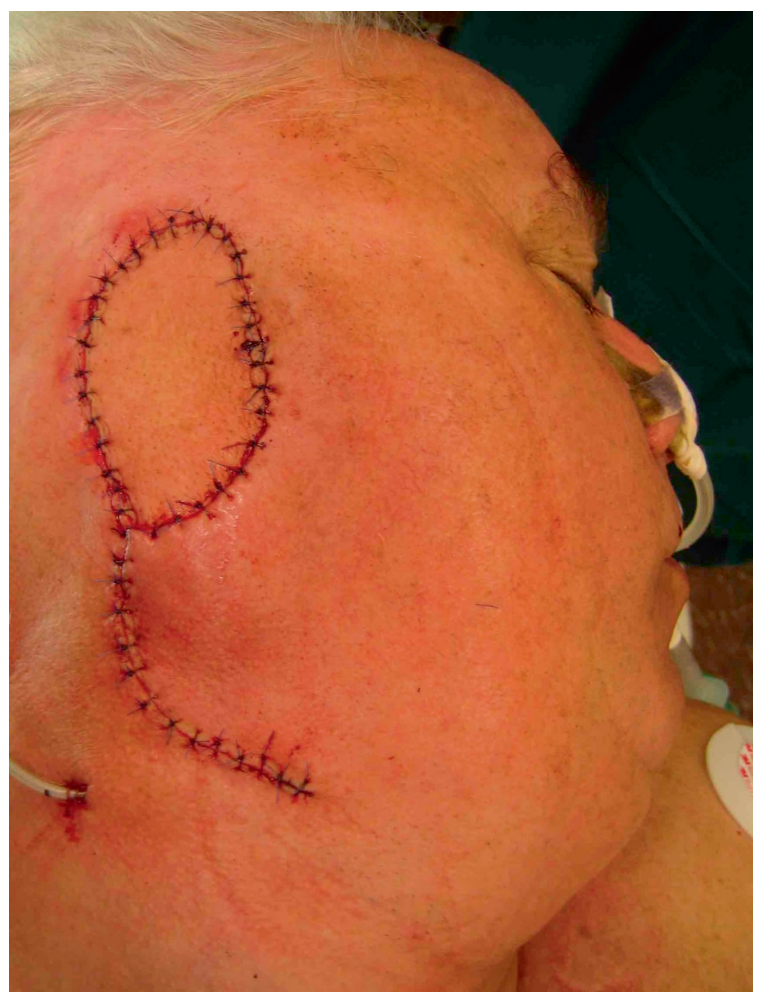

Insetting of revascularised IMAP flap. 


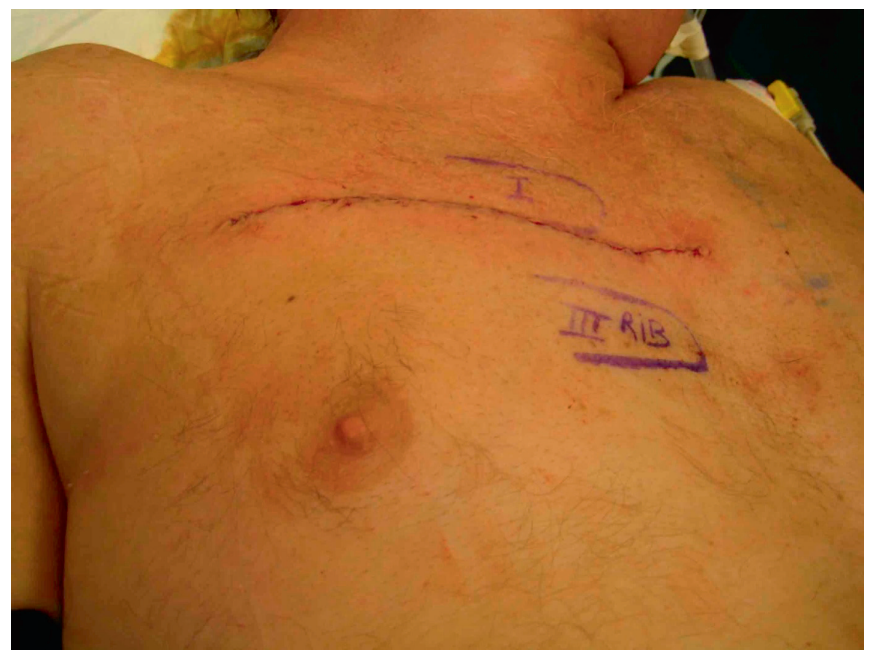

Primary closure of donor site.

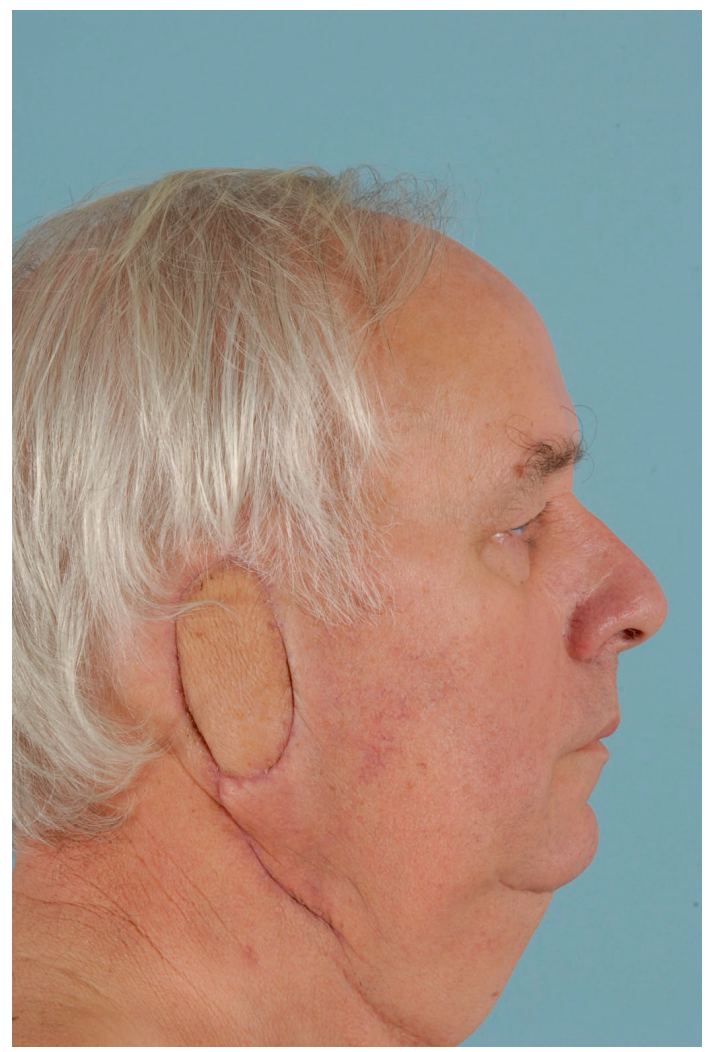

Final result after adjuvant radiotherapy. 


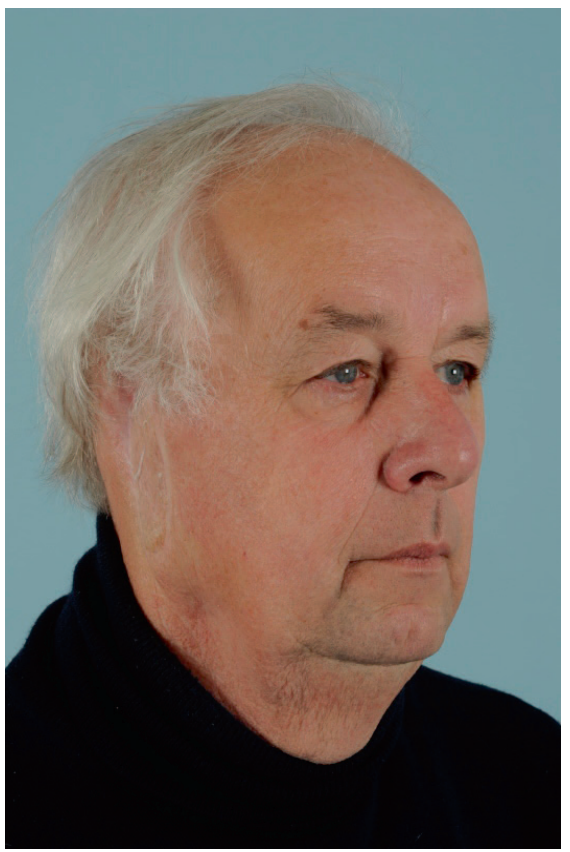

Result 30 months postoperative.

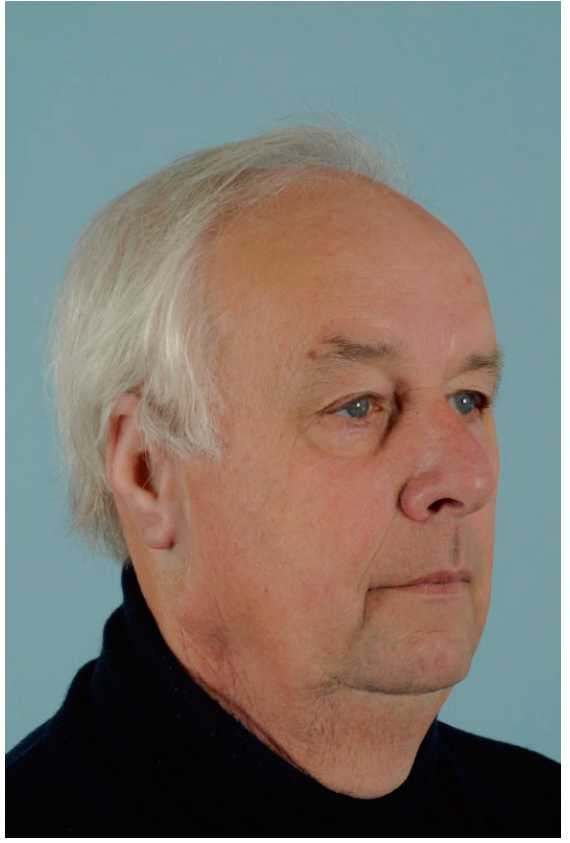

Result with external ear prosthesis. 


\section{Chapter 6}

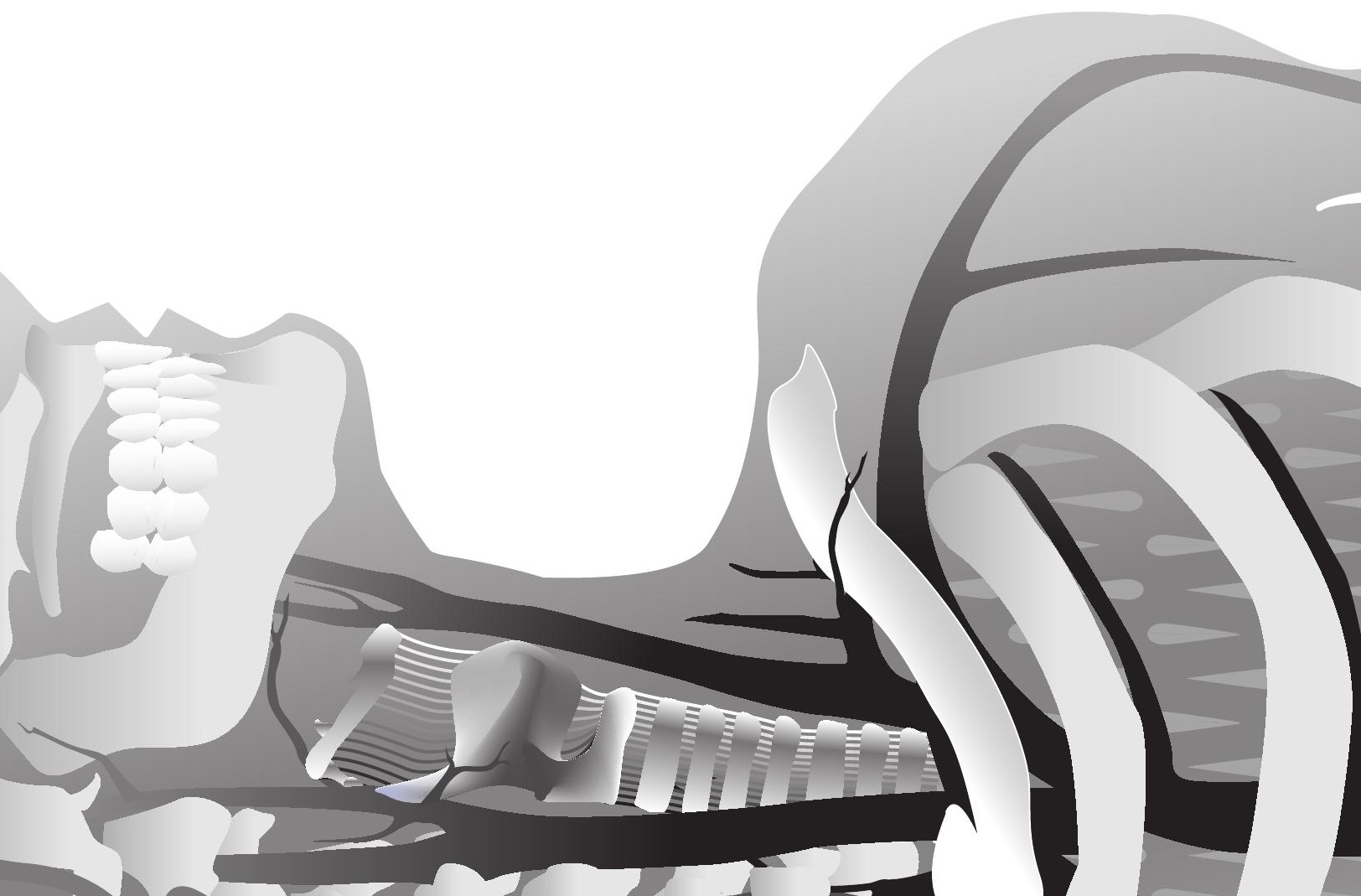


Can previous diagnostic examinations prevent preoperative angiographic assessment of the internal mammary perforators for (micro)surgical use?

Pascal P.A. Schellekens

Tjeerd S. Aukema

J. Joris Hage

Warner Prevoo

Moshe Kon

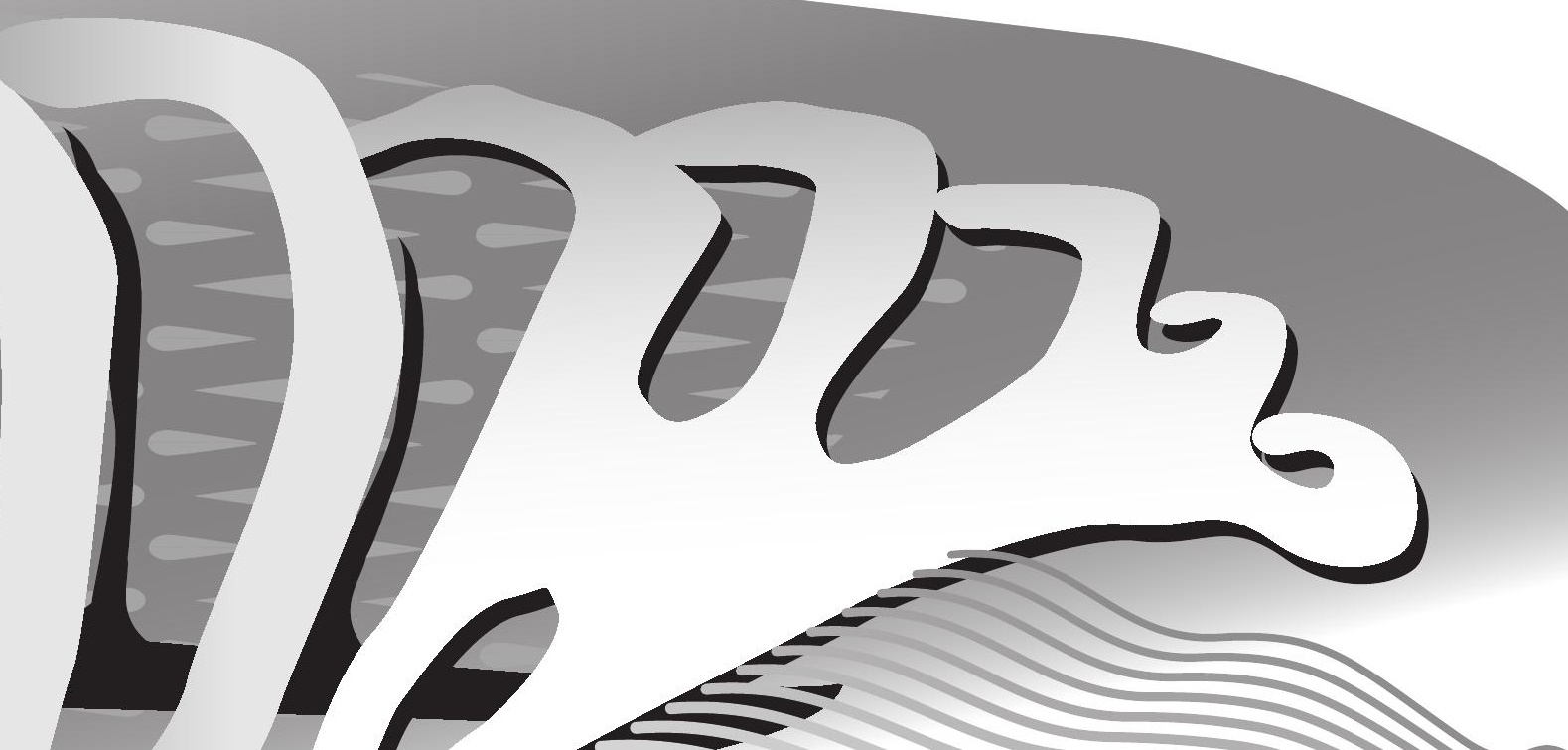




\section{Abstract}

\section{Background and Aim}

Preoperative assessment of the internal mammary artery perforating (IMAP) branches enhances IMAP-based reconstructive procedures. Conventionally, color-flow Doppler, selective catheter arteriography, or CT-angiography is used for such assessment. We studied how often these examinations may be rendered superfluous by assessment of previously performed, diagnostic examinations.

\section{Methods}

A radiologist and a plastic surgeon jointly assessed whether information on the dominant IMAP could sufficiently be obtained from the thoracic CT-scans of 12 head and neck cancer patients and 12 breast cancer patients, and from the mammary MRI of 12 breast cancer patients. Secondly, we retrospectively assessed in how many of the ten patients who underwent an IMAP-flap head and neck reconstruction, and in how many of ten women who consecutively underwent a DIEP flap mammary reconstruction such previous diagnostic examinations were available and informative regarding the level of the dominant perforator.

\section{Results}

All 24 CT-scans and 11 of the $12 \mathrm{MRI}$-scans sufficiently allowed assessment of the level of the dominant IMAP. Previous information had already been available in all ten DIEPflap patients and six of the ten IMAP-flap patients. The distribution of IMAP dominance over the intercostal levels on the scans differed from that found by cadaveric or intraoperative assessment.

\section{Conclusions:}

Previously performed diagnostic CT-scans and MRI-scans that included the parasternal region usually allow sufficient preoperative assessment of the internal mammary perforators for reconstructive procedures. We advocate re-assessment of such previous examinations before ordering additional angiography. Additionally, we suggest to include the parasternal region in diagnostic scans. 


\section{Introduction}

The internal mammary artery usually arises from the lower aspect of the first part of the subclavian artery. It passes downward, forward, and medially, behind the sternocleidomastoid muscle, the clavicle, and the subclavian and internal jugular veins. Joined by the internal mammary vein, it passes further downward behind the upper six costal cartilages and the intervening internal intercostal muscles, just lateral to the sternum. It ends at the sixth intercostal space by dividing into its terminal branches, the superior epigastric and musculophrenic arteries.' A cutaneous perforating branch of both the internal mammary artery and vein passes through the intercostal and pectoralis major muscles to supply the overlying skin in a segmental manner. ${ }^{2,3}$ This internal mammary artery perforator (IMAP) is given off in each of the upper five or six intercostal spaces. ${ }^{1,2}$ The perforator pedicle usually consists of one artery and one vein, with an accompanying nerve, the anterior cutaneous branch of the corresponding intercostal nerve. ${ }^{2,4}$

Over the last decade, these perforating pedicles have gained the interest of reconstructive surgeons as recipient vessels for free tissue transfer for breast surgery. ${ }^{5-11}$ The perforators represent an attractive alternative to the internal mammary artery and vein proper as costal cartilage resection, iatrogenic pneumothorax, and sacrifice of the internal mammary artery for possible future coronary bypass surgery may be avoided. Furthermore, dissection is facilitated and both the operating time and postoperative morbidity can be reduced when the perforating vessels, rather than the internal mammary vessels, are used as recipient vessels. ${ }^{11}$

Likewise, the use of pedicled, ${ }^{2,11-17}$ supercharged, ${ }^{18,19}$ and free flaps ${ }^{20}$ based on the internal mammary perforating vessels have increasingly been reported over the last 5 years. These IMAP flaps share their vascular pedicle with deltopectoral pedicled or free flap s ${ }^{21-23}$ but differ from the deltopectoral flaps in their parasternal or paracostal, ${ }^{15}$ rather than paraclavicular, orientation and their extension up to the anterior axillary line. ${ }^{13,17}$

The intercostal level of the dominant IMAP is variable and depending on chest side, ${ }^{2}$ with 5 to $25 \%$ of the dominant perforators reportedly located in the first, 40 to $69 \%$ in the second, and 10 to $53 \%$ in the third intercostal space (Table 1).1,3, 10,24-26 Furthermore, an IMAP may suffice as recipient vascular pedicle in only 9 to $39 \%$ of women who undergo free flap breast reconstruction. ${ }^{8-10,25,27}$ Consequently, reliable preoperative information on the location, suitability, and size of the dominant internal mammary perforating pedicle would further facilitate the planning and execution of the surgical procedure and may avoid disappointing, costly, and time consuming complications. ${ }^{28}$ 
Such preoperative assessment of the internal mammary vascular system may be performed by laser-Doppler flowmetry, ${ }^{24}$ intra-luminal arteriography, ${ }^{28,}{ }^{29}$ CTangiography, ${ }^{30,31}$ or MR-angiography. Still, IMAP-based reconstructive procedures are often performed in oncological patients who have already undergone extensive diagnostic work-up that included imaging of the thorax or mammary region. Hence, we hypothesized that the internal mammary perforators may well have already been depicted on such diagnostic images. Therefore, we set out to assess whether, or not, these previous examinations allow sufficient preoperative assessment of the level of dominance of the internal mammary perforators that may be used as recipient or donor pedicle for reconstructive procedures.

\section{Materials and methods}

For this study, we selected three categories of patients who undergo radiographic examinations that are routinely performed in the National Cancer Institute: 1- highdose diagnostic thoracic CT-scans made for dissimination assessment in head and neck oncologic patients; 2 - the same pre-operative scans made in women with breast cancer; and 3- pre-mastectomy diagnostic mammary MRI-scans of women with breast cancer or ductal carcinoma in situ. In each category, the radiographic examination of 12 patients were randomly picked for inclusion to assess whether, or not, they were informative regarding the level of the dominant perforator.

Secondly, we retrospectively assessed in how many of the ten patients who underwent an IMAP-flap head and neck reconstruction in the Univerity Medical Center Utrecht, ${ }^{17,20}$ and in how many of ten women who consecutively underwent a DIEP flap mammary reconstruction in the National Cancer Institute, such previous diagnostic examinations were available and informative regarding the level of the dominant perforator.

\section{High-dose thoracic CT-scans made for dissimination assessment}

All 24 patients included in these two categories had undergone routine contrastenhanced thoracic multislice-CT (Somatom, Siemens Medical Systems, Erlangen, Germany). Omnipaque 300 (GE Health Care, Oslo, Norway) containing 300 mg of iodine per milliliter was intravenously administered (dosage: weight of the patient in kilogram minus 10 in milliliters). After acquisition, the slices were reconstructed with separate mediastinal and lung algorithms to transversal $5 \mathrm{~mm}$, and $1 \mathrm{~mm}$ slices. The $1 \mathrm{~mm}$ slices were used for coronal and sagittal reconstructions but the assessment of the IMAP was performed on the transversal $1 \mathrm{~mm}$ slices. 

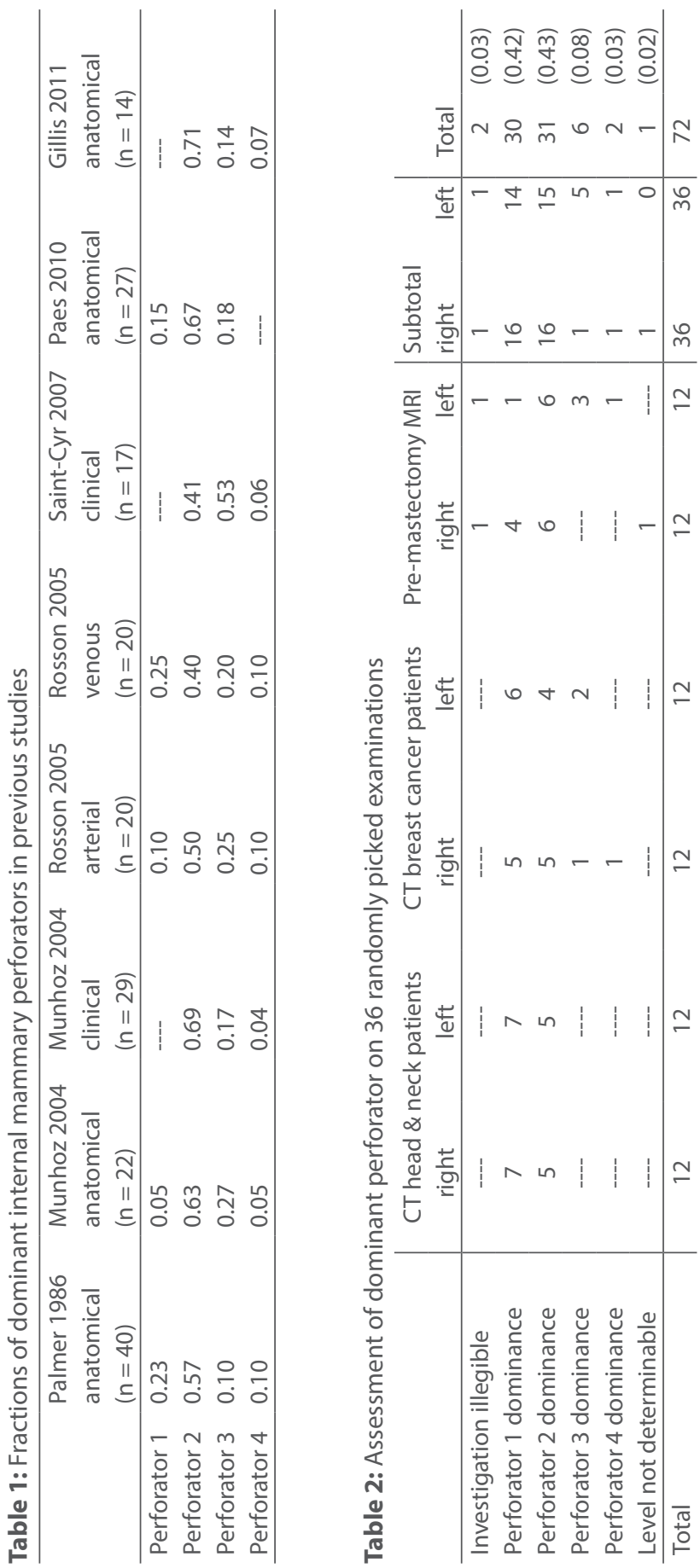


\section{Pre-mastectomy diagnostic mammary MRI-scans}

Magnetic resonance imaging had been performed in the third category of 12 patients with a 1.5-tesla scanner (Magnetom, Siemens Medical Systems, Erlangen, Germany) using a coronal FLASH-3D technique. Both breasts were imaged in prone orientation, using a dedicated double-breast array coil. One series was acquired before the injection of contrast agent, and four series were acquired after a bolus of contrast agent (Prohance, Bracco-Byk Gulden, Konstanz, Germany); $0.1 \mathrm{mmol} / \mathrm{kg}$ body weight, injected intravenously at a rate of $2-4 \mathrm{ml} / \mathrm{s}$ by a power injector (Spectris injection system, Medrad, Warrendale, PA, USA). The series were acquired at intervals of approximately $120 \mathrm{~s}$. The following MRI parameters were used: 3D coronal T1-weighted sequence, repetition time $8.1 \mathrm{~ms}$, echo time $4.0 \mathrm{~ms}$, isotropic voxels of $1.35 \times 1.35 \times 1.35 \mathrm{~mm}^{3}$ and no fat suppression. Subtraction images were available to examine initial and late enhancement.

\section{Pre-operative scans of IMAP- and DIEP-flap patients}

Of the ten patients who underwent an IMAP-flap head and neck reconstruction, as well as of the ten patients who consecutively underwent a DIEP flap mammary reconstruction, all previously performed diagnostic CT- or MRI-scans of the lungs, anterior thorax, or breasts were included for assessment.

\section{Assessment of images and statistical evaluation}

All 36 images of the randomly picked examinations and all available pre-operative CT- or MRI-scans of the IMAP- and DIEP-flap patients were jointly assessed for the information they provided on the parasternal perforating branches of the internal mammary vessels by a radiologist (WP) and a reconstructive plastic surgeon (JJH) by use of a PACS Workstations (Kodak Carestream, Rochester, NY, USA). Legibility of the level of the dominant perforator was used as an indicator of suitability of the image to render additional angiography superfluous. The level of dominance was determined by counting the ribs from the first one down. In case of doubt, the sternal angle was used as landmark for the level of the second rib. The results of this assessment are presented by descriptive statistics. 


\section{Results}

All 24 high-dose thoracic CT-scans of the 7 male and 5 females head and neck patients (age $63 \pm 14.5$ years) and the 12 female breast cancer patients (age $57 \pm 11.8$ years) sufficiently allowed assessment of the internal mammary vascular system to bilaterally indicate the level of the dominant IMAP (Figure 1; Table 2). This was also possible on premastectomy diagnostic mammary MRI-scans (Figure 2) of 11 of 12 additional women (age $51 \pm 11.4$ years). The remaining MRI-scan did not offer sufficient information because its field of view did not include enough of the sternal angle and ribs to allow assessment of the level of the perforators (Figure 3). On the 35 scans that were legible, the dominant IMAP was most often observed at the first and second intercostal level, and less often in the third or fourth intercostal space (Table 2).

In retrospect, we found that sufficient information on the IMAP had been available on at least one of the pre-operative radiological images of six of the ten IMAP-flap patients (age $57 \pm 11.7$ years) operated upon over the last 2 years (Table 3 ), and on those of eight of the ten DIEP patients (age $44 \pm 7.9$ years) (Table 4). Again, an insufficient field of view hampered adequate assessment of the remaining images. In both these groups, the dominant IMAP was mostly observed at the first and second intercostal level (Tables 3 and 4).

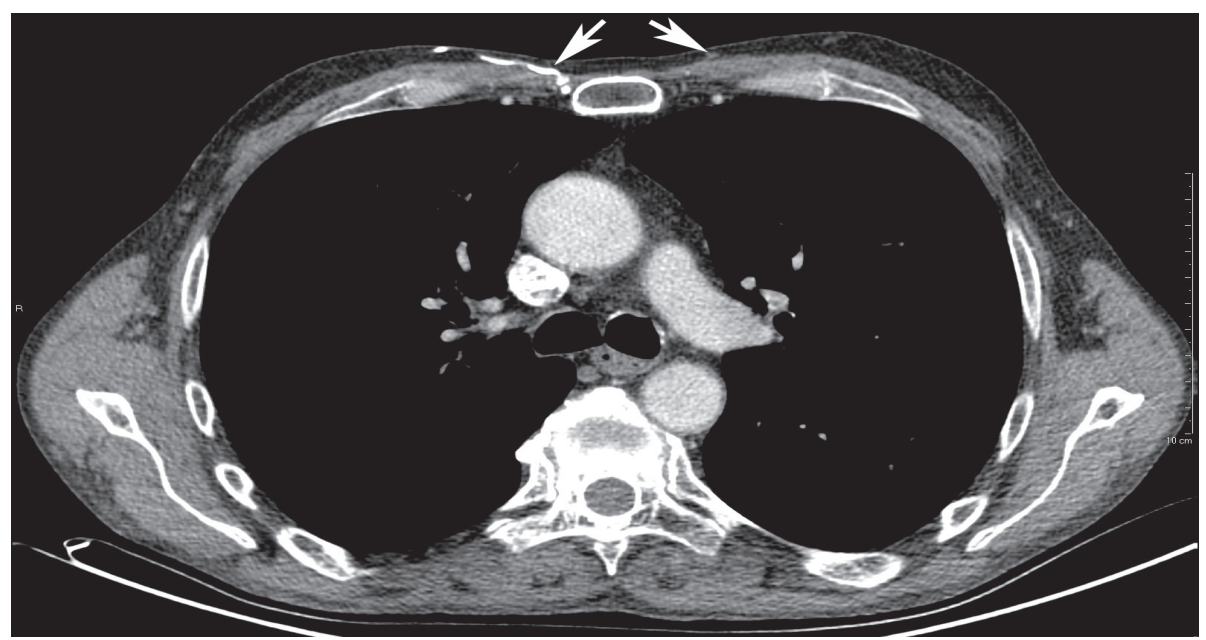

Figure 1: Example of a high-dose diagnostic CT scan that was previously made for dissimination assessment of the longs in a 57-year-old male head and neck oncologic patient with a squamous cell carcinoma of the tongue. The level of both dominant internal mammary perforators could well be determined. On this slide, the right dominant artery (arrow) and part of the left dominant vein (arrow) at the second intercostal level can be seen. 


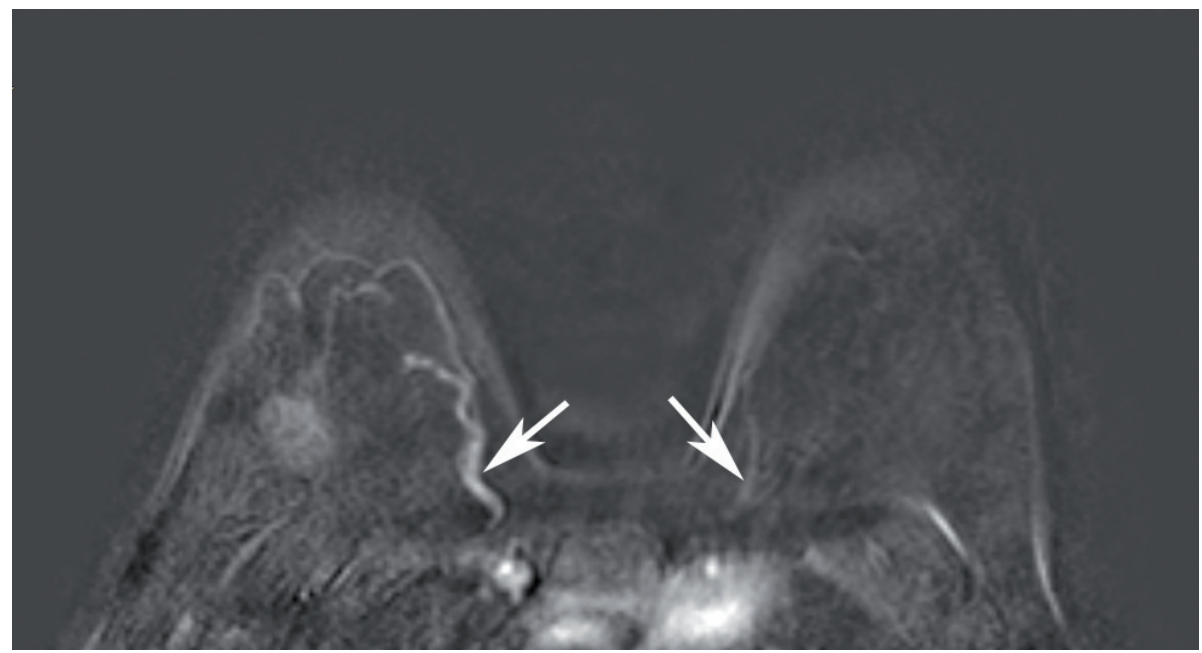

Figure 2: Example of a diagnostic MRI scan that was previously made for the assessment of the breast of a 47-year-old female breast cancer patient. The level of both dominant internal mammary perforators could well be determined on both sides (arrows) as the field of view included the sternal angle.

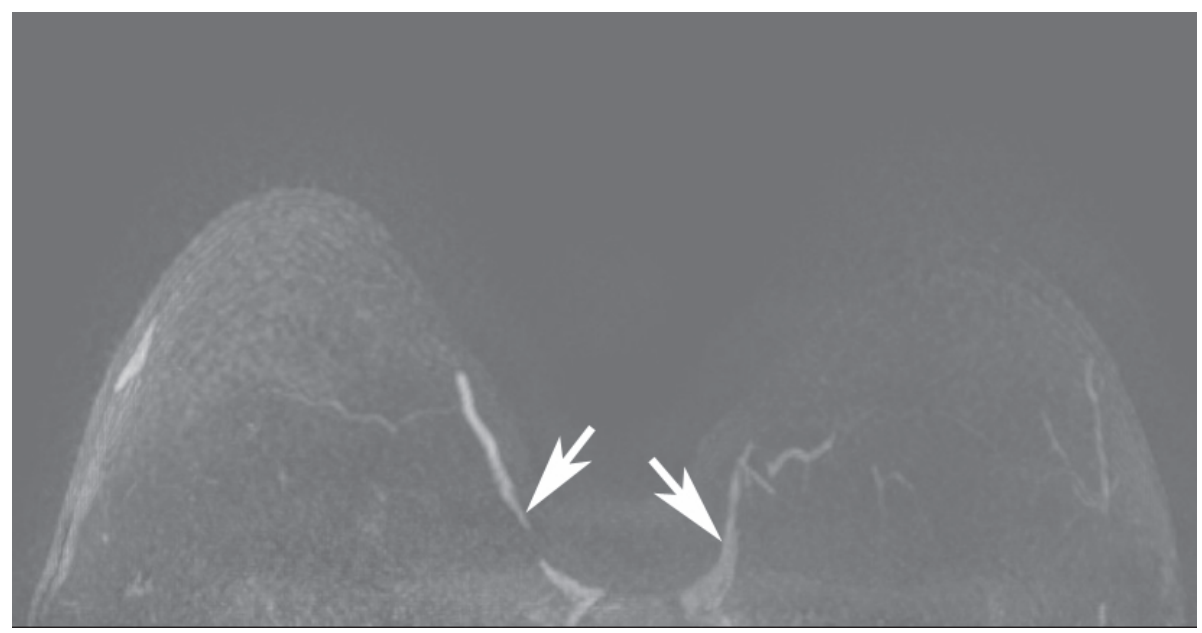

Figure 3: Example of a diagnostic MRI scan that was previously made for the assessment of the mammae of a 47-year-old female breast cancer patient. Although the dominant artery of the right side and the dominant vein of the left side could well be recognized on this slide (arrows), their level could not be determined because of an inadequate field of view that did not include the sternal angle. 
Table 3: Assessment of pre-operative examinations for the dominant perforator in the ten patients in whom we performed an IMAP flap ${ }^{17,20}$

\begin{tabular}{|c|c|c|c|c|c|c|}
\hline $\begin{array}{l}\text { Patient's } \\
\text { age \& sex }\end{array}$ & Diagnosist & $\begin{array}{l}\text { Number of } \\
\text { pre-op } \\
\text { examinations* }\end{array}$ & $\begin{array}{l}\text { Level of } \\
\text { dominant } \\
\text { IMAP right }\end{array}$ & $\begin{array}{l}\text { IMAP } \\
\text { flap } \\
\text { left }\end{array}$ & Pedicled or & free flap \\
\hline 62, male & presternal SCC & 4 & 1 & 1 & left, 2 & pedicled \\
\hline 45, male & clavicular DFSP & 1 & 2 & 3 & left, 2,3 & pedicled \\
\hline 63, male & SCC neck metastasis & 1 & 2 & 1 & left, 2,4 & pedicled \\
\hline 59, male & infra-auricular EM-EC & 0 & ---- & --- & right, 2 & free \\
\hline 30, female & presternal DFSP & 2 & 1 & 2 & left, 7 & pedicled \\
\hline 62, male & SCC neck metastasis & 2 & 2 & 2 & left, 2,3 & pedicled \\
\hline 69, male & SCC neck metastasis & 0 & --- & --- & left, 1,3 & pedicled \\
\hline 54, female & frontal osteomyelitis & 0 & ---- & ---- & right, 2 & free \\
\hline 63, male & auditory canal SCC & 0 & ---- & ---- & right 2 & free \\
\hline 66, male & tracheostomy defect & 1 & 4 & 1 & right, 2 & pedicled \\
\hline
\end{tabular}

†: SCC: squamous cell carcinoma; DFSP: dermatofibrosarcoma protuberans; EM-EC: epithelial myo-epithelial carcinoma

*: number of pre-operative radiological examinations that could have been informative regarding the internal mammary perforator vessels

Table 4: Assessment of pre-operative examinations for the dominant perforator in the ten women in whom we performed a DIEP flap

\begin{tabular}{llll}
\hline $\begin{array}{l}\text { Patient's } \\
\text { age }\end{array}$ & $\begin{array}{l}\text { Type of pre-op } \\
\text { examination }\end{array}$ & $\begin{array}{l}\text { Level of dominant IMAP } \\
\text { right }\end{array}$ & left \\
\hline 35 & MRI breast & nd & nd \\
37 & MRI breast; CT thorax & 3 & 2 \\
59 & MRI breast & 1 & 2 \\
38 & MRI breast & nd & nd \\
45 & Radiotherapy planning CT & 1 & 2 \\
48 & MRI breast & 1 & 2 \\
41 & Radiotherapy planning CT & 1 & 1 \\
39 & MRI breast & 2 & 2 \\
55 & MRI breast & 1 & 1 \\
40 & MRI breast & 2 & 3 \\
\hline
\end{tabular}

nd: non determinable 


\section{Discussion}

In these series of pre-operative radiologic examinations that were not intentionally made for the assessment of the level of the dominant perforators of the internal mammary vascular system, we found this level to still be detectable in $60 \%$ (in the ten actual IMAP patients) to $100 \%$ (in both groups of 12 patients that underwent highdose diagnostic thoracic CT-scans made for dissimination assessment). In other words: additional pre-operative assessment of the level of the dominant perforator can often be prevented by re-assessment of readily available, previous (diagnostic) radiological examinations such as MRI or CT of the breast, thorax, or lungs.

\section{Potential methodological limitations}

Before we discuss our observations, some potential methodological limitations need to be addressed. As such, the number of examined radiological images was limited in each of the categories of patients. Still, we only wanted to assess whether, or not, previous radiological examinations might allow sufficient preoperative assessment of the level of dominance of the internal mammary perforators and found this to be true in the (vast) majorities of our samples. Second, we observed the dominant perforator to be located in the first intercostal space as often as in the second intercostal space To date, all reported series observed the dominance to occur 2 to 13 times more often at the second intercostal level than at the first (Table 1). This difference may be explained by the fact that five of the previous reports were based on cadaveric anatomical dissection and imaging, ${ }^{1,3,10,24,26}$ rather than on the in vivo imaging techniques we assessed. Postmortem changes may have influenced the results of these reports. The remaining two reports were based on the findings in the 29 out of 40 surgical dissections in which the perforating vessels could still be found subcutaneously, ${ }^{10}$ or those in a group of patients in whom it was intraoperatively decided that the perforating vessels were of sufficient caliber and level to be used for the micro-anastomosis. ${ }^{25}$ Both methods may likely have resulted in a selection bias, the more so since the first intercostal level was probably not extensively explored surgically. Furthermore, both studies were executed in women who had previously undergone breast amputation and this may very well have chanced the order of dominance of the internal mammary perforators.

\section{Use of perforators, rather than internal mammary vessels, for micro-anastomoses}

The internal mammary vessels gained popularity for autologous free flap breast reconstruction because they offer suitable vascular diameter after a straightforward dissection, allow easier microsurgical accessibility to both surgeon and assistant, and 
enable more optimal aesthetic shaping of the free flap. ${ }^{32-36}$ This holds true particularly for delayed, secondary breast reconstruction after radiotherapy of the parasternal region. ${ }^{37-40}$ Use of the perforators, rather than the internal mammary vessels proper may, furthermore, reduce dissection time and recipient site morbidity. To date, the IMAPs used for this were predominately located at the second or third intercostal space..$^{8-10,25}$ Rather than agreement on the level of the dominant IMAP, this shows good agreement on the IMAP at the second or third intercostal level as vessels adequate for microvascular anastomosis to free lower abdominal flaps. ${ }^{25}$

Proper planning of an IMAP pedicled or free flap includes preoperative assessment of these perforators, particularly to distinguish the dominant perforator in cases where the flap can be vascularized by one perforator only. Hence, a reliable method of preoperative localization of the dominant IMAP is called for.

\section{Pre-operative assessment of the internal mammary vascular system}

Preoperative assessment of the internal mammary system as recipient vessels help to avoid disappointing, costly, and time consuming procedures and complications. ${ }^{28}$ In case of congenital or acquired absence, occlusion or stricture, a simple microvascular anastomosis may not be feasible. Many women who present for secondary autologous breast reconstruction have undergone parasternal radiotherapy that has been proven to negatively alter the architecture of the internal mammary arteries. ${ }^{40}$ Selective catheter substraction arteriography has long been the gold standard for the preoperative assessment of the internal mammary recipient vascular pedicle in breast reconstruction. It is invasive and unfavorably known for its rates of allergic reactions, vasospasm, vessel damage, hematoma, and infection. ${ }^{41-43}$ Moreover, it does not adequately allow the assessment of the comittant veins, the actual measurement of the vascular diameter, and its distance to the lateral border of the sternum.

Over the last decade, CT-angiography has been popularized for these reasons. ${ }^{30,31,44-46}$ It does not necessitate arterial puncture or day-care admittance and, as a result of increased scan speed and improved spatial resolution, the recently introduced multislice technology may even offer improved quality for angiographic imaging. ${ }^{30,} 31,44-47$ Three-dimensional reconstruction protocols of CT-scans permit the arteries and veins to be viewed from any perspective and allow vascular diameters to be accurately measured. These advantages can be contrasted with limited disadvantages such as the need for larger amounts of contrast medium, the need to optimize the timing of the contrast bolus and the scan, and a fair amount of radiation for the scanning protocol. Lately, MR-angiography has been introduced to limit these disadvantages of the preoperative assessment of vascular pedicles even further. 


\section{Pre-operative assessment of the level of the dominant perforator}

Often, the dominant IMAP is selected pre-operatively on the basis of the strongest signal of a hand-held Doppler auscultatory device. ${ }^{13,48}$ We did so in most of our 10 IMAP flap patient, ${ }^{17,20}$ and found that the interpretation of the Doppler signal was hampered by the vascular rustle of the internal mammary artery along its parasternal course and a firmer subcutaneous fat layer may render the Doppler auscultation less reliable (Table 3). ${ }^{13}$ This may hamper preoperative auscultation of the IMAP, particularly in the female mammary region. Therefore, it is advised to intra-operatively confirm the adequacy of the pre-operative assessment and accurately locate the vessels for the proposed flap through an exploratory incision before circumcising the flap. ${ }^{13}$ Alternatively, repeated sonographic assessment of the degree of perfusion of the dissected perforators may be performed. ${ }^{13,14,17,20}$

For these reasons, pre-operative Duplex sonography or any form of angiography is advised to assess the level of the dominant perforator to be used as a pedicle of the IMAP flap. ${ }^{2,11-13}$ Using a lateral approach with Duplex songraphy, the dominant perforator may easily be recognized as its diameter reportedly is twice as large in $85 \%$ of cases. ${ }^{1}$ Still, only CT- or MR-angiography will allow direct measurement of the vascular diameter and superior 3-dimensional information on the course and caliber of both the artery and veins. ${ }^{44}$ Advances in imaging techniques generally increase, rather than reduce, healthcare expenditures. ${ }^{49}$ In this era of increasing healthcare expenses, physicians are bound to take the costs of each imaging modality into account. The more so, when the results of previous scans may include the purpose of any additional scan.

In this first in vivo imaging study, we have now shown that such information is available on previously made, diagnostic CT- or MR-scans in the majority of our patients. Since its introduction to clinical medicine in 2001, PET/CT is increasingly used as a staging modality in oncological patients worldwide. ${ }^{50}$ Often, high dose CT images are used for this and these equally proved to be of sufficient quality to allow assessment in this study (Figure 1).

In conclusion, we advocate re-assessment of such previous examinations before ordering additional angiography. Moreover, we suggest that the field of view of thoracic or mammary CT- and MRI-scans made for oncologic diagnostic purposes should always include the internal mammary system, sternum and parasternal anatomy to allow proper assessment of the internal mammary perforators. This may render additional pre-operative radiological examinations superfluous, thus preventing additional burden, costs, and delay. 


\section{References}

1. Palmer JH, Taylor GI. The vascular territories of the anterior chest wall. Br J Plast Surg; 39: 287-299, 1986.

2. Vesely MJ, Murray DJ, Novak CB, et al. The internal mammary artery perforator flap: an anatomical study and a case report. Ann Plast Surg; 58: 156-61, 2007.

3. Paes EC, Schellekens PP, Hage JJ, et al. A cadaver study of the vascular territories of dominant and non-dominant internal mammary artery perforators. Ann Plast Surg,67: 68-72, 2011.

4. Schellekens PPA, Paes EC, Hage JJ, et al. Anatomy of the vascular pedicle of the internal mammary artery perforator (IMAP) flap as applied for head and neck reconstruction. J Plast Reconstr Aesthet Surg; 64: 53-57, 2011.

5. Guzzetti T, Thione A. Successful breast reconstruction with a perforator to deep inferior epigastric perforator flap. Ann Plast Surg, 46: 641-643, 2001.

6. Blondeel P. Re: Successful breast reconstruction with a perforator-to-deep inferior epigastric perforator flap. Ann Plast Surg; 48: 214, 2002.

7. Park MC, Lee JH, Chung J, Lee SH. Use of internal mammary vessel perforator as a recipient vessel for free TRAM breast reconstruction. Ann Plast Surg; 50: 132-137, 2003.

8. Haywood RM, Raurell A, Perks AG, et al. Autologous free tissue breast reconstruction using the internal mammary perforators as recipient vessels. Br J Plast Surg; 56: 689-691, 2003.

9. Hamdi M, Blondeel P, Van Landuyt K, Monstrey S. Algorithm in choosing recipient vessels for perforator free flap in breast reconstruction: the role of the internal mammary perforators. $\mathrm{Br} J$ Plast Surg 2004; 57: 258-265, 2004.

10. Munhoz AM, Ishida LH, Montag E, et al. Perforator flap breast reconstruction using internal mammary perforator branches as a recipient site: an anatomical and clinical analysis. Plast Reconstr Surg 114: 62-68, 2004.

11. Schmidt M, Aszmann OC, Beck H, Frey M. The anatomic basis of the internal mammary artery perforator flap: a cadaver study. J Plast Reconstr Aesthet Surg; 63: 191-196, 2010.

12. Morain WD, Hallock GG, Neligan PC. Internal mammary artery perforator flap. In Blondeel PN, Morris SF, Hallock GG, Neligan PC, eds. Perforator Flaps - Anatomy, Technique \& Clinical Applications. St. Louis, Missouri: Quality Medical Publishing, 2006. pp. 429-439.

13. Yu P, Roblin P, Chevray P. Internal mammary artery perforator (IMAP) flap for tracheostoma reconstruction. Head Neck; 28: 723-729, 2006.

14. Neligan PC, Gullane PJ, Vesely M, Murray D. The internal mammary artery perforator flap: new variation on an old theme. Plast Reconstr Surg; 119: 891-893, 2007

15. Iyer NG, Clark JR, Ashford BG. Internal mammary artery perforator flap for head and neck reconstruction. ANZ J Surg; 79: 799-803, 2009

16. Saint-Cyr M, Schaverien M, Rohrich RJ. Preexpanded second intercostal space internal mammary artery pedicle perforator flap: case report and anatomical study. Plast Reconstr Surg 123; 16591664, 2009.

17. Schellekens PP, Hage JJ, Paes EC, Kon M. The internal mammary artery perforator pedicled island flap for reconstruction of the lower head and neck and supraclavicular region: how we do it. Clin Otolaryngol; 35: 332-336, 2011.

18. Hyakusoku H, Gao JH, Pennington DG, et al. The microvascular augmented subdermal vascular network (ma-SVN) flap: its variations and recent development in using intercostal perforators. $\mathrm{Br} J$ Plast Surg; 55: 402-411, 2002.

19. Ogawa R, Hyakusoku H. Bipedicled free super-thin flap harvesting from the anterior chest. Plast Reconstr Surg; 113: 1299-1300, 2004

20. Schellekens PP, Hage JJ, Paes EC, Kon M. Clinical application and outcome of the internal mammary artery perforator (IMAP) free flap for soft tissue reconstructions of the upper head and neck region in three patients. Microsurgery ; 30: 627-631, 2011.

21. Harii K, Omori K, Omori S. Free deltopectoral skin flaps. Br J Plast Surg; 27: 231-239, 1974. 
22. Portnoy WM, Arena S. Deltopectoral island flap. Otolaryngol Head Neck Surg ; 111: 63-69, 1994.

23. Sasaki K, Nozaki M, Honda T, et al. Deltopectoral skin flap as a free skin flap revisited: further refinement in flap design, fabrication, and clinical usage. Plast Reconstr Surg; 107: 1134-1141, 2001.

24. Rosson GD, Holton LH, Silverman RP, et al. Internal mammary perforators: a cadaver study. J Reconstr Microsurg; 21: 239-242, 2005.

25. Saint-Cyr M, Chang DW, Robb GL, Chevray PM. Internal mammary perforator recipient vessels for breast reconstruction using free TRAM, DIEP, and SIEA flaps. Plast Reconstr Surg ; 120: 1769-1773, 2007.

26. Gillis JA, Prasad V, Morris SF. Three-dimensional analysis of the internal mammary artery perforator flap. Plast Reconstr Surg; 128: 419e-426e, 2011.

27. Munhoz AM. Internal mammary perforator recipient vessels for breast reconstruction using free TRAM, DIEP, and SIEA flaps. Plast Reconstr Surg; : 315-316, 2008.

28. Schwabegger $\mathrm{AH}$, Bodner $\mathrm{G}$, Rieger $\mathrm{M}$, et al. Internal mammary vessels as a model for power Doppler imaging of recipient vessels in microsurgery. Plast Reconstr Surg; 104: 1656- 1665, 1999.

29. Hefel L, Schwabegger A, Ninkovic M, et al. Internal mammary vessels: anatomical and clinical considerations. Br J Plast Surg; 48: 527-532, 1995.

30. Klein MB, Karanas YL, Chow LC, et al. Early experience with computed tomographic angiography in microsurgical reconstruction. Plast Reconstr Surg ; 112: 498-503, 2003.

31. Chow LC, Napoli A, Klein MB, et al. Vascular mapping of the leg with multi- detector row CT angiography prior to free-flap transplantation. Radiology; 237: 353-260, 2005.

32. Ninkovic $M$, Anderl $H$, Hefel $L$, et al. Internal mammary vessels: a reliable recipient system for free flaps in breast reconstruction. Br J Plast Surg; 48: 533-539, 1995.

33. Dupin $\mathrm{CL}$, Allen RJ, Glass CA, Bunch $\mathrm{R}$. The internal mammary artery and vein as a recipient site for free-flap breast reconstruction: a report of 110 consecutive cases. Plast Reconstr Surg; 98: 685-689, 1996.

34. Feng LJ. Recipient vessels in free-flap breast reconstruction: a study of the internal mammary and thoracodorsal vessels. Plast Reconstr Surg; 99: 405-416, 1997.

35. Majumder S, Batchelor AG. Internal mammary vessels as recipients for free TRAM breast reconstruction: aesthetic and functional considerations. Br J Plast Surg; 52: 286-289, 1999.

36. Quaba O, Brown A, Stevenson H. Internal mammary vessels, recipient vessels of choice for free tissue breast reconstruction? Br J Plast Surg; 58: 881-882, 2005.

37. Tran NV, Chang DW, Gupta A, et al. Comparison of immediate and delayed free TRAM flap breast reconstruction in patients receiving postmastectomy radiation therapy. Plast Reconstr Surg; 108: 78-82, 2001.

38. Moran SL, Nava G, Behnam AB, Serletti JM. An outcome analysis comparing the thoracodorsal and internal mammary vessels as recipient sites for microvascular breast reconstruction: a prospective study of 100 patients. Plast Reconstr Surg; 111: 1876-1882, 2003.

39. Schulman HE, Korr KS, Myers TJ. Left internal thoracic artery graft occlusion following mediastinal radiation therapy. Chest; 105: 1881-188, 1994.

40. Russell NS, Hoving S, Heeneman S, et al. Novel insights into pathological changes in muscular arteries of radiotherapy patients. Radiotherapy Oncology ; 92: 477-483, 2009.

41. AbuRahma AF, Robinson PA, Boland JP, et al. Complications of arteriography in a recent series of 707 cases: factors affecting outcome. Ann Vasc Surg; 7: 122-129, 1993.

42. Dublin BA, Karp NS, Kasabian AK, et al. Selective use of preoperative lower extremity arteriography in free flap reconstruction. Ann Plast Surg; 38: 404-407, 1997.

43. Cox CD, Tsikouris JP. Preventing contrast nephropathy: what is the best strategy? A review of the literature. J Clin Pharmacol; 44: 327-327, 2004.

44. Rubin GD, Schmidt AJ, Logan LJ, Sofilos MC. Multidetector row CT angiography of lower extremity arterial inflow and runoff: initial experience. Radiology; 221: 146-158, 2001.

45. Martin ML, Tay KH, Flak B, et al. Multidetector CT angiography of the aortoiliac system and lower extremities: a prospective comparison with digital subtraction angiography. AJR Am J Roentgenol; 180: 1085-1091, 2003. 
46. Met R, Bipat S, Legemate DA, et al. Diagnostic performance of computed tomography angiography in peripheral arterial disease: a systematic review and meta-analysis. Jama; 301: 415-424, 2009.

47. Miyoshi T, Kanematsu M, Kondo H, et al. Abdomen: angiography with 16-detector CT--comparison of image quality and radiation dose between studies with $0.625-\mathrm{mm}$ and those with $1.25-\mathrm{mm}$ collimation. Radiology; 249: 142-150, 2008.

48. Taylor GI, Doyle M, McCarten G. The Doppler probe for planning flaps: anatomical study and clinical applications. Br J Plast Surg; 43: 1-16,1990.

49. Iglehart JK. Health insurers and medical-imaging policy--a work in progress. N Engl J Med; 360 : 1030-1037, 2009.

50. von Schulthess GK, Steinert HC, Hany TF. Integrated PET/CT: current applications and future directions. Radiology; 238: 405-422, 2006. 


\section{Chapter 7}

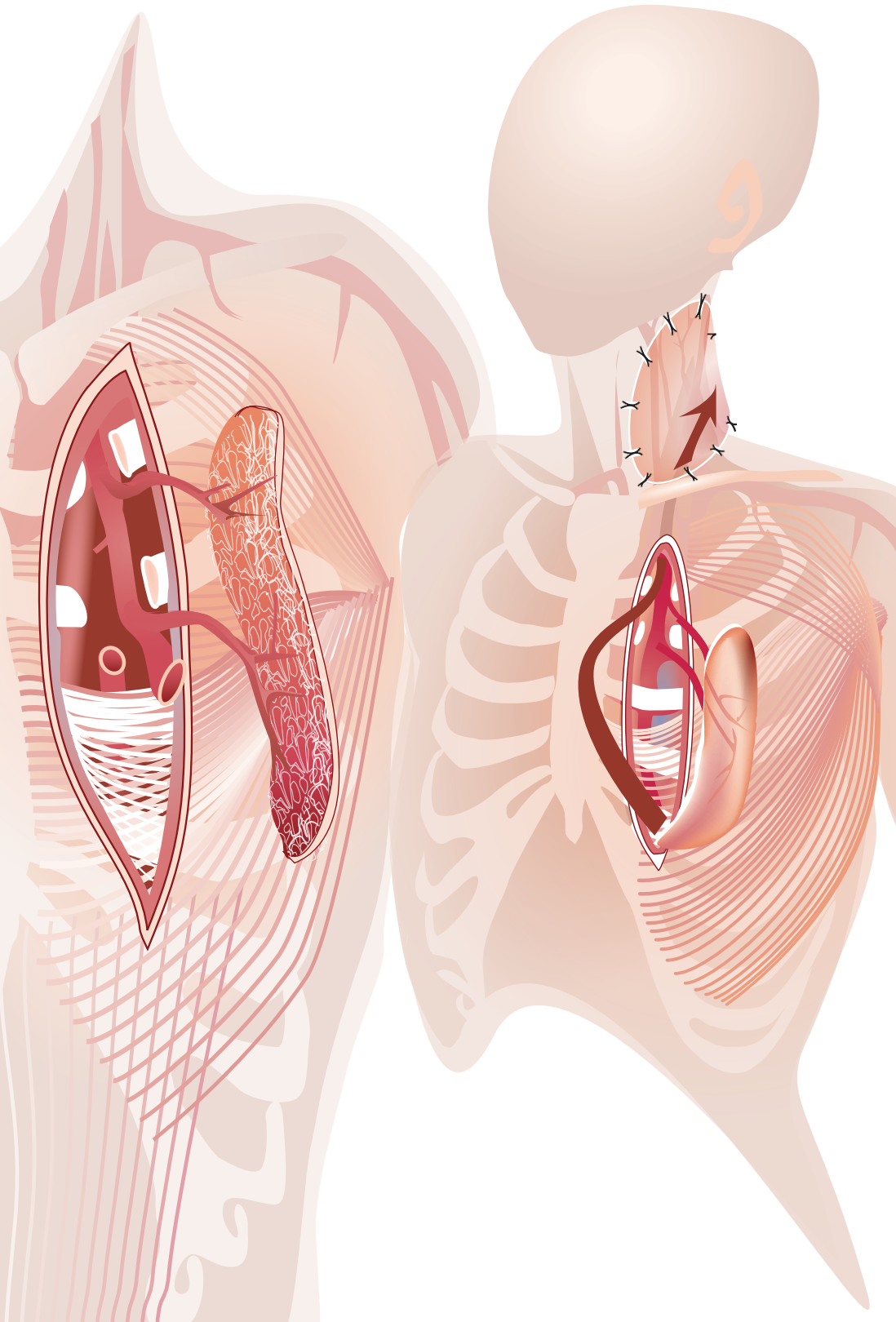


Head and neck reconstruction is more than performing a micro-anastomosis to fill a defect with a lump of tissue (Epilogue) 
Chapter 7 


\section{In search of the ideal flap}

Past

The opening chapter of this thesis paints a picture of the plastic surgeons' ongoing quest for the ideal technique of the repair of tissue defects. To date, many cutaneous, fasciocutaneous, musculocutaneous, and muscular pedicled or free flaps have been used, and are being used, for head and neck reconstructions. The choice of flap is to be determined by both the requirements of the recipient site, and the aim to optimally reduce the functional and aesthetic loss of the donor site. Old workhorses like the pectoralis major myocutaneous pedicled flap ${ }^{1,2}$ and radial forearm free flap ${ }^{3,4}$ have been refined to optimize the outcome at both sites. Meanwhile, chimeric flaps with different tissue components that are being fed by separate vessels that originate from a common pedicle have been proven very suitable for the reconstruction of head and neck defects. ${ }^{5,6}$

Local or loco-regional cutaneous or fasciocutaneous flaps play an important role in superficial head and neck defects and are by far superior to any distant flaps from an aesthetic point of view. ${ }^{7}$ Still, more complex defects may need bulky flaps to obliterate cavities. As such, muscular or musculocutaneous flaps may exceed (fascio-)cutaneous flaps because their malleability allows a better fit in deep crevices or on irregular surfaces. ${ }^{8}$ Furthermore, a skin grafted muscle flap may gives a better appearance and colour match in the head and neck area than a distant (fascio-)cutaneous free flap. Alternatively, a distant flap can be over-grafted with a split thickness skin graft from the calvarium to correct the colour and texture mismatch, but this requires an additional operation..$^{9,10}$

\section{Present}

Distant and loco-regional perforator flaps are the most recent and, without a doubt, the most exciting addition to our armamentarium. What can be easier than the design of a perforator cutaneous flap on the skin surface around an appropriate perforator? Depending on the desired pedicle length, no more than a superficial suprafascial dissection is required for local perforator flaps. Harvest of a muscle flap always requires a deep subfascial dissection. On the other hand, intramuscular dissection of the perforating vessels results in a flap with a longer pedicle length. Thus, the arc of rotation of a perforator pedicled flap is enhanced or the anastomosis and inset of a perforator free flap is facilitated. 
The use of perforator flaps rather than myocutaneous flaps features two main advantages. First, the dissection of the perforator out of the muscle means the muscle can be left in situ and innervated in cases where a musculocutaneous perforator flap is harvested. This results in a clear clinical benefit for the donor site. Second, there is a myriad of potential perforators available that can be used as a flap pedicle. Taylor and Palmer ${ }^{11}$ already showed that there are typically more than 300 fascial perforators in a human cadaver. Any of these may sustain a perforator flap as a free-style local pedicled flap or free-style free flap. ${ }^{12,13}$ This allows for an almost unlimited number of potential donor sites anywhere in the body, whereas only a few dozen muscles are similarly useful to be included in a musculocutaneous flap. This diversity of potential flaps and donor sites allows the surgeon to repair any given defect with tissue of similar texture, thickness, and colour in order to achieve a more refined reconstruction.

Does this make the use of perforator flaps the ideal soft tissue flaps "for all seasons" and, therefore, the uppermost step on the reconstructive ladder? In other words: does every defect need a perforator flap and are traditional flaps to be considered as obsolete and passé? The answer is an obvious "no" and, therefore, the role of perforator flap surgery in our reconstructive armamentarium needs to be discussed. First, the use of perforator flaps, like many new surgical procedures, features a learning curve that can be steep. Consequently, any novice primarily needs to gain experience with the relevant vascular anatomy and its required fine dissection. Second, obesity of the patient is almost a contra-indication for selection of a perforator flap for head and neck reconstruction. The use of the anterolateral thigh perforator free flap, popularized by Wei, ${ }^{14,15}$ is promoted as the ideal soft tissue flap and became one of the workhorses in head and neck reconstruction. This flap features versatility in tissue components and flap design in combination with negligible donor site morbidity. Because of the increasing obesity among the population of the Western society, however, the anterolateral thigh flap may loses its first-choice position despite outstanding results ${ }^{16,17}$ of its thinning by microdissection procedures. In these obese patients, skin grafted muscle flaps are usually less bulky, more extensible and more pliable. Moreover, the post-transfer atrophy of the muscle in the flap often imparts further contour improvement. In cases where the donor site of a perforator flap cannot be closed directly, a skin graft or transfer of another local flap needs to be applied. Contrastingly, harvesting a muscle flap more often than not results solely in a linear scar. In other words, even the use of perforator flaps needs further modifications and refinements. 


\section{Present(ed) refinements}

In the ongoing quest to reduce donor site morbidity, we previously adopted and adepted the use of the segmental pectoralis major pedicled island flap for the repair of partial hypopharyngeal defects. Despite our modifications ${ }^{2,18,19}$ to this flap, we wanted to further decrease donor site morbidity by eliminating the use of a large trunk muscle. A case report of Morain, Hallock, and Neligan presented in a book of Blondeel et al. ${ }^{20}$ stimulated us to investigate the vascular territory of the internal mammary artery perforators (IMAP) in order to find a reliable cutaneous or fasciocutaneous perforator flap to reconstruct this type of defects. The ink-injection study we performed provided us with the perfusion area of one single, dominant internal mammary perforator. This perforator was pre-dominantly located in the second intercostal space and the mean area of staining of one single dominant perforator was $19.4 \mathrm{~cm}$ craniocaudally, by $18.6 \mathrm{~cm}$ in mediolateral direction. Injection of an additional, non-dominant perforator proved not to expand the vascular territory of the dominant perforator. Although others investigated the vascular territory of the internal mammary perforators ${ }^{21,22}$ they did not focus on the role of the dominant perforator.

To assess the IMAP flap's feasibility as a pedicled flap for lower head and neck reconstructions, the arc of rotation of the flap on its dominant perforator had to be investigated. This arc of rotation is determined by the maximum length of the flap together with the maximum length of its pedicle. The pedicle length of the IMAP perforator flap equals the sum of the length of the perforating vessel from flap to the vessel's origin from the internal mammary vessels, plus the length of the mobilized internal mammary vessels towards the caudal aspect of the first rib (its highest pivot point). ${ }^{9}$ Cadaver measurements proved that mobilization of the internal mammary vessels doubled the pedicle length in cases where the perforator erupting through the second intercostal space was used. This enhances the arc of rotation of the IMAP flap in such a way that even high-located defects in the neck region can be reached.

The second aim of this study was to assess the clinical potential of the IMAP flap, both as a pedicle flap and as a free flap. Guided by our anatomical data we were able to use IMAP pedicled flaps of different sizes in a variety of defects in the neck and on the anterior chest wall. Pedicled IMAP flaps have been used by other groups ${ }^{21-25}$. All these authors supported our findings and found the IMAP island flap to address the aesthetic and functional requirements. Inclusion of more than one perforator or preexpansion allows for large flaps to be raised. Bilateral use of these flaps allows for even larger defects to be covered. Encouraged by our work with IMAP pedicled flaps, we performed three IMAP free flaps in head and neck cancer patients and we found the aesthetic results to be promising. To date, no other report of the IMAP free flap has been 
published but the IMAP free flap certainly deserves attention of reconstructive head and neck micro-surgeons.

Our study showed that the donor scar can be orientated either parasternally, or overlying the intercostal space. Parasternal V-Y advancement of an IMAP flap can be used to avoid nipple distorsion when closing supra- and infraclaviculair defects. ${ }^{26}$ Unlike the supraclavicular donor defects of a deltopectoral flap, all infraclavicular donor defects of our IMAP flaps could be closed primarily without the need of a skin graft. Furthermore, the use of the IMAP flap does not result in the dog-ears observed after the use of a deltopectoral flap. By subcutaneous tunnelling of the IMAP flap's pedicle the donor scar does not cross the clavicle. Likewise, application of an IMAP flap lacks the disadvantages of the (segmental) pectoralis major myocutaneous flap such as its bulky aspect, functional impairment, thoracic contour deficits, or skin paddle necrosis. In cases where tracheostomy defects ${ }^{21,26}$ or pharyngocutaneous ${ }^{27}$ fistulas are repaired with a pectoralis major flap, the bulk of this flap may easily fall over the tracheostomy and obstruct it. These challenging defects can easily be reconstructed with a thin and pliable pedicled flap based on a single cranial internal mammary artery perforator, preventing such secondary obstruction.

Use of the more inferiorly selected perforators allows for coverage of presternal defects. ${ }^{26,28}$ An even less inconspicuous donor scar can be gained if the flap is placed in the infra-mammary fold in women. ${ }^{28}$ Correction of a mild funnel chest deformity has been reported using an IMAP flap based on lower internal mammary artery perforators. $^{29}$

Simultaneously with our work, elegant three -and four-dimensional computed tomographic angiography studies of the vascular anatomy of the internal mammary artery perforators were published. 22,30,31 These studies show direct and indirect linking arteries and veins between adjacent perforators, thereby explaining how perfusion extends to the vascular territory of nearby perforators. These direct linking vessels are located halfway between dermis and pectoral fascia, while the indirect linking vessels are located at the subdermal level. Hence, thinning of an IMAP flap is possible if dissection does not extend beyond half the flap's subdermal thickness. The potential of thinning makes the IMAP flap even more suitable for head and neck reconstruction. Likewise, a report of pre-expansion of the anterior chest in a burn patient with anterior neck scar contracture has meanwhile been reported to result in a large, pliable and thin IMAP flap with a large arc of rotation. ${ }^{22}$ 


\section{Future}

Advances in autologous reconstructive concepts, principles, and techniques like perforator flap surgery allow us to close a head and neck wound of almost any extension. ${ }^{32}$ However, when no autologous donor tissue is available, e.g. in severe burn victims, when all autologous donor sites have been used, or when multiple facial functional units are missing or deformed we can fall short in accomplishing our goal of making a human face capable of interacting with society. In these circumstances composite tissue allotransplantation (CTA) of the face becomes a potential option. Facial composite tissue allotransplantation was initiated in 2005 in France, with the successful transplantation of the mid-face. Since, a total of 21 cases of such transplants ${ }^{33}$ have been reported, of which 19 are still alive. This experience has shown that composite tissue allotransplantation of the face is surgically feasible, ${ }^{34-35}$ and features encouraging functional, aesthetic, immunological, and psychological results. So far, there has been a reduction in chronic pain level and social isolation, improvement in facial expression, and return of functions such as eating, drinking and speaking. ${ }^{34-36}$

Will facial composite tissue allotransplantation be the panacea for all large and complex head and neck defects in the future? The major drawbacks of all allotransplantation procedures are the potential drug toxicity, opportunistic infections, and malignancies that are associated with the life-long dependence on immunosuppressive drugs. ${ }^{37}$ Despite major advances over the last decades, immunosuppressive protocols lead to morbidity and are likely to be contra-indicated in head and neck oncologic patients. Furthermore, acute or chronic graft-versus-host or host-versus-graft rejection resulting in the loss and removal of the graft is a very serious problem that puts a facial transplant patient back in a condition that will be even worse than the initial state. Also, similarly to solid organ transplantation any program of facial allotransplantation has to deal with the limited availability of suitable donors. Donor availability will be more limited than in solid organ transplantation programs because of concerns about the aesthetic match of the transplant and the recipient.

Although the early experience with facial composite tissue allotransplantation in general has been far more positive than predicted, ${ }^{33}$ it will take a lot more experience before transplantation may eventually become a first-line reconstructive option for patients with severe facial disfigurements. Hence, innovations, modifications, and refinements of autologous reconstructive techniques are still needed. 


\section{"The remover should not be the repairer" (Sir Harold D. Gillies)}

The reconstructive surgeon needs to be familiar with this full spectrum of reconstructive options, innovations, modifications and refinements. Only then, is he or she optimally equipped to select the method of reconstruction that will give the best aesthetic and functional outcome for each individual patient. Reconstructive surgery is not just filling the defect with a lump of tissue by use of micro-anastomoses but the complex combination of a detailed investigation of what is missing. It actually calls at the recipient site for a well-balanced choice of technique that will offer the patient an optimal functional and aesthetic outcome in both the recipient and donor site. The reconstructive surgeon needs the surgical experience necessary to perform any reconstructive procedure with utmost finesse. The selected flap has to fit the defect; the defect is not to be adapted to the flap that happens to be available. Colour match, bulk and general appearance can be as important as the functional outcome. Adequate tumour control and mere coverage of the defect are no longer sufficient to meet head and neck patients' expected quality of life.

New flaps and techniques are being presented in fast succession and to keep up with this progress is a full-time task. Each new technique has to be thoroughly understood and weighted against established techniques that have been used successfully for many years. Innovation and refinement are the core of plastic and reconstructive surgery. Again, it were plastic surgeons who developed the concept of perforator flap surgery and they are now accustomed to raise many different perforator flaps all over the body. Often, plastic surgeons have acquired the technique of perforator flap dissection merely by doing autologous breast reconstruction with deep inferior epigastric artery perforator flap or thoracodorsal artery perforator flaps. This surgical skill is combined with an imaginative faculty of three-dimensional solutions for through-and-through defects that are common in head and neck ablative surgery. The time that free flap surgery and perforator flap surgery were considered to be only feasible in a few hightech centres in the hands of highly trained surgeons has passed. Such surgery is now part of many general plastic surgeons' daily practice.

In many of the large centres where head and neck cancer patients are being treated, ablative surgeons currently feel confident to also perform the reconstructive part of the treatment. The exclusion of plastic surgical expertise in the multidisciplinary treatment of head and neck cancer patients puts unnecessary stress on these ablative surgeons as they should keep up to date with both the oncologic and the reconstructive aspect of their treatment. Because they cannot possibly cope with the fast succession of new reconstructive innovations and refinements, these combined remover-repairers 
deprive their patients from state-of-the-art techniques by such exclusion. Ablative surgeons simply cannot incorporate all unique and creative solutions introduced by plastic surgeons in their armamentarium. This may influence the way they execute the resection, with or without them being aware of it.

It is time to re-establish Gillies' adage that the remover should not be the repairer. This way, ablative surgeons only have to concentrate on what they are primarily trained for: the most adequate treatment and ablation of the tumour. They should feel free to perform the oncologically optimal resection, no more and certainly no less, without any concern about the closure of the defect afterwards. The plastic surgeon only has to focus on finding the best solution for the resulting defect. This solution is, then, again based on a continued, full-scaled plastic and reconstructive surgical training and the additional experience with reconstructive techniques applied elsewhere on the body. We offer the findings that are presented in this thesis as a token to all ablative surgeons who themselves perform the reconstructions as, jointly, we can perform more (perforator) flaps and gain more experience for the benefit of our patients. It is time to let all new knowledge and input from different disciplines again come together in a true multidisciplinary approach to ensure that head and neck cancer patients receive the best treatment. Mankind has evolved by returning from isolated islands to the big and open mainland to profit from the qualities of other cultures. Together Everyone Achieves More! 


\section{Conclusions}

The following conclusions may be drawn from the studies and clinical work presented in this thesis:

- $\quad$ one single, dominant internal mammary artery perforator vascularises a large part of the anterior hemithorax. Inclusion of a non-dominant perforator does not add more surface to this vascular territory

- in more than two third of the cases, the dominant internal mammary artery perforator is located in the second intercostal space

- the mean length of the dominant perforator is $47 \mathrm{~mm}$ and in this length can be doubled by inclusion of the internal mammary artery up to the level of the first rib

- the arc of rotation of a pedicled internal mammary artery perforator flap is enhanced by mobilisation of the internal mammary vessel up to the level of the first rib

- a pedicled internal mammary artery perforator flap is a consistently reliable flap for reconstructions in the lower face, neck and anterior chest wall

- a free internal mammary artery perforator flap is an useful and clinical feasible adjunct to the microsurgical armamentarium for reconstructions of cutaneous defects in the upper head and neck region

- previously performed diagnostic CT-scans and MRI-scans that included the parasternal region usually allow sufficient preoperative assessment of the internal mammary perforators for reconstructive procedures. 


\section{References}

1. Ramakrishnan VR, Yao W, Campana JP. Improved skin paddle survival in pectoralis myocutaneous flap reconstruction of head and neck defects. Arch Facial Plast Surg. 11, 306-310, 2009.

2. Corten EML, Schellekens PPA, Hage JJ, Kon M. Clinical outcome after pedicled segmental pectoralis major island flaps for head and neck reconstruction. Ann Plast Surg. 63, 292-296, 2009.

3. Hsieh CH, Kuo YR, Yao SF, Liang CC, Jeng SF. Primary closure of radial forearm flap donor defects with a bilobed flap based on the fasciocutaneous perforator of the ulnar artery. Plast Reconstr Surg. 113, 1355-1360, 2004.

4. Elliot D, Bardsley AF, Batchelor AG, Soutar DS. Direct closure of the radial forearm flap donor defect. Br J Plast Surg. 41, 358-360,1988.

5 Kuo Y, Jeng S, Wei FC, Su C, Chien C. Functional reconstruction of complex lip and cheek defect with free composite anterolateral thigh flap and vascularized fascia. Head Neck. 30, 1001-1006, 2008.

6. Lin YT, Lin CH, Wei FC. More degrees of freedom by using chimeric concept in the applications of anterolateral thigh flap. J Plast Reconstr Aesth Surg. 59, 622-627, 2006.

7. Hofer SOP, Mureau MAM. Pedicled perforator flaps in the head and neck. Clin Plast Surg. 37, 627$640,2010$.

8. Hallock GG. In an era of perforator flaps, are muscle flaps passé? Plast Reconstr Surg. 123,13571363, 2009.

9. Walton RL, Cohn AB, Beahm EK. Epidermal overgrafting improves coloration in remote flaps and grafts applied to the face for reconstruction. Plast Reconstr Surg. 121, 1606-1613, 2008.

10. Lannon DA, Novak CB, Neligan PC. Resurfacing of colour-mismatched free flaps on the face with split-thickness skin grafts from the scalp. J Plast Reconstr Aesthet Surg. 62, 1363-1366, 2009.

11. Taylor Gl, Palmer JH. The vascular territories (angiosomes) of the body: experimental study and clinical applications. Br J Plast Surg. 40, 113-141,1987.

12. Wei FC, Mardini S. Free-style free flaps. Plast Reconstr Surg.114, 910-916, 2004.

13. Wallace CG, Kao HK, Jeng SF, Wei FC. Free-style flaps: a further step forward for perforator flap surgery. Plast Reconstr Surg.124, 419-426, 2009.

14. Wei FC, Vivek J, Celik N, Chen H, Chuang DC, Lin C. Have we found an ideal soft-tissue flap? An experience with 672 anterolateral thigh flaps. Plast Reconstr Surg. 109, 2219-2226; discussion 2227-2230, 2002.

15. Lutz BS, Wei FC. Microsurgical workhorse flaps in head and neck reconstruction. Clin Plast Surg. 32, 421-430, 2005.

16. Kimura N, Satoh K, Hosaka Y. Concept and anatomical basis of microdissected tailoring method for free flap transfer. Plast Reconstr Surg.123, 152-162, 2009.

17. Kimura N, Satoh K, Hasumi T, Ostuka T. Clinical application of the free thin anterolateral thigh flap in 31 consecutive patients. Plast Reconstr Surg. 108, 1197-1208; discussion 1209-1210, 2001.

18. Corten EML, Schellekens PPA, Bleys RLAW, Hage JJ, Kon M. Function of the clavicular part of the pectoralis major muscle after transplantation of its sternocostal part. Ann Plast Surg. 58, 392-396, 2007.

19. Corten EML, Schellekens PPA, Bleys RLAW, Kon M. The nerve supply to the clavicular part of the pectoralis major muscle: an anatomical study and clinical application of the function-preserving pectoralis major island flap. Plast Reconstr Surg. 112, 969-975, 2003.

20. Blondeel PN, Morris SF, Hallock GG, Neligan PC. Perforator flaps. Anatomy, Technique \& Clinical Apllications. Quality Medical Publishing, St Louis MI, 2006.

21. Yu P, Roblin P, Chevray P. Internal mammary artery perforator (IMAP) flap for tracheostoma reconstruction. Head Neck 28, 723-729, 2006.

22. Saint-Cyr M, Schaverien M, Rohrich RJ. Preexpanded second intercostal space internal mammary artery pedicle perforator flap: case report and anatomical study. Plast Reconstr Surg.123, 1659$1664,2009$. 
23. Iyer NG, Clark JR, Ashford BG. Internal mammary artery perforator flap for head and neck reconstruction. ANZ J of Surg. 79, 799-803, 2009.

24. Vesely MJJ, Murray DJ, Novak CB, Gullane PJ, Neligan PC. The internal mammary artery perforator flap. Ann Plast Surg. 58,156-167, 2007.

25. Neligan PC, Gullane PJ, Vesely MJJ, Murray DJ. The internal mammary artery perforator flap: New variation on an old theme. Plast Reconstr Surg. 119, 891-893, 2007.

26. Schellekens PPA, Hage JJ, Paes EC, Kon M. The internal mammary artery perforator pedicled island flap for reconstruction of the lower head and neck and supraclavicular region. Clin Otolaryng. 35, 332-336, 2010.

27. Pirgousis $P$, Fernandes R. Use of the internal mammary artery perforator flap for repair of pharyngocutaneous fistulas in the vessel-depleted neck. J. Oral Maxillofac. Surg. 69, 1225-1228, 2011.

28. Schmidt M, Aszmann OC, Beck H, Frey M. The anatomic basis of the internal mammary artery perforator flap: a cadaver study. J Plast Reconstr Aesth Surg. 63, 191- 196, 2010.

29. Schwabegger AH, Piza-Katzer H, Pauzenberger R, Del Frari B. The internal mammary artery perforator (IMAP) breast-flap harvested from an asymmetric hyperplastic breast for correction of a mild funnel chest deformity. Aesth Plast Surg 35, 928-932, 2011.

30. Wong C, Saint-Cyr M, Rasko Y, Mojallal A, Bailey S, Myers S, Rohrich RJ. Three-and four- dimensional arterial and venous perforasomes of the internal mammary artery perforator flap. Plast Reconstr Surg. 124, 1759 - 1769, 2009.

31. Gillis JA, Prasad V, Morris SF. Three-dimensional analysis of the internal mammary artery perforator flap. Plast Reconstr Surg. 128, 419e-426e, 2011.

32. Gottlieb L, Agarwal S. Autologous Alternatives to Facial Transplantation. J Reconstr Microsurg 28, 49-62, 2012.

33. Shanmugarajah K, Hettiaratchy S, Clarke A, Butler PEM. Clinical outcomes of facial transplantation: a review. Int J Surg, 9, 600-607, 2011.

34. Lantieri LA. Face transplant: learning from the past, facing the future. Proc Am Philos Soc 155, 23 $28,2011$.

35. Barret JP, Serracanta J, Collado JM, Garrido A, Salamero P, Pont T, Masnou N, Arana E, Arno A, Garcia V, Sancho J, Ruiz M. Full face transplant: the first case report. Ann. Surg. 254, 252-256, 2011.

36. Dubernard J-M. Hand and face allografts: myth, dream, and reality. Proc Am Philos Soc. 155, 13-22, 2011.

37. Hettiaratchy S, Randolph MA, Petit F, Lee WPA, Butler PEM. Composite tissue allotransplantation--a new era in plastic surgery? Br J Plast Surg. 57, 381-391, 2004. 


\section{Chapter 8}

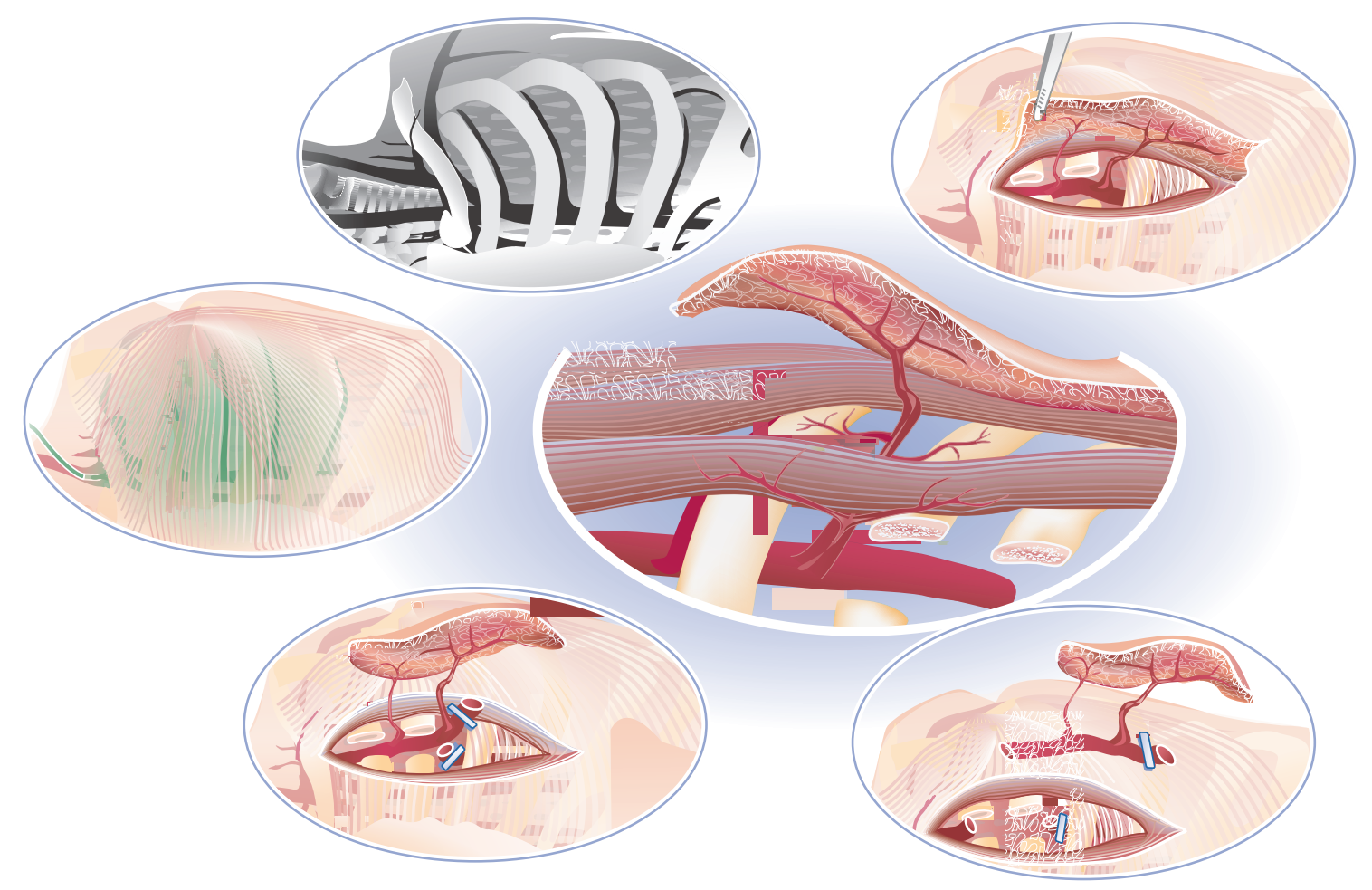


Summary 
Chapter 8 


\section{Summary}

In chapter 1 the evolution of our knowledge of the vascular anatomy of the skin is presented and put into perspective with the discovery of flaps in the past century. Reconstructive surgery evolved as a result of the enormous numbers of World War I and II victims, long before profound knowledge of the vascularity of flaps was present. At present, sophisticated imaging techniques have given us at present a thorough understanding of the vascularity of tissues so that randomly vascularized fasciocutaneous flaps used a century ago evolved into the perforator flaps we use today. The deltopectoral flap of Bakamjian, introduced in the late 1960's for ablative head and neck reconstruction is in fact the predecessor of perforator flaps. Although succeeded by many other flaps the concept of using anterior chest wall skin and subcutaneous tissue for head and neck reconstruction is logical.

The actual concept of vascularity of skin perforator flaps is that a main source artery supplies a skin region with one or more perforators which may be musculocutaneous, septocutaneous or following a direct course to the skin. The internal mammary vessels send off perforators through the intercostal muscles and the pectoralis muscle to supply the skin of the anterior chest wall. Predominantly the perforatoring vessels through the second intercostal space are the largest. Based on this information we investigated the possibilities to use the anterior chest wall skin as a flap for head and neck reconstruction. In chapter $\mathbf{2}$ we show that the dominant perforator of the internal mammary vessels supplies a large territory of the anterior chest wall skin with a mean of $19,4 \mathrm{~cm}$ in craniocaudal direction and $18,6 \mathrm{~cm}$ in mediolateral direction. Additional injection studies of the non-dominant perforators did not lead to any substantial enlargement of this territory. Even in cases where the dominant perforator was located in a different intercostal space, the skin staining showed similar dimensions.

In almost $40 \%$ of the injected cadavers there was staining across the midline of the sternum mainly in the cranial part of the vascular territory. In contrast to the deltopectoral flap which was based on several internal mammary artery perforators, we showed that one single dominant perforator is capable to perfuse a large part of the hemi-thorax allowing flaps to be designed in different directions with large dimensions.

The usefulness of a flap depends on its dimensions and length of the vascular pedicle. In chapter $\mathbf{3}$ we describe the anatomy of the internal mammary vessels and their perforators. The length of the dominant perforator and the enhanced vascular pedicle of the IMAP (Internal Mammary Artery Perforator) flap were measured in 27 fresh cadaver hemi-thoraxes. The mean length of the 27 dominant perforators was $47 \mathrm{~mm}$ (range: 
30-66 mm). By removing cartilage from the second rib, the mean length of the vascular pedicle, enhanced up to the level of the first rib, could be doubled to $92 \mathrm{~mm}$ when based on the second perforator (0.67). In five cases (0.19), where the third perforator was dominant, the mean length of the enhanced pedicle was $104 \mathrm{~mm}$, whereas it was $61 \mathrm{~mm}$ in four cases $(0.15)$ where the first perforator was dominant.

The outcome supported the feasibility of the flap as a pedicled flap in head and neck reconstruction. Enhancement of the vascular pedicle by mobilisation of the internal mammary vessels, combined with the described dimensions leads to an arc of rotation that even high-located defects in the upper head and neck can be reached.

In chapter $\mathbf{4}$ we report of the clinical use of the pedicled internal mammary artery perforator flap in seven patients. Three pedicled flaps were used to reconstruct large lateral neck defects. These flaps had enhanced vascular pedicles and the pivot point was at the caudal aspect of the first rib. Part of the flap was deepithelialized to be passed under a skin bridge over the clavicle.

Two flaps were island flaps for upper sternal and tracheotomy defects. In these flaps only the perforator was mobilised without pedicle enhancement. The two remaining flaps were used to reconstruct defects of the chest wall; one was an "enhanced" flap for a defect in the deltopectoral groove, the other was an island flap without pedicle enhancement and was used for a large, low sternal defect.

All flaps healed without complications, one flap (low sternal defect) had to be treated briefly by leeches due to venous congestion. All donor sites could be closed primarily . We showed that the internal mammary artery perforator flap has properties that make it suitable for use as a free flap in head and neck reconstruction: it has a large perforator based on a vascular pedicle of adequate length which supplies a large skin territory. The thorax wall skin superiorly mimics the characteristics of the regional integument. In chapter 5 we present the results of three IMAP free flaps varying from $7 \times 4 \mathrm{~cm}$ to $10 \times 6$ $\mathrm{cm}$ in three patients with upper head and neck defects. Coverage with excellent texture and colour match was uneventfully obtained and the flaps' donor sites were primarily closed in all three cases.

Our experience indicates that the free IMAP flap is a valuable alternative and should be available in the armamentarium of every microsurgical head and neck reconstructive surgeon. 
Proper planning of an IMAP pedicled or free flap includes preoperative assessment of the internal mammary perforators, primarily to distinguish the dominant perforator in cases where the flap can be vascularized by one perforator only. Laser-Doppler flowmetry, intra-luminal arteriography, CT-angiography or MR-angiography is used for such assessment. In chapter 6 we report that these examinations often may be rendered superfluous by assessment of previously performed, diagnostic examinations. Sufficient information on the dominant IMAP could be obtained from randomly picked thoracic CT-scans of 12 head and neck cancer patients and 12 breast cancer patients, and from the mammary MRI of 12 breast cancer patients. We also showed retrospectively that previous diagnostic examinations were available and informative regarding the level of the dominant perforator in $60 \%$ of the patients who underwent an IMAP-flap head and neck reconstruction, and $100 \%$ of the women who consecutively underwent a DIEP flap mammary reconstruction. Therefore we advocate re-assessment of such previous examinations before ordering additional angiography and suggest to include the parasternal region in diagnostic scans.

Chapter 7 includes an epilogue/discussion and the conclusions of this thesis. The role of perforator flap surgery in reconstructive surgery is discussed. Furthermore, we stress the importance of incorporating creative ideas from plastic surgeons in the multidisciplinary approach of head and neck cancer patients.

In the future perspectives we evaluate the role of composite tissue allotransplantation of the face as the uppermost treatment of replacing like with like in reconstructive head and neck surgery. 


\section{Chapter 9}
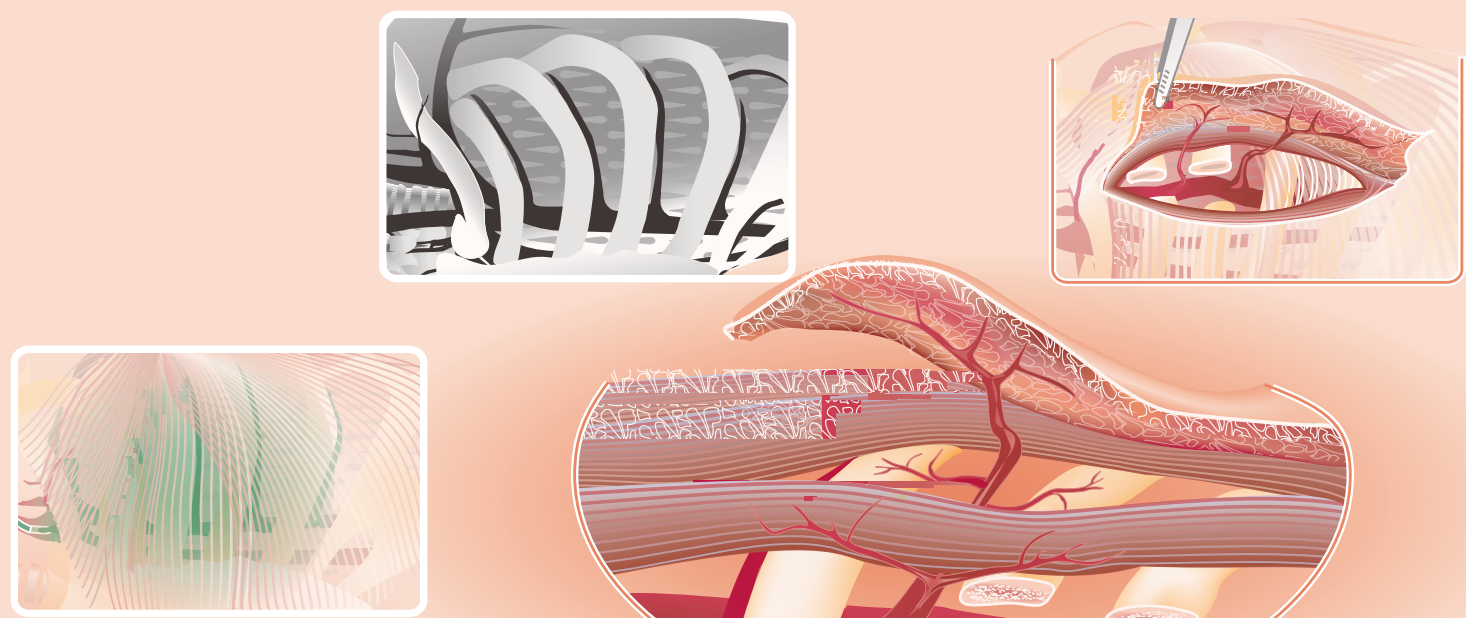
Nederlandse samenvatting

Dankwoord

Curriculum Vitae 
Chapter 9 


\section{Samenvatting}

In hoofdstuk 1 wordt beschreven hoe we onze kennis hebben verkregen omtrent de vascularisatie van de huid en hoe dit zich verhoudt tot de ontwikkeling van de chirurgie van (huid)lappen in de afgelopen eeuw. De reconstructieve chirurgie heeft zich voornamelijk ontwikkeld uit de oorlogschirurgie waarbij chirurgen gedurende de eerste en tweede wereldoorlog geconfronteerd werden met ontelbare gemutileerde slachtoffers zonder dat men enige kennis had over de vascularisatie van (huid) lappen. Onder andere door verbeterde afbeeldingtechnieken hebben we nu meer adequate kennis over de diverse lappen, dusdanig dat de in het verleden gebruikte "random" gevasculariseerde fascio-cutane lappen zijn geëvolutioneerd tot de huidige perforatorlappen.

De deltopectorale lap van Bakamjian, geïntroduceerd eind jaren 60 van de vorige eeuw voor reconstructieve hoofd-hals chirurgie kan beschouwd worden als een van de voorlopers van de huidige perforatorlappen. Alhoewel deze lap is opgevolgd door vele andere lappen is het concept om huid en subcutis van de thorax te gebruiken voor hoofd-hals reconstructies logisch.

De huidige opvatting over de vascularisatie van de huid is dat er perforatoren bestaan die naar de huid toe verlopen en daar een circumscript gebied van bloed voorzien. Deze perforatoren zijn afkomstig van een "hoofd-arterie" en lopen of direct naar de huid, of via een spier (musculo-cutaan) dan wel via een septum (septo-cutaan) naar de huid toe.

De arterie en vene mammaria interna geven perforatoren af die door de intercostaal spieren en de musculus pectoralis major naar de huid van de thorax verlopen. Daarbij is de perforator door de tweede intercostaal ruimte meestal de grootste. Met deze informatie in gedachten hebben we de mogelijkheden onderzocht om een lap te ontwikkelen afkomstig van de thorax welke gebruikt zou kunnen worden voor reconstructies in het hoofd-hals gebied. In hoofdstuk $\mathbf{2}$ tonen we aan dat de dominante perforator van de mammaria interna vaten een groot huidgebied voorziet op de thorax met een gemiddelde lengte van 19,4 cm in cranio-caudale richting en $18,6 \mathrm{~cm}$ in mediolaterale richting. Aanvullende injectie studies van de niet-dominante perforator tonen echter geen verdere substantiële vergroting van dit verzorgingsgebied aan.

In bijna 40\% van de ingespoten kadavers was er kleuring voorbij de middenlijn van het sternum aanwezig, hoofdzakelijk in het craniale gedeelte van het verzorgingsgebied. 
In tegenstelling tot de deltopectorale lap die gebaseerd was op meerdere perforatoren van de mammaria interna vaten hebben we hiermee aangetoond dat een enkele, dominante perforator in staat is om een groot gedeelte van de huid van een halve thorax te perfunderen waardoor er lappen kunnen worden gecreëerd in verschillende richtingen met aanzienlijke afmetingen.

De bruikbaarheid van een lap wordt onder andere bepaald door zijn maximale afmetingen en de maximale lengte van de vaatsteel. In hoofdstuk $\mathbf{3}$ beschrijven we de anatomie van de mammaria interna vaten en hun perforatoren. De lengte van de dominante perforator en de vermeerderde lengte van de vaatsteel van de IMAP (Internal Mammary Artery Perforator) lap werden gemeten in de halve thoraxen van 27 verse kadavers. De gemiddelde lengte van de 27 dominante perforatoren was $47 \mathrm{~mm}$, (variatiebreedte: 30-66 mm). Door het kraakbeen van de tweede rib te verwijderen kon de vaatsteel worden verlengd tot aan het niveau van de eerste rib waardoor de vaatsteel lengte verdubbelde naar $92 \mathrm{~mm}$ indien de tweede intercostaal perforator dominant was (0.67). In vijf kadavers (0.19) was de derde intercostaal perforator dominant waarbij de gemiddelde lengte van de verlengde vaatsteel $104 \mathrm{~mm}$ bedroeg, in vier kadavers was de eerste intercostaal perforator dominant en bedroeg de verlengde vaatsteel gemiddeld $61 \mathrm{~mm}$.

Deze uitkomst ondersteunt het idee om de IMAP lap als gesteelde lap te gebruiken bij hoofd-hals reconstructies. Verlenging van de vaatsteel door het mobiliseren van de mammaria interna vaten in combinatie met de eerdere genoemde afmetingen van de lap maken het mogelijk om zelfs hoog gelokaliseerde defecten in het hoofd-hals gebied te bereiken.

In hoofdstuk 4 melden we over het klinisch gebruik van de gesteelde IMAP lap bij zeven patiënten. Drie gesteelde lappen werden gebruikt om grote laterale nekdefecten te reconstrueren. Deze lappen hadden een verlengde vaatsteel en het draaipunt was gelegen ter hoogte van het caudale gedeelte van de eerste rib. Een gedeelte van de lap werd gedeëpithelialiseerd en kwam daarbij te liggen onder een huidbrug ter hoogte van de clavicula.

Twee lappen waren eilandlappen ter reconstructie van een craniaal sternum defect en een defect rondom een tracheostoma. Bij deze lappen werd de perforator uitgeprepareerd zonder verdere verlenging van de vaatsteel.

De twee overige lappen werden gebruikt om defecten van de anterieure thorax te reconstrueren; een lap was een "verlengde" lap die werd gebruikt om een defect in de deltopectorale groeve te reconstrueren, de andere was een "niet-verlengde"lap die werd 
gebruikt voor een groot, laag sternaal defect. Alle lappen genazen zonder complicaties, een lap (laag sternaal defect) moest kortstondig met medicinale bloedzuigers worden behandeld in verband met veneuze stuwing in een deel van de lap.

We hebben aangetoond dat de arteria mammaria interna perforator lap eigenschappen heeft die de lap geschikt maken om te gebruiken als vrije lap bij hoofd-hals reconstructies. Een groot huidgebied wordt door een grote perforator, afkomstig van een vaatsteel van voldoende lengte geperfundeerd. Daarbij heeft de huid van de thorax veel overeenkomsten met de huid van het hoofd-hals gebied. In hoofdstuk $\mathbf{5}$ presenteren we de resultaten van drie vrije IMAP lappen variërend in grootte van $7 \times 4 \mathrm{~cm}$ tot $10 \times 6 \mathrm{~cm}$ bij drie patiënten met defecten in het bovenste hoofd-hals gebied. Hierbij werd een bedekking verkregen met een uitstekende structuur en kleurovereenkomst en tevens konden de donorplaatsen in alle drie de casussen primair worden gesloten. Onze ervaring geeft aan dat de vrije IMAP lap een waardevol alternatief is en deel moet uitmaken van het microchirurgische armamentarium van iedere reconstructieve hoofd-hals chirurg.

Juiste planning van een gesteelde of een vrije IMAP vereist een preoperatieve beoordeling van de perforatoren van de mammaria interna vaten, allereerst om de dominante perforator op te sporen en met name bij gevallen waar de lap slechts door één perforator wordt gevasculariseerd. Laser-Doppler flowmetry, intra-luminale arteriografie, CT-angiografie of MR-angiografie worden gebruikt voor een dergelijke beoordeling. In hoofdstuk 6 melden we dat deze onderzoeken vaak overbodig zijn indien reeds eerder verricht diagnostisch onderzoek hiervoor wordt herbeoordeeld. Voldoende informatie over de dominante IMAP kon worden verkregen van willekeurig uitgekozen CT scans van 12 oncologische hoofd-hals patiënten en 12 patiënten met borstkanker en de MRI scans van 12 borstkanker-patiënten. Verder hebben we retrospectief aangetoond dat in $60 \%$ van de patiënten die een IMAP lap kregen en in $100 \%$ van de patiënten die een DIEP borstreconstructie ondergingen de informatie aangaande de dominante perforator beschikbaar was in reeds eerder uitgevoerd diagnostisch onderzoek. Daarom adviseren wij om een herbeoordeling te verrichten van reeds eerder uitgevoerde onderzoeken voordat bij dergelijke patiënten aanvullende angiografie wordt aangevraagd en, indien er diagnostische scans worden verricht, hierbij altijd de parasternale regio te laten mee scannen. 
Chapter 9

Hoofdstuk 7 bevat de epiloog/discussie en de conclusies van dit proefschrift. De rol van perforatorlap chirurgie binnen de reconstructieve chirurgie wordt hierin bediscussieerd. Daarnaast wijzen we op het belang van het incorporeren van innovatieve ideeën vanuit de plastische chirurgie en het betrekken van plastisch chirurgen bij de multidisciplinaire benadering van oncologische hoofd-hals patiënten.

In de toekomstperspectieven wordt de rol van allologe gelaatstransplantatie belicht als zijnde de ultieme reconstructie mogelijkheid waarbij hoofd-hals defecten zoveel mogelijk met "like-tissue" worden gereconstrueerd. 


\section{Dankwoord}

Lectori Salutem,

Toen mij enkele jaren geleden de toekomst werd voorspeld waarbij, vanuit een glazen bol gezien werd medegedeeld dat er in september 2012 een belangrijke gebeurtenis stond te wachten, kon ik niet bevroeden dat hiermee gedoeld werd op het beëindigen van dit proefschrift.

Voor dit laatste ben ik een aantal mensen dank verschuldigd:

Prof. dr. M. Kon, hooggeleerde promotor, oud-opleider, beste Moshe. "Wordt het niet eens tijd dat je zelf promoveert" waren enkele jaren geleden jouw prikkelende woorden. Mijn twijfels omtrent het slagen van een dergelijk traject heb jij op meesterlijke wijze getorpedeerd en met de juiste mensen aan boord hebben we koers gezet zodat er uiteindelijk toch een manuscript tot stand kwam.

Als Pater Familias waak jij al jaren over jouw stafleden en assistenten en jouw oprechte belangstelling voor ons wel en wee heb ik altijd erg in je gewaardeerd. Jij wist ook precies hoe je een vakgroep Plastische chirurgie van een academisch ziekenhuis in formatie kon houden dusdanig dat we al jarenlang een hechte groep vormen. In deze sfeer kon ook de IMAP lap zijn gestalte krijgen.

Ik weet zeker dat jij net zo blij bent als ik dat het boekje er uiteindelijk toch is gekomen en ik dan ook aan "jouw muur" kan komen te hangen. Ik dank je voor al de steun die je me in de afgelopen jaren hebt gegeven.

Prof, ik kijk met zeer gemengde gevoelens uit naar jouw naderende emeritaat.

Dr. J.J. Hage, copromotor, waarde Joris. Jouw inzet bij de begeleiding van dit manuscript zijn (figuurlijk )" met geen pen te beschrijven". Zonder jou was dit boekje er niet gekomen en de promotor wist als geen ander dat we met jouw persoon aan boord koers konden zetten. Tussen het restaureren van je huis door wist te reviseren en te regisseren. Met jouw gevleugelde "Onwards and Upwards" wist jij een ieder te motiveren. Ik beschouw het als een grote eer dat deze "legende" mijn co-promotor is. I have been standing on the shoulder of a giant.

Beste JJ, vele, vele malen dank.......! 
Drs. E.C. Paes, lieve Emma. Als student kwam je bij me voor onderzoek en op een onnavolgbare manier heb jij de anatomische studies van dit proefschrift vlot getrokken. Met passie, creativiteit en handigheid heb jij je gestort op de kadaverdissecties en bewezen dat wij hier te maken hadden met een plastisch chirurg in de dop. Je ben een onmisbare schakel geweest in de totstandkoming van dit manuscript en ik ben je veel dank verschuldigd. Ik ben er trots op dat mijn paranimf bent en me terzijde staat. Nog trotser ben in op het feit dat jij bij ons in Utrecht in opleiding komt.

\section{Heren van de Anatomie, Prof. dr. Ronald Bleys, Willem van Wolferen en Simon}

Plomp. Wat een voorrecht is het geweest om met de vakgroep anatomie samen te mogen werken. Niets is er te veel, alles kan en er wordt, letterlijk en figuurlijk, alles uit de kast gehaald om een project tot slagen te brengen. De prachtige verhalen van Willem over projecten uit het verleden hielden de moed er vaak in.

Prof. dr. Bleys, Ronald, wat ben ik blij dat je in Utrecht bent gebleven en het welverdiende hoogleraarschap hebt toegewezen gekregen. De Faculteit Geneeskunde mag zich in de handen knijpen met dergelijk vakkundig en aimabel hoogleraar! Ik ben dan ook zeer vereerd dat $\mathrm{jij}$, als mede-auteur van twee artikelen van dit proefschrift, voorzitter bent van de leescommissie.

Prof. dr. R. Koole, Prof. dr. R. van Hilligersberg en prof. dr. R. van der Hulst zijn bereidheid geweest om onder voorzitterschap van prof dr. R.L.A.W. Bleys, zitting te nemen in de leescommissie. De hooggeleerde vier $\mathbf{R}^{\prime}$ en (Ronald, Ron, Richard en René) hebben dit manuscript kritisch beoordeeld en hun goedkeuring uitgesproken, waarvoor hartelijk dank.

Collega-stafleden, we vormen al jarenlang een hecht team. Daar mogen we trots op zijn en in deze setting is het ook mogelijk geweest om te beginnen met de uitdagend IMAP lap. Ik dank jullie daarvoor.

Mw. Blokland-Woudenberg, lieve Magreet, jarenlang vormde jij met Bea SopacuaRoelofsen het secretariaat Plastische Chirurgie UMC Utrecht, het baken waarop wij allen zo vertrouwen. Vlak voor je pensioen werd je "geteisterd" door dit manuscript dat printklaar moest worden gemaakt. Hartelijk dank voor jouw inzet hierbij, dank ook voor de vele jaren van gezelligheid op het secretariaat. Geniet van het nieuwe leven! 
Assistenten Plastische Chirurgie i.o. en niet i.o. UMC Utrecht (Miriam, Sven, Paul, Eline, Wies, Eva en Mireille), jullie zijn een echt gezellige groep en zorgen er voor dat het "in de Academie" leuk blijft om te werken! Dank voor jullie zorg voor "de lappen". Extra dank aan Dalibor "Zotero" Vasilic voor de ICT ondersteuning en Paul "Down Under" van Minnen voor het doorlezen van het manuscript en de waardevolle adviezen in zaken promotie en sponsoring.

Oud-assistenten, oud- IMAP-gangers, dank voor jullie geduld bij de eerste schreden op het pad van deze nieuwe lap.

Drs. R.J.P.M. Franken, beste Ralph, paranimf, geprezen Bolletje-Pijltje navigator.

Samen begonnen in 1999, jij als assistent in opleiding, ik als jonge klare. Je vormde in die tijd, samen met Max Overgoor, een fantastisch koppel waar ik destijds veel steun aan heb gehad in de start van een reconstructieve carrière. Veel respect heb ik voor je hoe je uiteindelijk in Den Bosch een prachtige praktijk hebt opgebouwd.

Ik heb je weten te strikken voor de Commissie Kwaliteit van de NVPC, ik hoop dat je me dat niet meer kwalijk neemt. Onze gesprekken op weg naar een visitatie heb ik echter altijd wel gewaardeerd.

Dank dat je me terzijde wilt staan tijdens de verdediging, met jouw navigatiekunde moet het gaan lukken. Doen we ook nog eens een keer een rally-tje?

The "Monday-team" van EMC Bosch en Duin, dank voor jullie geduld met me als ik na een weekeinde typen weer stoom kwam afblazen.

Hemma Honders, kliniekmanager van het EMC maar ook tomeloze regelneef(of nicht?) achter de schermen, dank voor je inzet voor drukker en sponsoring en je luisterend oor in de afrondende fase van het proefschrift.

Tenslotte mijn zeer gewaardeerde Yvon van Leur, "personal assistant", kokkin van de maandagavond en trouwe vriendin. Dank voor het aanhoren van de promotie perikelen!

De " Multi-Media-gang" van het UMC Utrecht (Erik-Jan, Thomas en Roy) wil ik danken voor de prachtige foto's in dit proefschrift. Jullie zijn in staat geweest allerlei ge-iPhonede foto's op te pimpen tot toonbare plaatjes waardoor de series compleet zijn en nu het proefschrift sieren.

Thomas Dobber, fotograaf. Apple-Steve zou gewild hebben dat hij zo zou zijn geportretteerd! Dank voor de mooie coverfoto.

Ingrid Janssen wil ik danken voor de prachtige illustraties, deze vormen echt het bekende "toefie". 
Lieve familie en vrienden, jullie hebben jarenlang moeten aanhoren waar ik zoal in dat Academisch ziekenhuis mee bezig was. Begrijpelijk dat het jullie duizelde omtrent lappen en flappen, en dat het niet altijd duidelijk was waarover ik me zorgen maakte. Dank voor de belangstelling die jullie in mijn werk en proefschrift hebben getoond. En natuurlijk wil ik jullie danken voor het feit dat jullie het boekje van voor tot achter verslonden hebben!

Lieve schoonmoeder, dank voor Uw altijd oprechte belangstelling voor mijn werk, proefschrift en het wel en wee van ons gezin. Hoewel Uw zicht wat beperkter is geworden weet ik zeker dat $\mathrm{U}$ zult genieten. Hora est wordt trouwens luid aangekondigd...

Lieve Pa, heel veel dank voor het vele wat jij, samen met met ma in mij hebt geïnvesteerd. We konden immers destijd toch maar "gewoon" geneeskunde gaan studeren! Jammer dat mama deze promotie niet meer heeft mee gemaakt, ze zou natuurlijk apetrots zijn geweest. Hoop dat jouw gezondheid het toelaat om dit alles bij te kunnen wonen want ik weet zeker dat je er van zult genieten.

Lieve kinderen Schellekens, aan jullie ieder apart ben ik een dankwoord verschuldigd:

Lieve Julia, jij als echt "Stichts meisje" dacht natuurlijk dat promoveren betekende: meer geld verdienen. Helaas Juul, het kost alleen maar geld. Juist in de tijd dat jij geholpen wilde worden met wiskunde en Frans was papa in zijn hok. Toch ga je nu lekker naar de derde van het Atheneum en ik ben ongelofelijk trots je dat je het zo goed doet. Je bent en blijft (hopelijk) een voorbeeld-kind waar je als ouders er makkelijk tien van kunt hebben! Dank dat je begrip kon opbrengen dat papa zo vaak in zijn vrije tijd moest werken.

Lieve Stijn, jij als supersnelle spits van DOSC dacht dat promoveren betekende dat je dan in de Eredivisie mocht gaan opereren. Al snel werd het je duidelijk dat het betekende dat papa niet altijd tijd had om naar jouw wedstrijden te komen kijken. Maar op die keren dat ik er was heb ik ongelofelijk genoten van jouw voetbal-, waterpoloof judo-acties. Je gaat nu naar de middelbare school en papa heeft nu dan ook veel tijd over om jou door dat brugklas jaar heen te helpen. Ook op jou ben ik natuurlijk ongelofelijk trots! 
Lieve Tijmen, aan jou uitleggen wat promoveren betekent was een beetje lastig, jij dacht zelf dat dit betekende dat er meer mensen prikjes gingen krijgen. Promoveren betekende echter voor jou dat papa minder tijd had om gezamelijk te klussen, iets waar jij het meest voor warm loopt. Jij bent de "handy-man" van de familie, altijd met mijn gereedschap in de weer hetgeen dan ook vaak spoorloos verdwenen is. Wat zou het leuk zijn geweest als jij plastisch chirurg had kunnen worden.... Hou van jou.

En tenslotte mijn lieve Ellen. De afspraak was dat het dankwoord niet te "klef" zou worden echter je verwachte toch minimaal een hele pagina. Dat ik de reconstructieve kant van het vak zo aantrekkelijk vond kon je in het begin van de carrière niet altijd begrijpen. "Ga toch gewoon oogleden doen" waren jouw woorden als ik vaak moe en soms bezorgd laat thuis kwam na een hoofd-hals reconstructie. Echter je zorgde altijd voor een bordje warm eten in de magnetron. Later begreep je goed waar mijn passie lag en dat de zorg om de patiënten zich ook buiten dienst tijden om uitstrekte. Even snel naar het ziekenhuis om te kijken of patiënt en lap goed gingen heb je altijd zonder morren geaccepteerd.

Met de start van de promotie kwamen de zorgen van het gezinsleven meer op jouw schouders te liggen. Ik heb erg heel veel bewondering en respect voor de manier waarop jij dit alles hebt gedragen. Zonder jouw inzet voor de "normale" zorgen was het niet gelukt. Ik ben je ontzettend dankbaar voor de mogelijkheid die ik heb gekregen om het proefschrift tot een goed einde te brengen. Laten we de titel gewoon delen, ik de $D$, jij de $R$, of andersom, dat heb je absoluut verdiend.

Mijn enige wens is om samen met jou, in goede gezondheid oud te worden en al die jaren van de kinderen te kunnen genieten. Want daar kan tenslotte niets tegen op......

Quod scripsi, scriptum est

Pascal Schellekens, juni 2012 
Chapter 9 


\section{Curriculum Vitae}

Pascal Schellekens werd op 9 maart 1962 geboren te Eindhoven. Het VWO diploma werd behaald aan het Van Maerlantlyceum te Eindhoven in 1981. Na aanvankelijke start met de opleiding fysiotherapie werd in 1983 begonnen met de studie geneeskunde aan de Katholieke Universiteit Nijmegen. In 1987 werd cum laude het doctoraal examen gehaald gevolgd door het arts-examen in 1991. Als assistent Plastische chirurgie niet-in-opleiding heeft hij gewerkt bij de maatschap Plastische Chirurgie te Eindhoven van 1991 tot april 1992. Daarna werd hij AGNIO op de afdeling Plastische Chirurgie Academisch Ziekenhuis Utrecht waarna in januari 1993 werd gestart met de drie-jarige vooropleiding heelkunde in het Rijnstate ziekenhuis te Arnhem (opleider dr. W.F. Eggink). In januari 1996 werd gestart met de vervolgopleiding Plastische Chirurgie bij de afdeling Plastische, Reconstructieve en Handchirurgie van het Academisch Ziekenhuis Utrecht (opleider Prof Dr. M.Kon).

Sedert januari 1999 is hij werkzaam als staflid bij het Universitair Medisch Centrum Utecht met als aandachtsgebied de reconstructieve (micro)chirurgie, peri-orbitale chirurgie en esthetische chirurgie.

Verdere werkzaamheden zijn gelegen in het Esthetisch Medisch Centrum Bosch en Duin en ziekenhuis Rivierenland te Tiel. Verder is hij lid van de Commissie Kwaliteit van de Nederlandse Vereniging voor Plastische Chirurgie.

Pascal is getrouwd met Ellen Schellekens-de Bruin en zij hebben drie kinderen, Julia, Stijn en Tijmen. 
